\title{
WATER RESOURCES OF SEDGWICK COUNTY, KANSAS
}

By Hugh E. Bevans

U.S. GEOLOGICAL SURVEY

Water-Resources Investigations Report 88-4225

Prepared in cooperation with

SEDGWICK COUNTY and the CITY OF WICHITA

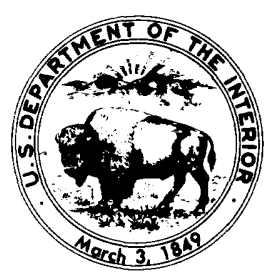

Lawrence, Kansas

1989 


\section{DEPARTMENT OF THE IN'TERIOR \\ MANUEL LUJAN, JR., Secretary \\ U.S. GEOLOGICAL SURVEY \\ Dallas L. Peck, Director}

For additional information write to:

\section{District Chief}

U.S. Geological Survey

Water Resources Division

4821 Quail Crest Place

Lawrence, Kansas 66049
Copies of this report can be purchased from:

U.S. Geological Survey

Books and Open-File Reports

Denver Federal Center

Box 25425, Building 810

Denver, Colorado 80225 


\section{CONTENTS--Continued}

Figure

9. Graph showing flow-duration curves for North Fork Ninnescah River above Cheney Reservoir and at Cheney Dam, South Fork Ninnescah River near Murdock, and Ninnescah River near Peck, October 1965-September 1985

10. Graphs showing low-flow frequency curves for Arkansas River near Hutchinson, at Wichita, and at Derby; and for Little Arkansas River at Valley Center, October 1965September 1985

11. Graphs showing low-flow frequency curves for North Fork Ninnescah River above Cheney Reservoir, South Fork Ninnescah River near Murdock, and Ninnescah River near Peck, October 1965-September 1985

12. Graphs showing high-flow frequency curves for Arkansas River near Hutchinson, at Wichita, and at Derby; and for Little Arkansas River at Valley Center, October 1965-

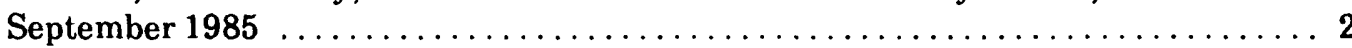

13. Graphs showing high-flow frequency curves for North Fork Ninnescah River above Cheney Reservoir, South Fork Ninnescah River near Murdock, and Ninnescah River near Peck, October 1965- September 1985

14. Sketch illustrating method used to describe location of sampling sites $\ldots \ldots \ldots 52$

15. Graph showing storage-yield curves for Little Arkansas River at Valley Center, North Fork Ninnescah River near Cheney, and South Fork Ninnescah River near Murdock, representing a 2-percent chance of deficiency $\ldots \ldots \ldots \ldots \ldots \ldots \ldots \ldots \ldots \ldots \ldots \ldots \ldots \ldots \ldots$

16. Graph showing regional storage-yield curves for unregulated streams with drainage areas less than 300 square miles, representing a 2-percent chance of deficiency ... 58

17. Map showing mean annual runoff in eastern Kansas $\ldots \ldots \ldots \ldots \ldots \ldots \ldots$

18. Hydrographs of selected wells in Sedgwick County and graphs showing seasonal precipitation at Wichita, irrigated acres in Sedgwick County, and annual groundwater withdrawals from Wichita well field, 1938-85, and cumulative departure from average precipitation $(1888-1985)$ at Wichita $\ldots \ldots \ldots \ldots \ldots \ldots \ldots \ldots \ldots \ldots$

19. Map showing saturated thickness of unconsolidated deposits in Sedgwick County . 81

20. Map showing Wichita well field in southwest Harvey and northwest Sedgwick Counties, public-supply and observation-well network, and water-level declines from August 30, 1940 to March 31, 1960, and from August 30, 1940 to October 1, 1982

21. Graph showing chloride concentrations in adjacent wells indicating downward movement of brine from shallow evaporation pits in vicinity of Wichita well field, 1939-83106

22. Map showing chloride concentrations in vicinity of Wichita well field, 1980-85 . 107 


\section{CONTENTS--Continued}

1. Estimated water use in Sedgwick County during 1985 and 1984 appropriated water rights

2. Selected water-quality criteria for water used as sources of public- and domestic-water

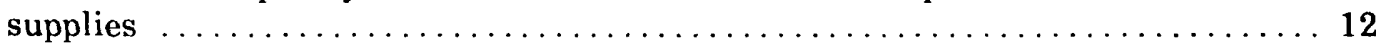

3. Water-quality characteristics of water resources that have been used as sources for

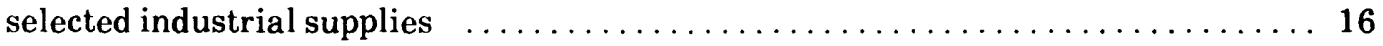

4. Permissible number of irrigations with saline water in humid regions between leaching

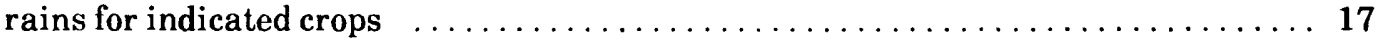

5. Criteria for maximum values of selected water-quality properties and constituents in

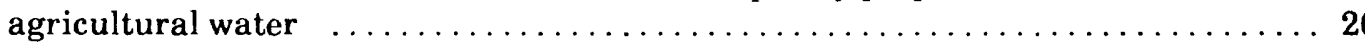

6. Statistical summary of selected water-quality properties and constituents for major

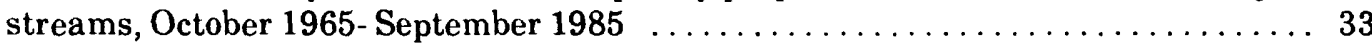

7. Results of correlation and regression analysis relating selected water-quality properties and constituents to streamflow for major streams, October 1965September 1985

8. Results of correlation and regression analysis relating discharge of sodium, sulfate, chloride, dissolved solids, and suspended sediment to streamflow for major streams, October 1965- September 1985

9. Computation of mean suspended-sediment discharge for Arkansas River near Hutchinson, October 1965- September 1985

10. Mean annual discharge of dissolved solids and suspended sediment for major streams,

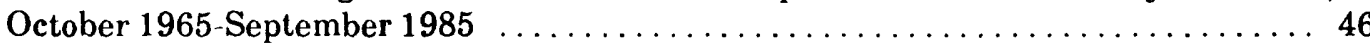

11. Streamflow and water-quality data collected during a low-flow reconnaissance in

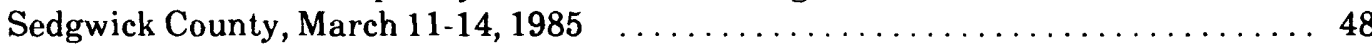

12. Water-quality data for selected impoundments in Sedgwick County, October 21-

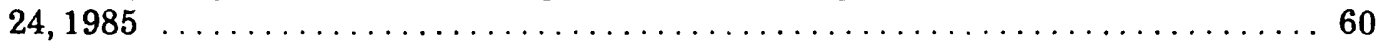

13. Mean values of selected properties and concentrations of chemical constituents in water

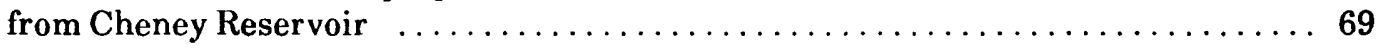

14. Records of wells where water-level measurements were made during December 1985 and January 1986

15. Water-quality data for selected wells in Sedgwick County, August 1985 and February 1986

16. Statistical summary of water-quality data from selected wells in Sedgwick County

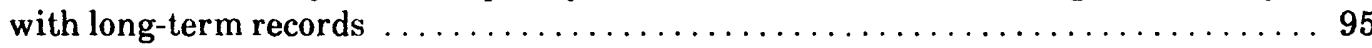




\section{CONTENTS}

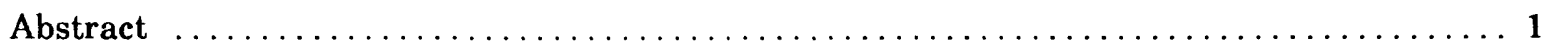

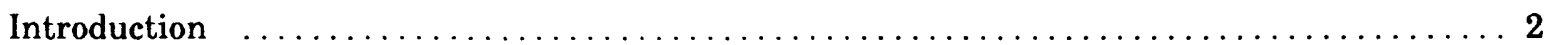

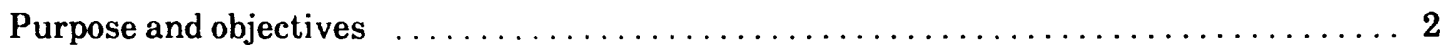

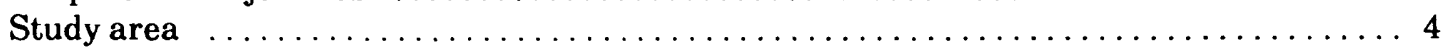

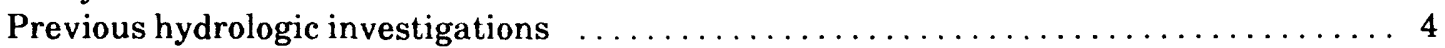

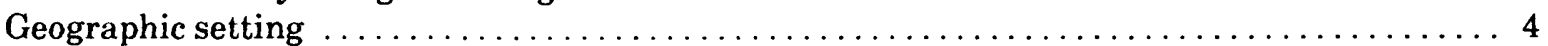

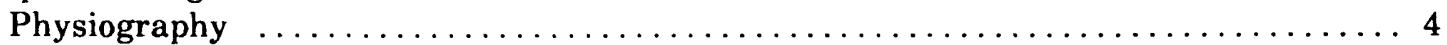

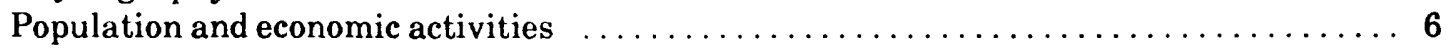

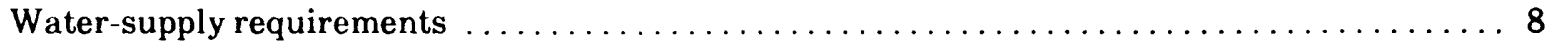

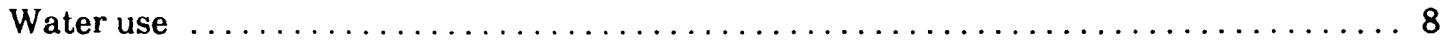

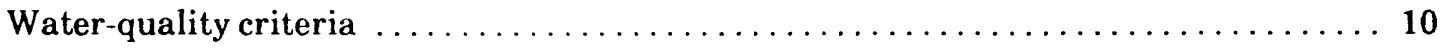

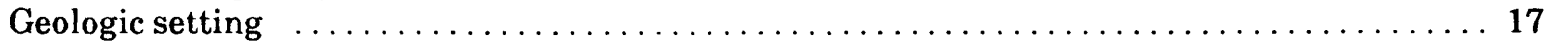

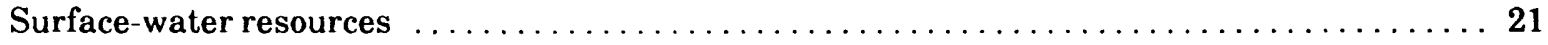

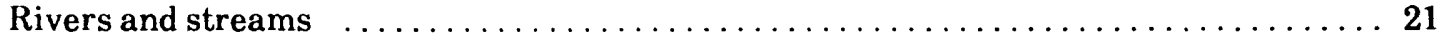

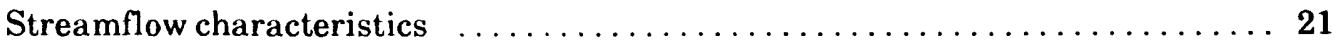

Historic streamflow .................................. 21

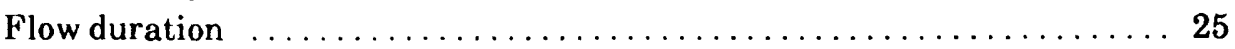

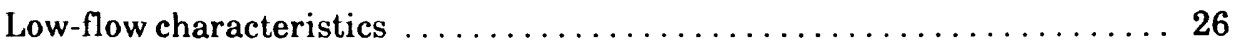

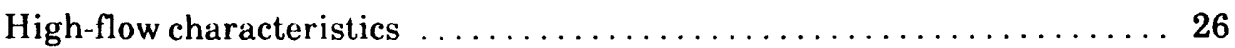

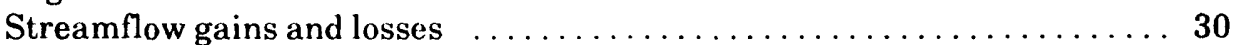

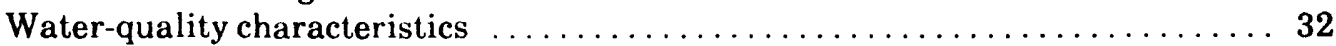

Statistical summary of water-quality properties and constituents $\ldots \ldots 32$

Relationships between streamflow and water-quality properties and

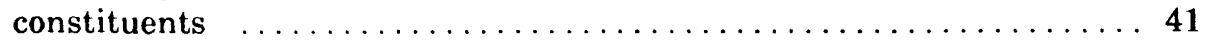

Discharge of sodium, sulfate, chloride, dissolved solids, and suspended

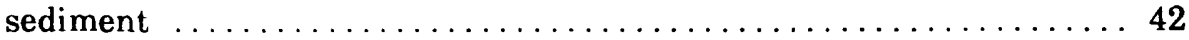

Results of low-flow water-quality reconnaissance $\ldots \ldots \ldots \ldots \ldots \ldots 47$

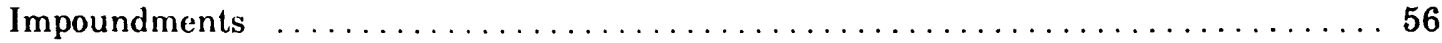

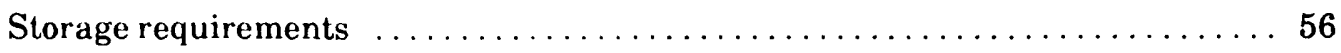

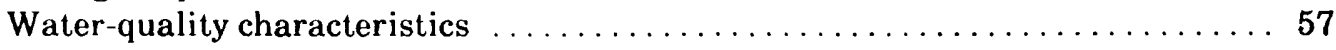

Results of water-quality reconnaissance $\ldots \ldots \ldots \ldots \ldots \ldots \ldots \ldots$

Estimated water-quality characteristics of hypothetical impoundments on

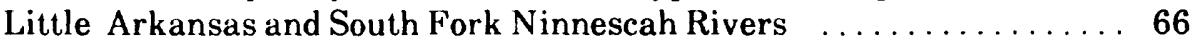

Cheney Reservoir . . . . . . . . . . . . . . . . . . . . . . . . . . . . . . 67

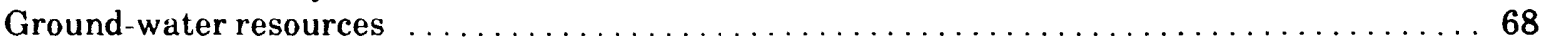

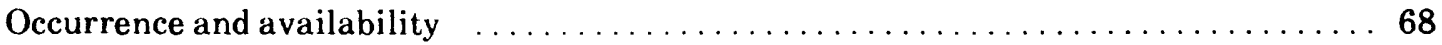

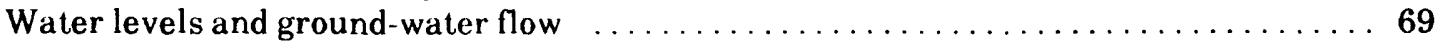

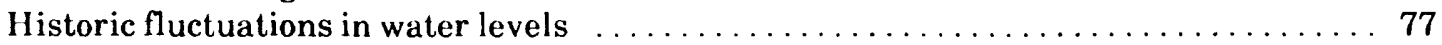

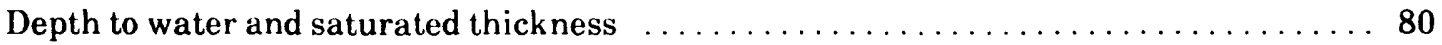

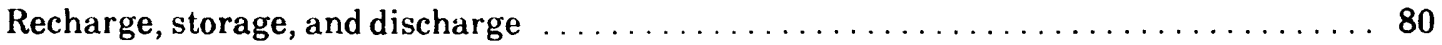

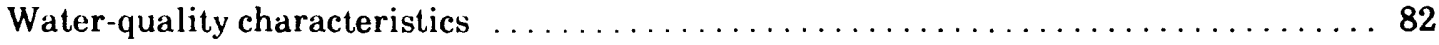

Relationship between ground-water quality and geology $\ldots \ldots \ldots \ldots \ldots \ldots .82$

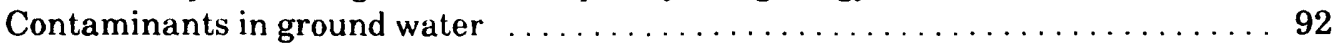

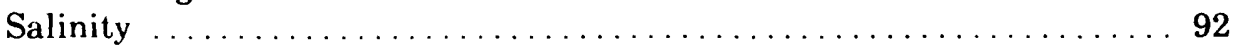

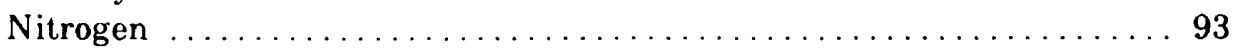

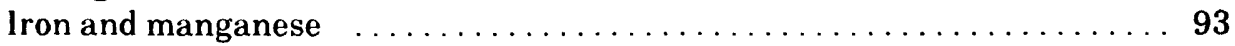

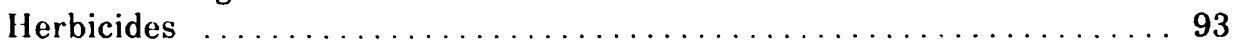

Volatile organic compounds ........................ 94

Statistical summary of historic water-quality data for selected wells $\ldots \ldots \ldots \ldots 94$

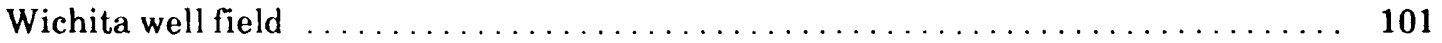




\section{CONTENTS--Continued}

Ground-water resources--Continued

Wichita well field--Continued

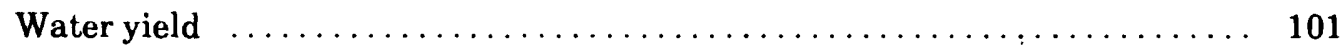

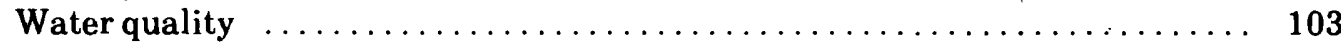

Stream-aquifer interaction in Arkansas and Little Arkansas River basins near Wichita $\quad \ldots \quad 107$

Rationale for evaluating stream-aquifer interaction $\ldots \ldots \ldots \ldots \ldots \ldots \ldots \ldots \ldots$

Definition of selected ground-water terms $\ldots \ldots \ldots \ldots \ldots \ldots \ldots \ldots \ldots \ldots \ldots \ldots$

Relationship between stream-aquifer interaction and base-flow recession $\ldots \ldots \ldots, 108$

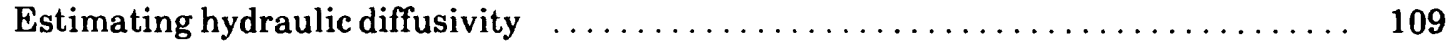

Determining slope of base-flow recession $\ldots \ldots \ldots \ldots \ldots \ldots \ldots \ldots \ldots \ldots, 109$

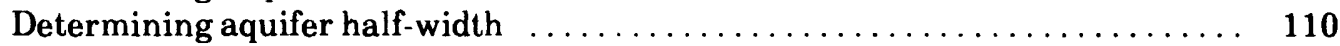

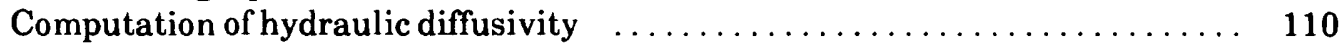

Comparison of stream-aquifer properties with aquifer properties determined by

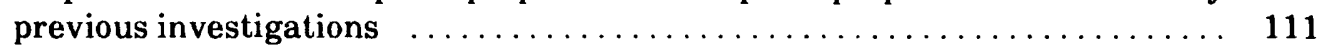

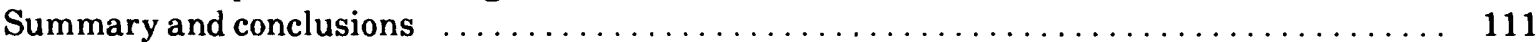

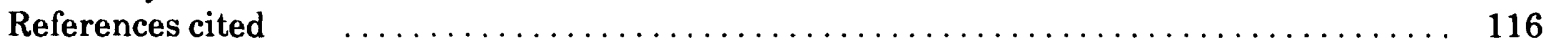

\section{ILLUSTRATIONS}

Plate

1. Map showing concentration of dissolved solids and chemical composition of ground and surface water in Sedgwick County, Kansas, 1985-86 (in pocket)

2. Map showing ground-water levels and depths to water in Sedgwick County, Kansas

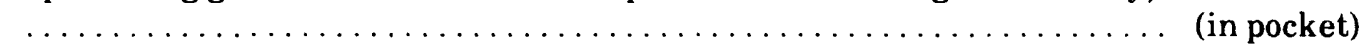

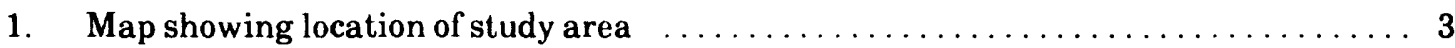

2. Map showing physiographic provinces of Kansas $\ldots \ldots \ldots \ldots \ldots \ldots \ldots \ldots$

3. Graph showing average monthly precipitation and temperature at Wichita, 1888-19856

4. Graph showing population in Sedgwick County, $1920-80 \ldots \ldots \ldots \ldots \ldots \ldots \ldots$

5. Map showing distribution of 1984 appropriated water rights in Sedgwick County _. 9

6. Map showing surface geology and selected geologic cross sections in Sedgwick County 18

7. Graphs showing average seasonal streamflow (1938-85) and cumulative departure from average streamflow (during indicated period of record) for Little Arkansas River at Valley Center (1922-85), Arkansas River at Wichita (1934-85), and Ninnescah River near Peck (1938-85), and seasonal precipitation (1938-85) and cumulative departure from average precipitation $(1888-1985)$ at Wichita $\ldots \ldots \ldots \ldots \ldots \ldots \ldots 22$

8. Graph showing flow-duration curves for Arkansas River near Hutchinson, at Wichita, and at Derby; and for Little Arkansas River at Valley Center, October 1965-

September 1985 


\section{CONTENTS--Continued}

Table

Page

17. Water-quality data for wells in vicinity of Wichita well field, $1980-85 \ldots \ldots \ldots$. $\ldots 4$

18. Values of transmissivity, storage coefficient, and hydraulic diffusivity for unconsolidated aquifers of the Arkansas and Little Arkansas Rivers in Reno, Harvey, and Sedgwick Counties, compiled from previous investigations $\ldots \ldots \ldots \ldots \ldots \ldots .112$

\section{CONVERSION FACTORS}

Inch-pound units of measurements used in this report may be converted to metric (International System) units using the following conversion factors:

Multiply inch-pound unit

inch

inch per year

foot

foot per mile

mile

mile per hour

square mile

cubic foot

acre

acre-foot

gallon

gallon per minute

cubic foot per second

ton

ton per day

ton per square mile

cubic foot per second

per square mile

acre-foot per square mile

foot squared per day

pound per cubic foot

degrees Fahrenheit $\left({ }^{\circ} \mathrm{F}\right)$
By

25.4

25.4

0.3048

0.1894

1.609

1.609

2.590

0.02832

0.4047

1,233

3.785

0.06309

0.02832

0.9072

0.9072

0.3502

0.1093

476.06

0.0929

16.02

(1)
To obtain metric unit

millimeter

millimeter per year

meter

meter per kilometer

kilometer

kilometer per hour

square kilometer

cubic meter

hectare

cubic meter

liter

liter per second

cubic meter per second

megagram

megagram per day

megagram per square kilometer

cubic meter per second

per square kilometer

cubic meter per square kilometer

meter squared per day

kilogram per cubic meter

degrees Celsius $\left({ }^{\circ} \mathrm{C}\right)$

${ }^{1} \mathrm{C}=5 / 9 \times\left({ }^{\circ} \mathrm{F}-32\right)$.

Sea level: In this report, "sea level" refers to the National Geodetic Vertical Datum of 1929--a geodetic datum derived from a general adjustment of the first-order level nets of both the United States and Canada, formerly called "Mean Sea Level ." 


\title{
WATER RESOURCES IN SEDGWICK COUNTY, KANSAS
}

\author{
By Hugh E. Bevans
}

\begin{abstract}
The large population and diverse economic activities in Sedgwick County and its principal city, Wichita, require adequate water supplies for public, domestic, irrigation, and industrial uses. This report documents the current (1986) quantity and quality characteristics of surface- and ground-water resources, describes causes and extent of detected changes in water-resource characteristics, and evaluates water resources with respect to water-supply requirements. Interpretations of water-quality data collected from 52 stream sites, 14 impoundments, and 101 wells; of water-level measurements made at 335 wells; of historic or long-term streamflow and water-quality data from U.S. Geological Survey streamflow-gaging stations; and of water-level and water-quality data from monitoring wells were used in conjunction with results of previous investigations.
\end{abstract}

During 1985, an estimated 134,200 acrefeet of water ( 84 percent ground water) were used for public supplies (42 percent), irrigation (40 percent), self-supplied industrial use (14 percent), and self-supplied domestic use (4 percent). The city of Wichita used about 53,500 acre-feet of water for public supplies.

Streamflow is closely related to precipitation, and major streams are sustained by ground-water inflow. Cheney Reservoir on the North Fork Ninnescah River near Cheney, Kansas, has decreased flow downstream in the North Fork Ninnescah and the Ninnescah Rivers. The Arkansas River is in approximate equilibrium with ground water in the valley-fill deposits north of Wichita but becomes a gaining stream at Wichita. The Little Arkansas and Ninnescah Rivers are gaining streams through Sedgwick County.

Water in the Arkansas River is a sodium chloride type, with a median dissolved-solids concentration of 1,700 milligrams per liter at Hutchinson and 1,200 milligrams per liter at
Derby. The Little Arkansas River at Valley Center has a calcium bicarbonate type water, with a median dissolved-solids concentration of $\mathbf{4 8 0}$ milligrams per liter. Water in the Ninnescah River is a sodium chloride type, with median dissolved-solids concentrations ranging from 640 milligrams per liter in the Ninnescah River near Peck to 760 milligrams per liter in the South fork Ninnescah River near Murdock. The source of sodium and chloride in the Arkansas and Ninnescah Rivers is saline ground water discharged from Permian rocks upstream of Sedgwick County.

The Arkansas River basin upstream of Hutchinson has the smallest annual rates of chemical erosion ( 16.8 tons dissolved solids per square mile) and physical erosion (12.8 tons suspended sediment per square mile), while the South Fork Ninnescah River basin has the greatest annual rate of chemical erosion (206 tons dissolved solids per square mile) and the Little Arkansas River basin has the greatest annual rate of physical erosion (239 tons suspended sediment per square mile).

Small streams draining the county generally have water-quality characteristics that reflect the geochemical properties of aquifers providing base flow. Streams draining the Wellington formation often have calcium sulfate type water, with concentrations of dissolved solids commonly exceeding 1,000 milligrams per liter. Streams draining the Ninnescah Shale usually have calcium bicarbonate type water, with less than 1,000 milligrams per liter dissolved solids. Streams draining unconsolidated deposits generally have a calcium bicarbonate type water, with less than 500 milligrams per liter dissolved solids.

Contamination of streams by sewagetreatment-plant effluent was indicated by increased ammonia concentrations in the Arkansas River at Derby and Mulvane, in the Little Arkansas River near Sedgwick, and in Cowskin Creek near Maize and at the Sumner County line. Contamination by oilfield brine 
was detected in the Wichita-Valley Center floodway near Haysville, in Prairie Creek 4 miles southeast of Furley, and in Whitewater Creek at the Butler County line.

Agricultural pesticides (atrazine, cyanazine, and propazine) or the pesticide residue, heptachlor epoxide, were detected in 8 of 14 impoundments. An impoundment on the Little Arkansas River at Valley Center would have water with an estimated mean dissolved-solids concentration of about 220 milligrams per liter and would lose from 160 to 310 acre-feet of storage each year due to sedimentation. An impoundment on the South Fork Ninnescah River would have an estimated mean dissolvedsolids concentration of 560 milligrams per liter and would lose from 59 to 110 acre-feet of storage each year due to sedimentation.

Ground water occurs in rocks throughout the area, but unconsolidated deposits of the Arkansas River valley are the principal aquifer. Wells in these unconsolidated deposits yield as much as 2,000 gallons per minute of water that generally is a calcium bicarbonate type, with less than $\mathbf{5 0 0}$ milligrams per liter dissolved solids; however, adjacent to the Arkansas River north of Wichita, sodium chloride type water with more than 1,000 milligrams per liter dissolved solids occurs. Wells in the Wellington Formation typically yield from 10 to $\mathbf{3 5 0}$ gallons per minute of calcium sulfate type water, with more than 1,000 milligrams per liter dissolved solids. Wells in the Ninnescah Shale generally yield less than 10 gallons per minute of calcium bicarbonate type water, with less than 1,000 milligrams per liter dissolved solids. Ground-water levels are closely related to cumulative departure from average precipitation; however, cones of depression have developed in local areas where large volumes of ground water are withdrawn for public or industrial supplies, especially in the Wichita well field where local declines greater than 25 feet have occurred.

Ground-water contamination by oilfield brines was indicated in 16 of 101 sampled wells. Nitrite-plus-nitrate as nitrogen concentrations exceeded 10 milligrams per liter in water from 11 of 101 sampled wells. Iron concentrations exceeded 300 micrograms per liter in water from 18 of 101 wells, and manganese concentrations exceeded 50 micrograms per liter in water from 31 of 101 wells. Herbicides (atrazine, metolachlor, propazine, and simizine) were detected in water from 5 of 19 wells, and a volatile organic compound (trichloroethylene) was detected in water from 1 of 10 wells.

Analysis of base-flow recession curves, used to estimate stream-aquifer interaction in the Arkansas and Little Arkansas River valleys, indicated hydraulic diffusivities of $1.6 \times 10^{6}$ feet squared per day in the Arkansas River valley and $2.2 \times 10^{6}$ feet squared per day in the Little Arkansas River valley.

\section{INTRODUCTION}

\section{Purpose and Objectives}

The large population and diverse economic activities in Sedgwick County and the city of Wichita require adequate water supplies for public, domestic, irrigation, and industrial uses. Water-resource management in the area has been based primarily on information contained in reports of hydrologic investigations that were published more than 20 years ago--(1) Water Resources of the Wichita Area, Kansas (Petri and others, 1964) and (2) Geohydrology of Sedgwick County, Kansas (Lane and Miller, 1965a,b). To ensure that adequate water supplies will be available in the future, current hydrologic and related information are needed for developing management strategies. In response to the need for current hydrologic information, the U.S. Geological Survey, in cooperation with Sedgwick County and the city of Wichita, conducted an investigation of areal water resources during 1984-86. The investigation provided data and interpretation needed to meet three principal objectives:

(1) Document the current quantity and quality characteristics of surfaceand ground-water resources,

(2) describe causes and extent of observed changes in water-resource characteristics, and 


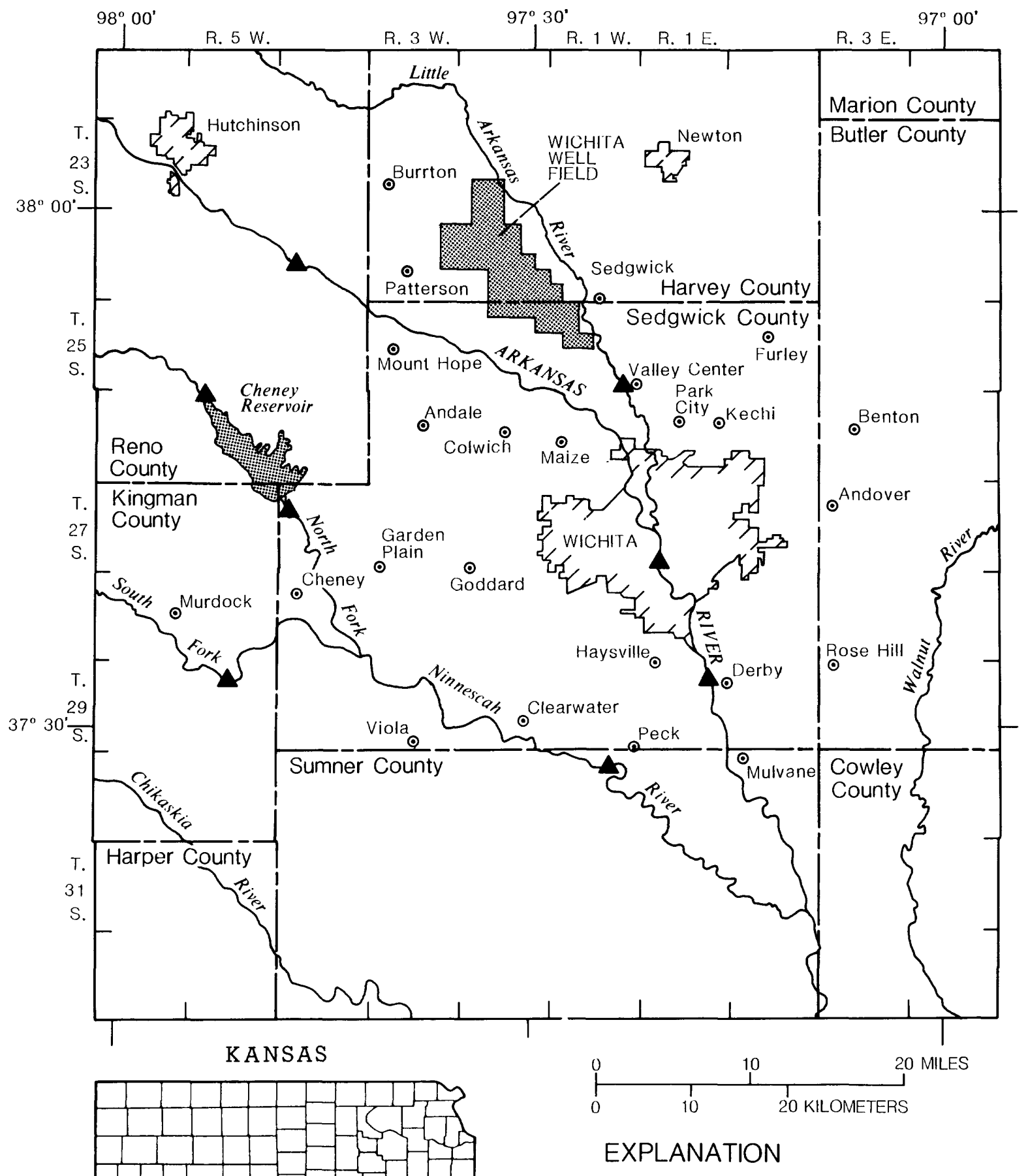

- U.S. GeOlogical SuRVEy

STREAMFLOW-GAGING STATION

Figure 1. Location of study area. 


\section{Study Area}

The study area is located in south-central Kansas and includes the city of Wichita, Sedgwick County, and adjacent areas (fig. 1). The Arkansas River and its tributary streams, including the Little Arkansas and Ninnescah Rivers, constitute the primary surface-water drainage system in the area. The eastern edge of the area is drained by east-flowing tributaries to the Walnut River in Butler County. The Wichita well field, located primarily in southwest Harvey County, and Cheney Reservoir in southeast Reno County are the principal sources of public-water supplies for Wichita, suburban areas east of Wichita, improvement districts in or adjacent to Wichita (Eastborough ,Oaklawn, and Sunview), Kechi, Park City, Rural Water Districts 1 and 2, and small towns in western Butler County (Andover, Benton, and Rose Hill) (Lorenz and others, 1985).

\section{Previous Hydrologic Investigations}

The importance of and concern about water resources in the study area are evidenced by numerous reports that have been published during the past 75 years covering a variety of hydrologic topics. Early investigations were based on very limited data and provided only brief descriptions of ground- and surface-water quality (Parker, 1911) and well yields and quality of water available for irrigation supplies (Meinzer, 1914).

Results of an investigation of the geology and ground-water resources of the Equus beds, the principal aquifer in the area, (Lohman and Frye, 1940) led to the location of the present Wichita well field, which is west of the Little Arkansas River in southwest Harvey County and northwest Sedgwick County (fig. 1). An estimate of ground water available for pumping from the Wichita well field was subsequently developed (Williams and Lohman, 1947). In concluding their hydrologic studies in the area, Williams and Lohman authored a comprehensive report about the geology and ground-water resources of south-central Kansas that included discussions of the Wichita well field (Williams and Lohman, 1949). Progress was made in defining the ground-water hydrology of the Equus beds (Stramel, 1956; $1962 \mathrm{a} ; 1967)$, and a preliminary assessment was made of the potential for artificial ground-water recharge in the vicinity of the Wichita well field (Stramel, 1962b).

Emergency water supplies that could be utilized in the event of nuclear or biological warfare were evaluated by Lane and others (1962). Petri and others (1964) evaluated the ground-and surface-water resources of the Wichita area with respect to industrial-supply requirements.

A comprehensive report describing the geohydrology, including both availability and quality of ground water from geologic formations in Sedgwick County, was written by Lane and Miller (1965a). Logs of 369 wells and test holes used to develop interpretations for the comprehensive report were presented in a separate publication (Lane and Miller, 1965b).

Flood studies have been conducted for the Arkansas River and its tributaries (Ellis and others, 1963) and for urbanized basins in Wichita (James, 1967; Richards, 1971; Peek and Jordan, 1978; Perry and Hart, 1984). Several investigations have dealt with saline-water problems in the area (Leonard and Kleinschmidt, 1976; Gogel, 1981; Hathaway and others, 1981; Engineering Enterprises, Inc., 1982; Whittemore, 1982; Whittemore and Basel, 1982; Whittemore, 1984).

The advent of the computer has led to the development of numerical models to simulate ground-water flow (Green and Pogge, 1977) and both ground-water flow and solute transport in the Equus beds (Sophocleous, 1983; Spinazola and others, 1985). The application of groundwater models underscored the need for accurate estimates of aquifer characteristics (Richards and Dunaway, 1972; Reed and Burnett, 1985; Sophocleous and Perry, 1985).

\section{GEOGRAPHIC SETTING}

\section{Physiography}

Sedgwick County is located at the western edge of the Central Lowland physiographic province (Schoewe, 1949) (fig. 2). That part of the area drained by the Arkansas River and its tributaries, including the Ninnescah River, is included in the Arkansas River Lowlands section 
of the Central Lowland. The Arkansas River Lowlands section is divided into the Great Bend Lowland and the Wellington Lowland. The Great Bend Lowland includes that part of the area that is drained by the Arkansas and Little Arkansas Rivers and is described as a flat, smooth plain, with local relief ranging from 0 to 300 feet (Hammond, 1964). The Wellington Lowland includes that part of the area drained by the Ninnescah River and is described as an irregular plain, with local relief ranging from 100 to 300 feet.

The eastern edge of the county, which is drained by tributaries to the Walnut River, is included in the Osage Plains section of the Central Lowland province. This area is on the western edge of the Flint Hills Upland, the western subdivision of the Osage Plains, and is described as an irregular plain with local relief ranging from 100 to 300 feet.

The highest point in the county is in township 26 south, range 3 west, section 31 (about 5 miles southwest of Andale), with an altitude exceeding 1,545 feet above sea level. The lowest point is in township 29 south, range 1 east, section 36, where the Arkansas River flows out of the county, with an altitude of less than 1,220 feet above sea level.

The climate of an area can be expressed in terms of long-term averages of meteorologic factors; the most important factors are temperature, wind, precipitation, and evapotranspiration. Because Sedgwick County is located in the central United States, it has a continental climate and is subject to large variations in temperature because it is far away from the moderating effect of oceans. The average annual temperature at Wichita during 1888 through 1985 was $56.3^{\circ} \mathrm{F}$, according to records of the National Oceanic and Atmospheric Administration (1888-1985). Average monthly temperatures (fig. 3) range from $29.6{ }^{\circ} \mathrm{F}$ in January to $81.4{ }^{\circ} \mathrm{F}$ in July. The growing season (freeze-free period) usually exceeds 190 days. Average annual wind speeds are among the greatest in the United States, exceeding 12 miles per hour (Eagleman, 1973). The wind direction is predominantly from the south during all seasons except winter, when it is predominantly from the north.

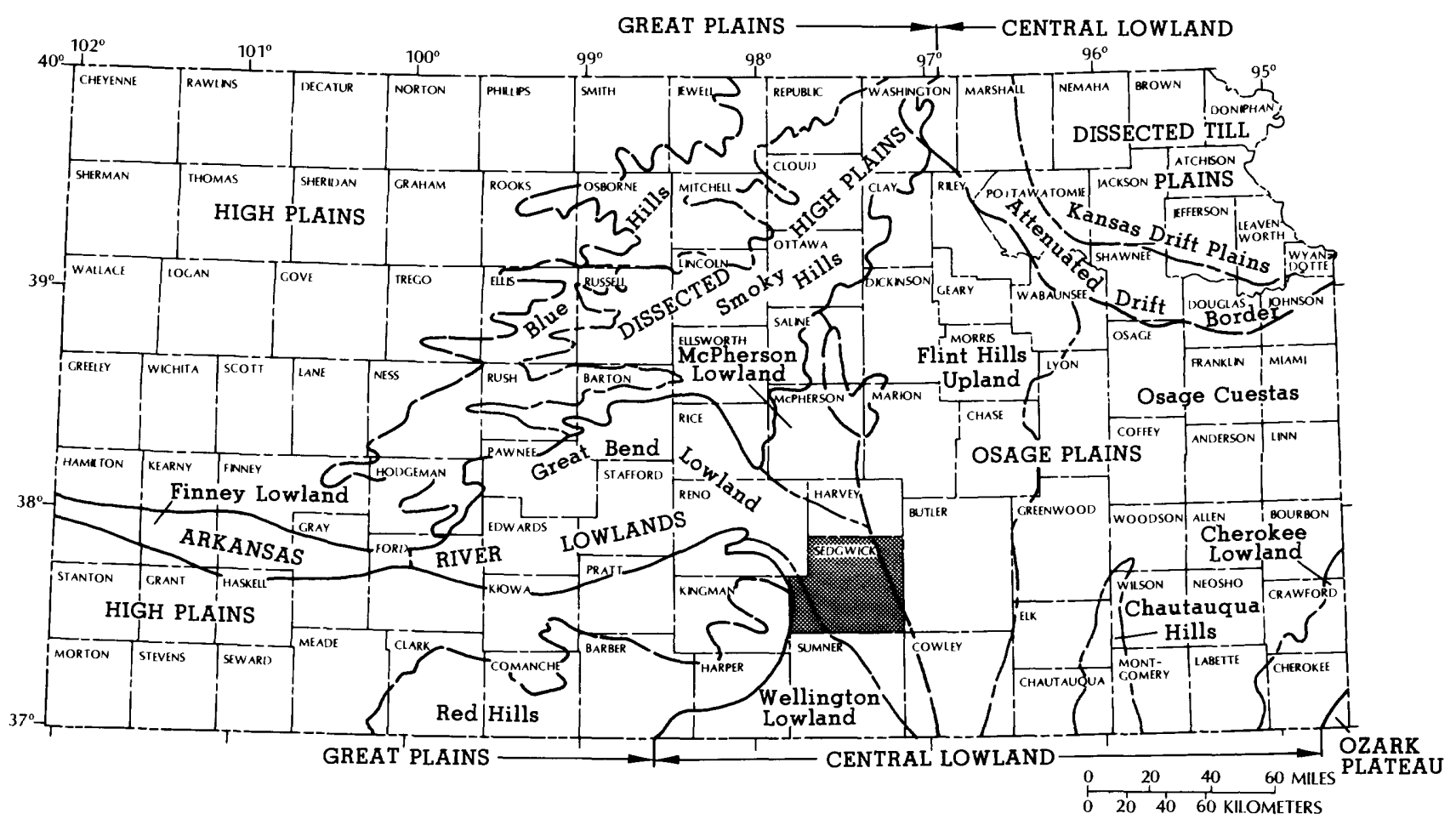

Figure 2. Physiographic provinces of Kansas (modified from Schoewe, 1949). 


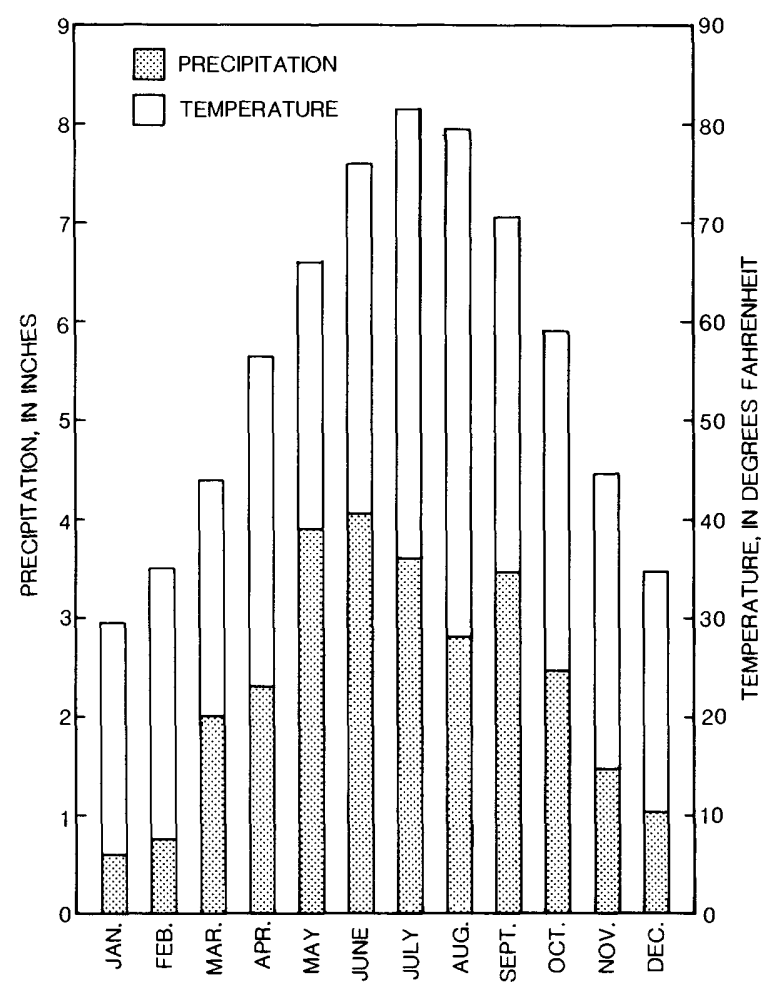

Figure 3. Average monthly precipitation and temperature at Wichita, 1888-1985.

The primary source of precipitation in the area is moisture-laden air from the Gulf of Mexico. The average annual precipitation at Wichita during 1888 through 1985 was 28.6 inches (data from National Oceanic and Atmospheric Administration, 1888-1985). Average monthly precipitation ranges from 0.68 inch in January to 4.06 inches in June (fig. 3). Most of the precipitation occurs as rain during the growing season (April through September).

Evapotranspiration, the sum of evaporation and transpiration by plants, is a function of meteorologic factors (temperature, humidity, and wind speed), soil moisture, and vegetation. During the growing season, transpiration is a major component of evapotranspiration, but during the nongrowing season transpiration ceases or is minimal. Evapotranspiration in the area ranges from 25 to 30 inches per year (Eagleman, 1973). The maximum rate of ground-water loss to evapotranspiration in the area was estimated to be 3.5 inches per year; however, this generally occurs only where the water table is within $\mathbf{1 0}$ feet of the land surface (Spinazola and others, 1985). Droughts can occur at any time but are most severe during the summer when evapotranspiration rates are greatest.

Soils in the county belong to the soil order Mollisol (U.S. Soil Conservation Service, 1967). Mollisols are some of the most productive agricultural soils in the world and are characterized by a surface horizon that is thick, dark, rich in organic material, dominated by divalent cations (calcium, $\mathrm{Ca}^{++}$, and magnesium, $\mathrm{Mg}^{++}$). Mollisols have a granular or crumb structure and are not hard when dry (Brady, 1974). Mollisols in the Arkansas River valley belong to the suborder Udoll, which is usually moist and has no horizons in which either gypsum or calcium carbonate has accumulated. Upland soil belongs to the suborder Ustoll, which is intermittently dry during the warm part of the year or has subsurface horizons in which salt or carbonate has accumulated. A soil survey of Sedgwick County was published by the U.S. Department of Agriculture, Soil Conservation Service (Penner and Wehmueller, 1979). The survey contains detailed soil maps, information about the use and management of soil, and information about engineering properties, physical and chemical properties, and soil and water features.

\section{Population and Economic Activities}

Sedgwick County had a population of 367,088 in 1980 , making it the most populated county in Kansas (Murray, 1985). Wichita, with a 1980 population of 288,723 , is the largest city in the State. Population in Sedgwick County during $1920-80$ is shown in figure 4 . During this period, the rural population has experienced slow but steady growth that has caused it to approximately double from 20,015 to 40,921 . The urban population has increased by a factor of approximately 4.5 , from 72,219 to 325,610 during the same period. The largest increase in county population occurred from 1940 to 1960 , when the population increased by almost 200,000 . Nearly all of this increase was due to a rapid increase in urban population that resulted from expansion of industries during World War II and the subsequent "baby boom" that followed the war. Since 1960, the rate of increase in urban population has moderated significantly and has been nearly equivalent to the increase in rural population. The 1990 county population is projected to be nearly 430,000 (Murray, 1985). 


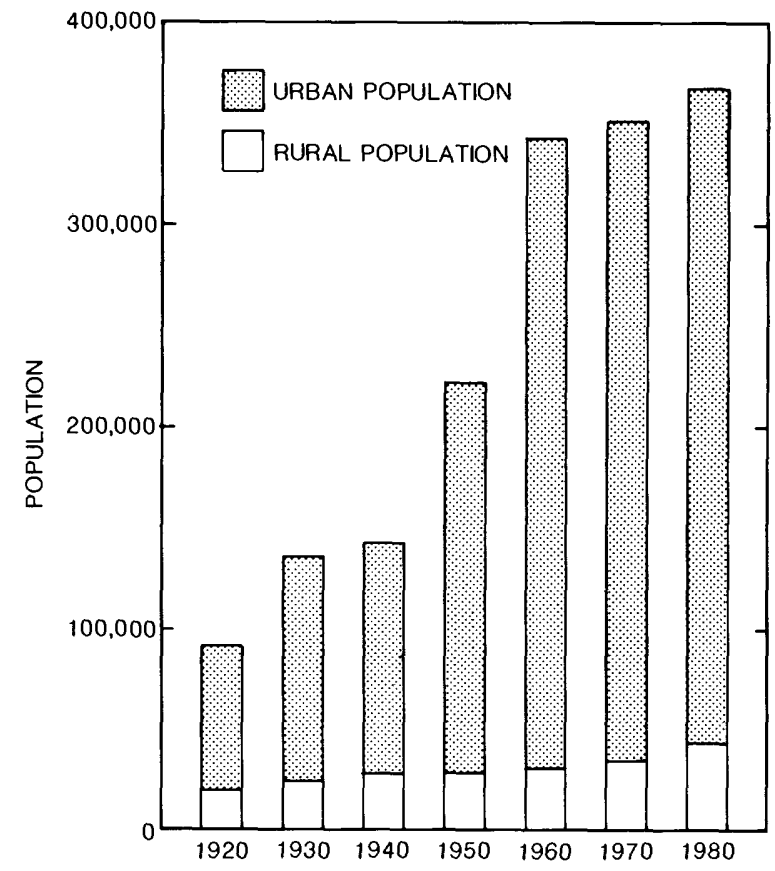

Figure 4. Population in Sedgwick County, 192080.

This would be an increase of about 16.5 percent over the 1980 population and the third largest increase in number of people experienced during any decade. On the basis of population trend for 1960 through 1980 (fig. 4), the 1990 population could actually be less than 400,000 . The Wichita-Sedgwick County Metropolitan Area Planning Department has projected the 1990 county population to be 406,000 (Lorenz and others, 1985). Accurate population projections are important because they are used to project future water use.

In 1983 , the total personal income for the county $(\$ 5,119,642,000)$ was the largest in the State (Murray, 1985). This personal income resulted from private nonfarm income $\mathbf{7 9 . 1}$ percent), government income disbursements (20.5 percent), and farm income $(0.4$ percent).
These percentages underscore the importance of private non frm economic activities.

Private nonfarm employment data for the Wichita Standard Metropolitan Statistical Area (SMSA), which includes Sedgwick and Butler Counties, can be used to illustrate the relative importance of economic activities that are included in this category. The total private nonfarm-employed labor force for the Wichita SMSA during 1983 was 165,800 . Manufacturing activities employed 30 percent of the total; trade, 27 percent; service industries, 24 percent; financial activities, 6 percent; transportation, 6 percent; construction, 5 percent; and mining (sand, gravel, oil, gas, salt), 2 percent. The aircraft industry, which employed 17 percent of the total private nonfarm labor force, was the largest employer in the manufacturing sector, which includes durable goods (fabricated metal, machinery, and transportation equipment) and nondurable goods (food products, printing and publishing, chemicals, and petroleum refining). The dominance of manufacturing in the private nonfarm employment sector is significant because manufacturing processes typically require large quantities of water.

Farm income in Sedgwick County during 1983 was $\$ 22,637,000$, or only about 0.4 percent of the total personal income. However, the county is a major agricultural region, as evidenced by its 1984 ranking in the State for the number of farms (first), acres harvested (third), crop value (tenth), and livestock and poultry value (twentieth). Although agriculture is not economically as important as manufacturing, it often requires substantial quantities of water for irrigation purposes. During 1985, 45,000 acres of land in the county were irrigated for growing sorghum, corn, wheat, and soybeans (Kansas State Board of Agriculture, 1986).

Land use in the county is primarily for agriculture. In 1984, about 83 percent of the county was included in farms (Murray, 1985). Land use on farms was approximately 84-percent cropland, 15-percent pastureland, and 1-percent woodland. About 16 percent of the county is urban land (residential, commercial, and industrial), which is a very large percentage in this part of the United States. Activities associated with land-use categories often affect water resources. 


\section{WATER-SUPPLY REQUIREMENTS}

\section{Water Use}

Water resources in the area are used as sources of public, irrigation, self-supplied industrial, and self-supplied domestic water supplies. Estimated water use in Sedgwick County during 1985 (Joan Kenny, U.S. Geological Survey, oral commun., 1986) and 1984 appropriated water rights (data from Kansas State Board of Agriculture, Division of Water Resources, Topeka) are presented in table 1. Appropriated water rights totaled 244,300 acre-feet in 1984, of which nearly 77 percent were ground-water rights. An estimated 134,200 acre-feet of water were used during 1985 . The estimated use includes self-supplied domestic use, which does not require a water right. For those categories that require a water right (public supplies, irrigation, and self-supplied industrial use), only about 53 percent of the water rights were actually used.
Since 1960, appropriated ground-water rights have increased slightly from 185,300 acrefeet (Lane and Miller, 1965a) to 187,800 acre-feet in 1984. However, the apportionment of these rights has changed as public-supply rights have decreased by 33 percent, irrigation rights have increased by 118 percent, and self-supplied industrial rights have increased by 7 percent. An estimated 107,900 acre-feet of ground water were used during 1985 (excluding self-supplied domestic use) or about 57 percent of the groundwater rights. The principal use of ground water was for irrigation, about 45 percent of the total ground water used. The areal distribution of ground-water rights is shown in figure 5.

Surface-water rights have increased greatly from 817 acre-feet in 1960 (Petri and others, 1964), all of which was for irrigation, to 56,500 acre-feet in 1984 , of which 93 percent was for public-water supplies. Of the 56,500 acre-feet of appropriated surface-water rights, only 21,500 acre-feet were used during 1985 or about 38

Table 1. Estimated water use in Sedgwick County during 1985 and 1984 appropriated water rights, in acre-feet

[Numbers rounded to nearest 100 acre-feet]

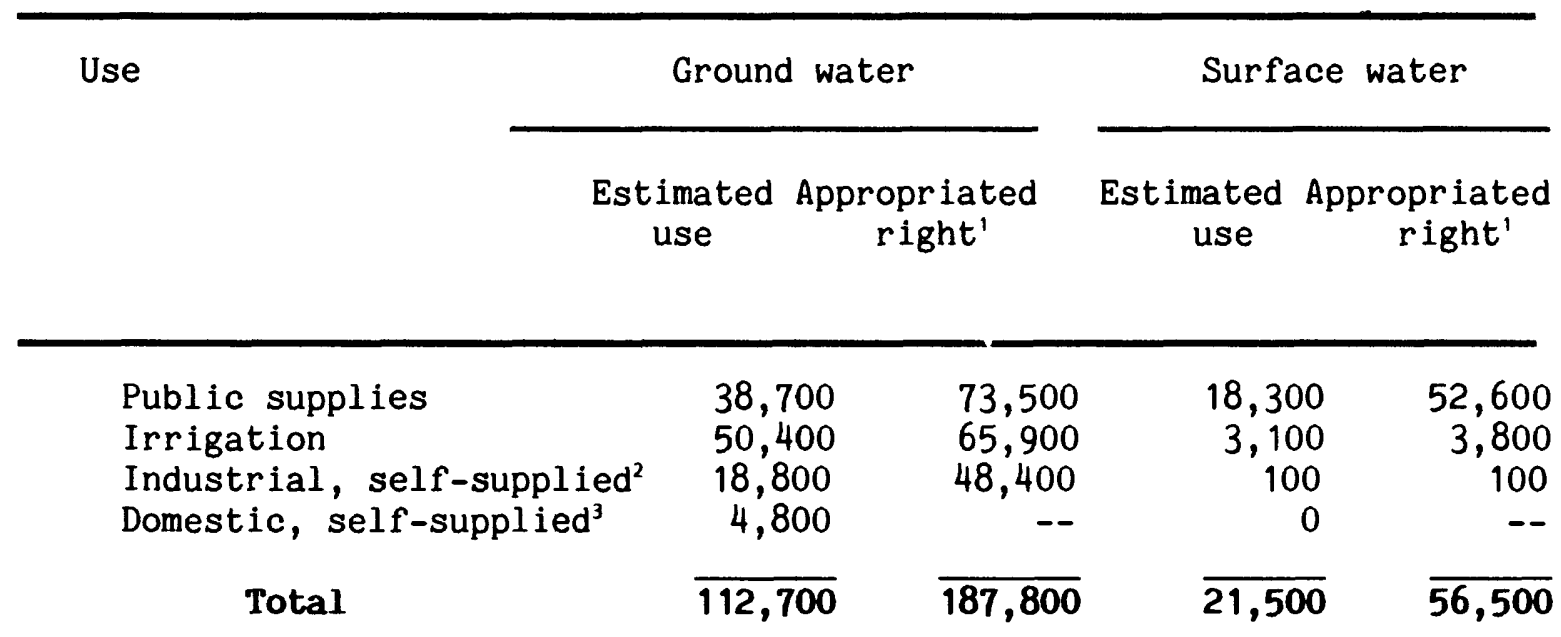

\footnotetext{
' Water-right appropriations in 1984, pending and approved; data from Kansas State Board of Agriculture, Division of Water Resources, Topeka.

${ }^{2}$ Includes: (1) manufacturing processes, (2) fossil-fuel power generation, (3) mining, and (4) nonirrigation agricultural activities (feedlots, dairy operations, fish farms).

${ }^{3}$ Water right not required.
} 


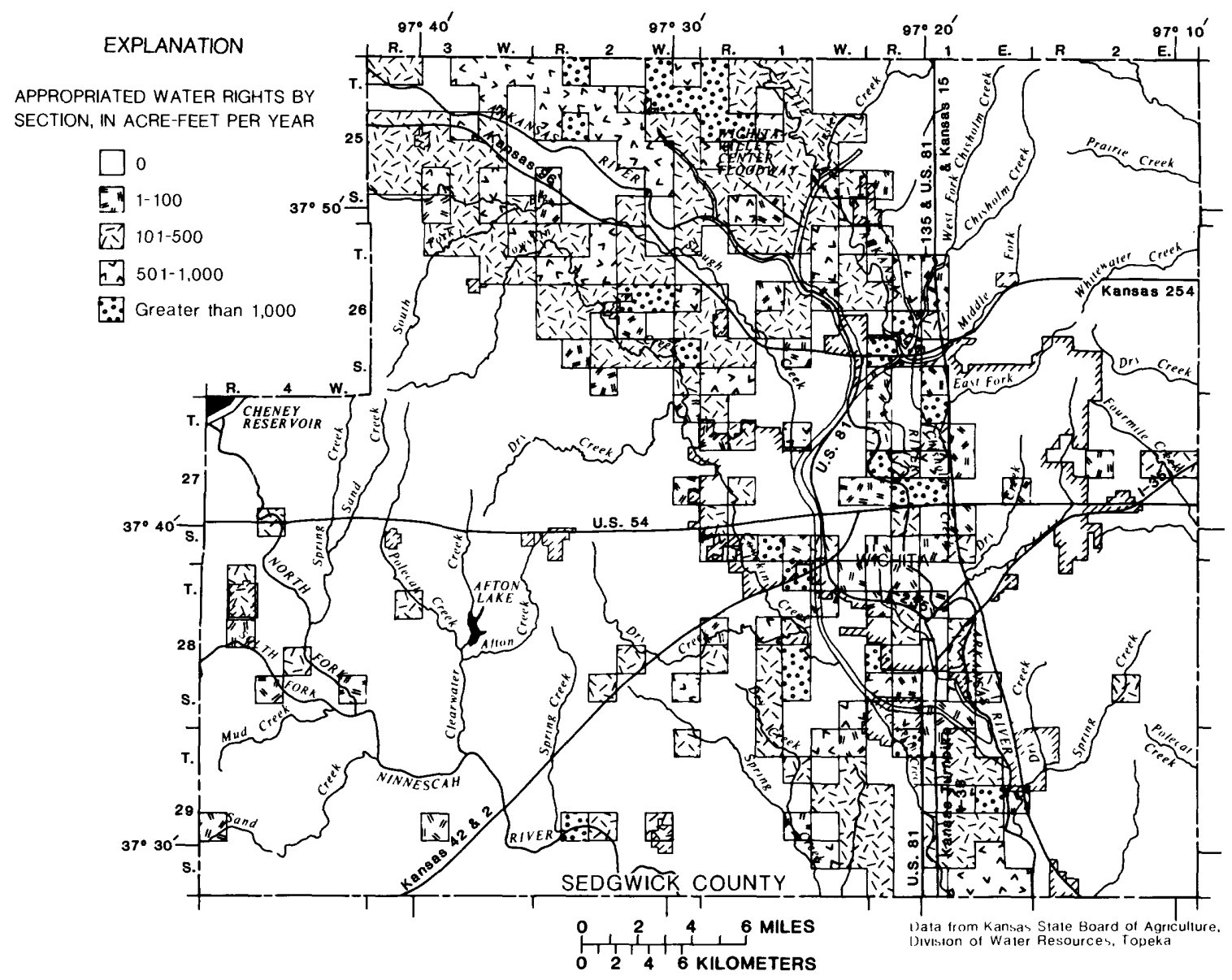

Figure 5. Distribution of 1984 appropriated water rights in Sedgwick County.

percent of the rights.

The largest category of water use in Sedgwick County during 1985 was public supply (42 percent). The 57,000 acre-feet used amounted to about 45 percent of the water rights appropriated for public supplies. The Wichita Water Utility used 53,500 acre-feet of water during 1985, or about 94 percent of the water used for public supplies. The Wichita Water Utility provides water service to Wichita, suburban areas east of Wichita, improvement areas in or adjacent to Wichita (Eastborough, Oaklawn, and Sunview), and provides wholesale water service to Park City, Kechi, Rural Water Districts 1 and 2, and small towns in western Butler County (Andover, Benton, and Rose Hill) (Lorenz and others, 1985). Public-water supplies provided by the Wichita Water Utility were used for residential (45 percent), commercial (30 percent), industrial (15 percent), and municipal and other uses (10 percent) (Lorenz and others, 1985).
All of the surface-water rights for public supplies $(52,600$ acre-feet per year from Cheney Reservoir) and 79 percent of the ground-water rights for public supplies $(40,000$ acre-feet per year from the Equus beds in southwest Harvey and northwest Sedgwick Counties, and 17,900 acre-feet per year from a local well field just upstream of the confluence of the Arkansas and Little Arkansas Rivers) belong to the city of Wichita. If the Wichita water-treatment plant could fully utilize this 110,500 acre-feet of water, the Wichita Water Utility should have adequate supplies through 2015 , based on an extrapolation of the historic urban-population growth rate of 2.8 percent per year from 1920 through 1980 and an average urban water-use rate of 0.16 acre-foot per person per year from 1960 through 1980 . From 1960 through 1980, the urban-population growth rate has been only 0.18 percent per year, which would allow water supplies to meet demand for a much longer time. Other cities or improvement districts with ground-water public- 
supply rights include Mount Hope, Valley Center, Kechi, Park City, Colwich, Maize, Cheney, Goddard, Clearwater, Haysville, and Derby (fig. 1). Nearly 90 percent of the population of Sedgwick County is served by water from public supplies.

The appropriation of water rights for irrigation has increased greatly during the past 25 years, from about 31,000 acre-feet in 1960 to 69,700 acre-feet in 1984. Irrigation accounted for the greatest use of ground water in the county during 1985. The estimated 50,400 acre-feet of ground water used for irrigation in 1985 accounted for 45 percent of the total ground water used. During 1985, irrigation required a greater percentage of its combined appropriated ground- and surface-water rights (77 percent or 53,500 acre-feet to irrigate 45,000 acres) than any other water use. From 1975 through 1983, 241 irrigation wells were installed in the county (data from Kansas Department of Health and Environment, Topeka). Nearly all of these wells were located in the Arkansas River valley.

Appropriated water rights for selfsupplied industrial use in the county have increased slightly from 45,300 acre-feet in 1960 to about 48,500 acre-feet $(48,400$ acre-feet are from ground water) in 1984 . Estimated water use for self-supplied industrial purposes amounted to only 39 percent of the appropriated rights. During 1985 , about 15 percent of the water supplies provided by the Wichita Water Utility (about 8,000 acre-feet) were used for industrial purposes. Industry was the greatest user of water in 1960 , but in 1985 it ranked a distant third behind public supplies and irrigation. Most industrial wells are located in the Arkansas River valley.

Accurate estimates for the self-supplied domestic water-use category are the most difficult to develop. Water rights are not required for self-supplied domestic water use. Because 90 percent of the population in Sedgwick County is served by public-water supplies, domestic self-supplied use is relatively minor. The 1985 estimate for this use $(4,800$ acre-feet of ground water) is about 13 percent less than the 1960 estimate (Lane and Miller, 1965a). A principal component of self-supplied domestic use is lawn and garden watering. From 1975 through 1983, 2,450 domestic wells and 1,070 lawn and garden wells were completed in Sedgwick County (data from Kansas Department of Health and Environment, Topeka). Most of these wells were located in the western part of Wichita and adjacent outlying areas.

\section{Water-Quality Criteria}

Water-quality characteristics are critical factors in determining the suitability of a source for water supplies. Although water can be processed to meet most water-quality criteria, the costs involved often are prohibitive. The preferred approach is to utilize water resources that require no or minimal treatment to meet required water-quality criteria. Supplies for different water-use categories are subject to different water-quality criteria. Important uses of water in Sedgwick County include public supplies, industry, and irrigation.

Domestic-water supplies provided by public utilities are included in the water-use category of public-water supplies. Although public-water supplies are used for many purposes other than drinking water, including additional domestic uses (bathing, laundering, waste disposal, and lawn and garden watering), industrial uses (steam generation, cooling, and processing), and municipal uses (firefighting, watering parks and other public areas, and street cleaning), the water is treated to meet drinking-water standards. Selected waterquality criteria for water resources used as sources of public-water supplies and selfsupplied domestic water supplies are listed in table 2 (National Academy of Sciences and National Academy of Engineering, 1973; U.S. Environmental Protection Agency, 1986a, b, c). Most properties and constituents listed in table 2 either hamper or cannot be removed by conventional treatment processes.

Industrial uses of water in Sedgwick County include steam generation, cooling, and process water for manufacturing of food and beverages, chemicals, petroleum, and primary metals products. In general, water-quality criteria for industrial uses are not as stringent as those for public-water supplies. Food and beverage industries are an exception in that they often require processing water that meets drinking-water standards. 
The principal industrial uses of water in the county are for steam generation and cooling processes. In general, boiler-makeup water for steam generation should be of adequate quality to: (1) Form no scale or other deposits, (2) cause no corrosion of metal components of the system, (3) not foam, and (4) not contain enough silica to form turbine-blade deposits in high-pressure boilers. Cooling water should be: (1) Non scaling with reference to limited solubility compounds, such as calcium carbonate, sulfate, and phosphate, (2) nonfouling as a result of sedimentary deposits or biological growths, and (3) noncorrosive to materials in the system (National Academy of Sciences and National Academy of Engineering, 1973).

Water used in other industrial categories (chemicals, petroleum, and primary metals) can be extremely variable in the quality required. Some chemical-processing water must meet or exceed drinking-water standards. However, usually the quantity of available water is more important than the quality in these industries. Water-quality characteristics of water resources that have been used as sources of industrial water supplies are given in table 3 (National Academy of Sciences and National Academy of Engineering, 1973).

Irrigation is a principal use of water in Sedgwick County. The water-quality criteria required for irrigation depend greatly on the type of crop and soil characteristics. The salinity of the soil-water solution available to plants is probably the most important water-quality consideration, as it affects the ability of a plant to obtain water. Most crops grown in the county (wheat, corn, and sorghum) are classified as having a medium salt tolerance or they can tolerate a soil-water solution with a specificconductance range of 6,000 to $10,000 \mu \mathrm{S} / \mathrm{cm}$ (microsiemens per centimeter at $25^{\circ} \mathrm{C}$ ). Specific conductance is a measure of the ability of a substance to conduct an electrical current and can be directly related to the concentration of ions in solution. Fruit crops are much more sensitive to salinity, generally requiring that soil-water solutions have a specific conductance that is less than $4,000 \mu \mathrm{S} / \mathrm{cm}$ (National Academy of Sciences and National Academy of Engineering, 1973).

Irrigation water with less than $500 \mathrm{mg} / \mathrm{L}$ (milligrams per liter) dissolved solids usually will not have detrimental effects on crops (U.S. Environmental Protection Agency, 1986a). In relatively humid regions where irrigation is generally supplemental in nature, such as in Sedgwick County, and natural rainfall is adequate to leach salts from the soil, relatively saline water can be used. The permissible number of irrigations with saline water in humid regions that can be applied between leaching rains to crops with small (fruit crops) and medium (vegetable, field, and forage crops) salt tolerances are indicated in table 4.

The ratio of the cations sodium, calcium, and magnesium $\left(\mathrm{Na}^{+}, \mathrm{Ca}^{++}\right.$, and $\mathrm{Mg}^{++}$, respectively) in water is important in evaluating its suitability as a source of irrigation supplies. The sodium-adsorption ratio (SAR) is a measure of the adsorbable sodium in water. If too much sodium is adsorbed to clay soils, conditions result that are unfavorable for water movement and plant growth. The SAR is computed by the following formula:

$$
\mathrm{SAR}=\frac{\mathrm{Na}^{+}}{\sqrt{\frac{\mathrm{Ca}^{++}+\mathrm{Mg}^{++}}{2}}},
$$

where $\mathrm{Na}^{+}, \mathrm{Ca}^{++}$, and $\mathrm{Mg}^{++}$are expressed in milliequivalents per liter. Generally, a SAR of 4 or less is tolerable to fruit crops, and a SAR limit of 8 to 18 is tolerable to vegetable, field, and forage crops (U.S. Environmental Protection Agency, 1986a). Sandy soils are not as susceptible to sodium hazards.

Recommended maximum concentrations of other properties and constituents in irrigation water are given in table 5 (National Academy of Sciences and National Academy of Engineering, 1973). Although the amount of water used for livestock watering is relatively small, the waterquality characteristics are important (table 5). 
Table 2. Selected water-quality criteria for water used as source of public-and domestic-water supplies [mg/L, milligrams per liter; $\mu \mathrm{g} / \mathrm{L}$, micrograms per liter]

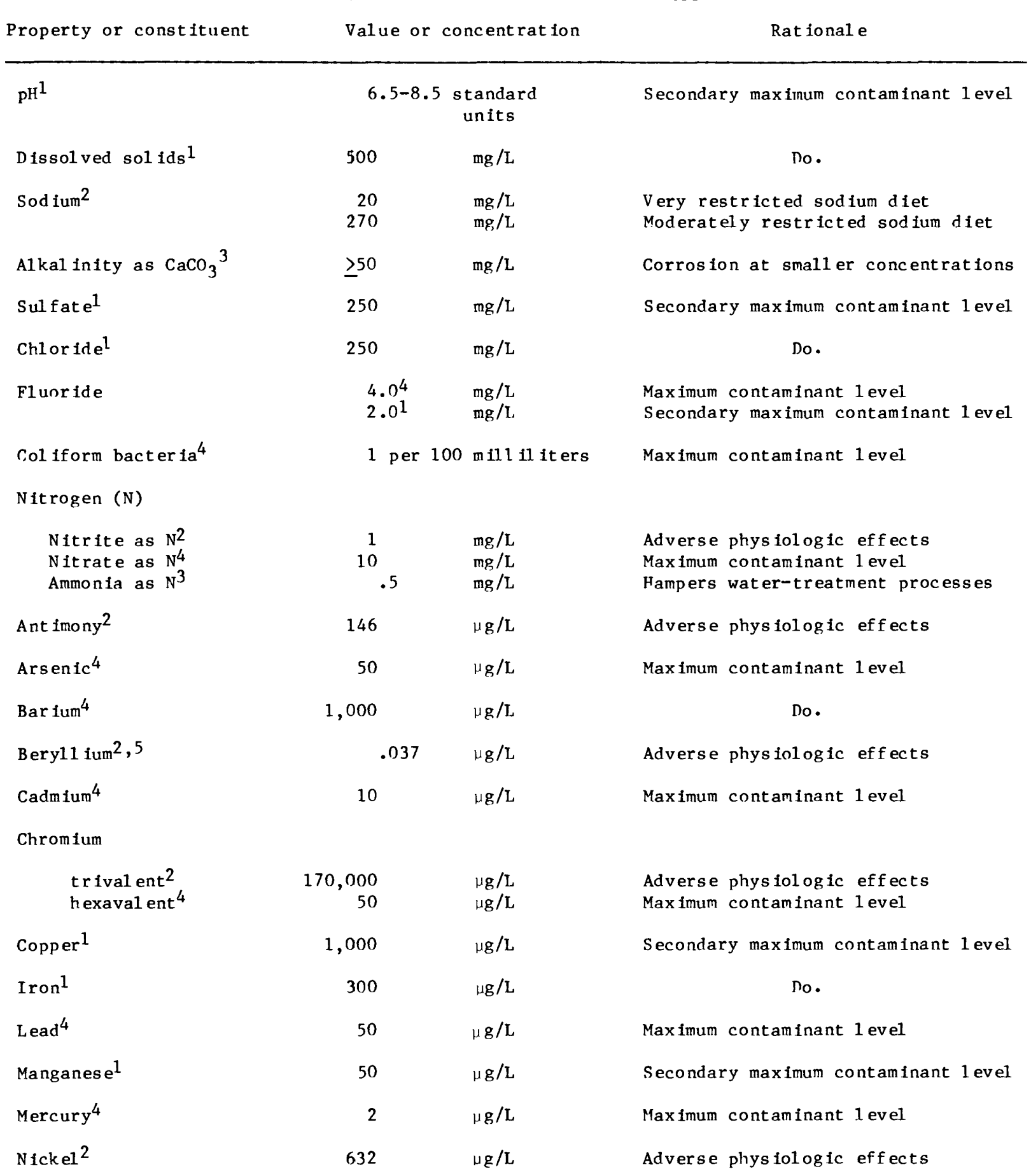


Table 2. Selected water-quality criteria for water used as source of public-and domestic-water supplies--Continued

\begin{tabular}{|c|c|c|c|}
\hline Property or constituent & \multicolumn{2}{|c|}{ Value or concentration } & Rat ional e \\
\hline Sel en ium 4 & 10 & $\mu \mathrm{g} / \mathrm{L}$ & Maximum contaminant 1 evel \\
\hline S il ver ${ }^{4}$ & 50 & $\mu \mathrm{g} / \mathrm{L}$ & Do. \\
\hline Thall Ium $^{2}$ & 13 & $\mu \mathrm{g} / \mathrm{L}$ & Adverse physiologic effects \\
\hline Zinc $^{1}$ & 5,000 & $\mu \mathrm{g} / \mathrm{L}$ & Secondary maximum contaminant level \\
\hline Cyanide $e^{2}$ & 200 & $\mu \mathrm{g} / \mathrm{L}$ & Adverse physiologic effects \\
\hline \multicolumn{4}{|l|}{ Chlorophenoxy herbicides } \\
\hline $\begin{array}{l}2,4-D^{4} \\
2,4,5 T^{3} \\
\text { S il vex }\end{array}$ & $\begin{array}{r}100 \\
2 \\
10\end{array}$ & $\begin{array}{l}\mu \mathrm{g} / \mathrm{L} \\
\mu \mathrm{g} / \mathrm{L} \\
\mu \mathrm{g} / \mathrm{L}\end{array}$ & $\begin{array}{l}\text { Maximum contaminant } 1 \text { evel } \\
\text { Adverse physiologic effects } \\
\text { Maximum contaminant level }\end{array}$ \\
\hline \multicolumn{4}{|l|}{ Organochlorine insecticides } \\
\hline $\begin{array}{l}\text { Aldrin } \text { in }^{2,5} \\
\text { Chlordane } \\
\text { DDT } 2,5 \\
\text { Dieldrin }{ }^{2}, 5 \\
\text { Endosul fan }\end{array}$ & $\begin{array}{l}.00074 \\
.0046 \\
.00024 \\
.00071\end{array}$ & $\begin{array}{l}\mu \mathrm{g} / \mathrm{L} \\
\mu \mathrm{g} / \mathrm{L} \\
\mu \mathrm{g} / \mathrm{L} \\
\mu \mathrm{g} / \mathrm{L} \\
\mu \mathrm{g} / \mathrm{L}\end{array}$ & $\begin{array}{c}\text { Adverse physiologic effects } \\
\text { Do. } \\
\text { Do. } \\
\text { Do. } \\
\text { Do. }\end{array}$ \\
\hline $\begin{array}{l}\text { Endr in } \\
\text { Heptachlor } 2,5 \\
\text { Heptachl or epoxide }{ }^{3} \\
\text { L indane } \\
\text { Methoxychlor }\end{array}$ & $4^{.0} . .02$ & $\begin{array}{l}\mu \mathrm{g} / \mathrm{L} \\
\mu \mathrm{g} / \mathrm{L} \\
\mu \mathrm{g} / \mathrm{L} \\
\mu \mathrm{g} / \mathrm{L} \\
\mu \mathrm{g} / \mathrm{L}\end{array}$ & $\begin{array}{c}\text { Maximum contaminant level } \\
\text { Adverse physiologic effects } \\
\text { Do. } \\
\text { Maximum contaminant level } \\
\text { Do. }\end{array}$ \\
\hline Toxaphene $^{4}$ & 5 & $\mu \mathrm{g} / \mathrm{L}$ & Do. \\
\hline $\begin{array}{l}\text { Organophosphorus and carbar } \\
\text { pesticides } 3 \text {, combined }\end{array}$ & 100 & $\mu \mathrm{g} / \mathrm{L}$ & Adverse physiologic effects \\
\hline $\begin{array}{l}\text { Diazanon } \\
\text { Malathion } \\
\text { Parathion } \\
\text { Trithion } \\
\text { Methomyl }\end{array}$ & $\begin{array}{l}100 \\
100 \\
100 \\
100 \\
100\end{array}$ & $\begin{array}{c}\mu \mathrm{g} / \mathrm{L} \\
\mu \mathrm{g} / \mathrm{L} \\
\mu \mathrm{g} / \mathrm{L} \\
\mu \mathrm{g} / \mathrm{L} \\
\mu \mathrm{g} / \mathrm{L}\end{array}$ & $\begin{array}{l}\text { Do. } \\
\text { Do. } \\
\text { Do. } \\
\text { Do. } \\
\text { Do. }\end{array}$ \\
\hline $\begin{array}{l}\text { Propham } \\
\text { Sevin }\end{array}$ & $\begin{array}{l}100 \\
100\end{array}$ & $\begin{array}{l}\mu g / L \\
\mu g / L\end{array}$ & $\begin{array}{l}\text { Do. } \\
\text { Do. }\end{array}$ \\
\hline \multicolumn{4}{|l|}{ Volatile organic compounds ${ }^{2}$} \\
\hline $\begin{array}{l}\text { Benzene } 5 \\
\text { Benzidine } \\
\text { Bis (Chl oromethyl) ether } 5 \\
\text { Carbon tetrachl or id } e^{5} \\
\text { Chloroform } 5\end{array}$ & $\begin{array}{l}6.6 \\
.0012 \\
.0000376 \\
4 \\
1.9\end{array}$ & $\begin{array}{l}\mu \mathrm{g} / \mathrm{L} \\
\mu \mathrm{g} / \mathrm{L} \\
\mu \mathrm{g} / \mathrm{L} \\
\mu \mathrm{g} / \mathrm{L} \\
\mu \mathrm{g} / \mathrm{L}\end{array}$ & $\begin{array}{l}\text { Do. } \\
\text { Do. } \\
\text { Do. } \\
\text { Do. } \\
\text { Do. }\end{array}$ \\
\hline
\end{tabular}


Table 2. Selected water-quality criteria for water used as source of public-and domestic-water supplies-.-Continued

$\begin{array}{lll}\text { Property or constituent } & \text { Value or concentration } & \text { Rationale }\end{array}$

Volatil e organic compounds ${ }^{2}-$

Cont inued

$1,1-D$ ichl oroethyl ene
$1,2-D$ ich1 oroethane

E thyl benzene

Halomethanes (total $)^{5}$

$1,1,2,2-$ Tet rachloroethane 5

Tet rachl oroethyl ene $e^{5}$

Toluene

$1,1,1-\operatorname{Tr}$ ichl oroethane

$1,1,2-T r i c h l o r o e t h a n e^{5}$

Trichloroethyl ene 5

Trihalomethane, total 4

vinyl chloride

$\begin{array}{cc}.33 & \mu \mathrm{g} / \mathrm{L} \\ 9.4 & \mu \mathrm{g} / \mathrm{L} \\ 1,400 & \mu \mathrm{g} / \mathrm{L} \\ 1.9 & \mu \mathrm{g} / \mathrm{L} \\ 1.7 & \mu \mathrm{g} / \mathrm{L}\end{array}$

$\mu \mathrm{g} / \mathrm{L}$

$\mu \mathrm{g} / \mathrm{L}$

$\mu \mathrm{g} / \mathrm{L}$

$\mu \mathrm{g} / \mathrm{L}$

$\mu \mathrm{g} / \mathrm{L}$

$\mu g / \mathrm{L}$

$\mu \mathrm{g} / \mathrm{L}$
Adverse physiologic effects

Do.
Do.
Do.
Do.
Do.
Do.
Do.
Do.
Do.

Maximum contaminant 1 evel

Adverse physiologic effects

Base-neutral extractable organic compounds ${ }^{2}$

\begin{tabular}{|c|c|c|c|}
\hline B is (2-chloro isopropyl) eth & eer 34.7 & $\mu \mathrm{g} / \mathrm{L}$ & Do. \\
\hline B 1s $\left(2-\right.$ chloroethyl ) ether ${ }^{5}$ & .3 & $\mu \mathrm{g} / \mathrm{L}$ & Do. \\
\hline Dichlorobenz ene & 400 & $\mu \mathrm{g} / \mathrm{L}$ & Do. \\
\hline Dichlorobenzid ine $e^{5}$ & .103 & $\mu \mathrm{g} / \mathrm{L}$ & Do. \\
\hline $2,4-d$ in it rotol uene $e^{5}$ & 1.1 & $\mu \mathrm{g} / \mathrm{L}$ & no. \\
\hline D iphenyl hydraz ine 5 & .422 & $\mu \mathrm{g} / \mathrm{L}$ & Do. \\
\hline Dimethyl phthal ate & 313,000 & $\mu \mathrm{g} / \mathrm{L}$ & Do. \\
\hline Diethyl phthal ate & 350,000 & $\mu \mathrm{g} / \mathrm{L}$ & Do. \\
\hline Dibutyl phthalate & 34,000 & $\mu g / L$ & Do. \\
\hline $\begin{array}{l}\text { Di-2-ethylhexyl } \\
\text { phthal ate }\end{array}$ & 15,000 & $\mu g / L$ & Do. \\
\hline F1uoranthene & 42 & $\mu \mathrm{g} / \mathrm{L}$ & Do. \\
\hline Hexachl oroethan $e^{5}$ & 19 & $\mu \mathrm{g} / \mathrm{L}$ & no. \\
\hline Hexachl orobutad iene $e^{5}$ & 4.47 & $\mathrm{~g} / \mathrm{L}$ & Do. \\
\hline Hexachl orocycl oh exane 5 & .022 & $\mu \mathrm{g} / \mathrm{L}$ & Do. \\
\hline Hexachl orocycl opentad iene & 206 & ; $\mathrm{g} / \mathrm{L}$ & Do. \\
\hline $\begin{array}{l}\text { r-Hexachl orocl oh exane } \\
\text { Technical -h exachl orocycl o- }\end{array}$ & .186 & $\mu g / L$ & Do. \\
\hline hexane & 0.052 & $\mu g / L$ & Do. \\
\hline Isophorone & 5,200 & $\mu \mathrm{g} / \mathrm{L}$ & Do. \\
\hline Nitrobenzene & 19,800 & $\mu \mathrm{g} / \mathrm{L}$ & Do. \\
\hline N-nitrosod iethyl amine ${ }^{5}$ & .008 & $\mu \mathrm{g} / \mathrm{L}$ & Do. \\
\hline If-n it rosod imethyl am ine $e^{5}$ & .014 & $\mu \mathrm{g} / \mathrm{L}$ & Do. \\
\hline $\mathrm{N}-\mathrm{nitrosod}$ ibutyl am in $\mathrm{e}^{5}$ & .064 & $\mu \mathrm{g} / \mathrm{L}$ & Do. \\
\hline$N-n$ it rosopyrol id ine ${ }^{5}$ & .160 & $\mu \mathrm{g} / \mathrm{l}$ & Do. \\
\hline $\mathrm{N}$-n itrosod iphy enyl am ine $\mathrm{e}^{5}$ & 49 & $\mu \mathrm{g} / \mathrm{L}$ & Do. \\
\hline Polychlorinated biphenyls & .00079 & $\sim \mathrm{g} / \mathrm{L}$ & Do. \\
\hline
\end{tabular}


Table 2. Selected water-quality criteria for water used as source of public-and domestic-water supplies--Continued

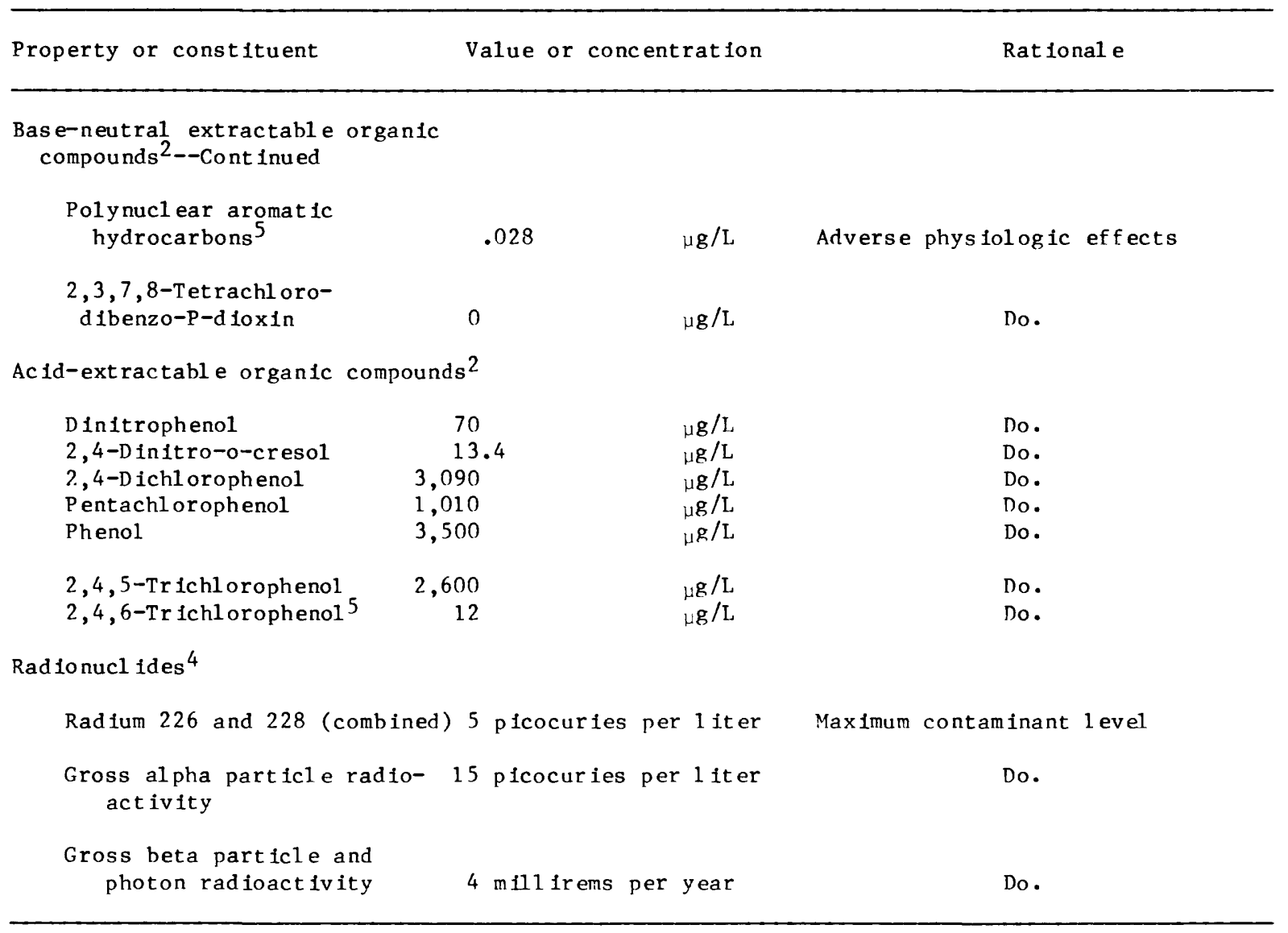

1 Data from U.S. Environmental Protection Agency, 1986b. These 1 evels are recommended standards.

2 Data from U.S. Environinental Protection Agency, 1986a.

3 Data from National Academy of Sciences and National Academy of Engineering, 1973.

4 Data from U.S. Environmental Protection Agency, 1986c. These 1 evels are enforceable standards.

5 This concentration might result in a 0.00001 increase of cancer $r$ isk over a 1 if et ime. 
Table 3. Water-quality characteristics of water resources that have been used as sources for selected industrial supplies

[Values shown in milligrams per liter $(\mathrm{mg} / \mathrm{L})$ or micrograms per liter $(\mu \mathrm{g} / / \mathrm{L})$, unless otherwise indicated. Values represent maximum concentrations or acceptable range. Data from National Academy of Science and National Academy of Engineering (1973)]

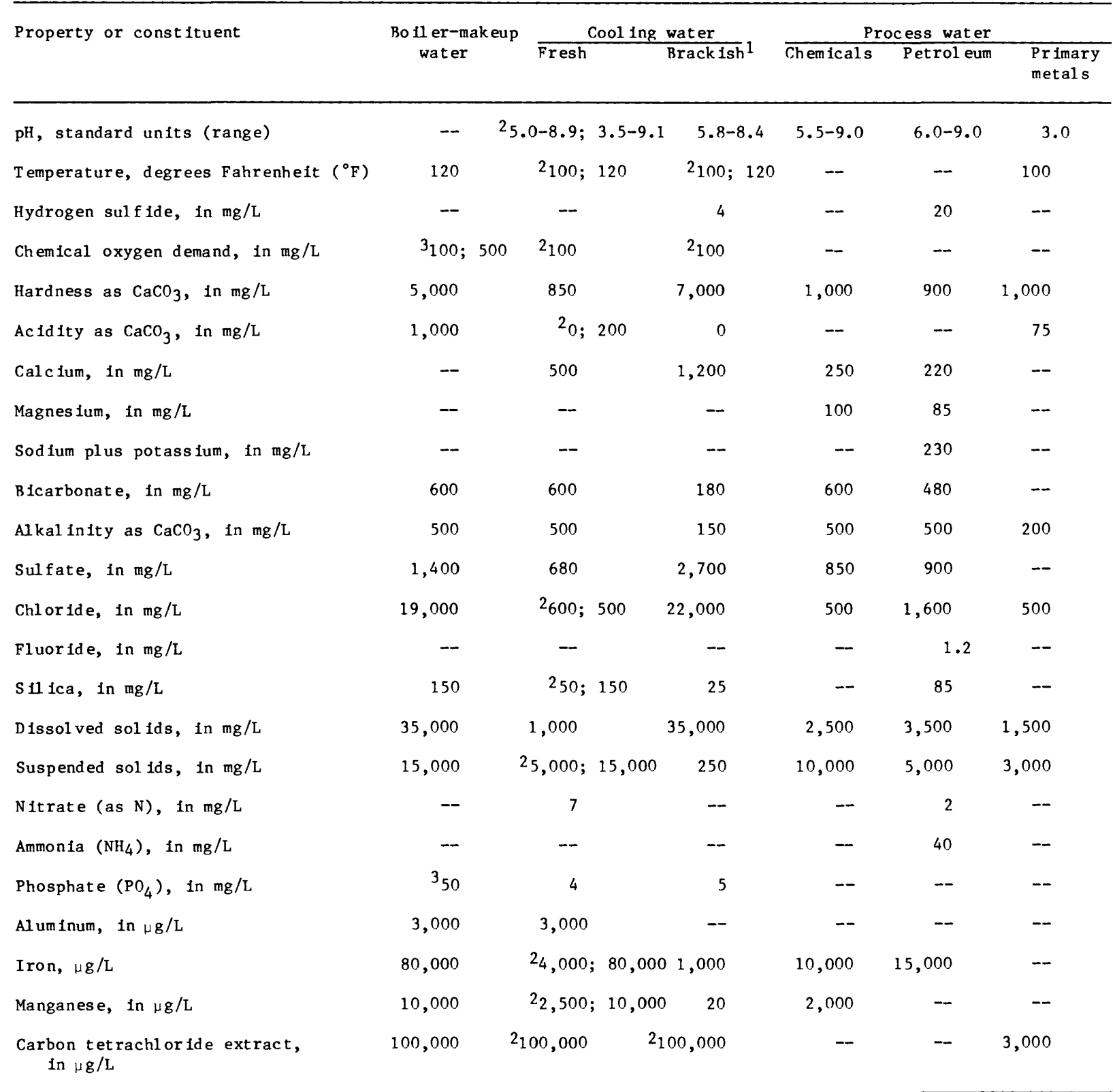

1 Defined in this report as water with more than 1,000 mill igrams per 1 it er dissolved solids.

2 For makeup recycle water.

3 For ut il ities. 
Table 4. Permissible number of irrigations with saline water in humid regions between leaching rains for indicated crops

[Data from National Academy of Sciences and National Academy of Engineering (1973)]

Irrigation water

Number of irrigations for general crop type

Dissolved solids, Specific conductance, in milligrams per in microsiemens per liter

centimeter at 25

Fruit and forage crops

Vegetables, field crops, degrees Celsius

\begin{tabular}{rrrr}
\hline 640 & 1,000 & 7 & 15 \\
1,280 & 2,000 & 4 & 7 \\
1,920 & 3,000 & 2 & $4-5$ \\
2,560 & 4,000 & 2 & 3 \\
3,200 & 5,000 & 1 & $2-3$ \\
3,840 & 6,000 & 1 & 2 \\
4,480 & 7,000 & -- & $1-2$ \\
5,120 & 8,000 & -- & 1 \\
\hline
\end{tabular}

Instream use of water for recreation and aquatic life are nonconsumptive. However, water-quality characteristics are important for maintaining aquatic habitats. Specific criteria for aquatic life are available (U.S. Environmental Protection Agency, 1986a) but are not included in this report.

\section{GEOLOGIC SETTING}

Rocks that occur at the surface in Sedgwick County are classified as sedimentary. The surface geology of Sedgwick County and selected geologic cross sections are shown in figure 6 (Lane and Miller, 1965a). Consolidated rocks generally do not occur at the surface in the county because most of the bedrock is Permian shale, which is easily eroded, and unconsolidated colluvial, fluvial, and eolian deposits occur over bedrock in most of the area. The reader is referred to Lane and Miller (1965a) for a detailed description of geology from which the following discussion is summarized.

The oldest rocks that crop out in the county belong to the Wellington Formation of the
Permian System. These rocks occur at or near the surface east of the Arkansas River valley and are the bedrock surface for the eastern two-thirds of the county. Rocks of the Wellington Formation are primarily gray and blue shale, with small, thin beds of maroon shale, impure limestone, gypsum, and anhydrite. A thick salt bed (Hutchinson Salt Member of the Wellington Formation) is present in the subsurface. The Hutchinson Salt Member occurs near the surface in the area of the Arkansas River valley, and its easily erodible nature was the major factor affecting the location of the river. The Wellington Formation ranges in thickness from a minimum of about 80 feet in some areas along the eastern edge of the county to a maximum of about 550 feet along the western edge. The Wellington Formation dips gently towards the west at about 10 feet per mile from its outcrop areas and occurs at a depth of about 180 feet along the western edge of the county.

The Ninnescah Shale of the Permian System occurs at or near the surface in the western one-third of the county and is the bedrock surface in that area. Rocks of the 


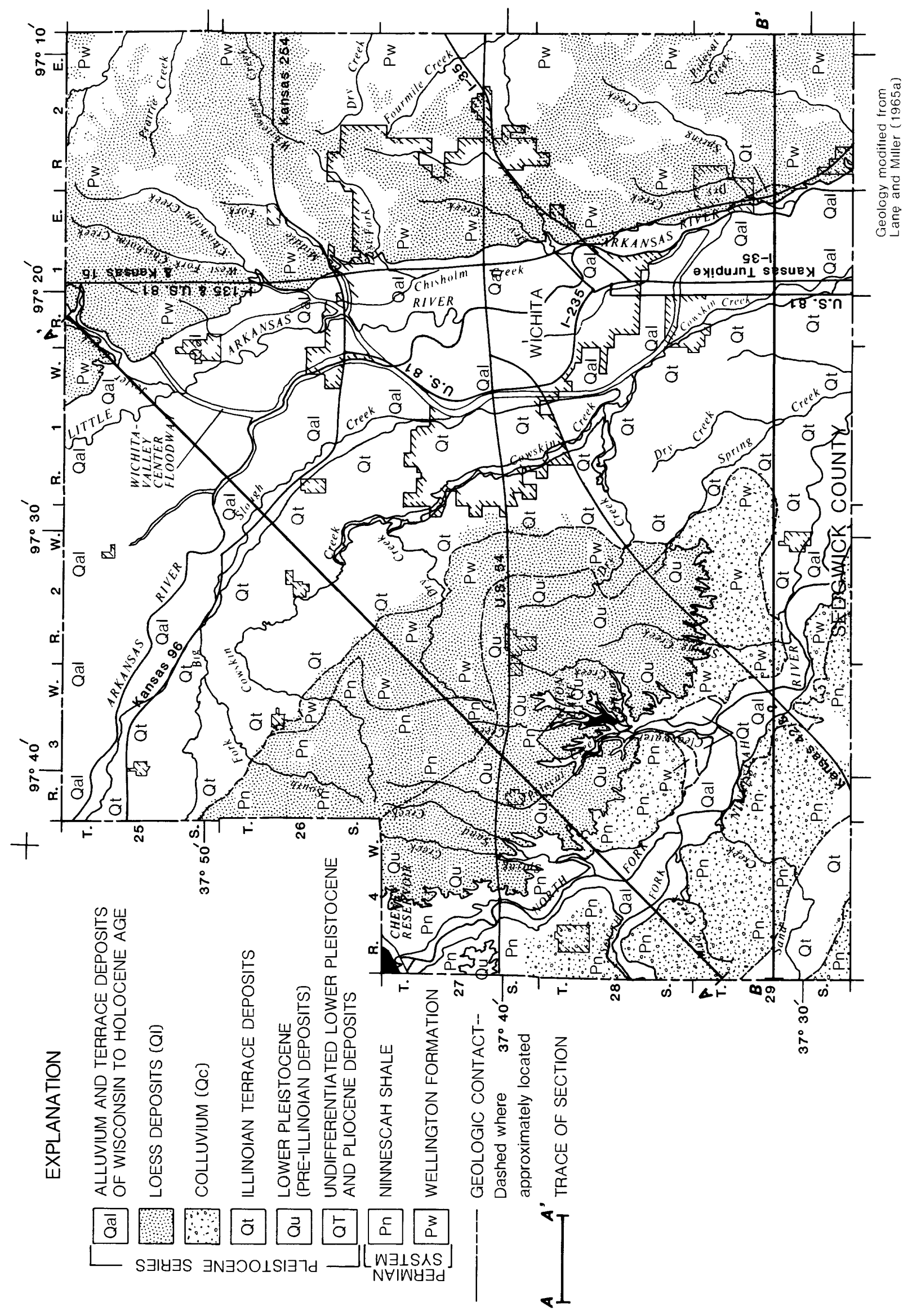



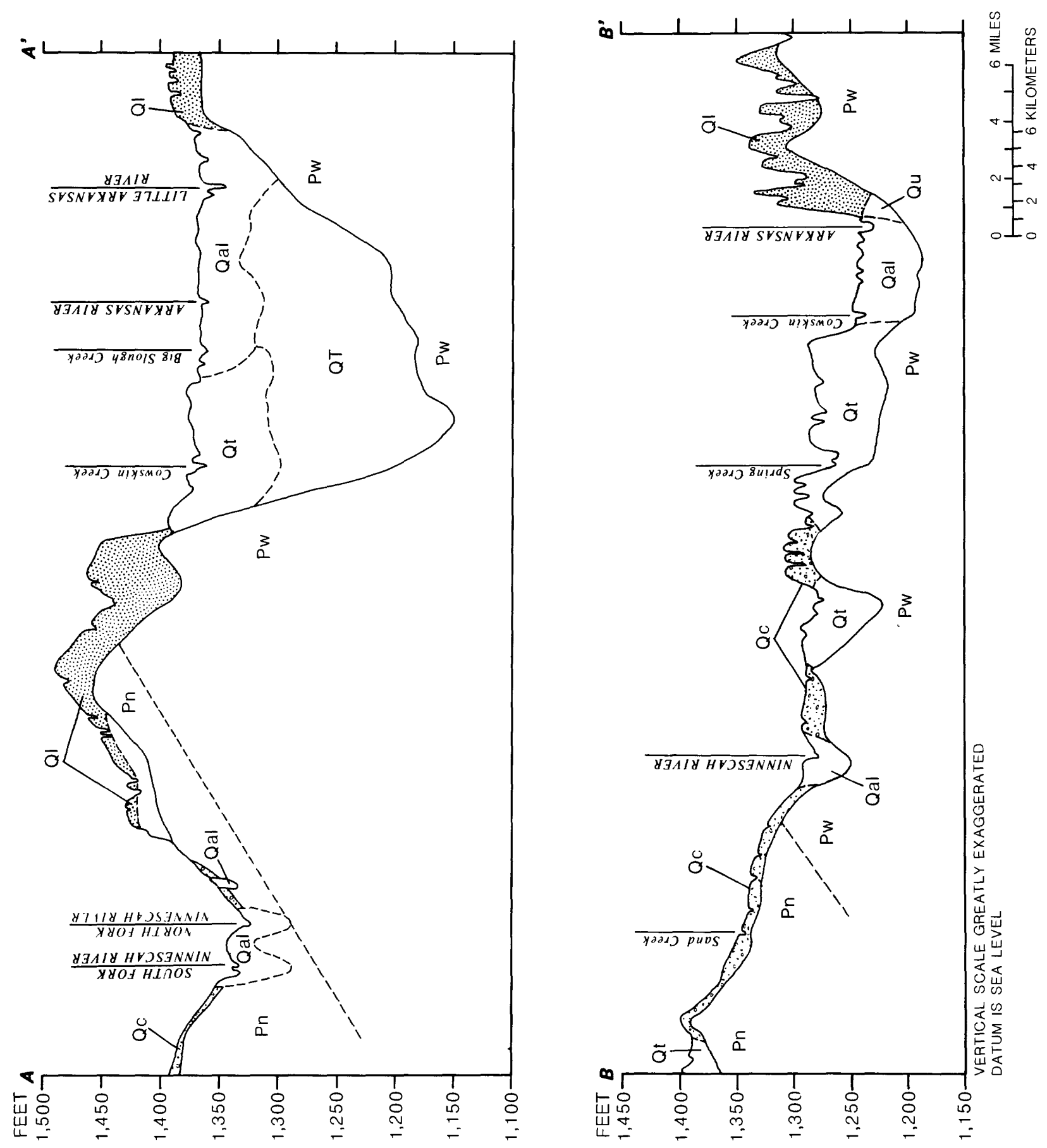

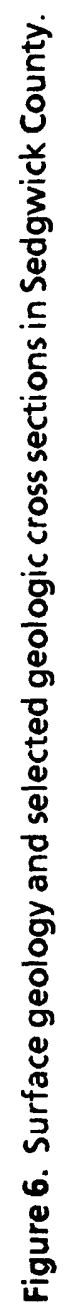


Table 5. Criteria for maximum values of selected water-quality properties and constituents in agricultural water

[From National Academy of Sciences and National Academy of Engineering (1973). Values in milligrams per liter $(\mathrm{mg} / \mathrm{L})$ or micrograms per liter $(\mu \mathrm{g} / \mathrm{L})$, unless otherwise noted]

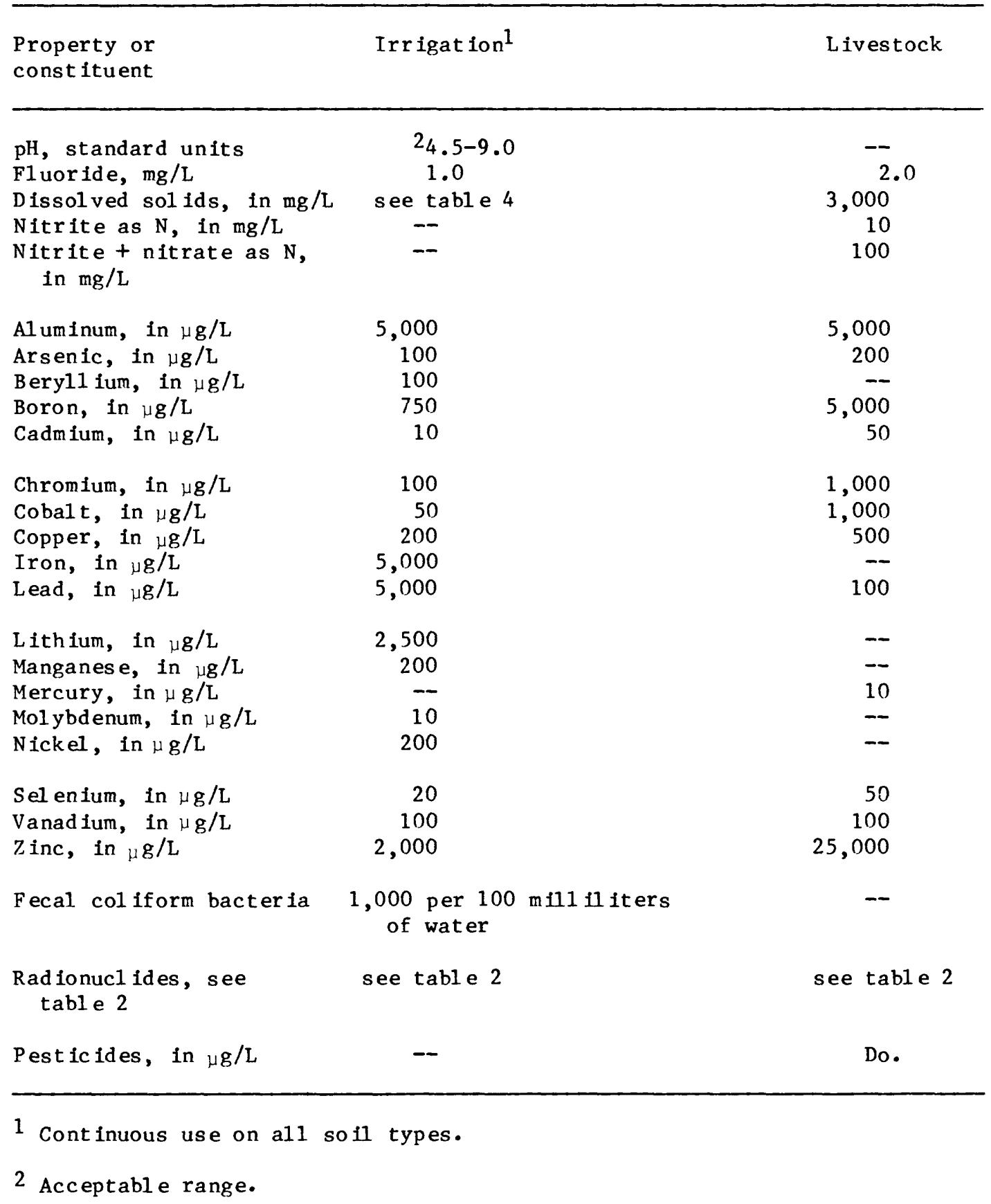


Ninnescah Shale are primarily brownish-red silty shale and siltstone, with some thin beds of grayish-green shale, dolomite, and fine-grained sandstone. The Ninnescah Shale ranges in thickness from near zero at the outcrop of its geologic contact with the Wellington Formation to about 180 feet along the western edge of the county.

Unconsolidated deposits occur over bedrock in most of the county. Undifferentiated Pliocene deposits (calcareous, gray-to-pinkish tan silt and clay, fine-to-coarse sand, and fine-tocoarse gravel; believed to be erosional remnants of the Miocene Ogallala Formation) and lower Pleistocene deposits (pre-Illinoian time) as much as 160 feet thick occur in the basal part of the Arkansas River valley fill north of Wichita. Lower Pleistocene deposits occur in the basal part of the Arkansas River valley south of Wichita at thicknesses of as much as 70 feet and on the southward-sloping uplands north of the Ninnescah River at thicknesses of as much as 20 feet. Illinoian terrace deposits (primarily fine-tocoarse sand and fine-to-coarse gravel with silty sand in the upper part and local clay and silt lenses) occur over Permian bedrock and (or) undifferentiated Pliocene and lower Pleistocene deposits along the western side of the Arkansas River valley at thicknesses of as much as 75 feet. Colluvium (heterogeneous mixture of silt, clay, sand, gravel, and bedrock fragments deposited by local slope erosional processes) of Illinoian to Holocene age occurs over Permian bedrock on both sides of the Ninnescah River valley at thicknesses of as much as 30 feet. Loess deposits (tan to pinkish-tan calcareous silt with zones of caliche nodules and sand) of Illinoian to Holocene age occur over bedrock and lower Pleistocene deposits in most upland areas at thicknesses of as much as 75 feet. Alluvium and terrace deposits (primarily fine-to-coarse sand and fine-to-coarse gravel with clayey silt in the upper part) of Wisconsin to Holocene age occur over Permian bedrock, undifferentiated Pliocene and lower Pleistocene deposits, and (or) lower Pleistocene deposits in the Arkansas River valley (as much as 60 feet thick) and in the Ninnescah River valley (as much as 50 feet thick). The total thicknesses of unconsolidated deposits range from near zero to about 80 feet in the upland areas, to as much as 50 feet in the Ninnescah River valley, and to as much as 250 feet in the Arkansas River valley.
Unconsolidated deposits of clay, silt, sand, and gravel, ranging in age from Pliocene to Pleistocene, occur in the study area over a large triangular-shaped area delineated approximately by imaginary lines connecting the cities of Hutchinson, Newton, and Wichita. These deposits form part of what is referred to as the Equus beds aquifer.

\section{SURFACE-WATER RESOURCES}

\section{Rivers and Streams}

The Arkansas River and its tributary streams, including the Little Arkansas and Ninnescah Rivers, constitute the principal surface-drainage system in the study area. The eastern edge of the area is drained by eastflowing tributaries to the Walnut River (fig. 1).

\section{Streamflow Characteristics}

The determination of streamflow characteristics requires relatively long-term streamflow records. Streamflow data collected at U.S. Geological Survey streamflow-gaging stations in the study area (fig. 1) are available for the Arkansas, Little Arkansas, North Fork Ninnescah, South Fork Ninnescah, and Ninnescah Rivers. Data from these stations were analyzed to determine historic streamflow trends, flow duration, and low- and high-flow characteristics.

\section{$\underline{\text { Historic streamflow }}$}

Examination of historic or long-term streamflow records is useful in providing a perspective of streamflow during any selected period and for detecting trends in streamflow. Very long-term streamflow records are available for the three principal streams in the study area. Mean daily streamflow data have been collected by the U.S. Geological Survey for the Arkansas River at Wichita since 1934 , for the Little Arkansas River at Valley Center since 1922, and for the Ninnescah River near Peck since 1938. Average seasonal streamflow, computed from mean daily streamflow data, for these three rivers from 1938 through 1985 is shown in figure 7. Also shown in figure 7 are cumulative departures from average streamflow (for station periods of record)., seasonal precipitation at Wichita, and cumulative departure from average precipitation (1888-1985). Precipitation at 
ONOJ $\exists S$ y

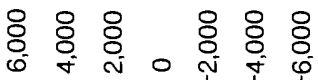

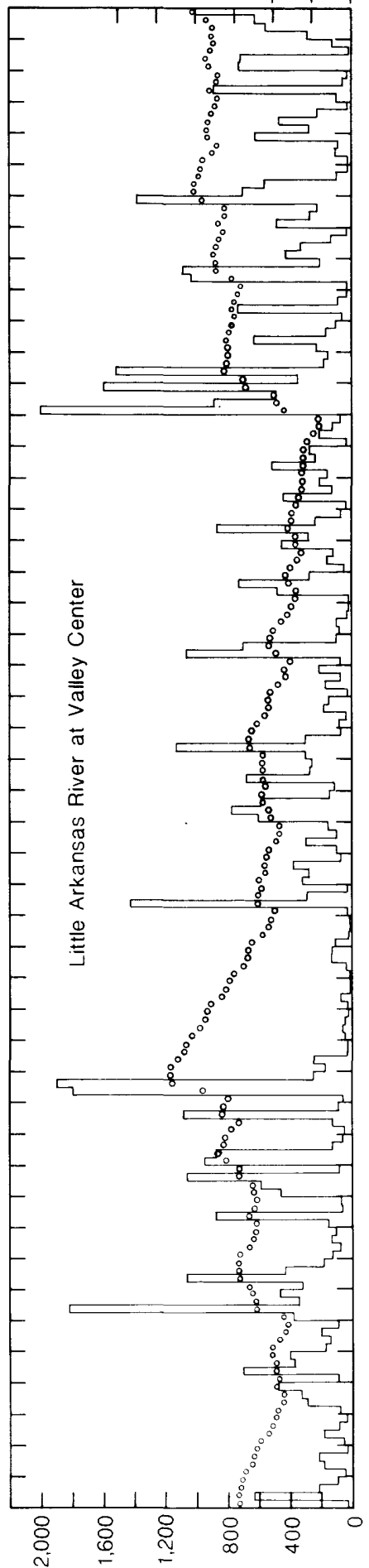

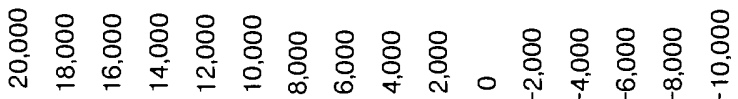

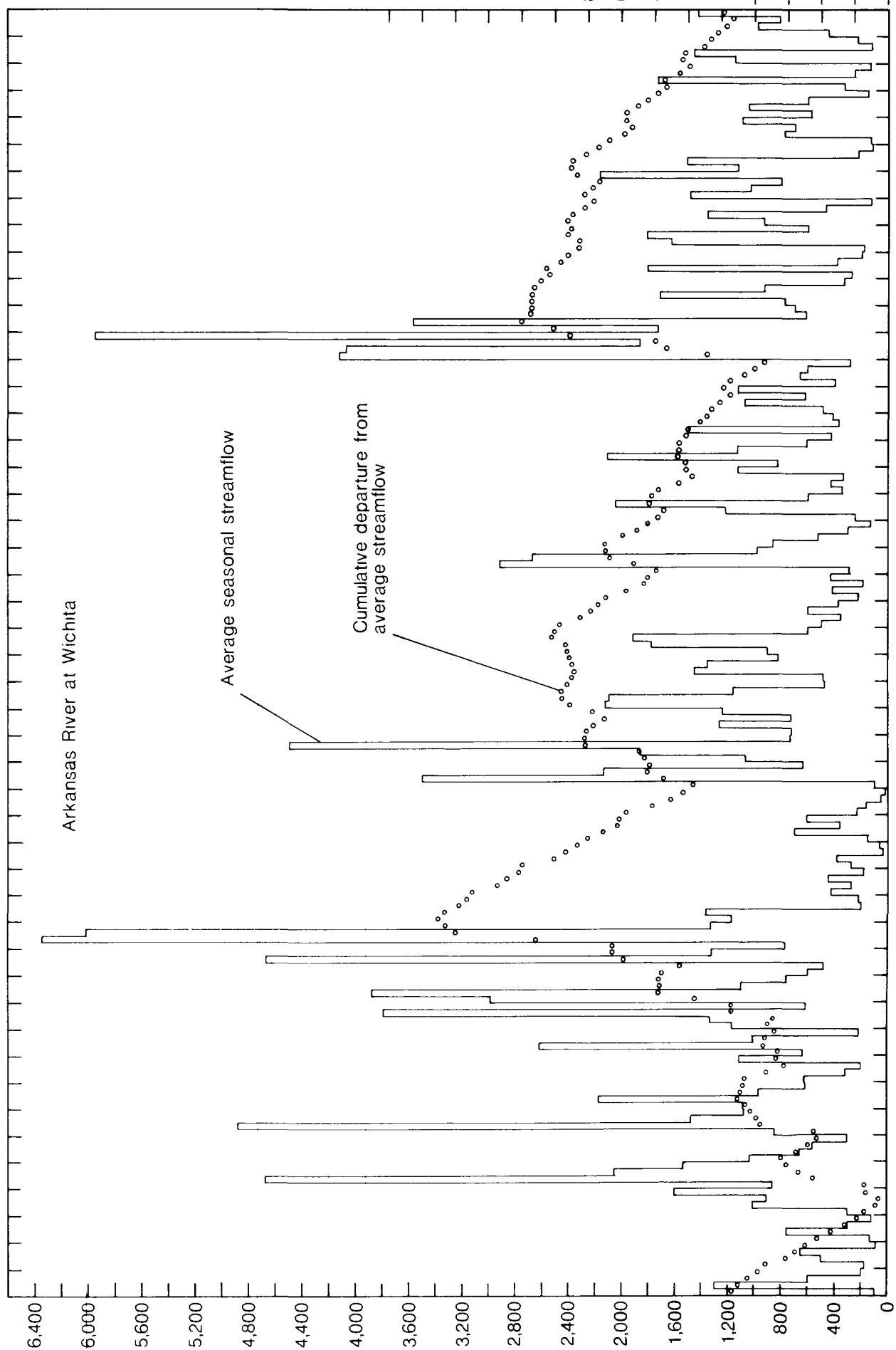

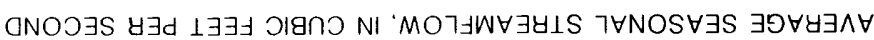




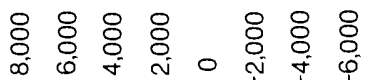
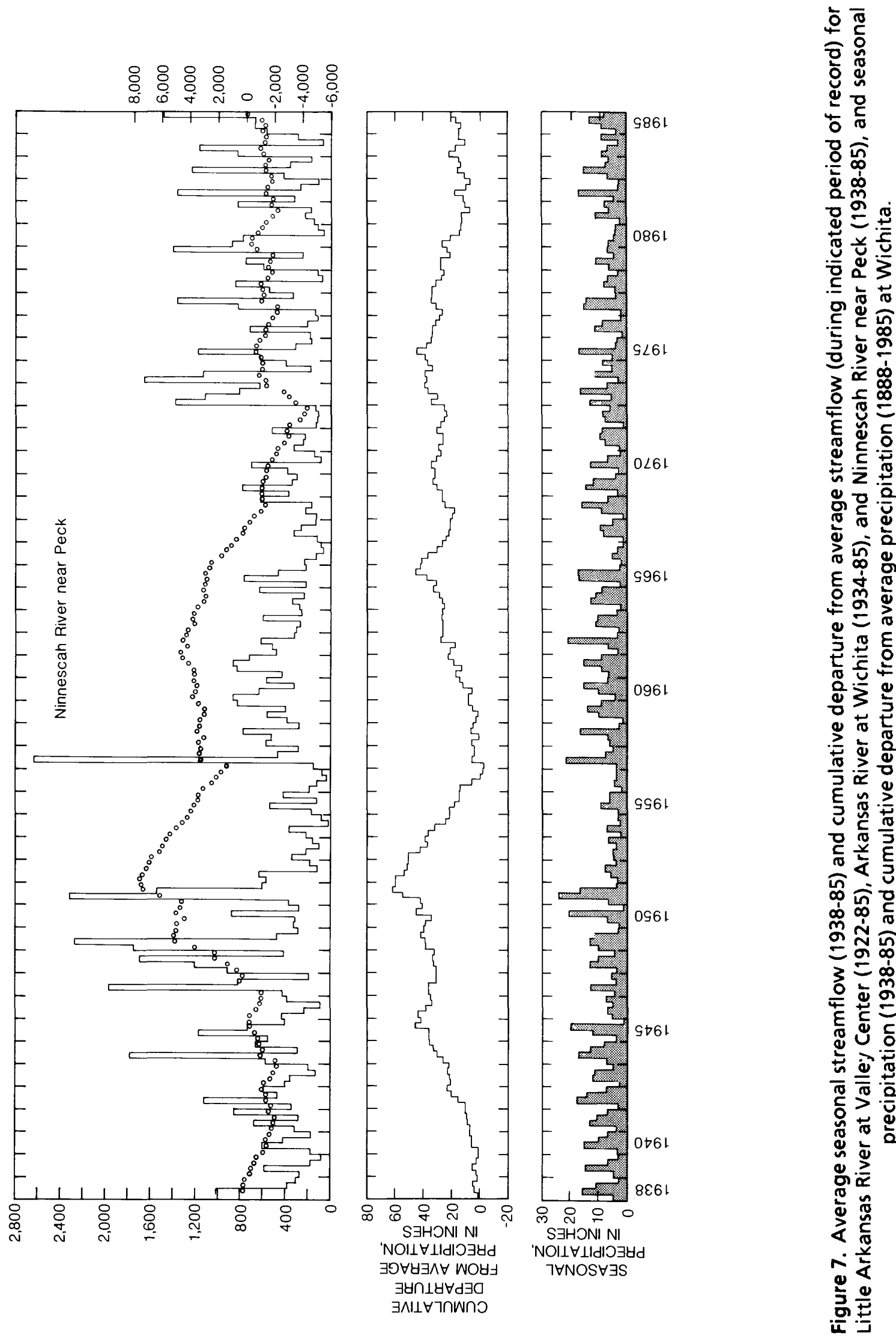
Wichita probably is not equal to that which occurs in the drainage basins of these rivers, but the trends probably are representative.

Streamflow in the study area occurs primarily in response to precipitation. Although large quantities of rainfall and corresponding large rates of streamflow can occur at any time during the year, they generally occur during the spring, as indicated by histograms of seasonal precipitation and average seasonal streamflow shown in figure 7. The smallest quantities of precipitation and rates of streamflow typically occur during the winter.

The plots of cumulative departure from average precipitation and streamflow (fig. 7) are similar, indicating the direct relationship between precipitation and streamflow. When the slopes of the cumulative departure curves are flat, the values represented are average; when the slopes are positive, the values represented are greater than average; and, when the slopes are negative, the values represented are less than average.

Prior to 1938, drought conditions had existed in the study area for several years, and, although precipitation was about average from 1938 through 1941 , streamflow was less than average. Precipitation and streamflow generally were greater than average from 1942 through 1951, except during 1943, 1946, and 1950. The wettest year on record in the area was 1951, when more than 50 inches of precipitation fell at Wichita and the highest average streamflows on record for the Arkansas River at Wichita occurred during the spring and summer. From 1952 through 1956, a severe drought occurred in the area, and precipitation and streamflow were much less than average. In 1956, the lowest average seasonal streamflow on record for the Arkansas River at Wichita occurred during the fall. The drought ended in 1957, and the highest average seasonal streamflow on record for the Ninnescah River near Peck occurred during the spring. From 1958 through 1962, precipitation and streamflow generally were average or greater than average, except during 1959. From 1963 through 1972, precipitation and streamflow generally were less than average, except during 1965 and 1969. As a result of the construction of Cheney Reservoir in 1965, cumulative departure from average seasonal streamflow for the
Ninnescah River near Peck experienced a much larger proportional decline than streamflow for the Arkansas River at Wichita and the Little Arkansas River at Valley Center during this period. In 1973 and 1974, precipitation and streamflow were greater than average as the Little Arkansas River had the highest average seasonal streamflow on record during the winter of 1973, and the Arkansas River had the thirdhighest average seasonal streamflow on record during the fall of 1973. From 1975 through 1985, precipitation and streamflow generally have been average or less than average, except during 1977 and 1979. The decline in streamflow for the Arkansas River since 1980 may be caused by less precipitation in western parts of its basin, effects of John Martin Reservoir in Colorado, increased ground-water withdrawals for irrigation, or agricultural practices, such as terracing, that decrease runoff.

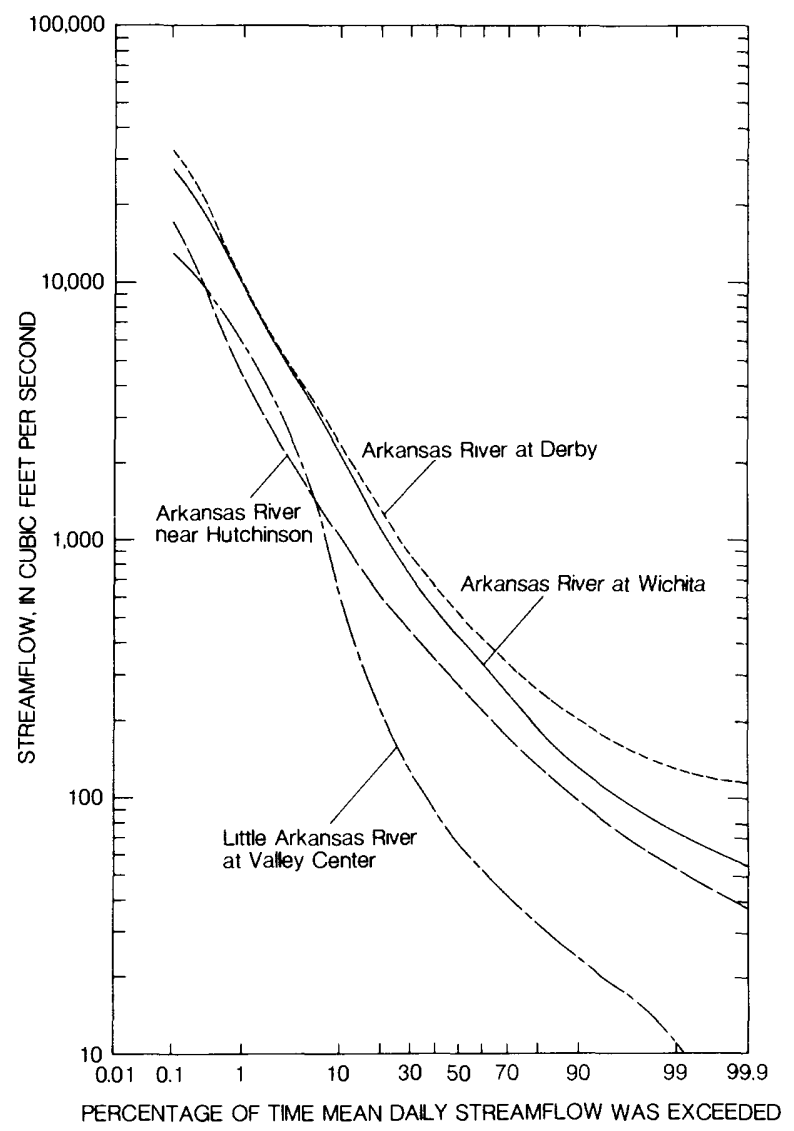

Figure 8. Flow-duration curves for Arkansas River near Hutchinson, at Wichita, and at Derby; and for Little Arkansas River at Valley Center, October 1965-September 1985. 


\section{Flow duration}

Flow-duration curves graphically display the distribution of streamflow rates through time by showing the percentage of time that a given streamflow rate is equaled or exceeded. Flow-duration curves for streamflow-gaging stations in the study area were computed from mean daily streamflow data collected during October 1965 through September 1985. This period of record was selected because: (1) Data are available for all of the gaging stations (except the Arkansas River at Derby, which was established in October 1968); (2) high-, normal-, and low-flow conditions are adequately represented; and (3) the period is representative of current conditions.

Flow-duration curves for the Arkansas River at Hutchinson, Wichita, and Derby (fig. 8) are similar in shape. The relatively flat slopes of these curves for streamflow that was exceeded 50 percent or more of the time indicate that the Arkansas River is well sustained by groundwater inflow from Permian rocks northwest of Sedgwick County and from the Equus beds aquifer (Pliocene and Pleistocene deposits of clay, silt, sand, and gravel that occur in a triangular shaped area approximately delineated by imaginary lines connecting the cities of Hutchinson, Newton, and Wichita) in Sedgwick, Harvey, and southern McPherson Counties during low-flow conditions. The higher flows in the Arkansas River at Wichita and Derby in relation to the Arkansas River near Hutchinson result primarily from streamflow contributed by the Little Arkansas River. The flatter slope of the curve representing the Arkansas River at Derby that occurs between about 50 and 99.9 percent of the time is due mainly to effluent from Wichita sewagetreatment plants. During 1982, effluent from Wichita sewage-treatment plants averaged about 60 cubic feet per second (data from Wichita Water Pollution Control Division), which is approximately equal to the difference in streamflow observed at the lower end of the curves for Wichita and Derby.

The flow-duration curve for the Little Arkansas River at Valley Center (fig. 8) has a steeper slope in the part that represents streamflow provided by surface runoff, generally less than 50 percent of the time. The relatively steep slope is a function of basin characteristics. The Little Arkansas River basin is smaller, has steeper land-surface slopes, and bedrock occurs at or near the surface throughout much of its drainage area. These factors result in more surface runoff, which reaches the channel in a relatively short time during rainstorms. The lower end of the curve for the Little Arkansas River is relatively flat, indicating that the river is well sustained by ground-water inflow from the Equus beds aquifer in northern Sedgwick, Harvey, and southern McPherson Counties. The steeper slope of the curve that occurs after about

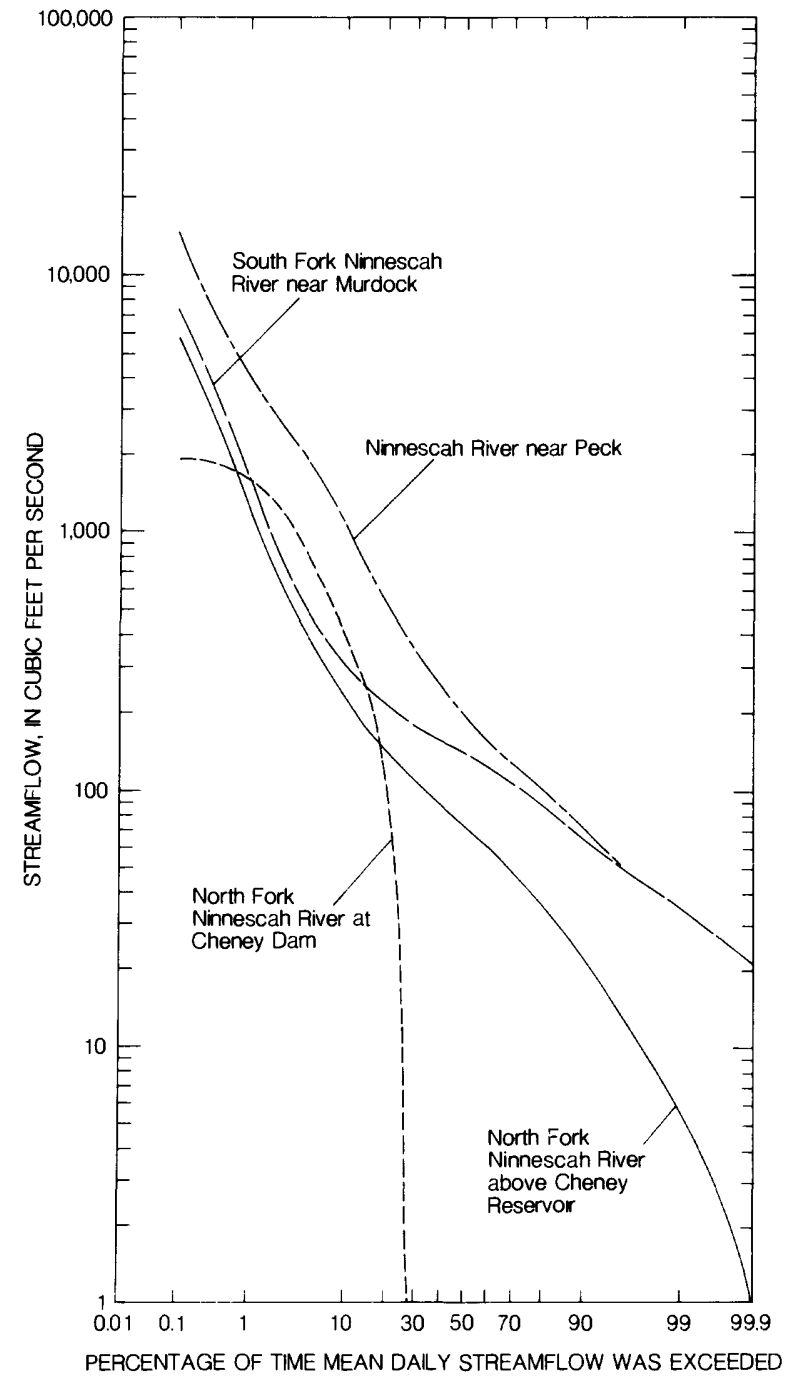

Figure 9. Flow-duration curves for North Fork Ninnescah River above Cheney Reservoir and at Cheney Dam, South Fork Ninnescah River near Murdock, and Ninnescah River near Peck, October 1965-September 1985. 
95 percent of the time might be due to groundwater withdrawals from the Wichita well field upstream from Valley Center, which result in smaller rates of ground-water inflow to the stream, or in the stream losing water.

Flow-duration curves for the North Fork Ninnescah River above Cheney Reservoir and at Cheney Dam, the South Fork Ninnescah River near Murdock, and the Ninnescah River near Peck are shown in figure 9. The curve for the North Fork Ninnescah River above Cheney Reservoir has a relatively steep slope, indicating that streamflow is provided primarily by surface runoff and that the stream is not well sustained by ground-water inflow. The curve for the North Fork Ninnescah River at Cheney Dam illustrates the regulating effect of Cheney Reservoir. The reservoir impounds the extreme high flows (those exceeded less than about 0.7 percent of the time) and releases most of the water at relatively large rates of flow between 0.7 and 20 percent of the time. After about 30 percent of the time, most of the flow is held in storage, and releases are minimal. The slope of the flow-duration curve for the South Fork Ninnescah River near Murdock is much flatter at the lower end than that of the North Fork Ninnescah River, indicating that flow is well sustained by ground-water inflow from Permian rocks west of Sedgwick County. The flowduration curve for the Ninnescah River near Peck is affected also by Cheney Reservoir. The "hump" that occurs between about 1 percent and 20 percent of the time is caused by releases from Cheney Reservoir. After about 20 percent of the time, the curve for the Ninnescah River near Peck begins to merge with that of the South Fork Ninnescah River near Murdock as less water is released from Cheney Reservoir. During smaller rates of flow, those that were equaled or exceeded more than 50 percent of the time, most of the flow in the Ninnescah River near Peck is provided by the South Fork Ninnescah River as water generally is not released from Cheney Reservoir during low-flow periods.

\section{Low-flow characteristics}

Low-flow characteristics of streams are important in evaluating their adequacy for maintaining aquatic life, providing water supplies, and abating water contamination from human activities, such as sewage disposal.
Because low flow generally is sustained by ground-water inflow, low-flow characteristics are useful also for estimating ground-water inflow.

Low-flow magnitude and frequency can be estimated from curves shown for the Arkansas River (near Hutchinson, at Wichita, and at Derby) and the Little Arkansas River at Valley Center (fig. 10) and for the North Fork Ninnescah River above Cheney Reservoir, the South Fork Ninnescah River near Murdock, and the Ninnescah River near Peck (fig. 11). The curves were manually fitted to actual data points (also shown) representing mean daily streamflow recorded from October 1965 through September 1985 and probably are representative of current (1986) conditions. Streamflow values on the curves represent the lowest mean streamflow, in cubic feet per second, that occurred during the indicated number of consecutive days $(7,30$, and 90 days) at recurrence intervals of from 1.05 to 20 years. The periods of 7,30 , and 90 consecutive days were selected because they represent weekly, monthly, and seasonal low flows.

Although the low-flow curves are presented primarily to describe low-flow magnitude and frequency during approximately the last 20 years, they can be used for prediction purposes. The error involved in using the curves for prediction purposes is estimated from visual inspection to be generally less than 25 percent. The extreme flatness at the lower ends of the low-flow curves for the Arkansas River at Derby probably is caused by effluent from Wichita sewage-treatment plants, which averaged about 60 cubic feet per second during 1982 (data from Wichita Water Pollution Control Division).

\section{High-flow characteristics}

High-flow characteristics of streams are used primarily to determine flood-control storage for reservoirs. Whereas low-flow characteristics generally describe streamflow that results from ground-water inflow, high-flow characteristics describe streamflow that results from surface runoff.

Curves showing frequency and magnitude of high flows for the Arkansas River (near 

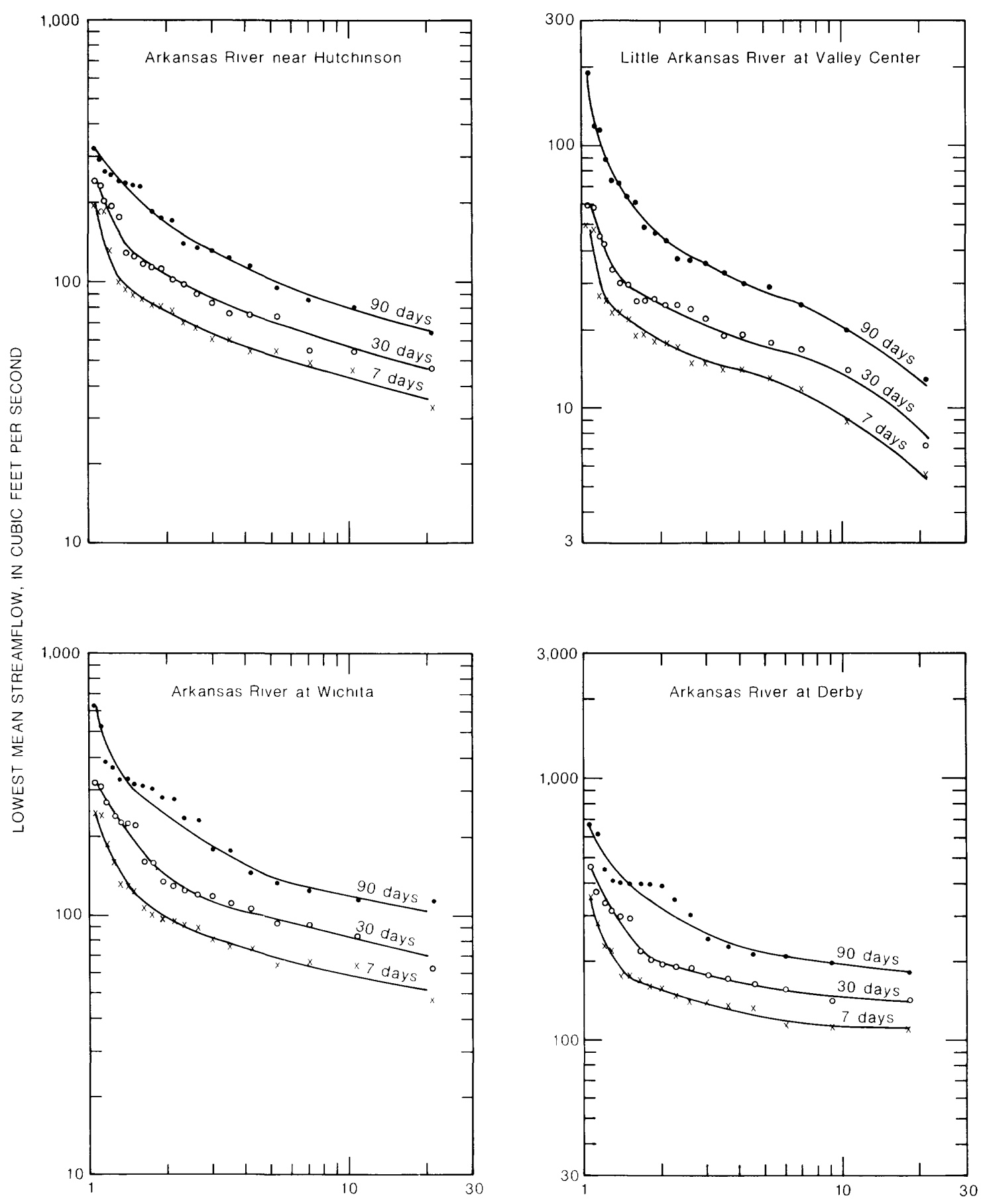

RECURRENCE INTERVAL, IN YEARS

Figure 10. Low-flow frequency curves (7, 30, and 90 consecutive days) for Arkansas River near Hutchinson, at Wichita, and at Derby; and for Little Arkansas River at Valley Center, October 1965September 1985. 


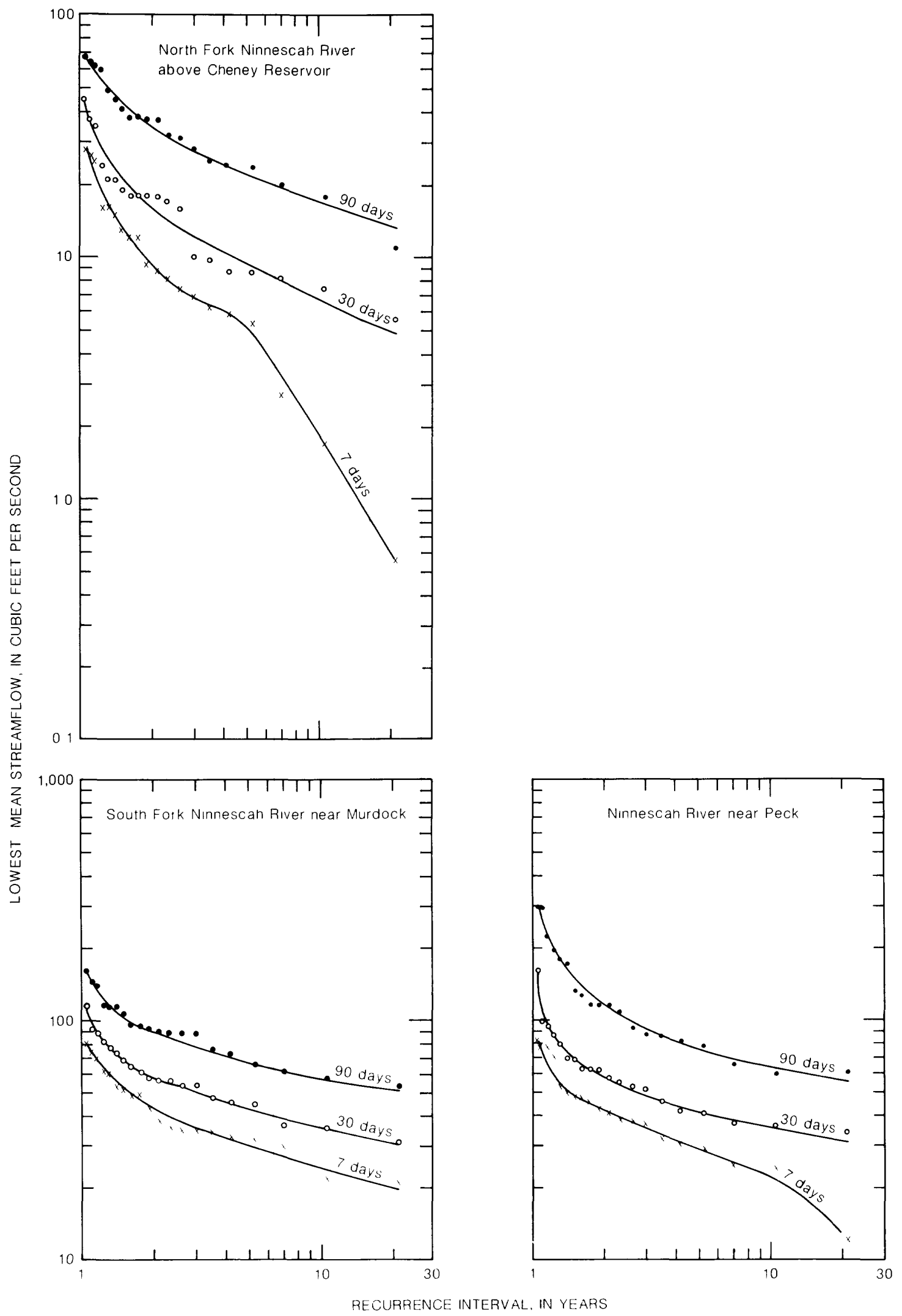

Figure 11. Low-flow frequency curves (7, 30, and 90 consecutive days) for North Fork Ninnescah River above Cheney Reservoir, South Fork Ninnescah River near Murdock, and Ninnescah River near Peck, October 1965-September 1985. 


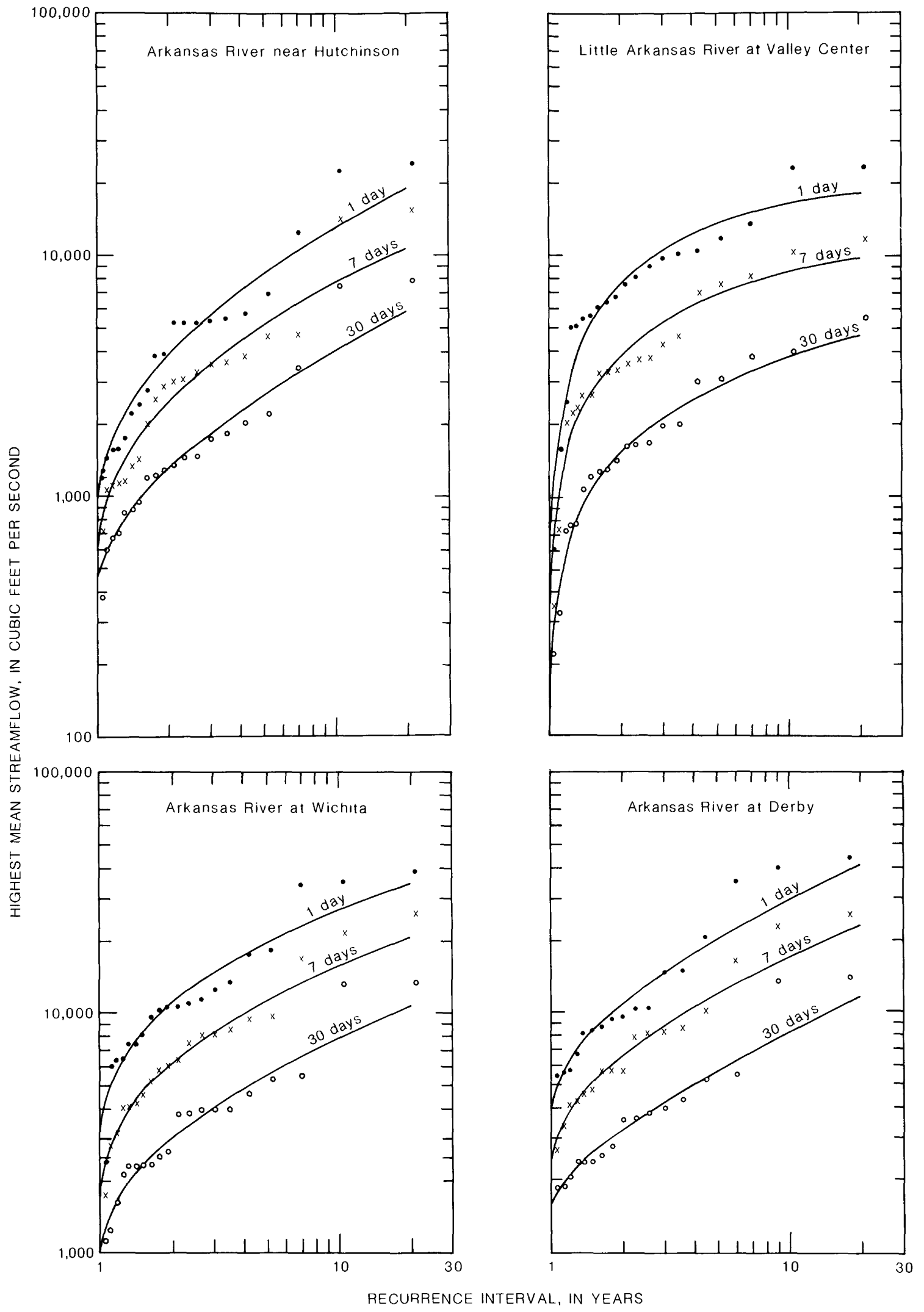

Figure 12. High-Flow frequency curves (1,7, and 30 consecutive days) for Arkansas River near Hutchinson, at Wichita, and at Derby; and for Little Arkansas River at Valley Center, October 1965September 1985. 
Hutchinson, at Wichita, and at Derby) and the Little Arkansas River at Valley Center (fig. 12) River near Murdock, and the Ninnescah River near Peck (fig. 13) were developed by fitting logPearson Type III distributions to data points (also shown) representing streamflow data collected during the same period of record used to develop the flow-duration and low-flow curves in the preceding sections. The log-Pearson Type III distribution has been approved by the U.S. Water Resources Council (1981) for frequency analysis of high flows. Streamflow values on the curves represent the highest mean streamflow, in cubic feet per second, that occurred during the indicated number of consecutive days $(1,7$, and 30 days) at recurrence intervals of from 1 to 20 years.

Although the high-flow curves were developed primarily to describe conditions that have occurred during approximately the last 20 years, they can be used also for prediction purposes. Errors that might result from using the curves for prediction, as estimated from visual inspection, are generally less than 30 percent for recurrence intervals of 5 years or less but can be greater than 50 percent for longer recurrence intervals.

\section{$\underline{\text { Streamflow gains and losses }}$}

A low-flow seepage survey of area streams was conducted during March 11-14, 1985. The purpose of this survey was to determine reaches of streams that were gaining or losing flow as a result of the interaction of ground and surface water or as a result of human activities, principally withdrawals of water for public supplies and self-supplied industrial use and subsequent return flows. The survey was conducted during winter to minimize the effects of evapotranspiration and the effects of withdrawals for irrigation. Streamflow was relatively low and steady in the major streams, and no surface runoff was occurring.

Streamflow measurements taken during the seepage survey are given with concurrently collected water-quality data (discussed later in the water-quality section) in table 11 of the "Results of Low-Flow Water-Quality Reconnaissance" section. Results of the seepage survey are summarized as follows:
The Ninnescah River is a gaining stream throughout its reach in Sedgwick County. However, in its downstream reach between the Kansas Highway 42 bridge and near Clearwater, the gain in streamflow is very small, possibly because of appropriated rights for ground-water withdrawals $(1,772$ acre-feet per year) for industrial use about 2 miles east of Clearwater.

The Little Arkansas River is a gaining stream throughout its reach in Sedgwick County. The streamflow gain between Valley Center and 37 th Street in Wichita was only about one-half of that observed between Sedgwick (near the Sedgwick-Harvey County line) and Valley Center, even though the Valley Center sewage-treatment plant was providing some of the flow south of Valley Center. Large volumes of appropriated rights for ground-water withdrawals for public supplies $(3,420$ acre-feet per year) and industrial use $(3,470$ acre-feet per year) in the reach of the Little Arkansas River from Valley Center south to 37th Street in Wichita probably is the cause of the relatively small streamflow gain. Results of an earlier hydrologic investigation in the Wichita area indicate that induced infiltration of river water from the Little Arkansas and Arkansas Rivers has occurred in northern parts of the city because groundwater levels have been lowered by withdrawals for industrial use (Petri and others, 1964).

The Arkansas River generally is a gaining stream within Sedgwick County. North of Wichita, in the reach between Mount Hope and 4 miles east of Maize, the Arkansas River gained about 20 cubic feet per second. In this reach, the river is in approximate equilibrium with the ground water and does not serve as the main drain for ground-water 


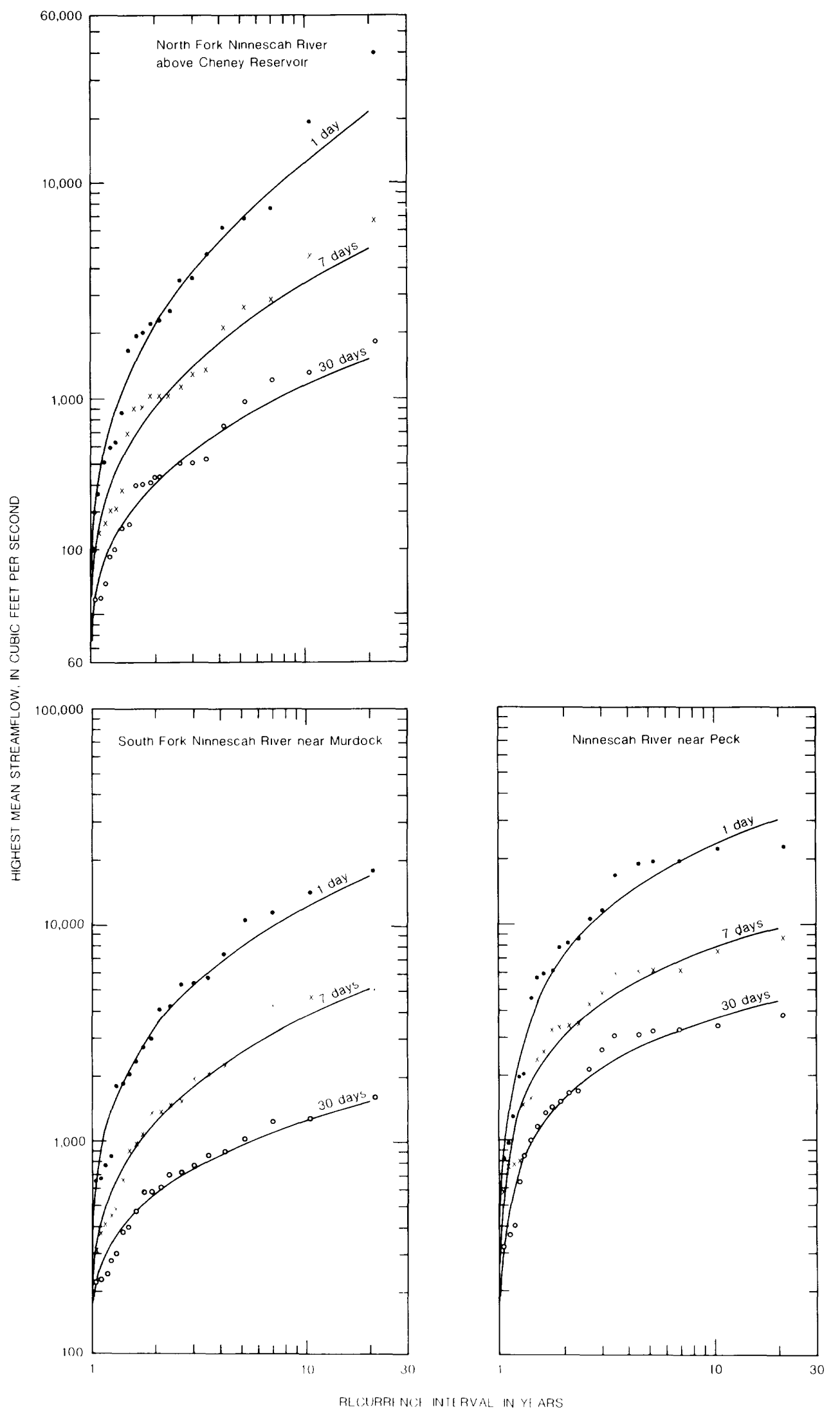

Figure 13. High-flow frequency curves (1, 7, and 30 consecutive days) for North Fork Ninnescah River above Cheney Reservoir, South Fork Ninnescah River near Murdock, and Ninnescah River near Peck, October 1965-September 1985. 
discharge; the Little Arkansas River serves as the primary drain for groundwater discharge. In north Wichita in the reach between 4 miles east of Maize and 21st Street, the Arkansas River is losing water, probably because of ground-water withdrawals for public supplies and industrial use that also affect the Little Arkansas River or because water is being lost to the Little Arkansas River, which is the primary ground-water drain. South of the confluence of the Arkansas and Little Arkansas Rivers at Pawnee Street in Wichita, flow in the Arkansas River had increased by about 70 percent from flow contributed by the Little Arkansas River and some local ground-water discharge. In the reach between Pawnee Street and Derby, flow in the Arkansas River increased by about 30 percent. About onehalf of this increase probably was due to discharge from Wichita sewage-treatment plants, which averaged about 60 feet per second during 1982 . In the reach between Derby and Mulvane, there was a slight loss of streamflow that could be caused by withdrawal of ground water for public supplies along this reach (appropriated water rights $=2,060$ acre-feet per year).

\section{Water-Quality Characteristics}

Statistical summary of water-quality properties and constituents

Water-quality data collected at U.S. Geological Survey streamflow-gaging stations on the Arkansas River (near Hutchinson, at Wichita, and at Derby), the Little Arkansas River at Valley Center, the North Fork Ninnescah River (above Cheney Reservoir and at Cheney Dam), the South Fork Ninnescah River near Murdock, and the Ninnescah River near Peck during October 1965 through September 1985 are summarized statistically in table 6 . These data represent water-quality characteristics observed in the streams during the same period of record represented in the flowduration, low-flow, and high-flow sections of this report (1965-85) and probably are representative of current (1986) conditions.

Streamflow values shown in table 6 are instantaneous measurements made during the collection of water-quality samples. Although all of the listed properties and constituents were not analyzed for each sample collected, the range of streamflows and the median streamflow for which samples were collected are reasonably representative of streamflows that occurred during 1965 through 1985 , as indicated by previously shown flow-duration curves, except for the Arkansas River at Wichita. With the exception of specific conductance and suspendedsediment data, the small amount of waterquality data available for the North Fork Ninnescah River above Cheney Reservoir may not be representative. Streamflow in the Ninnescah River at Cheney Dam is provided primarily by releases from Cheney Reservoir, and the water-quality data should represent the water-quality characteristics of Cheney Reservoir. Only a small amount of iron, manganese, and trace-element data are available for the stream stations. Suspendedsediment data generally are not available for the Arkansas River at Wichita and at Derby and for the Ninnescah River at Cheney Dam.

Water in the Arkansas River near Hutchinson has a median hardness concentration of $420 \mathrm{mg} / \mathrm{L}$ as calcium carbonate and a median dissolved-solids concentration of $1,700 \mathrm{mg} / \mathrm{L}$. The principal dissolved constituents are sodium (median concentration, $380 \mathrm{mg} / \mathrm{L}$ ) and chloride (median concentration, $540 \mathrm{mg} / \mathrm{L}$ ). Sulfate concentrations can be very large at times, as indicated by the observed maximum of $920 \mathrm{mg} / \mathrm{L}$. Most of the sodium, chloride, and sulfate result from saline ground water in Permian shale of eastern Stafford and western Reno Counties that is discharged into the Arkansas River as base flow and by Rattlesnake, Peace, and Salt Creeks (Hargadine and Luehring, 1978).

The Little Arkansas River at Valley Center contains water that has a median hardness concentration of $280 \mathrm{mg} / \mathrm{L}$ as calcium carbonate and a median dissolved-solids concentration of $480 \mathrm{mg} / \mathrm{L}$. Calcium is normally the principal cation in solution, with a median concentration of $85 \mathrm{mg} / \mathrm{L}$, and bicarbonate is the principal anion, with a median concentration of $270 \mathrm{mg} / \mathrm{L}$. However, median concentrations of sodium $(70 \mathrm{mg} / \mathrm{L})$ and chloride $(100 \mathrm{mg} / \mathrm{L})$ indicate that they are also principal dissolved constituents and sometimes might be 
Table 6. Statistical summary of selected water-quality properties and constituents for major streams, October 1965-September 1985

[mg/L, milligrams per liter; $\mu \mathrm{g} / \mathrm{L}$, micrograms per liter; $\mu \mathrm{S} / \mathrm{cm}$, microsiemens per centimeter at 25 degrees Celsius; $\mathrm{ft}^{3} / \mathrm{s}$, cubic feet per second; and <preceding a value indicates the constituent was not detected at that level]

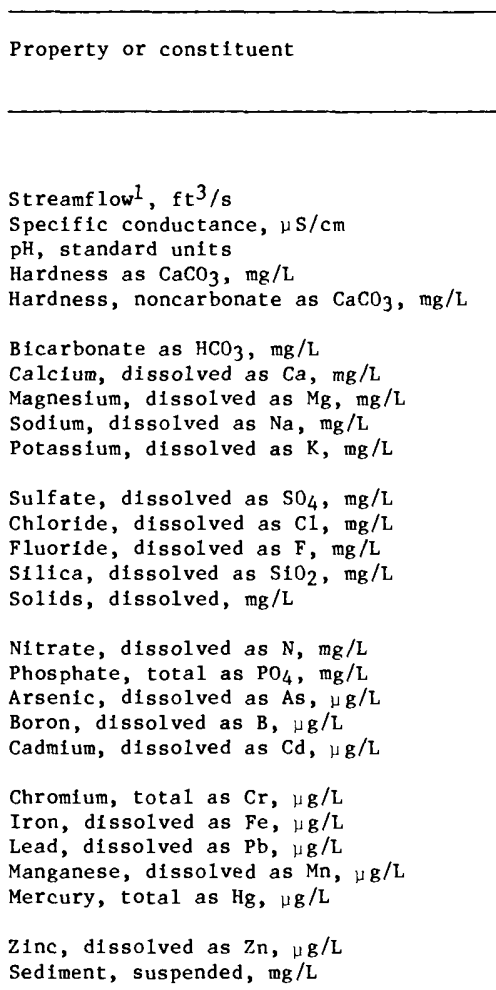

Number of Median
samples Mean Maximum Minimum $\begin{aligned} & \text { Standard } \\ & \text { deviation }\end{aligned}$

Arkansas River near Hutchinson

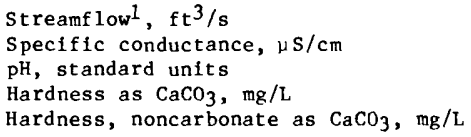

\begin{tabular}{|c|c|c|c|c|c|}
\hline 274 & 112 & 652 & 14,000 & 3.0 & 1,710 \\
\hline 220 & 832 & 842 & 1,960 & 91 & 357 \\
\hline 214 & 7.6 & 7.6 & 8.7 & 6.6 & .4 \\
\hline 130 & 280 & 260 & 470 & 1 & 100 \\
\hline 130 & 52 & 68 & 220 & 0 & 47 \\
\hline 197 & 270 & 240 & 360 & 37 & 82 \\
\hline 129 & 85 & 81 & 140 & 11 & 31 \\
\hline 129 & 15 & 15 & 32 & .6 & 6.5 \\
\hline 129 & 70 & 75 & 220 & 3.0 & 40 \\
\hline 129 & 6 & 6 & 10 & 4 & 1 \\
\hline 167 & 52 & 52 & 110 & 5.0 & 22 \\
\hline 167 & 100 & 120 & 420 & 5.0 & 76 \\
\hline 129 & .4 & .4 & .8 & .2 & .1 \\
\hline 128 & 17 & 17 & 39 & 6.2 & 5.1 \\
\hline 167 & 480 & 493 & 1,100 & 62 & 196 \\
\hline 129 & .86 & .95 & 3.6 & .04 & 5.9 \\
\hline 129 & 1.9 & 2.1 & 6.7 & .50 & .9 \\
\hline 1 & -- & -- & $<1$ & -- & -- \\
\hline 125 & 150 & 140 & 270 & 20 & 50 \\
\hline 1 & -- & - & $<1$ & -- & -- \\
\hline 1 & - & -- & $<1$ & -- & -- \\
\hline 18 & 95 & 100 & 230 & 10 & 60 \\
\hline 1 & -- & -- & 6 & -- & -- \\
\hline 16 & 10 & 70 & 280 & $<10$ & 100 \\
\hline 1 & -- & - & 3.7 & -- & -- \\
\hline 1 & -- & -- & 61 & -- & -- \\
\hline 58 & 745 & 962 & 9,990 & 50 & 1,340 \\
\hline
\end{tabular}


Table 6. Statistical summary of selected water-quality properties and constituents for major streams, October 1965-September 1985--Continued

Property or constituent $\begin{gathered}\begin{array}{c}\text { Number of } \\ \text { samples }\end{array} \\ \text { Median }\end{gathered}$ Mean Maximum Minimum $\begin{aligned} & \text { Standard } \\ & \text { deviation }\end{aligned}$

\section{Arkansas River at Wichita}

Streamf $1 \mathrm{ow}^{1}, \mathrm{ft}^{3} / \mathrm{s}$

Specific conductance, $u S / c m$

$\mathrm{pH}$, standard units

Sediment, suspended, $\mathrm{mg} / \mathrm{l}$

$\begin{array}{rccccc}24 & 409 & 1,080 & 6,340 & 1.7 & 1,540 \\ 16 & 1,780 & 1,640 & 2,240 & 775 & 489 \\ 13 & 8.0 & 7.8 & 8.9 & 6.8 & .6 \\ 2 & -- & -- & 1,230 & 459 & --\end{array}$

Arkansas River at Derby

Streamf low $1, \mathrm{ft}^{3} / \mathrm{s}$

Specific conductance, $\mu \mathrm{S} / \mathrm{cm}$ $\mathrm{pH}$, standard units

Hardness as $\mathrm{CaCO}_{3}$, $\mathrm{mg} / \mathrm{L}$

Hardness, noncarbonate as $\mathrm{CaCO}_{3}, \mathrm{mg} / \mathrm{L}$

Bicarbonate as $\mathrm{HCO}_{3}$, $\mathrm{mg} / \mathrm{L}$

Calcium, dissolved as $\mathrm{Ca}, \mathrm{mg} / \mathrm{L}$

Magnesium, dissolved as $\mathrm{Mg}$, $\mathrm{mg} / \mathrm{L}$

Sodium, dissolved as $\mathrm{Na}, \mathrm{mg} / \mathrm{L}$

Potassium, dissolved as $\mathrm{K}, \mathrm{mg} / \mathrm{l}$

Sulfate, dissolved as $\mathrm{SO}_{4}, \mathrm{mg} / \mathrm{L}$ Chloride, dissolved as $\mathrm{Cl}, \mathrm{mg} / \mathrm{L}$ Fluoride, dissolved as $\mathrm{F}, \mathrm{mg} / \mathrm{L}$

Silica, dissolved as $\mathrm{SiO}_{2}, \mathrm{mg} / \mathrm{L}$

Solids, dissolved, $\mathrm{mg} / \mathrm{l}$

Nitrate, dissolved as $\mathrm{N}, \mathrm{mg} / \mathrm{L}$ Phosphate, total as $\mathrm{PO}_{4}, \mathrm{mg} / \mathrm{l}$

Boron, dissolved as $B, \mu \mathrm{g} / \mathrm{L}$

Iron, dissolved as $\mathrm{Fe}, \mu \mathrm{g} / \mathrm{L}$

Manganese, dissolved as $\mathrm{Mn}, \mu \mathrm{g} / \mathrm{L}$

Sediment, suspended, mg/L

\begin{tabular}{|c|c|c|c|c|c|}
\hline 215 & 554 & 1,330 & 30,100 & 118 & 2,880 \\
\hline 209 & 2,050 & 1,920 & 3,560 & 290 & 680 \\
\hline 211 & 7.5 & 7.6 & 8.9 & 6.8 & .4 \\
\hline 130 & 370 & 370 & 720 & 80 & 130 \\
\hline 130 & 180 & 190 & 490 & 16 & 99 \\
\hline 197 & 230 & 220 & 340 & 66 & 54 \\
\hline 130 & 100 & 100 & 190 & 25 & 34 \\
\hline 130 & 27 & 27 & 64 & 3.4 & 12 \\
\hline 130 & 300 & 270 & 540 & 22 & 110 \\
\hline 130 & 11 & 10 & 15 & 4 & 2 \\
\hline 168 & 180 & 220 & 740 & 20 & 150 \\
\hline 169 & 380 & 370 & 760 & 33 & 150 \\
\hline 130 & .6 & .6 & 1.0 & .3 & .1 \\
\hline 130 & 13 & 12 & 25 & 1.0 & 3.9 \\
\hline 168 & 1,200 & 1,130 & 2,100 & 180 & 420 \\
\hline 129 & 1.6 & 2.0 & 13 & .32 & 1.4 \\
\hline 126 & 2.4 & 3.5 & 55 & .40 & 5.2 \\
\hline 123 & 230 & 220 & 380 & 30 & 80 \\
\hline 17 & 110 & 100 & 270 & 20 & 60 \\
\hline 14 & 10 & 14 & 130 & $<10$ & 34 \\
\hline 2 & -- & -- & 1,560 & 1,340 & -- \\
\hline
\end{tabular}

North Fork Ninnescah River above Cheney Reservoir ${ }^{2}$

Streamflow $1, \mathrm{ft}^{3 / \mathrm{s}}$

Specific conductance, $\mu \mathrm{S} / \mathrm{cm}$

$\mathrm{pH}$, standard units

Hardness as $\mathrm{CaCO}_{3}, \mathrm{mg} / \mathrm{l}$

Hardness, noncarbonate as $\mathrm{CaCO}_{3}, \mathrm{mg} / \mathrm{L}$

Bicarbonate as $\mathrm{HCO}_{3}, \mathrm{mg} / \mathrm{L}$

Calcium, dissolved as $\mathrm{Ca}, \mathrm{mg} / \mathrm{L}$

Magnesium, dissolved as $\mathrm{Mg}, \mathrm{mg} / \mathrm{L}$

Sodium, dissolved as $\mathrm{Na}, \mathrm{mg} / \mathrm{L}$

Potassium, dissolved as $\mathrm{K}, \mathrm{mg} / \mathrm{L}$

Sulfate, dissolved as $\mathrm{SO}_{4}, \mathrm{mg} / \mathrm{L}$ Chloride, dissolved as $\mathrm{Cl}, \mathrm{mg} / \mathrm{L}$

Fluoride, dissolved as $\mathrm{F}, \mathrm{mg} / \mathrm{L}$

Silica, dissolved as $\mathrm{SiO}_{2}, \mathrm{mg} / \mathrm{l}$

Solids, dissolved, mg/h

Nitrate, dissolved as $\mathrm{N}, \mathrm{mg} / \mathrm{L}$

Phosphate, total as $\mathrm{PO}_{4}, \mathrm{mg} / \mathrm{l}$

Boron, dissolved as $B, \mu g / L$

Iron, dissolved as $\mathrm{Fe}, \mu \mathrm{g} / \mathrm{L}$

Sediment, suspended, $\mathrm{mg} / \mathrm{L}$
247
85

85
22

22
12
12

12

12

12
12
12

12
12

12

12
12
12

12
12
12

12

12
12
9
3

225
1,10

$\begin{array}{cc}72 & 198 \\ 100 & 1,060 \\ 8.0 & 8.0 \\ 240 & 230 \\ 50 & 49 \\ & \\ 230 & 220 \\ 74 & 73 \\ 13 & 12 \\ 180 & 180 \\ 5 & 5 \\ & \\ 66 & 67 \\ 260 & 260 \\ .4 & .4 \\ 12 & 13 \\ 730 & 718 \\ & \\ .73 & .68 \\ .18 & .21 \\ 90 & 100 \\ 20 & 50 \\ 77 & 163\end{array}$
12,500

1,560

270

66

260
83

16

190

88
280

280.5

24
770

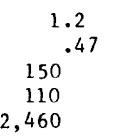

$\begin{array}{rr}0.90 & 862 \\ 152 & 247\end{array}$

7.2

190

25

170
54

9.1

140
4

49
200

.4
8.4

$610^{8.4}$

.01
$60^{.08}$
10

North Fork Ninnescah River at Cheney Dam

Streamf $10 w^{1}, \mathrm{ft}^{3} / \mathrm{s}$

Specific conductance, $\mu \mathrm{S} / \mathrm{cm}$ $\mathrm{pH}$, standard units

Hardness as $\mathrm{CaCO}_{3}, \mathrm{mg} / \mathrm{L}$

Hardness, noncarbonate as $\mathrm{CaCO}_{3}$, mg/L

Bicarbonate as $\mathrm{HCO}_{3}, \mathrm{mg} / \mathrm{L}$

Calcium, dissolved as $\mathrm{Ca}, \mathrm{mg} / \mathrm{L}$

Magnesium, dissolved as $\mathrm{Mg}, \mathrm{mg} / \mathrm{L}$

Sodium, dissolved as $\mathrm{Na}, \mathrm{mg} / \mathrm{L}$

Potassium, dissolved as $\mathrm{K}$, $\mathrm{mg} / \mathrm{L}$

Sulfate, dissolved as $\mathrm{SO}_{4}, \mathrm{mg} / \mathrm{l}$ Chloride, dissolved as $\mathrm{Cl}, \mathrm{mg} / \mathrm{L}$ Fluoride, dissolved as $\mathrm{F}, \mathrm{mg} / \mathrm{L}$

Silica, dissolved as $\mathrm{SiO}_{2}, \mathrm{mg} / \mathrm{l}$

Solids, dissolved, $\mathrm{mg} / \mathrm{l}$

\begin{tabular}{|c|c|c|c|c|c|}
\hline 65 & 0.43 & 155 & 1,600 & 0.13 & 369 \\
\hline 52 & 1,010 & 992 & 1,360 & 660 & 156 \\
\hline 44 & 7.8 & 7.8 & 8.5 & 7.1 & .3 \\
\hline 37 & 220 & 300 & 580 & 140 & 130 \\
\hline 37 & 100 & 140 & 370 & 17 & 120 \\
\hline 37 & 190 & 200 & 260 & 140 & 29 \\
\hline 37 & 58 & 78 & 150 & 38 & 32 \\
\hline 37 & 21 & 25 & 50 & 9.0 & 12 \\
\hline 37 & 88 & 95 & 160 & 39 & 34 \\
\hline 37 & 5 & 6 & 10 & 3 & 2 \\
\hline 37 & 80 & 120 & 280 & 35 & 77 \\
\hline 37 & 160 & 160 & 230 & 98 & 38 \\
\hline 37 & .4 & .4 & .5 & .2 & .1 \\
\hline 37 & 6.2 & 6.4 & 26 & 1.1 & 4.3 \\
\hline 37 & 590 & 586 & 840 & 350 & 115 \\
\hline
\end{tabular}


Table 6. Statistical summary of selected water-quality properties and constituents for major streams, October 1965-September 1985-.-Continued

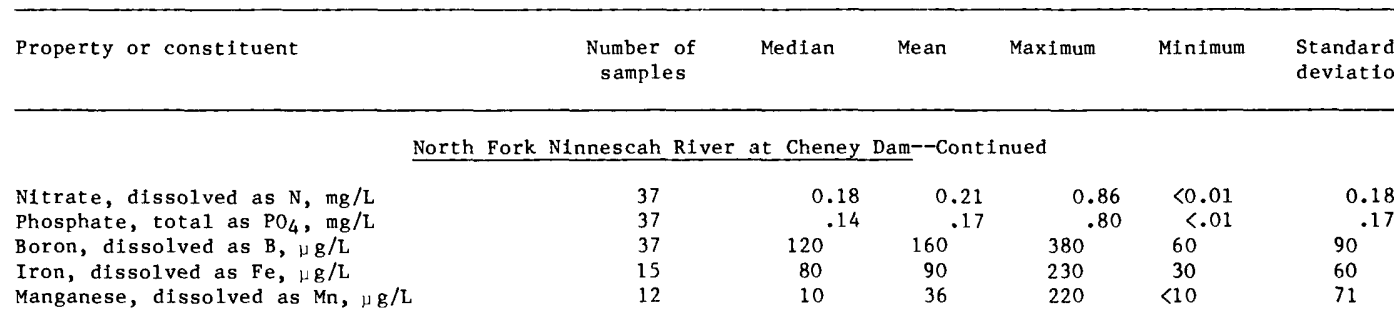

South Fork Ninnescah River near Murdock

Streamflow $\mathrm{ft}^{3} / \mathrm{s}$

Specific conductance, $\mu \mathrm{S} / \mathrm{cm}$

$\mathrm{pH}$, standard units

Hardness as $\mathrm{CaCO}_{3}, \mathrm{mg} / \mathrm{L}$

Hardness, noncarbonate as $\mathrm{CaCO}_{3}, \mathrm{mg} / \mathrm{L}$

$\begin{array}{rccccc}396 & 134 & 266 & 15,000 & 30 & 937 \\ 328 & 1,350 & 1,340 & 1,950 & 230 & 308 \\ 135 & 7.8 & 7.8 & 8.8 & 7.1 & .4 \\ 121 & 220 & 210 & 320 & 100 & 38 \\ 121 & 47 & 46 & 80 & 1 & 14 \\ 121 & 210 & 200 & 320 & 120 & 39 \\ 121 & 69 & 67 & 110 & 35 & 14 \\ 121 & 11 & 11 & 19 & 3.8 & 2.7 \\ 121 & 200 & 190 & 310 & 16 & 61 \\ 121 & 5 & 5 & 8 & 3 & 1 \\ 121 & 48 & 47 & 70 & 9.9 & 11 \\ 287 & 290 & 300 & 500 & 12 & 91 \\ 121 & .3 & .3 & .6 & .2 & .1 \\ 121 & 15 & 14 & 32 & 2.8 & 4.6 \\ 121 & 760 & 730 & 1,000 & 190 & 163 \\ & & & & & \\ 121 & .82 & .86 & 2.0 & .02 & .5 \\ 121 & .46 & .49 & 5.4 & .18 & .48 \\ 120 & 120 & 110 & 240 & 20 & 30 \\ 19 & 90 & 110 & 470 & <10 & 110 \\ 15 & <10 & 4 & 10 & <10 & <10 \\ 131 & 92 & 265 & 3,280 & 11 & 514\end{array}$

Bicarbonate as $\mathrm{HCO}_{3}, \mathrm{mg} / \mathrm{L}$

Calclum, dissolved as $\mathrm{Ca}, \mathrm{mg} / \mathrm{L}$

Magnestum, dissolved as $\mathrm{Mg}$, mg/

Sodium, dissolved as $\mathrm{Na}, \mathrm{mg} / \mathrm{L}$

Potassium, dissolved as $\mathrm{K}, \mathrm{mg} / \mathrm{L}$

Sulfate, dissolved as $\mathrm{SO}_{4}, \mathrm{mg} / \mathrm{h}$

Chloride, dissolved as $\mathrm{Cl}$, mg/L

Fluoride, dissolved as $\mathrm{F}, \mathrm{mg} / \mathrm{L}$

Silica, dissolved as $\mathrm{SiO}_{2}, \mathrm{mg} / \mathrm{L}$

Solids, dissolved, $\mathrm{mg} / \mathrm{L}$

Nitrate, dissolved as $\mathrm{N}, \mathrm{mg} / \mathrm{L}$

Phosphate, total as $\mathrm{PO}_{4}, \mathrm{mg} / \mathrm{L}$

Boron, dissolved as $B, \mu g / L$

Iron, dissolved as $\mathrm{Fe}, \mu \mathrm{g} / \mathrm{L}$

Manganese, dissolved as $\mathrm{Mn}, \mu \mathrm{g} / \mathrm{L}$

Sediment, suspended, $\mathrm{mg} / \mathrm{L}$

$92 \quad 265 \quad 3,280$

514

Streamflow ${ }^{1}, \mathrm{ft}^{3 / 5}$

Specific conductance, ${ }_{11} \mathrm{~S} / \mathrm{cm}$

$\mathrm{pH}$, standard units

Hardness as $\mathrm{CaCO}_{3}, \mathrm{mg} / \mathrm{t}$

Hardness, noncarbonate as $\mathrm{CaCO}_{3}, \mathrm{mg} / \mathrm{t}$

Bicarbonate as $\mathrm{HCO}_{3}, \mathrm{mg} / \mathrm{L}$

Calcium, dissolved as $\mathrm{Ca}, \mathrm{mg} / \mathrm{L}$

Magnesium, dissolved as $\mathrm{Mg}, \mathrm{mg} / \mathrm{L}$

Sodium, dissolved as $\mathrm{Na}, \mathrm{mg} / \mathrm{L}$

Potassium, dissolved as $\mathrm{K}, \mathrm{mg} / \mathrm{L}$

Sulfate, dissolved as $\mathrm{SO}_{4}, \mathrm{mg} / \mathrm{L}$ Chloride, dissolved as $\mathrm{Cl}, \mathrm{mg} / \mathrm{L}$ Fluoride, dissolved as $\mathrm{F}, \mathrm{mg} / \mathrm{L}$

Silica, dissolved as $\mathrm{SiO}_{2}, \mathrm{mg} / \mathrm{L}$

Solids, dissolved, $\mathrm{mg} / \mathrm{L}$

Nitrate, dissolved as $\mathrm{N}, \mathrm{mg} / \mathrm{L}$ Phosphate, total as $\mathrm{PO}_{4}, \mathrm{mg} / \mathrm{L}$ Arsenic, dissolved as As,

Boron, dissolved as $B$, $1 \mathrm{~g} / \mathrm{L}$.

Cadmium, dissolved as $\mathrm{Cd}, \mu \mathrm{g} / \mathrm{t}$

Chromium, total as $\mathrm{Cr}, \mu \mathrm{g} / \mathrm{L}$

Iron, dissolved as $\mathrm{Fe}, 1, \mathrm{~g} / \mathrm{L}$

Lead, dissolved as $\mathrm{Pb}$,, $\mathrm{g} / \mathrm{L}$

Manganese, dissolved as $\mathrm{Mn}, \mathrm{g} / \mathrm{L}$

Mercury, total as $\mathrm{Hg}, \mathrm{g} / \mathrm{L}$

Zinc, dissolved as $\mathrm{Zn}, \mathrm{g} / \mathrm{L}$

Sediment, suspended, $\mathrm{mg} / \mathrm{t}$

Ninnescah River near Peck

\begin{tabular}{|c|c|c|c|c|c|}
\hline 233 & 170 & 787 & 31,800 & 23 & 2,820 \\
\hline 179 & 1,110 & 1,080 & 1,740 & 170 & 324 \\
\hline 149 & 7.7 & 7.7 & 8.5 & 6.8 & .4 \\
\hline 128 & 220 & 220 & 320 & 48 & 48 \\
\hline 128 & 54 & 52 & 110 & 0 & 18 \\
\hline 128 & 200 & 200 & 300 & 56 & 44 \\
\hline 128 & 62 & 63 & 99 & 14 & 15 \\
\hline 128 & 15 & 14 & 22 & 3.2 & 3.8 \\
\hline 128 & 150 & 150 & 270 & 7.5 & 56 \\
\hline 128 & 5 & 5 & 8 & 2 & 1 \\
\hline 128 & $5 i$ & 55 & 82 & 6.0 & 15 \\
\hline 129 & 230 & 230 & 420 & 12 & 89 \\
\hline 127 & .4 & .4 & .7 & .2 & .1 \\
\hline 127 & 11 & 12 & 28 & 1.0 & 4.5 \\
\hline 127 & 640 & 627 & 920 & 84 & 174 \\
\hline 128 & .54 & .64 & 2.0 & $<.01$ & .43 \\
\hline 119 & .40 & .62 & 23 & $<.01$ & 2.1 \\
\hline 1 & -- & - & $<1$ & -- & -- \\
\hline 118 & 120 & 120 & 260 & 30 & 30 \\
\hline 1 & -- & - & $<1$ & -- & -- \\
\hline 1 & -- & - & 4 & -- & -- \\
\hline 19 & 80 & 90 & 190 & 20 & 40 \\
\hline 1 & -- & -- & $<1$ & - & -- \\
\hline 15 & $<10$ & 4 & 10 & $<10$ & 5 \\
\hline 1 & -- & -- & 4.3 & -- & -- \\
\hline 1 & -- & -- & 65 & -- & -- \\
\hline 135 & 87 & 232 & 2,190 & 11 & 380 \\
\hline
\end{tabular}

1 Instantaneous streamflow measured in conjunction with the collection of water-quality data.

2 Water-quality constituents, for which 12 samples are available, were collected during streamflows that ranged only from 10 to $250 \mathrm{ft}^{3} / \mathrm{s}$. However, the median streamflow measured during collection of the samples was approximately equivalent to the long-term median streamflow. 
predominant if their maximum concentrations exceed those of calcium and bicarbonate. The median concentration of suspended sediment $(745 \mathrm{mg} / \mathrm{L})$ is the largest for the major streams in Sedgwick County. Relatively large concentrations of suspended sediment occur in the Little Arkansas River because much of the streamflow is provided by surface runoff from loess-mantled upland areas in McPherson and Harvey Counties.

Water-quality characteristics of the Arkansas River at Derby are somewhat different from those at the Arkansas River at Hutchinson primarily because of streamflow contributed by the Little Arkansas River, ground-water inflow in the reach between the confluence of the Arkansas and Little Arkansas Rivers and Derby, and effluent from Wichita sewage-treatment plants. The water has a median hardness concentration of $370 \mathrm{mg} / \mathrm{L}$ as calcium carbonate and a median dissolved-solids concentration of $1,200 \mathrm{mg} / \mathrm{L}$. Sodium (median concentration, 300 $\mathrm{mg} / \mathrm{L}$ ) and chloride (median concentration, 380 $\mathrm{mg} / \mathrm{L}$ ) are the principal dissolved constituents. Median concentrations of these constituents and most of the other constituents are intermediates of median concentrations in the Arkansas River near Hutchinson and the Little Arkansas River at Valley Center. Maximum concentrations of nitrate as nitrogen $(13 \mathrm{mg} / \mathrm{L})$ and phosphate $(55$ $\mathrm{mg} / \mathrm{L}$ ) are much larger than those at the other streamflow-gaging stations and probably result from Wichita sewage-treatment plant effluent.

Water-quality data are relatively few for the North Fork Ninnescah River above Cheney Reservoir, and most of the data (those constituents with 12 samples) represent a range in streamflow from about 10 to 250 cubic feet per second. However, the median streamflow of about 72 cubic feet per second that occurred during collection of the 12 samples is equivalent to the median streamflow represented by the flow-duration curves (fig. 9). The water has a median hardness concentration of $240 \mathrm{mg} / \mathrm{L}$ as calcium carbonate and a median dissolved-solids concentration of $730 \mathrm{mg} / \mathrm{L}$. Sodium (median concentration, $180 \mathrm{mg} / \mathrm{L}$ ) and chloride (median concentration, $260 \mathrm{mg} / \mathrm{L}$ ) are the principal dissolved constituents. Most of the sodium and chloride are contributed by ground water discharged from Permian shale in southeastern
Stafford, northeastern Pratt, and southwestern Reno Counties, where the head-waters of the North Fork Ninnescah River are located. This area is the same general area that contributes saline water to the Arkansas River. Waterquality data for specific conductance and suspended sediment correspond to the full range of streamflow shown on the flow-duration curve (fig. 9) and should be representative of all flow conditions.

Water-quality characteristics of the North Fork Ninnescah River at Cheney Dam are affected primarily by Cheney Reservoir. As indicated by the flow-duration curve (fig. 9), streamflow that is equaled or exceeded more than 28 percent of the time is provided by local ground-water inflow because water is not being released from the reservoir. The water has a median hardness concentration of $220 \mathrm{mg} / \mathrm{L}$ as calcium carbonate and a median dissolved-solids concentration of $590 \mathrm{mg} / \mathrm{L}$. Sodium (median concentration, $88 \mathrm{mg} / \mathrm{L}$ ) and chloride (median concentration, $160 \mathrm{mg} / \mathrm{L}$ ) are the principal dissolved constituents, but their median concentrations are much less than those upstream from the reservoir.

Water in the South Fork Ninnescah River near Murdock has a median hardness concentration of $220 \mathrm{mg} / \mathrm{L}$ as calcium carbonate and a median dissolved-solids concentration of $760 \mathrm{mg} / \mathrm{L}$. Sodium (median concentration, 200 $\mathrm{mg} / \mathrm{L}$ ) and chloride (median concentration, 290 $\mathrm{mg} / \mathrm{L}$ ) are the principal dissolved constituents. The source of sodium and chloride is saline ground water that is discharged from Permian shale into the river in the vicinity of the PrattKingman County line (Hargadine and Luehring, 1978). On the basis of available data, median concentrations of water-quality properties and constituents occurring in the South Fork Ninnescah River near Murdock are very similar to those in the North Fork Ninnescah River above Cheney Reservoir.

Water quality in the Ninnescah River near Peck is slightly less mingralized than that observed in either the NorthiFork Ninnescah River above Cheney Reservoir or the South Fork Ninnescah River near Murdock. The water has a median hardness concentration of $220 \mathrm{mg} / \mathrm{L}$ as calcium carbonate and a median dissolved-solids concentration of $640 \mathrm{mg} / \mathrm{L}$. Sodium (median 


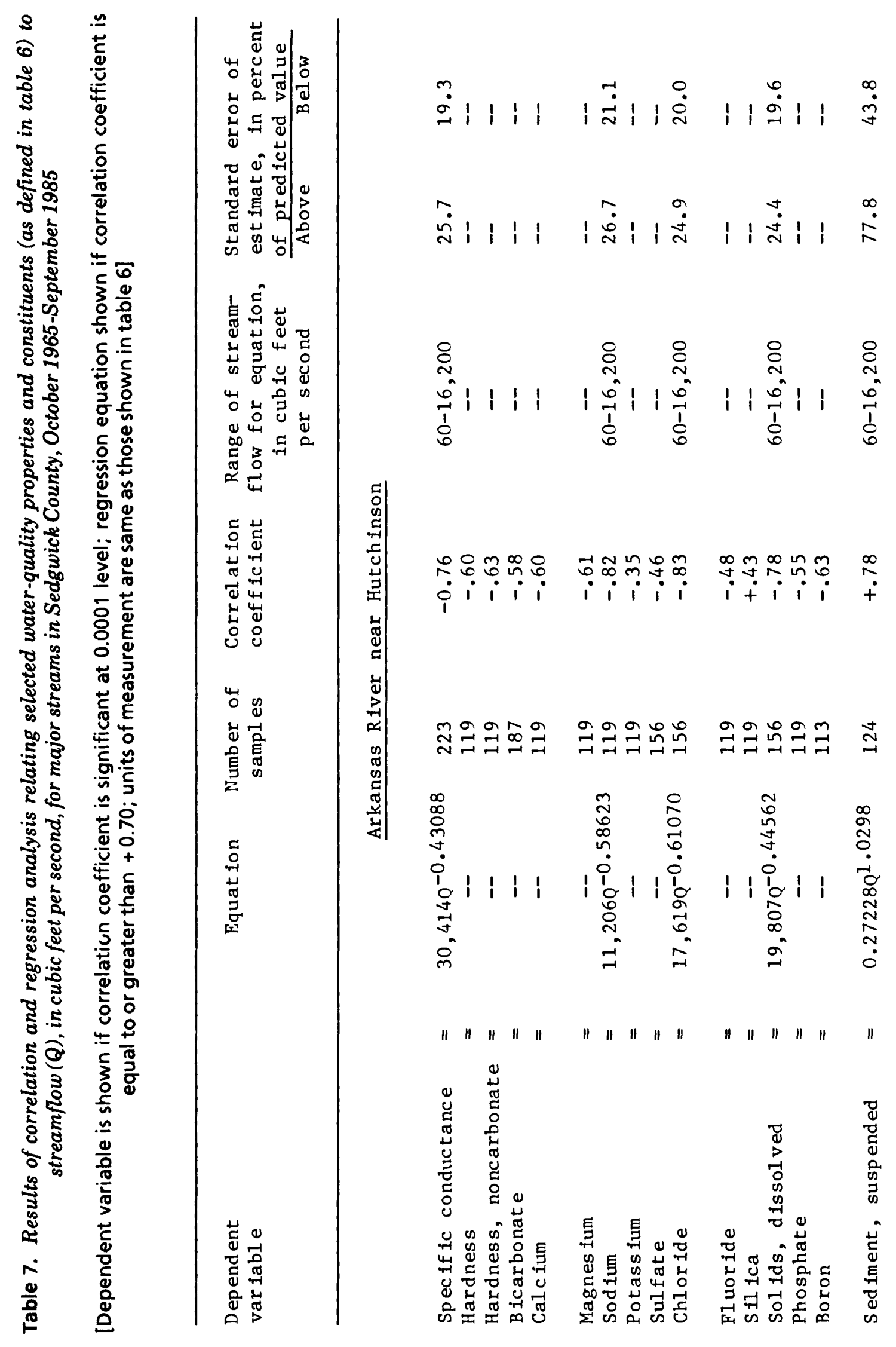




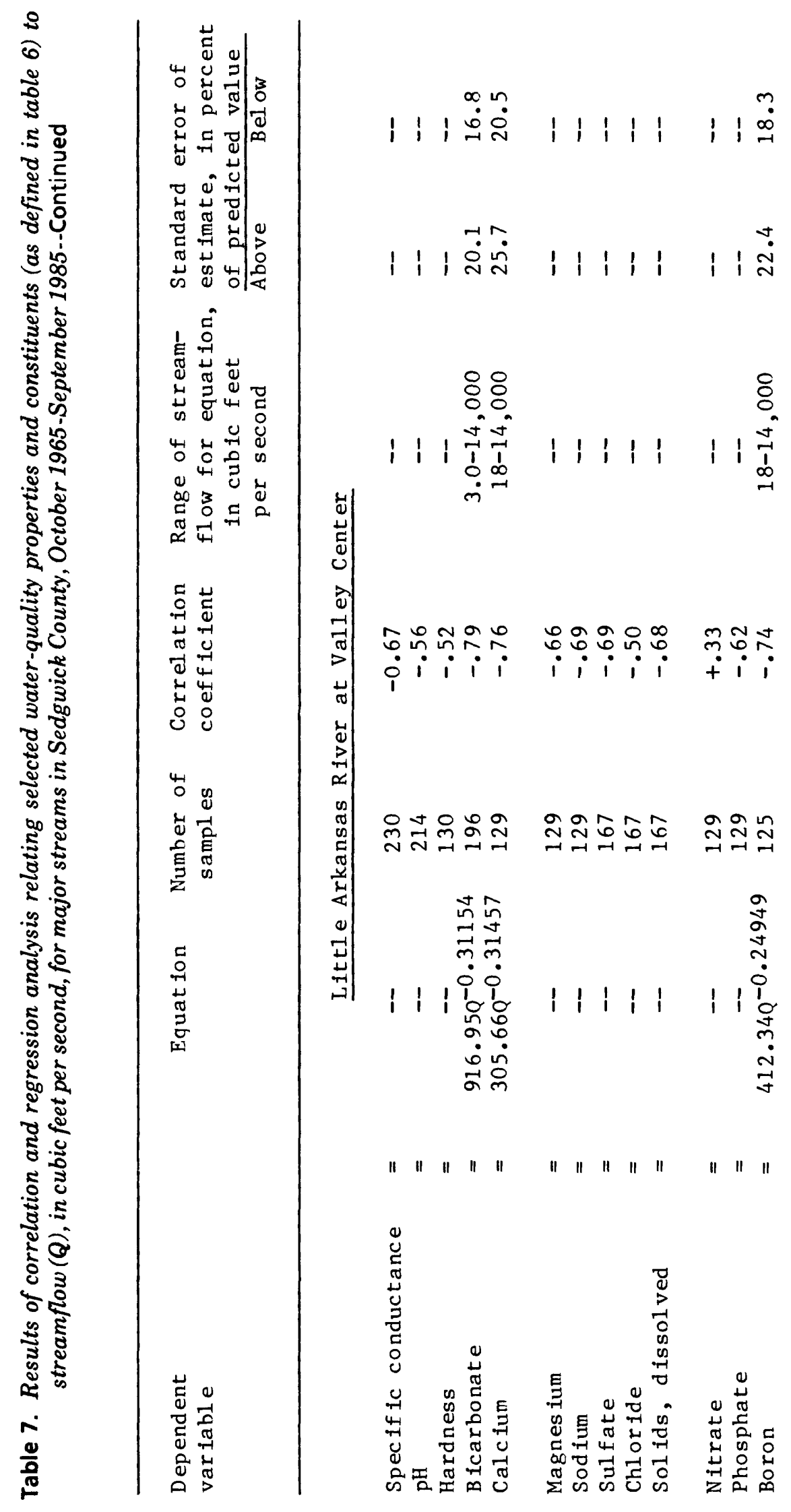


0
0
0
$\frac{0}{0}$

乛ี

造

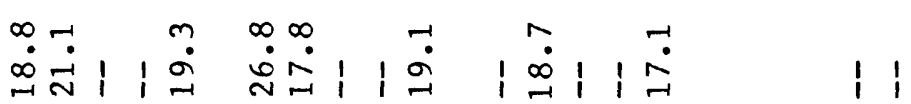

ஸ்̃

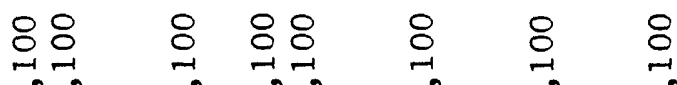

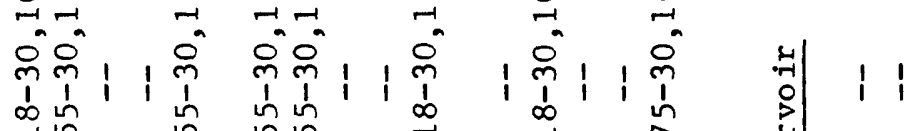

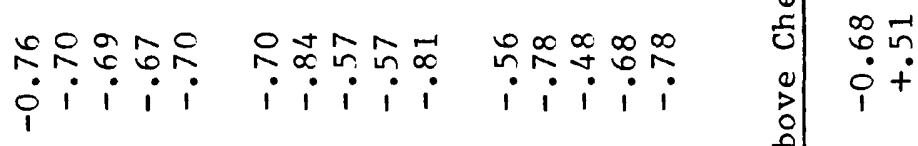

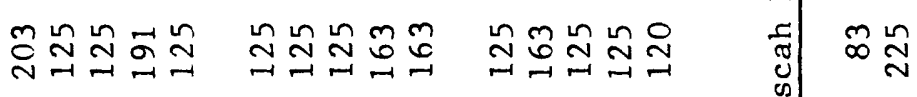

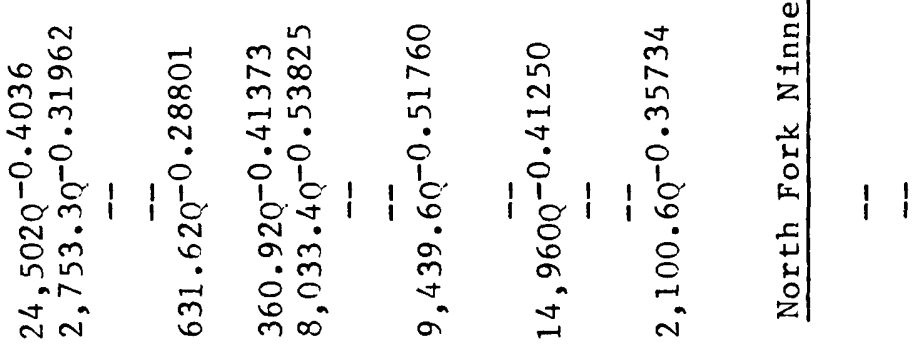

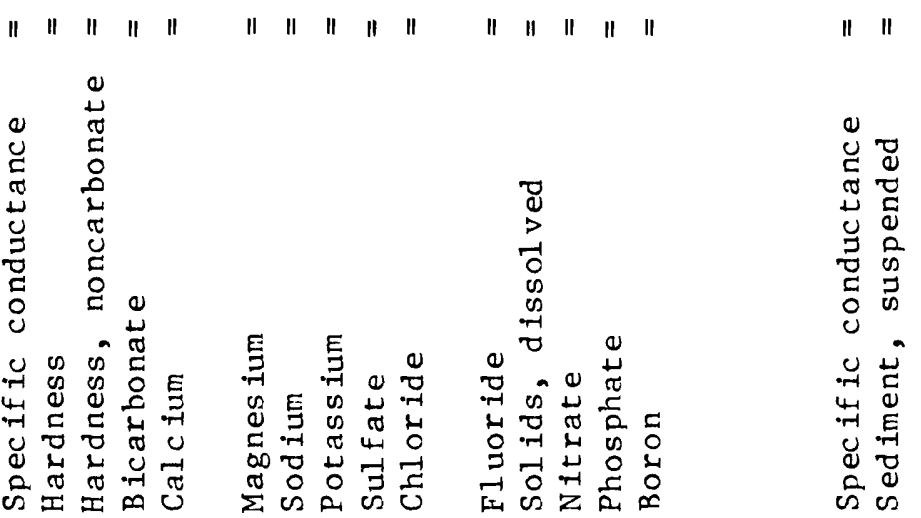




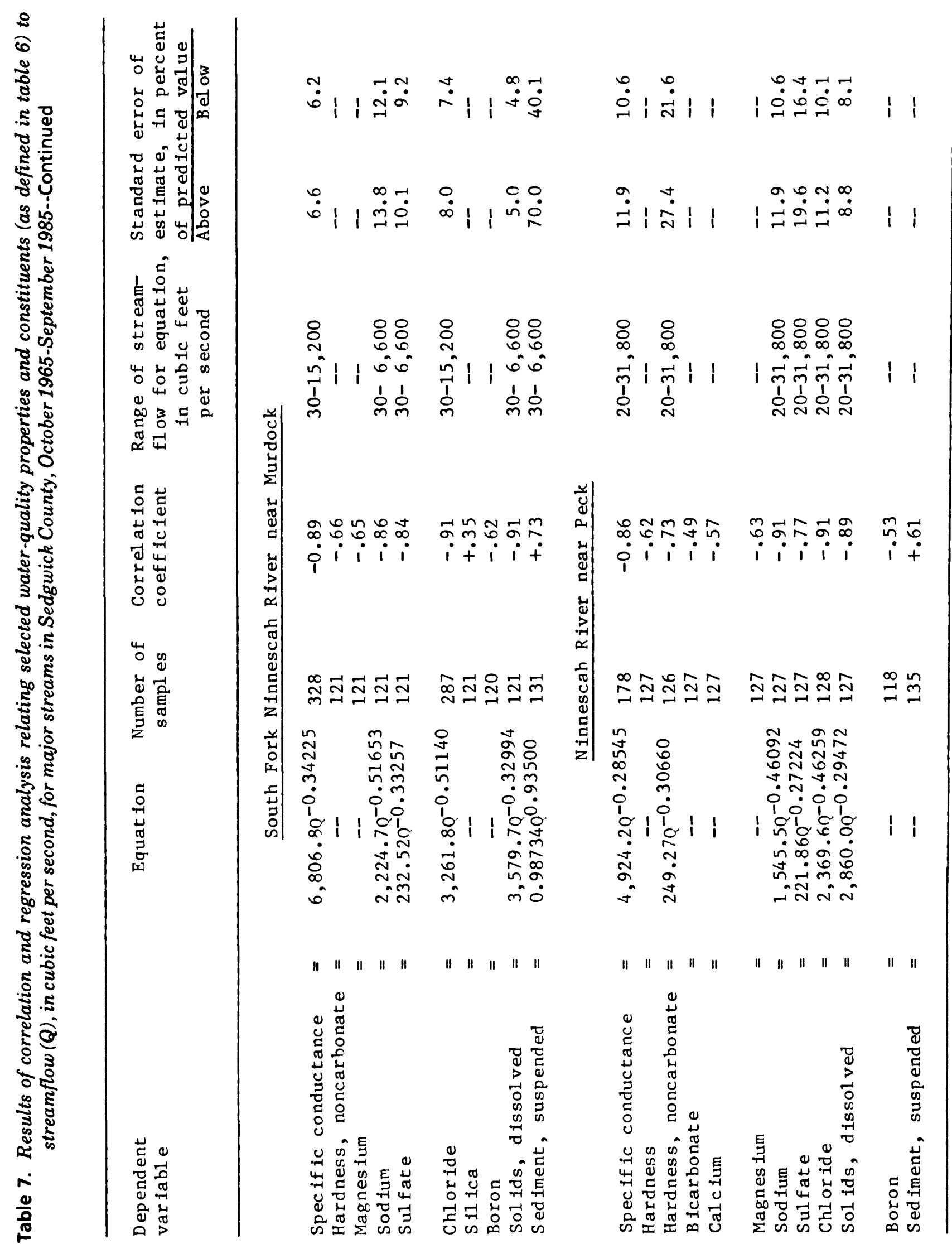


concentration, $150 \mathrm{mg} / \mathrm{L}$ ) and chloride (median concentration, $230 \mathrm{mg} / \mathrm{L}$ ) are the principal dissolved constituents. The decreased concentrations of sodium, chloride, and dissolved solids that occur in the Ninnescah River near Peck relative to those that occur in the North Fork Ninnescah River above Cheney Reservoir and the South Fork Ninnescah River near Murdock probably result from dilution by local ground-water discharge and releases from Cheney Reservoir.

Results of trend analysis for dissolvedsolids concentrations in the Arkansas River near Hutchinson and the Ninnescah River near Peck for 1968-82 indicate no apparent trend (Stoner, 1985). However, this period of record is after the completion of Cheney Reservoir.

Relationships between streamflow and waterquality properties and constituents

Correlation and regression analyses were performed on the data presented in the preceding "Statistical Summary" section to evaluate and develop relationships between streamflow and water-quality properties and constituents. The results of the correlation and regression analyses are given in table 7. Streamflow, in cubic feet per second, was designated as the independent variable, and the water-quality properties and constituents were designated as dependent variables. The properties and constituents listed in table 7 are those which are correlated with streamflow at the 0.0001 level of significance, as determined by an F-test. There were no significant correlations between streamflow and water-quality properties and constituents for the Ninnescah River at Cheney Dam because the streamflow is provided primarily by releases from Cheney Reservoir.

The square of a correlation coefficient, $R^{2}$, is that part of the variance of the dependent variable that is explained by or due to variance of the independent variable. A correlation coefficient, $R$, of \pm 0.70 means that 49 percent $(0.7 \times 0.7=49$ percent $)$ of the variance of the water-quality property or constituent is due to the variance of streamflow. The sign ( + or - ) of a correlation coefficient indicates whether the independent and dependent variables are directly or inversely related. If the correlation coefficient is positive $(+)$, the variables are directly related, or as streamflow increases the value of the dependent variable also increases. If the correlation coefficient is negative $(-)$, the variables are inversely related, or as streamflow increases the value of the dependent variable decreases.

Water-quality properties and constituents that are introduced into streams by surface runoff are positively correlated with streamflow. Properties and constituents that are introduced into a stream by ground-water discharge or point sources, such as effluent from sewage-treatment plants, are negatively correlated with streamflow because of dilution during surface runoff.

Nearly all of the dissolved constituents and properties that are directly related to concentrations of dissolved constituents (specific conductance, hardness, and noncarbonate hardness) in the major streams of Sedgwick County are negatively correlated with streamflow, indicating that they are introduced into the streams primarily by ground-water discharge. Exceptions are silica $\left(\mathrm{SiO}_{2}\right)$, which is positively correlated with streamflow in the Arkansas River near Hutchinson and the South Fork Ninnescah River near Murdock, and nitrate $\left(\mathrm{NO}_{3}\right)$, which is positively correlated with streamflow in the Little Arkansas River at Valley Center.

Suspended sediment is positively correlated with streamflow at all sites with available data. Suspended sediment is introduced into streams by surface runoff and is also increased by bank and channel erosion during high streamflow.

Regression equations presented in table 7 are of the form:

$$
Y=a Q^{b},
$$

where

$Y$ is the water-quality property or constituent, in units given in table 6;

$a \quad$ is the $Y$-intercept value, in units of $Y$;

$Q$ is streamflow, in cubic feet per second; and 
$b$ is the slope of the regression line, in $\log _{10}$ units.

Equations are given only for those relationships that were correlated at the 0.0001 level of significance and had correlation coefficients that were equal to or greater than \pm 0.70 .

Generally, specific conductance, dissolved solids and dissolved constituents that are major components of the dissolved-solids concentration, and suspended sediment were the only constituents that were correlated with streamflow to the degree required for developing regression equations. The ranges of streamflow for which the equations were developed and the standard errors of estimate that apply to predicting values of the dependent variables with the equations are also given in table 7.

Discharge of sodium, sulfate, chloride, dissolved solids, and suspended sediment

Discharges of major ions, dissolved solids, and suspended sediment are useful for estimating chemical and physical erosion of upstream basins. Except for the Little Arkansas River, the major streams have median concentrations of dissolved solids that exceed 500 $\mathrm{mg} / \mathrm{L}$ (table 6). In the Arkansas River, median concentrations of dissolved solids equal or exceed $1,200 \mathrm{mg} / \mathrm{L}$. These relatively large concentrations of dissolved solids are due to ground-water discharge with large concentrations of sodium, chloride, and occasionally, sulfate that enter the streams upstream from Sedgwick County. Although the median concentration of dissolved solids in the Little Arkansas River is less than $500 \mathrm{mg} / \mathrm{L}$, the median concentration of suspended sediment $(745 \mathrm{mg} / \mathrm{L})$ was larger than at any other site (table 6).

Regression equations relating streamflow (independent variable), in cubic feet per second, to instantaneous discharges of sodium, sulfate, chloride, dissolved solids, and suspended sediment (dependent variables), in tons per day, are presented in table 8 . These equations are of the same form as those presented in the preceding section. Instantaneous discharge of constituents was computed by multiplying the constituent concentration, in milligrams per liter, by the corresponding instantaneous streamflow, in cubic feet per second, and then multiplying by 0.0027 to convert to tons per day. Constituents (dependent variables) listed in table 8 were positively correlated (directly related) to streamflow at the 0.0001 level of significance, as determined by an F-test. Equations are given for those relationships that had correlation coefficients equal to or greater than +0.70 . Ranges of streamflow for which the equations were developed and standard errors that would result from using the equations for prediction purposes also are presented in table 8 .

Annual discharges of dissolved solids and suspended sediment were estimated by a computational procedure that utilized the regression equations in table 8 in conjunction with flow-duration curves (figs. 8 and 9) in the following manner:

(1) The regression equations were used to compute instantaneous discharges of constituents, in tons per day, for streamflows representing selected percentages of time on the flow-duration curves.

Discharges of constituents computed for the beginning and end of each time interval (period between each percentage of time and the succeeding percentage of time) were summed and divided by two to compute the mean discharge during each time interval.

(3) Mean constituent discharge for each time interval was multiplied by the percentage of time in that interval, expressed as a decimal, to compute discharge during the interval.

(4) Discharges of constituents for all time intervals then were summed to compute mean discharge, in tons per day.

(5) Mean discharge of constituents, in tons per day, then was multiplied by 365 to compute mean annual discharge. 


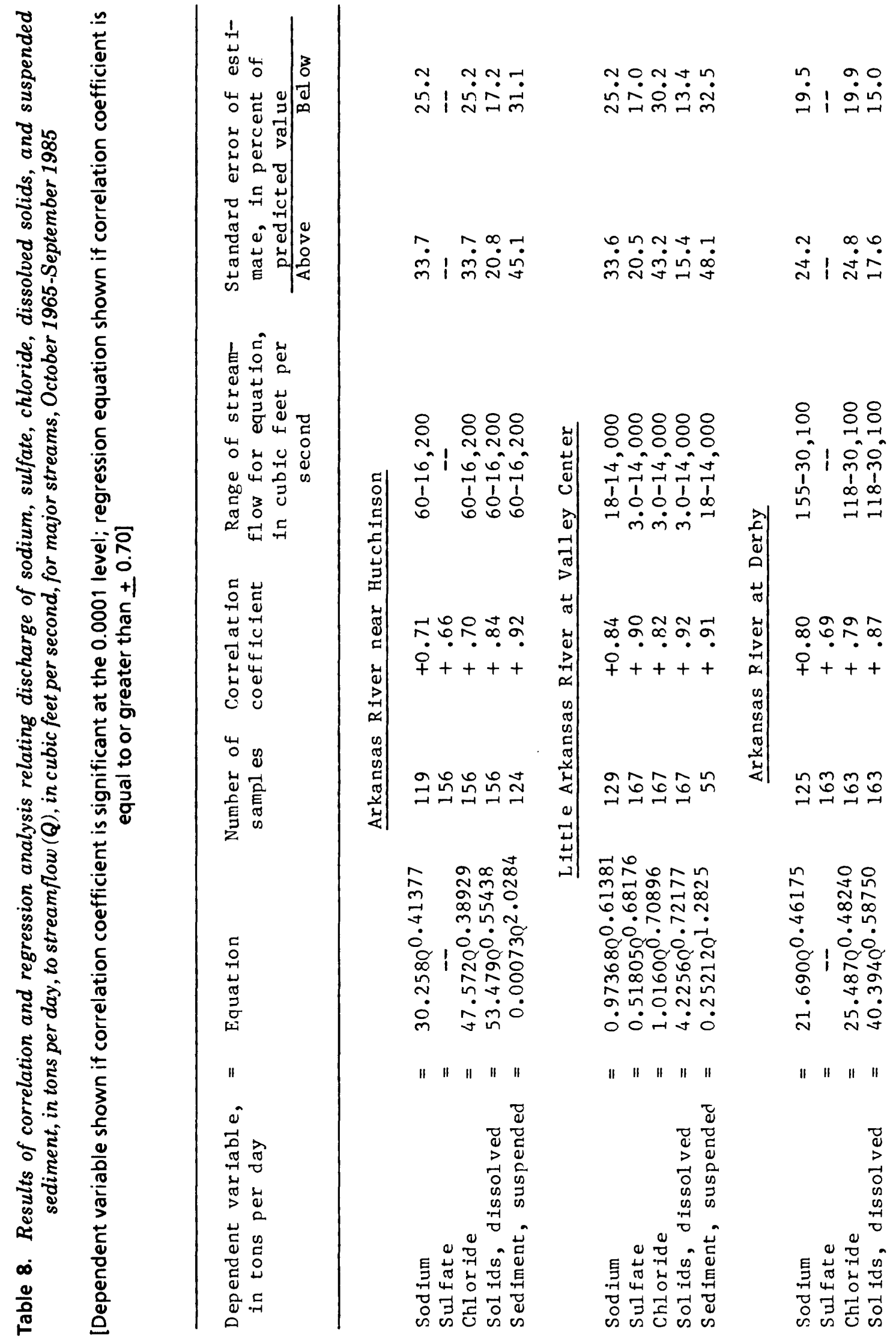




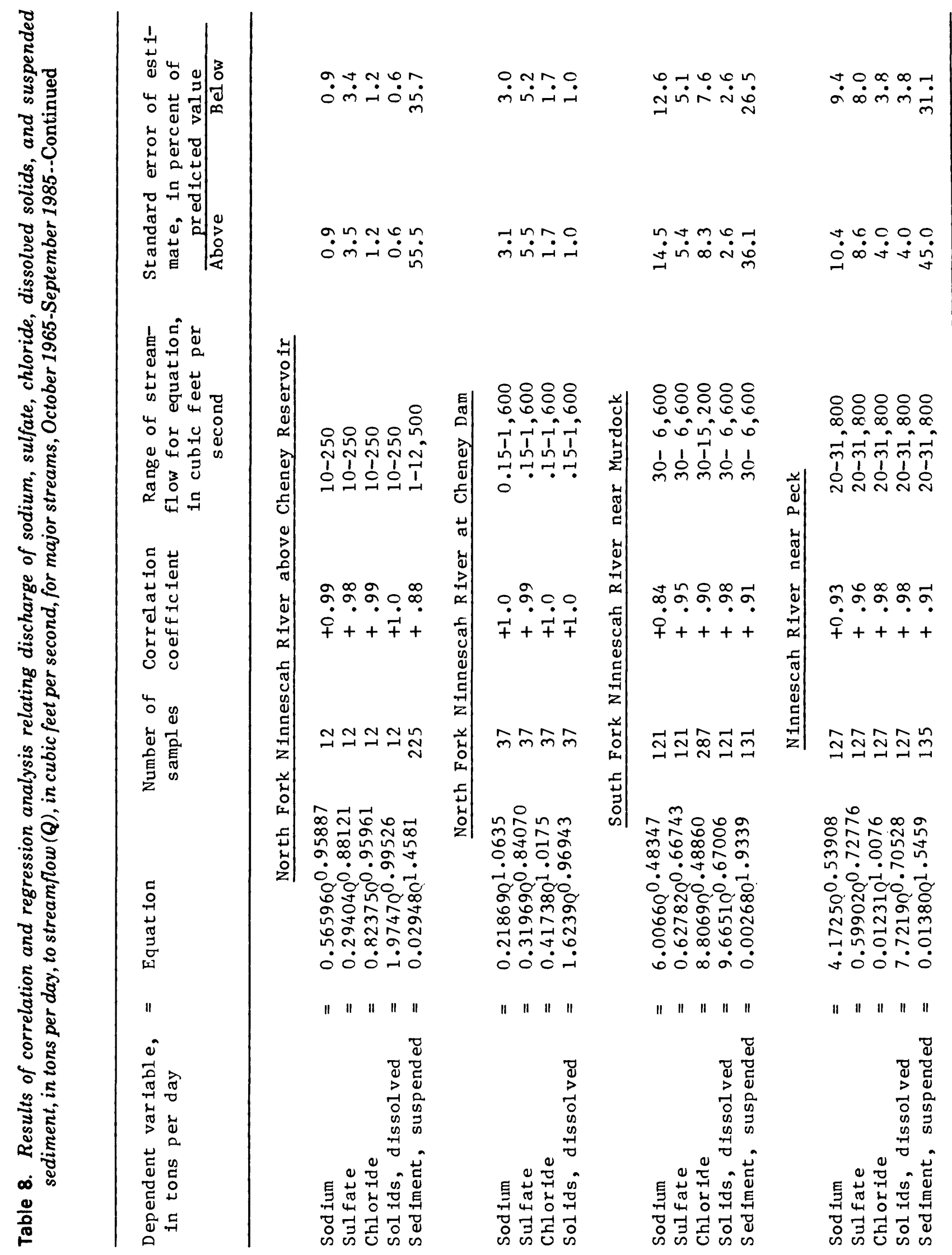


Table 9. Computation of mean suspended-sediment discharge for Arkansas River near Hutchinson, October 1965-September 1985

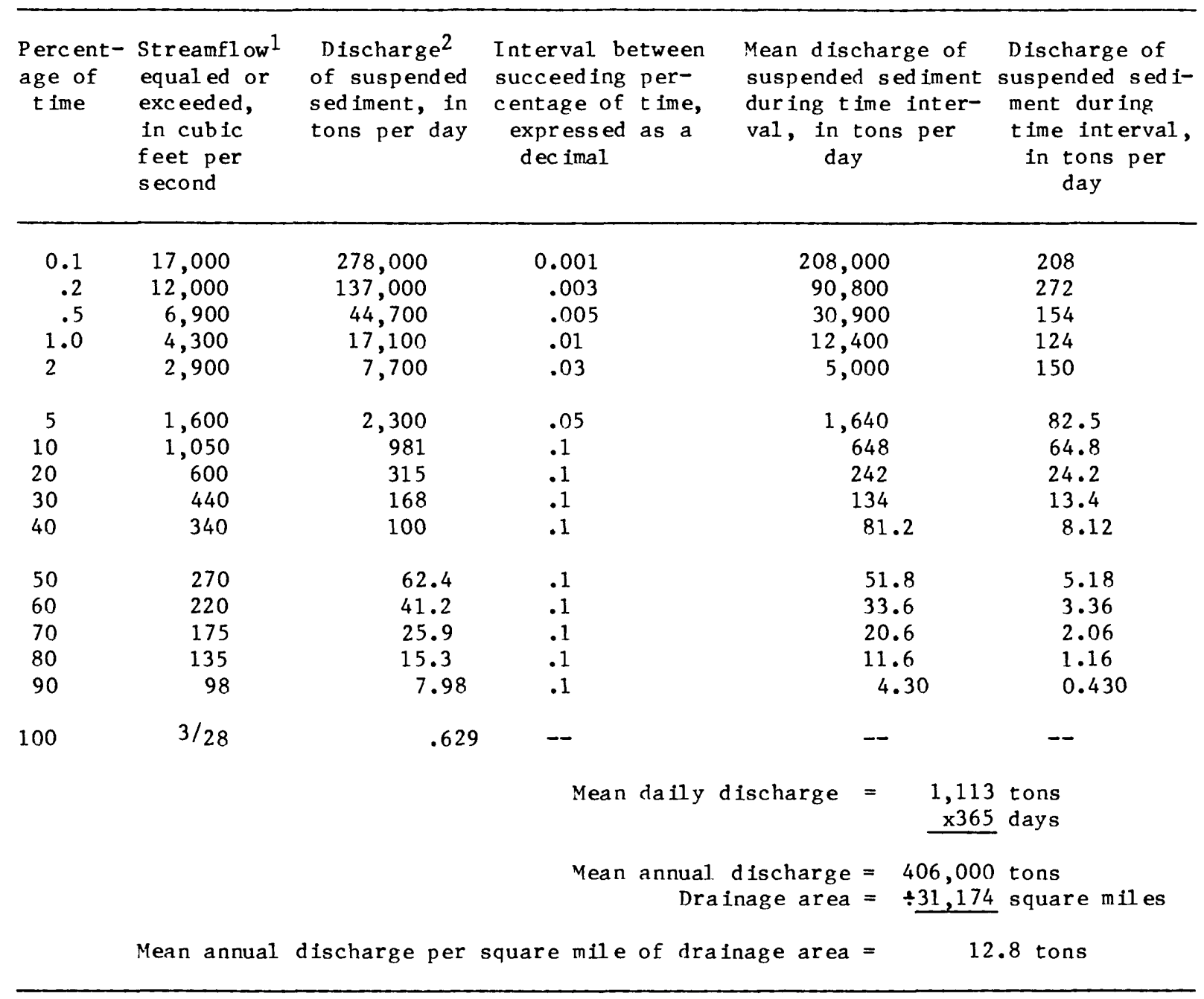

1 Streamflow from flow-duration curve in figure 8 .

2 Instantaneous value computed with regression equation in table 8 .

3 One day mean low-flow value with a recurrence interval of 20 years. 


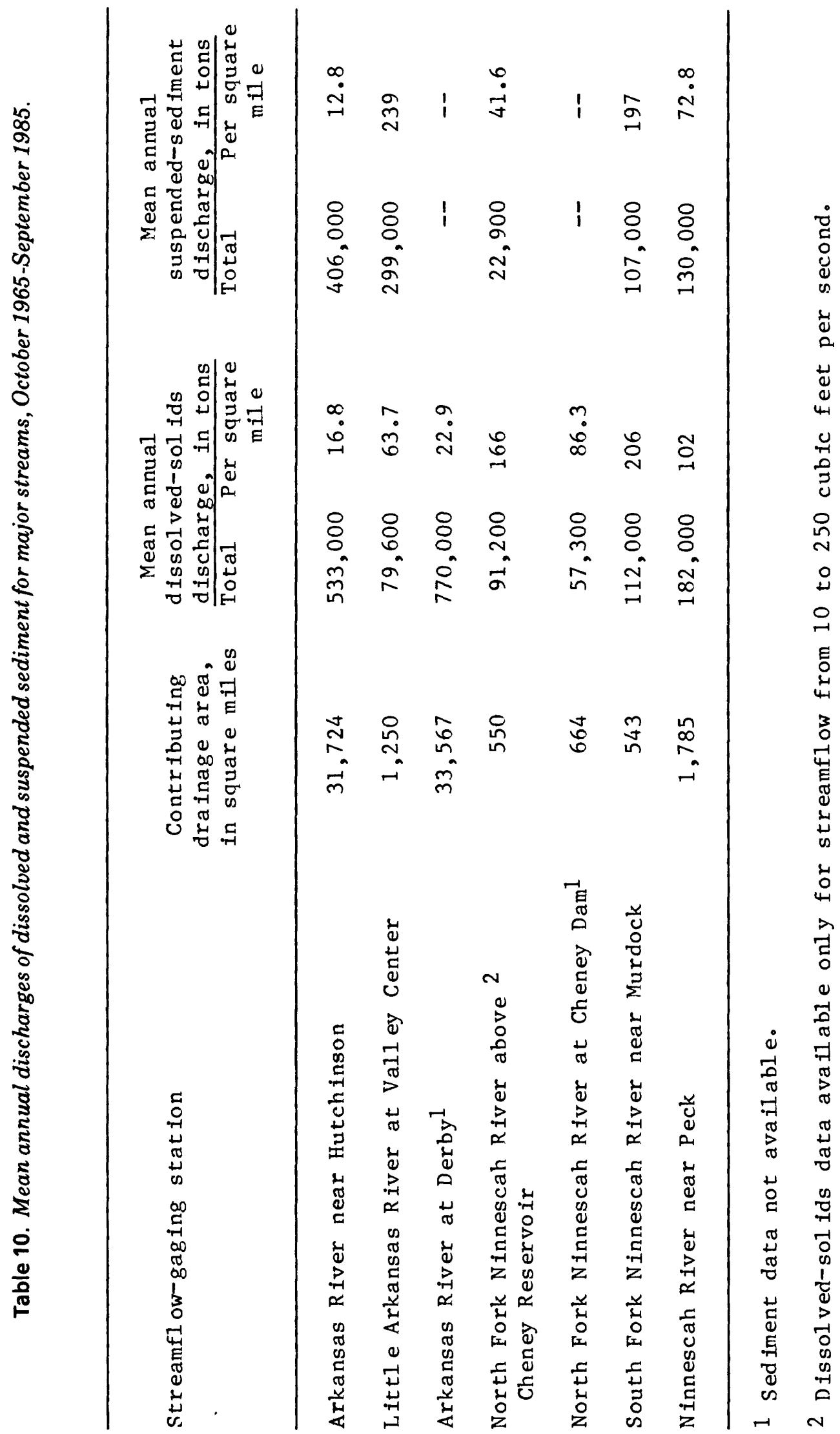


An example of this procedure, as used to compute mean annual suspended-sediment discharge for the Arkansas River near Hutchinson, is shown in table 9.

Mean annual discharges of dissolved solids and suspended sediment, in tons, for major streams are given in table 10. The Arkansas River has the largest mean annual discharges of dissolved solids (770,000 tons) at Derby and suspended sediment $(405,000$ tons $)$ near Hutchinson principally because it carries much more flow than the other streams. The North Fork Ninnescah River has the smallest mean annual discharge of dissolved solids (57,300 tons) at Cheney Dam and the smallest mean annual discharge of suspended sediment (22,900 tons) above Cheney Reservoir principally because the North Fork Ninnescah River has the smallest annual flow, especially at Cheney Dam because of the regulating effect of Cheney Reservoir (see "Flow Duration" section). The computed value of mean annual dissolved-solids discharge for the North Fork Ninnescah River above Cheney Reservoir is considered as a very rough estimate because the regression equation used to compute instantaneous discharges of dissolved solids was developed for streamflow that ranged from 10 to only 250 cubic feet per second.

Estimates of rates of chemical and physical erosion were developed by dividing the mean annual discharges of dissolved solids and suspended sediment by the contributing drainage areas of the streams. These estimates are given also in table 10. The Arkansas River basin upstream of Hutchinson has the smallest annual rates of chemical and physical erosion, yielding an average of 16.8 tons of dissolved solids per square mile and 12.8 tons of suspended sediment per square mile, principally because of the relatively small quantities of precipitation and resultant streamflow that occur in this basin in eastern Colorado and western Kansas. The South Fork Ninnescah River basin (206 tons of dissolved solids per square mile) and the North Fork Ninnescah River basin upstream of Cheney Reservoir (166 tons of dissolved solids per square mile) have the largest rates of chemical erosion, which occur predominantly in Permian rocks west of Sedgwick County. The Little Arkansas River basin (239 tons of suspended sediment per square mile) and the South Fork Ninnescah River basin (197 tons of suspended sediment per square mile) have the largest rates of physical erosion probably because of extensive loess deposits in upland areas of their basins.

Results of low-flow water-quality reconnaissance

Water samples for water-quality analysis were collected during low flow at 52 stream sites (plate 1) in Sedgwick County on March 11-14, 1985. These samples were collected in addition to concurrent streamflow measurements discussed in the "Streamflow Characteristics" section. The purpose of the low-flow waterquality survey was to provide information about the water-quality characteristics of streams as they relate to geology and human activities (sewage-treatment plant effluent and contamination from oilfield activities, for example). The streams were sampled during low flow so that geologic and human effects would not be obscured by dilution from surface runoff. The chemical analyses of these water samples are presented in table 11.

The column in table 11 that is labeled "local identifier" provides the location of the sampling sites according to a modification of the U.S.Bureau of Land Management's system of land subdivision. The first pair of numbers is the township south (S) of the 40th parallel; the second pair of numbers is the range east $(E)$ or west (W) of the sixth principal meridian; and the third set of numbers indicates the section (1-36). The letters following the section number designate the part of the section in which the site is located. The first letter denotes the quarter section (160-acre tract), the second letter denotes the quarter-quarter section $(40$-acre tract); and the third letter denotes the quarter-quarterquarter section (10-acre tract). The letters A, B, $\mathrm{C}$, or $\mathrm{D}$, divide each quarter, quarter-quarter, and quarter-quarter-quarter section into four equal parcels with the letter $A$ designating the northeast quarter, $B$ designating the northwest quarter, $\mathrm{C}$ designating the southwest quarter, and $\mathrm{D}$ designating the southeast quarter. This system is illustrated in figure 14, which depicts the location of site 27S-02E-36ADA.

Pie diagrams illustrating the range of dissolved-solids concentrations and proportions of major dissolved ions (based on milliequivalents per liter) in table 11 samples are plotted on plate 1 . 
Table 11. Streamflow and water-quality data collected during low-flow reconnaissance in Sedgwick County, March 11-14, 1985

\section{[A $<$ preceding a value indicates the constituent was not detected at that level]}

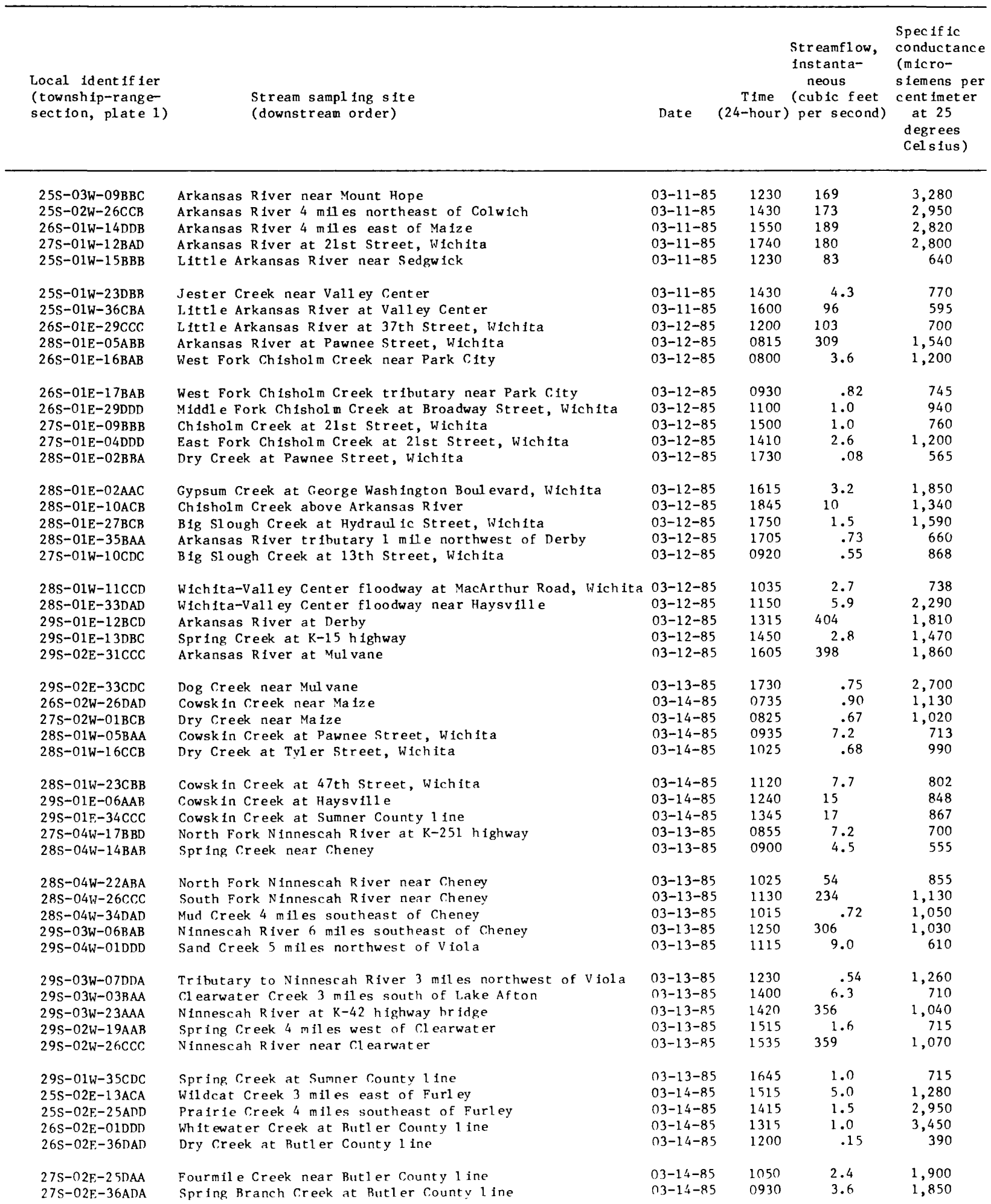


Table 11. Streamflow and water-quality data collected during low-flow reconnaissance in Sedgwick County, March 11-14, 1985--Continued

\begin{tabular}{|c|c|c|c|c|c|c|c|c|c|}
\hline $\begin{array}{l}\text { Local ident If ier } \\
\text { (townsh 1p-range- } \\
\text { sect fon, plate } 1 \text { ) }\end{array}$ & $\begin{array}{c}\mathrm{pH} \\
\text { (stand- } \\
\text { ard } \\
\text { units) }\end{array}$ & $\begin{array}{l}\text { Water } \\
\text { temper- } \\
\text { ature } \\
\text { (degrees } \\
\text { Celsius) } \\
\end{array}$ & $\begin{array}{l}\text { Hard- } \\
\text { ness, } \\
\text { (mill 1- } \\
\text { grams } \\
\text { per } \\
11 \text { ter } \\
\text { as } \mathrm{CaCO}_{3} \text { ) }\end{array}$ & $\begin{array}{l}\text { Hard- } \\
\text { ness, } \\
\text { noncar- } \\
\text { bonate } \\
\text { (mill i- } \\
\text { grams per } \\
\text { 1iter as } \\
\text { CaCO }_{3} \text { ) }\end{array}$ & $\begin{array}{l}\text { Calc ium, } \\
\text { dis- } \\
\text { solved } \\
\text { (milli- } \\
\text { grams } \\
\text { per } \\
\text { 1 iter } \\
\text { as Ca) }\end{array}$ & $\begin{array}{l}\text { Magne- } \\
\text { slum, } \\
\text { dis- } \\
\text { solved } \\
\text { (milli- } \\
\text { grams per } \\
1 \text { dter as } \\
\quad \text { Mg) }\end{array}$ & $\begin{array}{l}\text { Sodium, } \\
\text { dis- } \\
\text { solved } \\
\text { (milli- } \\
\text { grams } \\
\text { per } \\
\text { liter } \\
\text { as Na) }\end{array}$ & $\begin{array}{l}\text { Potas- } \\
\text { slum, } \\
\text { dis- } \\
\text { solved } \\
\text { (mill1- } \\
\text { grams } \\
\text { per } 1 \text { iter } \\
\text { as } K \text { ) }\end{array}$ & $\begin{array}{l}\text { Alka- } \\
1 \text { infty, } \\
\text { (mill 1- } \\
\text { grams } \\
\text { per } \\
1 \text { iter } \\
\text { as } \\
\mathrm{CaCO}_{3} \text { ) }\end{array}$ \\
\hline $25 \mathrm{~S}-03 \mathrm{~W}-09 \mathrm{BBC}$ & 8.3 & 16.0 & 350 & 150 & 100 & 24 & 520 & 6.4 & 200 \\
\hline $25 \mathrm{~S}-02 \mathrm{~W}-26 \mathrm{CCB}$ & 8.4 & 17.5 & 340 & 140 & 100 & 23 & 480 & 6.5 & 200 \\
\hline $26 \mathrm{~S}-01 \mathrm{~W}-14 \mathrm{DDB}$ & 8.4 & 15.0 & 340 & 130 & 100 & 23 & 450 & 6.7 & 210 \\
\hline $27 \mathrm{~s}-01 \mathrm{~W}-12 \mathrm{BAD}$ & 8.4 & 14.5 & 340 & 140 & 100 & 23 & 440 & 6.7 & 200 \\
\hline $25 \mathrm{~S}-01 \mathrm{~W}-15 \mathrm{BBB}$ & 7.9 & 14.5 & 220 & 67 & 64 & 14 & 43 & 6.5 & 150 \\
\hline $25 \mathrm{~S}-01 \mathrm{w}-23 \mathrm{DBB}$ & 8.6 & 15.0 & 350 & 92 & 98 & 26 & 40 & 4.6 & 260 \\
\hline $25 \mathrm{~s}-01 \mathrm{~W}-36 \mathrm{CBA}$ & 7.9 & 14.0 & 220 & 61 & 67 & 13 & 38 & 6.1 & 160 \\
\hline $26 \mathrm{~S}-01 \mathrm{E}-29 \mathrm{CCC}$ & 7.9 & 9.0 & 240 & 82 & 72 & 15 & 53 & 6.2 & 160 \\
\hline $28 \mathrm{~S}-01 \mathrm{E}-05 \mathrm{ABB}$ & 8.5 & 12.5 & 310 & 120 & 93 & 19 & 280 & 6.6 & 190 \\
\hline $26 \mathrm{~S}-01 \mathrm{E}-16 \mathrm{BAB}$ & 8.1 & 8.5 & 430 & 140 & 110 & 38 & 78 & 4.4 & 290 \\
\hline $26 \mathrm{~S}-01 \mathrm{E}-17 \mathrm{BAB}$ & 7.8 & 8.0 & 320 & 94 & 95 & 21 & 39 & 2.2 & 230 \\
\hline $26 \mathrm{~s}-01 \mathrm{E}-29 \mathrm{DDD}$ & 8.4 & 8.0 & 470 & 230 & 110 & 47 & 39 & 5.6 & 240 \\
\hline $27 \mathrm{~S}-01 \mathrm{E}-09 \mathrm{BBB}$ & 9.1 & 9.0 & 190 & 6 & 45 & 18 & 98 & 4.1 & 180 \\
\hline $27 \mathrm{~S}-01 \mathrm{E}-04 \mathrm{DDD}$ & 8.5 & 9.0 & 580 & 420 & 130 & 61 & 61 & 5.1 & 160 \\
\hline $28 \mathrm{~S}-01 \mathrm{E}-02 \mathrm{BBA}$ & 9.0 & 8.0 & 150 & 9 & 48 & 7.1 & 66 & 5.1 & 140 \\
\hline $28 \mathrm{~S}-01 \mathrm{E}-02 \mathrm{AAC}$ & 8.5 & 9.5 & 780 & 630 & 240 & 44 & 120 & 5.0 & 150 \\
\hline $28 \mathrm{~S}-01 \mathrm{E}-10 \mathrm{ACB}$ & 8.5 & 9.5 & 510 & 310 & 140 & 40 & 96 & 5.4 & 200 \\
\hline $28 \mathrm{~S}-01 \mathrm{E}-27 \mathrm{BCB}$ & 8.6 & 9.5 & 370 & 140 & 120 & 18 & 180 & 6.7 & 230 \\
\hline $28 \mathrm{~W}-01 \mathrm{E}-35 \mathrm{BAA}$ & 8.7 & 9.0 & 270 & 110 & 81 & 16 & 39 & 3.6 & 160 \\
\hline $27 \mathrm{~S}-01 \mathrm{~W}-10 \mathrm{CDC}$ & 8.2 & 10.5 & 130 & - & 41 & 7.8 & 130 & 3.8 & 150 \\
\hline $28 \mathrm{~S}-01 \mathrm{w}-11 \mathrm{CCD}$ & 8.3 & 8.0 & 150 & -- & 46 & 7.8 & 96 & 3.2 & 170 \\
\hline $28 \mathrm{~S}-01 \mathrm{E}-33 \mathrm{DAD}$ & 7.9 & 9.0 & 480 & 240 & 150 & 25 & 280 & 4.9 & 240 \\
\hline $29 S-01 E-12 B C D$ & 8.0 & 10.5 & 300 & 110 & 87 & 19 & 250 & 7.1 & 190 \\
\hline $29 \mathrm{~S}-01 \mathrm{E}-13 \mathrm{DBC}$ & 8.1 & 10.0 & 930 & 680 & 300 & 45 & 52 & 4.9 & 250 \\
\hline $29 S-02 E-31 C C C$ & 7.9 & 10.5 & 300 & 110 & 89 & 20 & 250 & 7.1 & 190 \\
\hline $29 \mathrm{~S}-02 \mathrm{E}-33 \mathrm{CDC}$ & 8.0 & 11.5 & 1,800 & 1,500 & 540 & 100 & 66 & 5.4 & 270 \\
\hline $26 \mathrm{~S}-02 \mathrm{~W}-26 \mathrm{DAD}$ & 8.3 & 7.0 & 240 & 67 & 72 & 14 & 140 & 8.2 & 170 \\
\hline $27 \mathrm{~S}-02 \mathrm{~W}-01 \mathrm{BCB}$ & 9.1 & 6.0 & 320 & 35 & 90 & 22 & 110 & 7.5 & 280 \\
\hline $28 \mathrm{~S}-01 \mathrm{~W}-05 \mathrm{BAA}$ & 8.1 & 8.0 & 200 & - & 62 & 12 & 69 & 5.3 & 220 \\
\hline $28 \mathrm{~S}-01 \mathrm{~W}-16 \mathrm{CCB}$ & 8.4 & 8.0 & 330 & 90 & 91 & 25 & 98 & 5.2 & 240 \\
\hline $28 \mathrm{~s}-01 \mathrm{w}-23 \mathrm{CBB}$ & 8.4 & 9.0 & 210 & - & 61 & 13 & 66 & 5.3 & 210 \\
\hline $29 \mathrm{~S}-01 \mathrm{E}-06 \mathrm{AAB}$ & 8.2 & 11.0 & 190 & -- & 58 & 12 & 93 & 4.4 & 200 \\
\hline $29 \mathrm{~S}-01 \mathrm{E}-34 \mathrm{CCC}$ & 8.0 & 12.0 & 210 & -- & 63 & 12 & 96 & 4.9 & 220 \\
\hline $27 \mathrm{~s}-04 \mathrm{~W}-17 \mathrm{BBD}$ & 8.3 & 7.5 & 200 & 47 & 54 & 15 & 64 & 3.2 & 150 \\
\hline $28 \mathrm{~S}-04 \mathrm{~W}-14 \mathrm{BAB}$ & 8.1 & 7.5 & 270 & 51 & 77 & 19 & 26 & 2.8 & 220 \\
\hline $28 \mathrm{~S}-04 \mathrm{~W}-22 \mathrm{ABA}$ & 8.3 & 7.5 & 240 & 51 & 65 & 19 & 84 & 4.0 & 190 \\
\hline $28 \mathrm{~S}-04 \mathrm{~W}-26 \mathrm{CCC}$ & 8.6 & 8.0 & 250 & 47 & 74 & 15 & 130 & 2.6 & 200 \\
\hline $28 \mathrm{~S}-04 \mathrm{~W}-34 \mathrm{DAD}$ & 8.3 & 7.5 & 410 & 130 & 77 & 54 & 83 & 3.0 & 280 \\
\hline $29 \mathrm{~S}-03 \mathrm{~W}-06 \mathrm{BAB}$ & 8.6 & 9.0 & 240 & 43 & 71 & 26 & 120 & 3.0 & 200 \\
\hline $29 \mathrm{~S}-04 \mathrm{~W}-01 \mathrm{DDD}$ & 8.3 & 8.5 & 240 & 57 & 57 & 23 & 42 & 2.3 & 180 \\
\hline $29 \mathrm{~S}-03 \mathrm{~W}-07 \mathrm{DDA}$ & 8.4 & 9.5 & 530 & 280 & 100 & 68 & 84 & 3.1 & 250 \\
\hline $29 \mathrm{~S}-03 \mathrm{~W}-03 \mathrm{BAA}$ & 8.0 & 9.5 & 310 & 93 & 84 & 25 & 34 & 4.1 & 220 \\
\hline $29 \mathrm{~S}-03 \mathrm{~W}-23 \mathrm{AAA}$ & 8.5 & 10.5 & 240 & 43 & 71 & 16 & 120 & 3.3 & 200 \\
\hline $29 \mathrm{~S}-02 \mathrm{~W}-19 \mathrm{AAB}$ & 8.3 & 13.0 & 300 & 82 & 73 & 29 & 41 & 6.0 & 220 \\
\hline $29 \mathrm{~S}-02 \mathrm{~W}-26 \mathrm{CCC}$ & 8.3 & 11.0 & 240 & 55 & 70 & 17 & 120 & 3.5 & 190 \\
\hline $29 \mathrm{~S}-01 \mathrm{~W}-35 \mathrm{CDC}$ & 8.7 & 12.0 & 280 & 71 & 73 & 24 & 45 & 3.9 & 210 \\
\hline $25 \mathrm{~S}-02 \mathrm{E}-13 \mathrm{ACA}$ & 8.3 & 11.0 & 660 & 460 & 170 & 56 & 38 & 4.2 & 200 \\
\hline $25 \mathrm{~S}-02 \mathrm{E}-25 \mathrm{ADD}$ & 8.1 & 12.0 & 1,500 & 1,200 & 430 & 93 & 160 & 3.4 & 240 \\
\hline $26 \mathrm{~S}-02 \mathrm{E}-01 \mathrm{DDD}$ & 7.9 & 12.0 & 1,300 & 1,100 & 390 & 86 & 250 & 3.8 & 250 \\
\hline $26 S-02 E-36 D A D$ & 8.1 & 8.0 & 190 & 40 & 58 & 11 & 8.7 & 6.1 & 150 \\
\hline $27 \mathrm{~S}-02 \mathrm{E}-25 \mathrm{DAA}$ & 8.0 & 9.5 & 1,000 & 790 & 320 & 52 & 64 & 3.8 & 220 \\
\hline $27 \mathrm{~S}-02 \mathrm{E}-36 \mathrm{ADA}$ & 7.6 & 9.5 & 1,000 & 780 & 320 & 48 & 53 & 3.3 & 220 \\
\hline
\end{tabular}


Table 11. Streamflow and water-quality data collected during low-flow reconnaissance in Sedgwick County, March 11-14,1985--Continued

\begin{tabular}{|c|c|c|c|c|c|c|c|}
\hline $\begin{array}{l}\text { Local ident if ier } \\
\text { (township-range- } \\
\text { section, plate } 1 \text { ) }\end{array}$ & $\begin{array}{l}\text { Sulfate, } \\
\text { dis- } \\
\text { solved } \\
\text { (milli- } \\
\text { grams per } \\
1 \text { iter as } \\
\mathrm{SO}_{4} \text { ) }\end{array}$ & $\begin{array}{l}\text { Chlo- } \\
\text { ride, } \\
\text { dis- } \\
\text { solved } \\
\text { (milli- } \\
\text { grams } \\
\text { per } 1 \text { iter } \\
\text { as } \mathrm{Cl} \text { ) }\end{array}$ & $\begin{array}{l}\text { Fluo- } \\
\text { ride, } \\
\text { dis- } \\
\text { solved } \\
\text { (milli- } \\
\text { grams } \\
\text { per liter } \\
\text { as F) }\end{array}$ & $\begin{array}{l}\text { Bromide, } \\
\text { dis- } \\
\text { solved } \\
\text { (mill i- } \\
\text { grams } \\
\text { per } \\
\text { liter } \\
\text { as } B r \text { ) }\end{array}$ & $\begin{array}{l}\text { Iodide, } \\
\text { dis- } \\
\text { solved } \\
\text { (milli- } \\
\text { grams } \\
\text { per } \\
\text { liter } \\
\text { as I) }\end{array}$ & $\begin{array}{l}\text { Sil ica, } \\
\text { dis- } \\
\text { solved } \\
\text { (mill } 1^{-} \\
\text {grams } \\
\text { per } \\
1 \text { iter } \\
\text { as } \mathrm{SiO}_{2} \text { ) }\end{array}$ & $\begin{array}{l}\text { Solids, } \\
\text { dissolved } \\
\text { sum of } \\
\text { const } 1^{-} \\
\text {tuents } \\
\text { (milli- } \\
\text { grams per } \\
1 \text { iter) }\end{array}$ \\
\hline $25 \mathrm{~s}-03 \mathrm{w}-09 \mathrm{BBC}$ & 200 & 780 & 0.5 & 0.19 & 0.015 & 12 & 1,760 \\
\hline $25 s-02 W-26 C C B$ & 190 & 730 & .5 & .19 & .011 & 12 & 1,660 \\
\hline $26 \mathrm{~S}-01 \mathrm{~W}-14 \mathrm{DDR}$ & 210 & 680 & .5 & .18 & .01 & 12 & 1,600 \\
\hline $27 \mathrm{~S}-01 \mathrm{~W}-12 \mathrm{BAD}$ & 200 & 660 & .5 & .18 & .012 & 11 & 1,560 \\
\hline $25 \mathrm{~S}-01 \mathrm{~W}-15 \mathrm{BBB}$ & 55 & 64 & .3 & .056 & .011 & 12 & 350 \\
\hline $25 \mathrm{~s}-01 \mathrm{~W}-23 \mathrm{DRB}$ & 120 & 31 & .3 & .012 & .006 & 10 & 490 \\
\hline $25 \mathrm{~s}-01 \mathrm{w}-36 \mathrm{CBA}$ & 57 & 54 & .3 & .055 & .007 & 12 & 340 \\
\hline $26 \mathrm{~S}-01 \mathrm{E}-29 \mathrm{CCC}$ & 66 & 74 & .3 & .094 & .009 & 12 & 400 \\
\hline $28 \mathrm{~S}-01 \mathrm{~F}-05 \mathrm{ARB}$ & 120 & 420 & .4 & .16 & .012 & 11 & 1,060 \\
\hline $26 \mathrm{~S}-01 \mathrm{E}-16 \mathrm{BAB}$ & 170 & 95 & .4 & .090 & .006 & 10 & 680 \\
\hline $26 \mathrm{~S}-01 \mathrm{E}-17 \mathrm{BAB}$ & 100 & 53 & .3 & .21 & .005 & 18 & 470 \\
\hline $26 S-01 E-29 D D D$ & 210 & 42 & .3 & $<.01$ & .012 & 3.5 & 600 \\
\hline $27 \mathrm{~S}-01 \mathrm{E}-09 \mathrm{BBB}$ & 86 & 96 & .4 & .33 & .008 & 12 & 450 \\
\hline $27 \mathrm{~s}-01 \mathrm{~F}-04 \mathrm{DDD}$ & 410 & 73 & .3 & .055 & .009 & 4.4 & 840 \\
\hline $28 \mathrm{~S}-01 \mathrm{E}-02 \mathrm{BBA}$ & 67 & 66 & .2 & .043 & .009 & 5.5 & 340 \\
\hline $28 \mathrm{~S}-01 \mathrm{E}-02 \mathrm{AAC}$ & 560 & 210 & .3 & .48 & .022 & 4.8 & 1,300 \\
\hline $28 S-01 E-10 A C B$ & 290 & 140 & .3 & .23 & .020 & 10 & 840 \\
\hline $28 \mathrm{~S}-01 \mathrm{E}-27 \mathrm{BCB}$ & 110 & 290 & .6 & .73 & .020 & 11 & 880 \\
\hline $28 \mathrm{~S}-01 \mathrm{E}-35 \mathrm{RAA}$ & 150 & 29 & .2 & .074 & .031 & 6.2 & 410 \\
\hline $27 \mathrm{~s}-01 \mathrm{~W}-10 \mathrm{CDC}$ & 87 & 130 & .4 & .044 & .009 & 4.0 & 490 \\
\hline $28 \mathrm{~S}-01 \mathrm{w}-11 \mathrm{CCD}$ & 62 & 89 & .6 & .061 & .006 & 5.3 & 410 \\
\hline $28 \mathrm{~S}-01 \mathrm{E}-33 \mathrm{DAD}$ & 110 & $53 n$ & .4 & 1.9 & .039 & 10 & 1,250 \\
\hline $29 \mathrm{~S}-01 \mathrm{E}-12 \mathrm{BCD}$ & 140 & 370 & .4 & .17 & .018 & 12 & 1,000 \\
\hline $29 \mathrm{~S}-01 \mathrm{E}-13 \mathrm{DBC}$ & 690 & 56 & .3 & .15 & .010 & 13 & 1,310 \\
\hline $29 \mathrm{~S}-02 \mathrm{E}-31 \mathrm{CCC}$ & 150 & 380 & .4 & .17 & .017 & 12 & 1,020 \\
\hline $29 \mathrm{~S}-02 \mathrm{E}-33 \mathrm{CDC}$ & 1300 & 77 & .3 & .24 & .009 & 9.2 & 2,260 \\
\hline $26 \mathrm{~S}-02 \mathrm{~W}-26 \mathrm{DAD}$ & 230 & 96 & .5 & .013 & .011 & 9.4 & 670 \\
\hline $27 \mathrm{~S}-02 \mathrm{~W}-01 \mathrm{BCB}$ & 110 & 140 & .3 & .050 & .011 & 3.3 & 660 \\
\hline $28 \mathrm{~S}-01 \mathrm{~W}-05 \mathrm{BAA}$ & 62 & 52 & .3 & .027 & .015 & 17 & 420 \\
\hline $28 \mathrm{~S}-01 \mathrm{~W}-16 \mathrm{CCB}$ & 160 & 120 & .3 & .19 & .009 & 2.8 & 640 \\
\hline $28 \mathrm{~S}-01 \mathrm{~W}-23 \mathrm{CRB}$ & 67 & 50 & .3 & .040 & .012 & 15 & 410 \\
\hline $29 \mathrm{~S}-01 \mathrm{E}-06 \mathrm{AAB}$ & 97 & 74 & .3 & .055 & .010 & 14 & 470 \\
\hline $29 \mathrm{~S}-01 \mathrm{E}-34 \mathrm{CCC}$ & 96 & 77 & .3 & .052 & .012 & 15 & 500 \\
\hline $27 \mathrm{~S}-04 \mathrm{~N}-17 \mathrm{BBD}$ & 52 & 85 & .3 & .043 & .007 & 10 & 380 \\
\hline $28 \mathrm{~S}-04 \mathrm{~W}-14 \mathrm{BAB}$ & 55 & 22 & .3 & .038 & .004 & 7.0 & 340 \\
\hline $28 \mathrm{~S}-04 \mathrm{~W}-22 \mathrm{ABA}$ & 64 & 120 & .4 & .052 & .009 & 9.4 & 480 \\
\hline $28 \mathrm{~S}-04 \mathrm{~W}-26 \mathrm{CCC}$ & 57 & 200 & .4 & .085 & .006 & 10 & 610 \\
\hline $28 \mathrm{~S}-04 \mathrm{~W}-34 \mathrm{DAD}$ & 210 & 51 & .3 & .037 & .009 & 3.6 & 650 \\
\hline $29 \mathrm{~S}-03 \mathrm{~W}-06 \mathrm{BAB}$ & 59 & 180 & .4 & .079 & .006 & 10 & 580 \\
\hline $29 \mathrm{~s}-04 \mathrm{~W}-01 \mathrm{DDD}$ & 94 & 27 & .3 & .051 & .005 & 8.9 & 370 \\
\hline $29 \mathrm{~S}-03 \mathrm{~W}-07 \mathrm{DDA}$ & 330 & 82 & .3 & .052 & .006 & $<1.0$ & 820 \\
\hline $29 \mathrm{~S}-03 \mathrm{~W}-03 \mathrm{BAA}$ & 110 & 33 & .3 & .046 & .008 & $<1.0$ & 420 \\
\hline $29 \mathrm{~S}-03 \mathrm{~W}-23 \mathrm{AAA}$ & 63 & 170 & .4 & .071 & .009 & 9.9 & 570 \\
\hline $29 \mathrm{~S}-02 \mathrm{~W}-19 \mathrm{AAB}$ & 110 & 35 & .4 & .054 & .006 & 9.2 & 440 \\
\hline $29 \mathrm{~S}-02 \mathrm{~W}-26 \mathrm{ccc}$ & 68 & 170 & .4 & .095 & .008 & 9.4 & 570 \\
\hline $29 \mathrm{~S}-01 \mathrm{~W}-35 \mathrm{CDC}$ & 99 & 40 & .3 & .056 & .006 & 9.6 & 430 \\
\hline $25 \mathrm{~S}-02 \mathrm{E}-13 \mathrm{ACA}$ & 400 & 50 & .3 & .10 & .008 & 6.5 & 850 \\
\hline $25 S-02 E-25 A D D$ & 1100 & 270 & .3 & .97 & .027 & 8.0 & 2,210 \\
\hline $26 \mathrm{~S}-02 \mathrm{E}-01 \mathrm{DDD}$ & 620 & 660 & .3 & 2.4 & .020 & 10 & 2,170 \\
\hline $26 \mathrm{~S}-02 \mathrm{E}-36 \mathrm{DAD}$ & 39 & 15 & .2 & $<.01$ & .005 & 10 & 240 \\
\hline $27 \mathrm{~S}-02 \mathrm{E}-25 \mathrm{DAA}$ & 730 & 110 & .5 & .24 & .013 & 10 & 1,420 \\
\hline $27 \mathrm{~S}-02 \mathrm{E}-36 \mathrm{ADA}$ & 780 & 79 & .5 & .22 & .011 & 10 & 1,420 \\
\hline
\end{tabular}


Table 11. Streamflow and water-quality data collected during low-flow reconnaissance in Sedgwick County, March 11-14,1985--Continued

\begin{tabular}{|c|c|c|c|c|c|c|}
\hline $\begin{array}{l}\text { Local identifier } \\
\text { (township-range- } \\
\text { section, plate } 1 \text { ) }\end{array}$ & $\begin{array}{l}\text { Nitrogen } \\
\text { ammonia, } \\
\text { dissolved } \\
\text { (mill i- } \\
\text { grams per } \\
\text { 1iter as } \\
\text { N) }\end{array}$ & $\begin{array}{l}\text { Nitrogen } \\
\mathrm{NO}_{2}+\mathrm{NO}_{3}, \\
\text { dissolved } \\
\text { (mill i- } \\
\text { grams per } \\
1 \text { iter } \\
\text { as } \mathrm{N} \text { ) }\end{array}$ & $\begin{array}{l}\text { Phos- } \\
\text { phorus, } \\
\text { dissolved } \\
\text { (milli- } \\
\text { grams per } \\
1 \text { iter } \\
\text { as P) }\end{array}$ & $\begin{array}{l}\text { Iron, } \\
\text { dissolved } \\
\text { (micro- } \\
\text { grams per } \\
\text { 1iter as } \\
\quad \text { Fe) }\end{array}$ & $\begin{array}{l}\text { Manga- } \\
\text { nese, } \\
\text { dissol ved } \\
\text { (micro- } \\
\text { grams per } \\
1 \text { iter as } \\
\text { Mn) }\end{array}$ & $\begin{array}{l}\text { Carbon, } \\
\text { organic, } \\
\text { total } \\
\text { (milli- } \\
\text { grams per } \\
1 \text { iter } \\
\text { as C) }\end{array}$ \\
\hline $25 S-03 w-09 B B C$ & 0.20 & 1.90 & 0.37 & 30 & 20 & 6.1 \\
\hline $25 \mathrm{~S}-02 \mathrm{~W}-26 \mathrm{CCB}$ & .07 & 1.70 & .31 & 60 & 20 & 4.7 \\
\hline $26 \mathrm{~S}-01 \mathrm{~W}-14 \mathrm{DDB}$ & .05 & 1.70 & .30 & 40 & 10 & 5.3 \\
\hline $27 \mathrm{~S}-01 \mathrm{~W}-12 \mathrm{BAD}$ & .10 & 1.70 & .26 & 40 & 20 & 6.4 \\
\hline $25 \mathrm{~S}-01 \mathrm{~W}-15 \mathrm{BBB}$ & .62 & 2.20 & .55 & 18 & 48 & 13 \\
\hline $25 \mathrm{~S}-01 \mathrm{~W}-23 \mathrm{ACD}$ & .03 & 2.00 & .16 & 18 & 64 & 5.8 \\
\hline $25 S-01 W-36 C \cdot R A$ & .37 & 2.10 & .46 & 83 & 47 & 14 \\
\hline $26 \mathrm{~S}-01 \mathrm{E}-29 \mathrm{CCC}$ & .29 & 2.70 & .58 & 92 & 38 & 12 \\
\hline $28 S-01 F-05 A B B$ & .19 & 1.70 & .30 & 18 & 20 & 5.6 \\
\hline $26 \mathrm{~S}-01 \mathrm{~F}-16 \mathrm{BAB}$ & .39 & 1.30 & .79 & 15 & 140 & 7.4 \\
\hline $26 \mathrm{~S}-01 \mathrm{~F}-17 \mathrm{BAB}$ & .04 & $<.10$ & .01 & 11 & 210 & 1.0 \\
\hline $26 S-01 E-29 D D D$ & .04 & .75 & .04 & 20 & 28 & 7.4 \\
\hline $27 \mathrm{~S}-01 \mathrm{E}-09 \mathrm{RBR}$ & .04 & .52 & 1.90 & 40 & 42 & 7.2 \\
\hline $27 \mathrm{~S}-01 \mathrm{E}-04 \mathrm{DDD}$ & .05 & .31 & .06 & 220 & 110 & 7.6 \\
\hline $28 \mathrm{~S}-01 \mathrm{E}-02 \mathrm{BAA}$ & .02 & .13 & .08 & 19 & 11 & 6.6 \\
\hline $28 \mathrm{~S}-01 \mathrm{E}-02 \mathrm{AAC}$ & .10 & $<.10$ & .04 & 15 & 140 & 5.8 \\
\hline $28 \mathrm{~S}-01 \mathrm{E}-10 \mathrm{ACB}$ & .17 & 1.30 & .12 & 15 & 65 & 5.0 \\
\hline $28 S-01 E-27 B C B$ & .06 & $<.10$ & .03 & 14 & 380 & 3.7 \\
\hline $28 \mathrm{~S}-01 \mathrm{~F}-35 \mathrm{BAA}$ & .08 & .51 & .06 & 10 & 100 & 8.3 \\
\hline $27 \mathrm{~S}-01 \mathrm{~W}-10 \mathrm{CNC}$ & .01 & 1.00 & .01 & 23 & 2 & 2.8 \\
\hline $28 s-01 \mathrm{~W}-11 \mathrm{CCD}$ & .01 & $<.10$ & .01 & 31 & 7 & 4.8 \\
\hline $28 \mathrm{~S}-01 \mathrm{E}-33 \mathrm{DAD}$ & .08 & .22 & .03 & 30 & 560 & 3.0 \\
\hline $29 S-01 E-12 B C D$ & 1.70 & 1.70 & .92 & 22 & 29 & 6.0 \\
\hline $29 S-01 F-13 D B C$ & .13 & .62 & .07 & 8 & 340 & 4.2 \\
\hline $29 \mathrm{~S}-02 \mathrm{~F}-31 \mathrm{CCC}$ & 1.50 & 2.00 & .95 & 14 & 34 & 7.8 \\
\hline $29 S-02 E-33 C D C$ & .28 & .27 & .03 & 40 & 270 & 3.3 \\
\hline $26 S-02 W-26 D A D$ & .74 & 1.20 & .79 & 25 & 43 & 5.7 \\
\hline $27 \mathrm{~S}-02 \mathrm{~W}-01 \mathrm{BCB}$ & .03 & $<.10$ & .66 & 11 & 46 & 11 \\
\hline $28 \mathrm{~S}-01 \mathrm{~W}-05 \mathrm{BAA}$ & .34 & 1.20 & .27 & 34 & 100 & 5.7 \\
\hline $28 S-01 W-16 C C B$ & .03 & $<.10$ & .06 & 10 & 44 & 6.8 \\
\hline $28 S-01 W-23 C B R$ & .23 & 1.10 & .24 & 29 & 22 & 6.3 \\
\hline $29 S-01 F-06 A A B$ & .13 & 1.00 & .17 & 17 & 75 & 5.5 \\
\hline $29 S-01 E-34 C C C$ & 1.20 & 1.50 & .81 & 18 & 83 & 7.0 \\
\hline $27 \mathrm{~S}-04 \mathrm{~W}-17 \mathrm{BBD}$ & .04 & 3.70 & .04 & 12 & 28 & 3.3 \\
\hline $28 \mathrm{~S}-04 \mathrm{~W}-14 \mathrm{BAR}$ & .02 & 3.40 & .03 & 18 & 24 & 4.0 \\
\hline $28 \mathrm{~S}-04 \mathrm{~W}-22 \mathrm{ABA}$ & .06 & $1.1 n$ & .05 & 12 & 35 & 3.6 \\
\hline $28 \mathrm{~S}-04 \mathrm{~W}-26 \mathrm{CCC}$ & .02 & 1.70 & .05 & 10 & 2 & 2.9 \\
\hline $28 \mathrm{~S}-04 \mathrm{~W}-34 \mathrm{DAN}$ & .02 & .71 & .01 & 8 & 25 & 5.6 \\
\hline $29 S-03 W-06 B A B$ & .02 & 1.50 & .05 & 8 & 9 & 3.1 \\
\hline $29 \mathrm{~S}-04 \mathrm{~W}-01 \mathrm{DDD}$ & .02 & 2.20 & .02 & 21 & 40 & 3.7 \\
\hline $29 s-03 w-07 D D A$ & .04 & .53 & .02 & 6 & 55 & 4.2 \\
\hline $29 S-03 W-03 B A A$ & .06 & 1.90 & .04 & 5 & 78 & 4.8 \\
\hline $29 \mathrm{~S}-03 \mathrm{~W}-23 \mathrm{AAA}$ & .03 & 1.50 & .06 & 29 & 4 & 3.1 \\
\hline $29 S-02 W-19 A A B$ & .03 & 3.60 & .17 & 15 & 49 & 5.8 \\
\hline $29 \mathrm{~s}-02 \mathrm{w}-26 \mathrm{CCC}$ & .03 & 1.30 & .06 & 10 & 3 & 3.7 \\
\hline $29 \mathrm{~s}-01 \mathrm{w}-35 \mathrm{CDC}$ & .03 & 1.40 & .06 & 5 & 59 & 5.2 \\
\hline $25 \mathrm{~S}-02 \mathrm{~F}-13 \mathrm{ACA}$ & .08 & 1.40 & .04 & 9 & 120 & 5.4 \\
\hline $25 \mathrm{~S}-02 \mathrm{E}-25 \mathrm{ADN}$ & .19 & .59 & .01 & 40 & 430 & 3.2 \\
\hline $26 \mathrm{~S}-02 \mathrm{~F}-01 \mathrm{DDD}$ & .15 & .49 & $<.01$ & 40 & 540 & 2.8 \\
\hline $26 \mathrm{~S}-02 \mathrm{~F}-36 \mathrm{DAD}$ & .02 & .52 & .04 & 63 & 22 & 7.9 \\
\hline $27 \mathrm{~S}-02 \mathrm{E}-25 \mathrm{DAA}$ & .25 & .55 & .25 & 5 & 160 & 4.3 \\
\hline $27 \mathrm{~S}-02 \mathrm{E}-36 \mathrm{ADA}$ & .13 & $<.10$ & $<.01$ & 20 & 190 & 3.4 \\
\hline
\end{tabular}




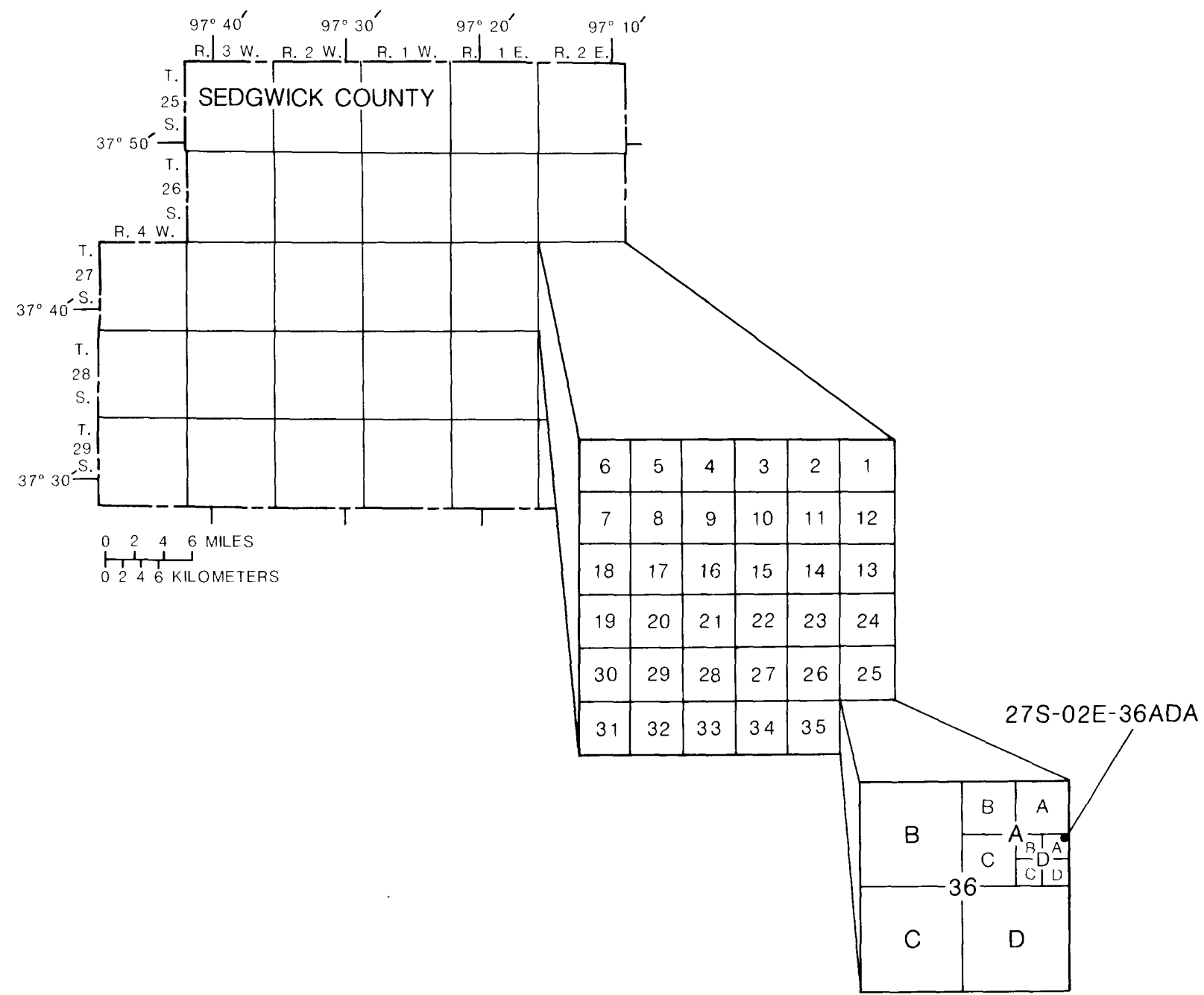

Figure 14. Method used to describe location of sampling sites.

Water in the Arkansas River was a sodium chloride type throughout its reach in Sedgwick County as a result of saline groundwater discharge from Permian shale upstream. Concentrations of dissolved solids decreased downstream from $1,760 \mathrm{mg} / \mathrm{L}$ near Mount Hope to $1,660 \mathrm{mg} / \mathrm{L} 4$ miles east of Maize, which indicates that the stream water was being diluted by ground-water discharge with smaller concentrations of dissolved solids. Streamflow measurements discussed in the "Streamflow Characteristics" section also indicate the stream was gaining through this reach. Concentrations of dissolved solids remained nearly constant in the reach from 4 miles east of Maize to $21 \mathrm{st}$ Street in Wichita. Streamflow measurements indicate that the stream was losing through this reach.

Downstream from the confluence with the Little Arkansas River, concentrations of dissolved solids in the Arkansas River at Pawnee Street in Wichita decreased to $1,060 \mathrm{mg} / \mathrm{L}$ due to dilution from the Little Arkansas River, which increased the flow in the Arkansas River by about 70 percent. At Derby, concentrations of dissolved solids had decreased slightly to 1,000 $\mathrm{mg} / \mathrm{L}$ as flow increased by 95 cubic feet per second. Effluent from the Wichita sewagetreatment plant, which in 1982 emitted an average flow of about 60 cubic feet per second (data from Wichita Water Pollution Control Division), probably was diluting the stream 
water. The concentration of dissolved chloride was $420 \mathrm{mg} / \mathrm{L}$ at Pawnee Street, $370 \mathrm{mg} / \mathrm{L}$ at Derby, and only averaged $180 \mathrm{mg} / \mathrm{L}$ in Wichita sewage-treatment plant effluent during 1982 (data from Wichita Water Pollution Control Division). Although treated sewage effluent slightly decreased concentrations of dissolved solids and major ions, the concentration of ammonia as nitrogen had increased at Derby to a concentration $(1.70 \mathrm{mg} / \mathrm{L})$ that exceeded criterion for sources of public-water supplies $(0.50 \mathrm{mg} / \mathrm{L})$. The concentration of dissolved solids at Mulvane was almost the same as that at Derby $(1,020$ $\mathrm{mg} / \mathrm{L}$ ), and the concentration of ammonia as nitrogen $(1.50 \mathrm{mg} / \mathrm{L})$ still exceeded the criterion for sources of public-water supplies. The constancy of dissolved-solids concentrations in this reach helps substantiate that the stream was losing through this reach, as indicated by streamflow measurements.

The Little Arkansas River contained water that was a calcium bicarbonate type and had a dissolved-solids concentration of $350 \mathrm{mg} / \mathrm{L}$ near Sedgwick where it enters the county. The calcium and bicarbonate are derived from calcareous shale and limestone of the Wellington Formation. The concentration of ammonia as nitrogen $(0.62 \mathrm{mg} / \mathrm{L})$ exceeded criterion for sources of public-water supplies and might indicate contamination by sewage-treatment plant effluent from Sedgwick. At Valley Center, the chemical type of water and the dissolvedsolids concentration $(340 \mathrm{mg} / \mathrm{L})$ were virtually the same as observed at Sedgwick, but the ammonia-as-nitrogen concentration did not exceed criterion for sources of public-water supplies. The sampling site at Valley Center was upstream of the sewage-treatment plant effluent. Farther downstream at 37 th Street in Wichita, water in the Little Arkansas River was a mixed calcium sodium bicarbonate chloride type, with $400 \mathrm{mg} / \mathrm{L}$ dissolved solids. Sodium and chloride accounted for most of the increase in dissolved-solids concentration. The Little Arkansas River probably is gaining some sodium chloride type ground water in this area.

Cowskin Creek, a tributary to the Arkansas River, undergoes several changes in water quality as it flows through the county. Cowskin Creek near Maize had a mixed sodium sulfate bicarbonate type water, with a dissolvedsolids concentration of $670 \mathrm{mg} / \mathrm{L}$. The ammonia- as-nitrogen concentration $(0.74 \mathrm{mg} / \mathrm{L})$ exceeded water-quality criteria for sources of public supplies and might indicate contamination by sewage-treatment plant effluent from Colwich. The water in Dry Creek near Maize, a tributary to Cowskin Creek, had a mixed sodium calcium bicarbonate chloride type water, with a dissolved-solids concentration of $660 \mathrm{mg} / \mathrm{L}$. The water may be from the Wellington Formation, which has limestone (source of calcium and bicarbonate) and shale (source of sodium and chloride). Dry Creek probably receives some flow from sewage lagoons at Goddard, which may be the source of some of the mixed-ion type water. The concentration of ammonia as nitrogen was small, but the concentration of phosphorus was relatively large $(0.66 \mathrm{mg} / \mathrm{L})$ and in the same range as other stream sites in the county that are affected by sewage effluent.

Farther downstream, in Cowskin Creek at Pawnee Street in Wichita, the water is a calcium sodium bicarbonate type, with a dissolved-solids concentration of $420 \mathrm{mg} / \mathrm{L}$. Small tributaries that drain areas underlain by the Wellington Formation and terrace deposits to the west probably are diluting the water from upstream reaches of Cowskin Creek with a calcium bicarbonate type water that has relatively small concentrations of dissolved solids. Dry Creek at Tyler Street in Wichita, no relation to Dry Creek near Maize, flows from the west into Cowskin Creek. Dry Creek at Tyler Street has a mixedion type water, with a dissolved-solids concentration of $640 \mathrm{mg} / \mathrm{L}$. This mixed-ion type water may be from the Wellington Formation, which has gypsum and anhydrite deposits (sources of calcium and sulfate) in addition to limestone and shale.

Downstream from the confluence of Cowskin Creek and Dry Creek, the water in Cowskin Creek at 47th Street in Wichita was a calcium sodium bicarbonate type, with $410 \mathrm{mg} / \mathrm{L}$ of dissolved solids. At Haysville, the water in Cowskin Creek was a sodium bicarbonate chloride sulfate type, with a dissolved-solids concentration of $470 \mathrm{mg} / \mathrm{L}$. Upstream from Haysville, Cowskin Creek mixes with water in the Wichita-Valley Center floodway, which may cause the change in water type. At the Sumner County line, water in Cowskin Creek was a mixed-ion type, with a dissolved-solids concentration of $500 \mathrm{mg} / \mathrm{L}$. The concentration of 
ammonia as nitrogen $(1.20 \mathrm{mg} / \mathrm{L})$ exceeds criterion for sources of public-water supplies and might be due to sewage-treatment plant effluent at Haysville.

Big Slough Creek will be discussed in conjunction with the Wichita-Valley Center floodway because the creek is diverted into the floodway near Maple Street in Wichita. The downstream reach of Big Slough Creek that flows into the Arkansas River receives only local drainage south of 31st Street in Wichita. When samples were collected, the farthest upstream site where flow was detected was at 13 th Street in Wichita. At this site the water was a sodium chloride bicarbonate type, with a dissolved-solids concentration of $490 \mathrm{mg} / \mathrm{L}$. The sodium and chloride probably result from saline water from the Arkansas River that has moved into alluvial deposits in this area. In the Wichita-Valley Center floodway at MacArthur Road, the water was a sodium bicarbonate chloride type, with a dissolved-solids concentration of $410 \mathrm{mg} / \mathrm{L}$.

Water quality in the floodway near Haysville was much different than at upstream sites. The water was a sodium chloride type, with a dissolved-solids concentration of 1,250 $\mathrm{mg} / \mathrm{L}$. The sodium:chloride ratio computed by dividing the concentration of sodium by the concentration of chloride was about 0.53 . A sodium:chloride ratio of less than 0.60 may indicate contamination by oilfield brine (Whittemore, 1982). The Gladys oilfield is located upstream of this site. The downstream reach of Big Slough Creek was sampled at Hydraulic Street in Wichita where the water was a sodium chloride type, with a dissolved-solids concentration of $880 \mathrm{mg} / \mathrm{L}$. The sodium:chloride ratio at this site was 0.62 , indicating the source probably is dissolved salt from Permian rocks provided by ground water in the alluvium, which has infiltrated from the Arkansas River. However, there is an oilfield upstream of this site, and some of the sodium and chloride may be from oilfield brine.

Water-quality samples also were collected from Chisholm Creek and its tributaries. Water in West Fork Chisholm Creek near Park City was a mixed-ion type, with a dissolved-solids concentration of $680 \mathrm{mg} / \mathrm{L}$. The Park City sewage-treatment plant discharges effluent upstream of this site. The concentration of ammonia as nitrogen $(0.39 \mathrm{mg} / \mathrm{L})$ was relatively large but did not exceed criterion for sources of public-water supplies. The concentration of phosphorus $(0.79 \mathrm{mg} / \mathrm{L})$ was in the same range as in other streams in the county that receive sewage-treatment plant effluent. Flow in a tributary to West Fork Chisholm Creek near Park City was provided by effluent from a Derby Oil Company facility upstream. The water was a calcium bicarbonate type, with $470 \mathrm{mg} / \mathrm{L}$ dissolved solids.

Middle Fork Chisholm Creek was sampled at Broadway Street in Wichita where the water was a calcium bicarbonate sulfate type, with 600 $\mathrm{mg} / \mathrm{L}$ dissolved solids. The source of these constituents probably is natural dissolution of minerals (gypsum, anhydrite, and limestone) in the Wellington Formation.

Chisholm Creek at 21st Street in Wichita had a sodium bicarbonate chloride type water, with $450 \mathrm{mg} / \mathrm{L}$ dissolved solids. The $\mathrm{pH}$ (9.1) was very high, and the concentration of phosphorus $(1.9 \mathrm{mg} / \mathrm{L})$ was also very large, indicating possible contamination from an unknown source. Chisholm Creek receives only local drainage at this site because West Fork and Middle Fork Chisholm Creeks are diverted into the WichitaValley Center floodway.

East Fork Chisholm Creek was sampled at 21st Street in Wichita, where the water was a calcium magnesium sulfate type, with $840 \mathrm{mg} / \mathrm{L}$ of dissolved solids. The concentration of dissolved iron $(220 \mu \mathrm{g} / \mathrm{L})$ was the largest observed at any stream site in the county. The calcium and sulfate probably result from the dissolution of gypsum in the Wellington Formation.

Dry Creek at Pawnee Street in Wichita, a tributary to Chisholm Creek, had a mixed-ion type water, with a dissolved-solids concentration of $340 \mathrm{mg} / \mathrm{L}$. Gypsum Creek at George Washington Boulevard in Wichita, also a tributary to Chisholm Creek, had a calcium sulfate type water, with $1,300 \mathrm{mg} / \mathrm{L}$ dissolved solids. As the name of Gypsum Creek suggests, flow in the creek probably results from a spring developed in an easily erodible gypsum deposit. Chisholm Creek upstream from its confluence with the Arkansas River had a mixed-ion type water, with calcium and sulfate as the principal 
dissolved constituents. The concentration of dissolved solids at this site was $840 \mathrm{mg} / \mathrm{L}$. Water quality at this site represents the combined characteristics of Chisholm Creek at 21st Street, East Fork Chisholm Creek at 21st Street, and Gypsum Creek at George Washington Boulevard.

Small streams that originate in the area underlain by the Wellington Formation and flow west to the Little Arkansas River (Jester Creek near Valley Center, a small tributary that flows through the southeast corner at McConnell Air Force Base and enters the Arkansas River 1 mile northwest of Derby, Spring Creek at Kansas Highway 15 south of Derby, and Dog Creek near Mulvane) were also sampled. Jester Creek near Valley Center had a calcium bicarbonate type water, with $490 \mathrm{mg} / \mathrm{L}$ dissolved solids. The Arkansas River tributary 1 mile northwest of Derby had a calcium sulfate bicarbonate type water, with $410 \mathrm{mg} / \mathrm{L}$ dissolved solids. Spring Creek at Kansas Highway 15 had a calcium sulfate type water, with $1,340 \mathrm{mg} / \mathrm{L}$ dissolved solids. Dog Creek near Mulvane had a calcium sulfate type water, with $2,260 \mathrm{mg} / \mathrm{L}$ dissolved solids.

Small streams that originate in the area underlain by the Wellington Formation in eastern Sedgwick County and flow to the east as tributaries to the Walnut River include Wildcat, Prairie, Whitewater, Dry, Fourmile, and Spring Branch Creeks. Wildcat Creek had a calcium sulfate type water, with $850 \mathrm{mg} / \mathrm{L}$ dissolved solids. Prairie Creek had a calcium sulfate type water, with $2,210 \mathrm{mg} / \mathrm{L}$ dissolved solids. A sodium:chloride ratio of 0.59 indicates possible contamination of Prairie Creek by oilfield brine. Whitewater Creek had a calcium chloride type water, with $2,170 \mathrm{mg} / \mathrm{L}$ dissolved solids. A sodium:chloride ratio of 0.38 indicates that Whitewater Creek is contaminated by oilfield brine. Dry Creek at the Butler County line had calcium bicarbonate type water, with only 240 $\mathrm{mg} / \mathrm{L}$ dissolved solids. Fourmile Creek had a calcium sulfate type water, with $1,420 \mathrm{mg} / \mathrm{L}$ dissolved solids. The sodium:chloride ratio of 0.58 indicates possible contamination of Fourmile Creek by oilfield brine. Spring Branch Creek at the Butler County line had a calcium sulfate type water, with $1,420 \mathrm{mg} / \mathrm{L}$ dissolved solids.
Water was not being released from Cheney Reservoir during the time that samples were collected from the Ninnescah River system but had been released for 21 consecutive days prior to sample collection. Consequently, flow in the North Fork Ninnescah River was provided primarily by seepage from water in the alluvium that had been stored during the period of release from Cheney Reservoir.

The North Fork Ninnescah River at Kansas Highway 251 (downstream of Cheney Reservoir) had a sodium calcium bicarbonate chloride type water, with $380 \mathrm{mg} / \mathrm{L}$ dissolved solids. Downstream near Cheney the water type was the same, and the dissolved-solids concentration had increased to $480 \mathrm{mg} / \mathrm{L}$. Some of the flow at this site was from sewagetreatment plant effluent at Cheney, but concentrations of ammonia as nitrogen (0.06 $\mathrm{mg} / \mathrm{L})$ and phosphorus $(0.05 \mathrm{mg} / \mathrm{L})$ were small. In the South Fork Ninnescah River near Cheney, the water was a sodium chloride type, with 610 $\mathrm{mg} / \mathrm{L}$ dissolved solids. The sodium chloride water is discharged to the stream from Permian shale west of Sedgwick County. Downstream from the confluence of the North and South Forks of the Ninnescah River, in the Ninnescah River 6 miles southeast of Cheney, the water was a sodium chloride type, with $580 \mathrm{mg} / \mathrm{L}$ dissolved solids. The South Fork Ninnescah River provided about 76 percent of the flow at this site.

In the Ninnescah River at Kansas Highway 42 , the water was a sodium chloride bicarbonate type, with a dissolved-solids concentration of $570 \mathrm{mg} / \mathrm{L}$. At Clearwater, the water was a sodium chloride bicarbonate type, with $570 \mathrm{mg} / \mathrm{L}$ dissolved solids. Streamflow measurements indicate that the flow at Kansas Highway 42 and at Clearwater was about the same, and the fact that water-quality characteristics at the two sites were essentially the same indicates that the stream was not gaining in this reach, possibly because of groundwater withdrawals for industrial use west of Clearwater.

Small streams draining areas north of the Ninnescah River that were sampled include Spring Creek near Cheney, Clearwater Creek 3 miles south of Lake Afton, Spring Creek 4 miles 
west of Clearwater, and Spring Creek at the Sumner County line. Spring Creek near Cheney had a calcium bicarbonate type water, with 340 $\mathrm{mg} / \mathrm{L}$ dissolved solids. This stream drains areas underlain by lower Pleistocene deposits (preIllinoian age) and the Ninnescah Shale. Clearwater Creek had a calcium bicarbonate type water, with $420 \mathrm{mg} / \mathrm{L}$ dissolved solids. Clearwater Creek drains areas underlain by lower Pleistocene deposits, the Ninnescah Shale, and the Wellington Formation. Spring Creek, 4 miles west of Clearwater drains areas underlain by lower Pleistocene deposits and the Wellington Formation. The water in this stream was a calcium magnesium bicarbonate type, with 440 $\mathrm{mg} / \mathrm{L}$ dissolved solids. Spring Creek at the Sumner County line drains an area underlain by terrace deposits of Illinoian age. This stream had a calcium magnesium sodium bicarbonate type water, with $430 \mathrm{mg} / \mathrm{L}$ dissolved solids.
Small streams draining areas south of the Ninnescah River that were sampled include Mud Creek, Sand Creek, and an unnamed tributary 3 miles northwest of Viola. These streams drain areas underlain by the Ninnescah Shale. Mud Creek had a mixed-ion type water, with 650 $\mathrm{mg} / \mathrm{L}$ dissolved solids. Sand Creek originates in an area underlain by a buried valley containing terrace deposits of Illinoian age. Sand Creek had a calcium magnesium sodium bicarbonate type water, with $370 \mathrm{mg} / \mathrm{L}$ dissolved solids. The unnamed tributary 3 miles northwest of Viola had a mixed-ion type water, with $820 \mathrm{mg} / \mathrm{L}$ dissolved solids.

\section{Impoundments}

\section{Storage Requirements}

The storage requirement of an

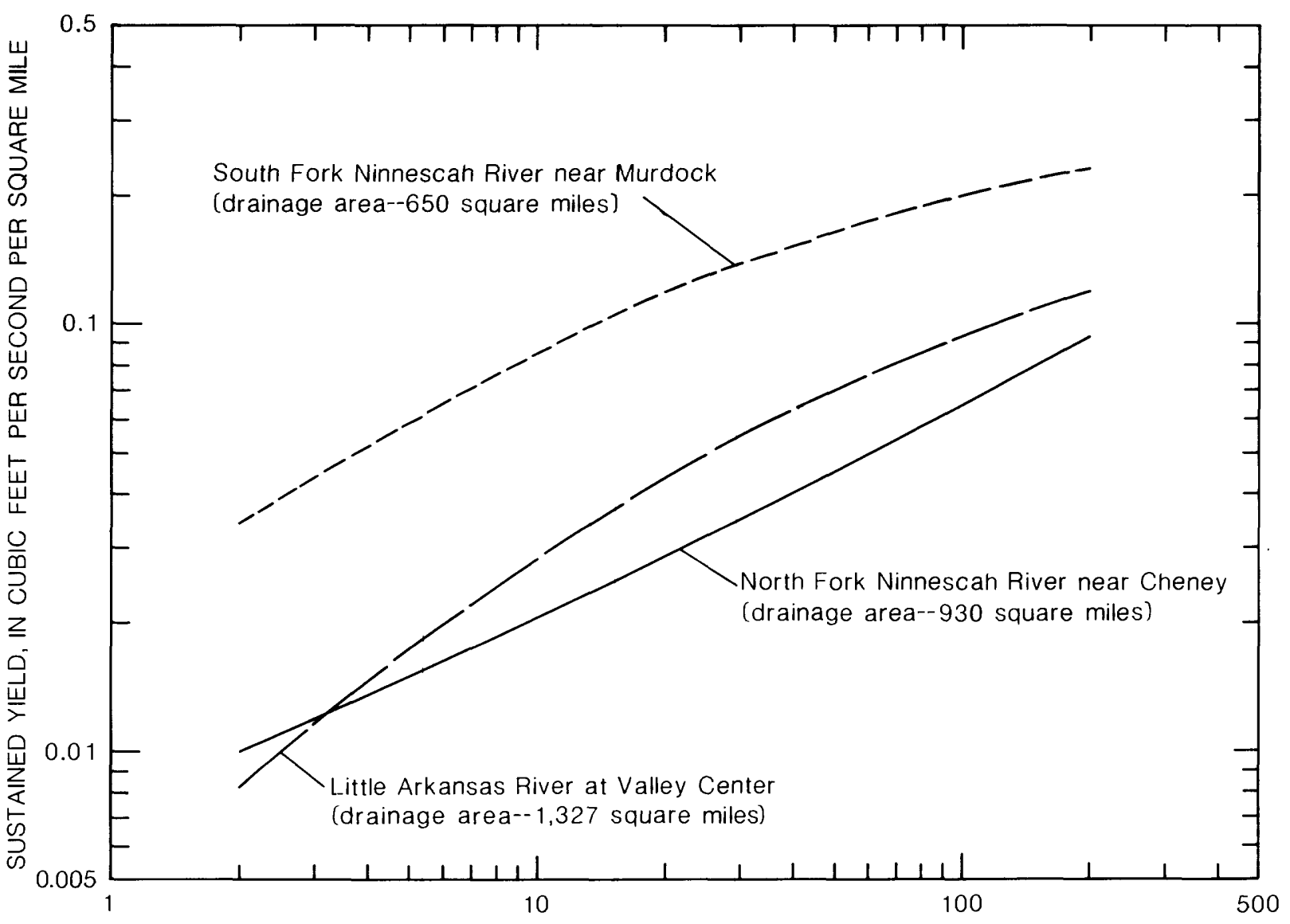

STORAGE REQUIREMENT, IN ACRE-FEET PER SQUARE MILE

Figure 15. Storage-yield curves for Little Arkansas River at Valley Center, North Fork Ninnescah River near Cheney, and South Fork Ninnescah River near Murdock, representing a 2-percent chance of deficiency (modified from Furness, 1962). 
impoundment is defined as the volume of water that must be stored in order to provide a sustained yield from the impoundment with a selected chance of deficiency. The sustained yield is equivalent to the volume of water withdrawn or released for selected uses in addition to natural losses due to evapotranspiration, seepage, and loss of storage in the impoundment due to sedimentation. Previous investigations have presented methods used to develop storage-yield curves for gaged and ungaged basins in Kansas with drainage areas greater than 100 square miles (Furness, 1962) and for basins with drainage areas less than 300 square miles (Carswell, 1982).

Storage-yield curves presented by Furness (1962) were developed from continuous streamflow records that were 6 years or more in length and were extended by correlation with long-term records to a base period of 37 years (1920-56). It is beyond the scope of this report to update the analysis by Furness. A detailed storage-yield investigation should be conducted using a data base that includes data collected since the Furness study (since 1956) for any site at which the construction of a major impoundment is being considered. Storage-yield curves developed by Furness (1962) for the Little Arkansas River at Valley Center, the North Fork Ninnescah River near Cheney (a discontinued station), and the South Fork Ninnescah River near Murdock with a 2-percent chance of deficiency are shown in figure 15 for comparison purposes. In general, less storage would be required for an impoundment on the South Fork Ninnescah River to provide a selected sustained yield than would be required for impoundments on either the Little Arkansas River or the North Fork Ninnescah River.

In a more recent investigation, Carswell (1982) used streamflow data for all streamflowgaging stations in Kansas that had drainage areas of less than 300 square miles and that had more than 10 years of continuous streamflow record to develop regional storage-yield curves for estimating storage requirements to sustain yields from impoundments on small ungaged streams. Although no data from Sedgwick County were used to develop the regional curves, the curves and procedure developed by Carswell (1982) can be applied in the area and are presented in the following discussion.
The regional storage-yield curves for a 2percent chance of deficiency developed by Carswell (1982) are shown in figure 16. This three-parameter plot relates sustained yield (in cubic feet per second per square mile), mean annual runoff (in inches), and storage (in acrefeet per square mile). For ungaged basins, mean annual runoff can be determined from figure $\mathbf{1 7}$ (Carswell, 1982) by interpolating to the centroid of the basin. Mean annual runoff then is used in figure 16 to determine the sustained yield that would result from storage of $30,100,250,500$, or 1,000 acre-feet per square mile with a 2 -percent chance of deficiency.

Storage-yield curves and procedures presented in this section should only be used for developing estimates of impoundment yield. Detailed site studies should be conducted before the construction of an impoundment. Estimates of water lost to seepage, evapotranspiration, and of storage loss due to sedimentation should be included in the site study. Continuous streamflow records should be collected at sites for major impoundments if data are not available.

\section{Water-Quality Characteristics}

\section{$\underline{\text { Results of water-quality reconnaissance }}$}

Water-quality samples and measurements of physical properties were collected from 14 impoundments in Sedgwick County during October 21-24,1985. These data are presented in table 12. Pie diagrams indicating the concentration of dissolved solids and the proportions of major dissolved ions are shown on plate 1. The impoundments generally were small; Lake Afton, with a surface area of approximately 320 acres, was by far the largest impoundment sampled. The impoundments were used for recreational purposes (fishing, swimming, waterfowl hunting) or for stock watering. The impoundments were selected to provide areal coverage of the county and to represent the varying surface geology. Their locations are identified by an abbreviated landline description, which indicates the township, range, and section in which they are located (see fig. 14). Approximately 2 weeks prior to sampling, a large storm produced significant rainfall and considerable runoff in the county, and the impoundments were relatively full. 


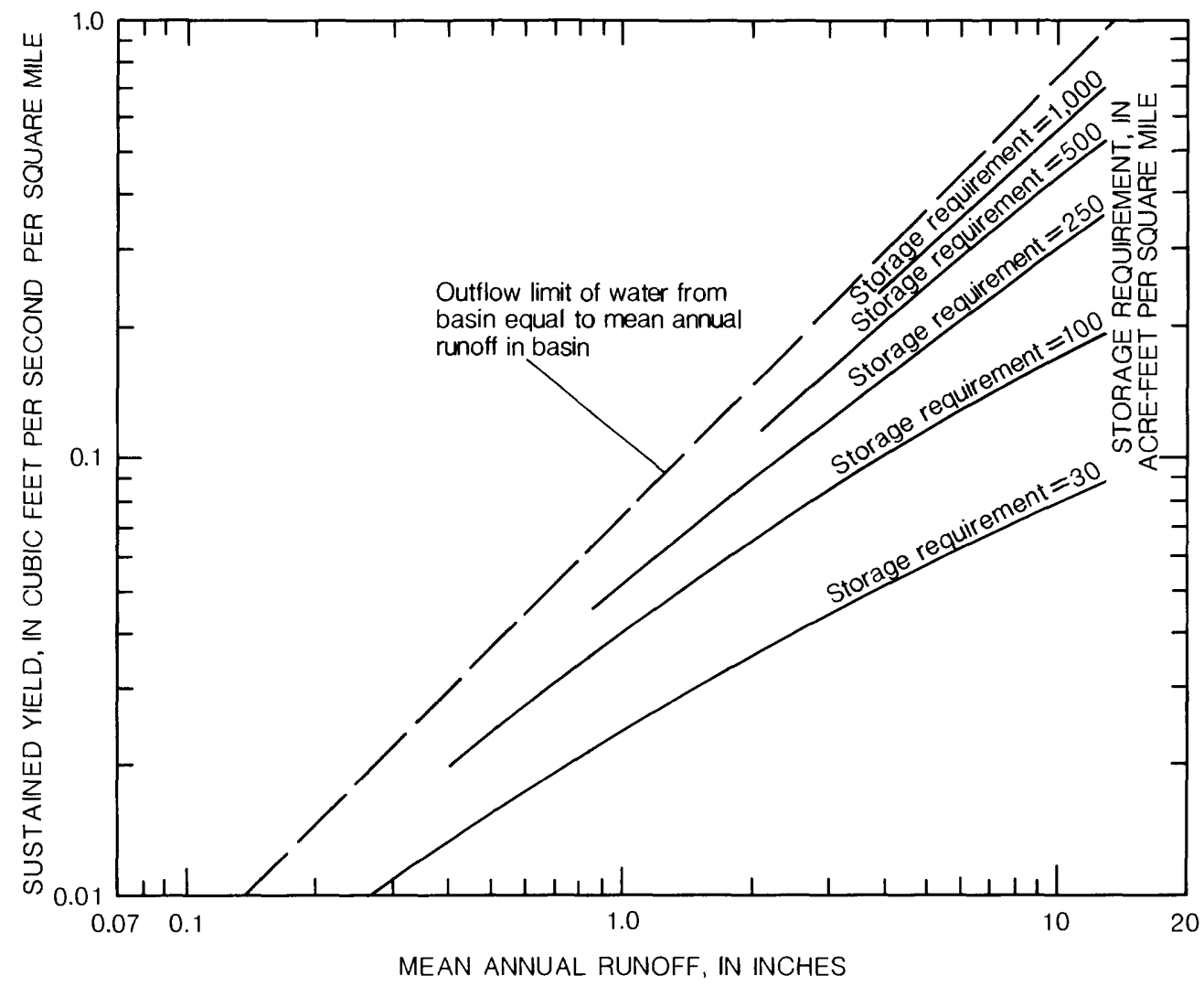

Figure 16. Regional storage-yield curves for unregulated streams with drainage areas less than 300 square miles, representing a 2-percent change of deficiency (modified from Carswell, 1982).

Six lakes were sampled in parts of the county where the Wellington Formation occurs at or near the surface $(25 \mathrm{~S}-02 \mathrm{E}-4 \mathrm{AC}, 25 \mathrm{~S}-01 \mathrm{E}$ 27CB, 26S-02E-10AD, 27S-02E-11BD, 28S-02E24AC, and 29S-02W-15AC). All of these lakes were relatively shallow, with maximum depths ranging from 5.0 feet $(26 \mathrm{~S}-02 \mathrm{E}-10 \mathrm{AD})$ to 10.5 feet (25S-01E-27CB and 28S-02E-24AC). The lakes were relatively turbid, with transparencies (as depth below surface at which a secchi disk could no longer be seen) generally 11.0 inches or less. Lake 28S-02E-24AC had a transparency of 21.5 inches. This lake is supplemented with ground water from a well, which is probably the reason for its relative clarity. Concentrations of dissolved solids in the four lakes where calcium and bicarbonate were the principal dissolved ions ranged from $41 \mathrm{mg} / \mathrm{L}(25 \mathrm{~S}-01 \mathrm{E}-27 \mathrm{CB})$ and $61 \mathrm{mg} / \mathrm{L}(27 \mathrm{~S}-02 \mathrm{E}-11 \mathrm{BD})$ to $110 \mathrm{mg} / \mathrm{L}(28 \mathrm{~S}-02 \mathrm{E}-$ $24 \mathrm{AC}$ and 29S-02W-15AC). The other two lakes had calcium and sulfate as the principal dissolved constituents and concentrations of dissolved solids of $140 \mathrm{mg} / \mathrm{L}$ (26S-02E-10AD) and $170 \mathrm{mg} / \mathrm{L}(25 \mathrm{~S}-02 \mathrm{E}-4 \mathrm{AC})$.

Concentrations of the herbicide atrazine were detected in lakes $25 \mathrm{~S}-02 \mathrm{E}-4 \mathrm{AC}(0.1 \mu \mathrm{g} / \mathrm{L})$, 26S-02E-10AD $(0.9 \mu \mathrm{g} / \mathrm{L}), 27 \mathrm{~S}-02 \mathrm{E}-11 \mathrm{BD}(1.8$ $\mu \mathrm{g} / \mathrm{L}), 28 \mathrm{~S}-02 \mathrm{E}-24 \mathrm{AC}(0.3 \mu \mathrm{g} / \mathrm{L})$, and $29 \mathrm{~S}-02 \mathrm{~W}$ $15 \mathrm{AC}(0.1 \mathrm{~g} / \mathrm{L})$. Atrazine is sold under the trade names AAtrex, Atrazine, and Atratol ${ }^{1}$ and is used primarily to control broadleaf weeds in corn and grain sorghum. It is relatively soluble in water at $33 \mathrm{mg} / \mathrm{L}$ (Meister and others, 1984) and persists in soil for 1 year or longer. The U.S. Environmental Protection Agency has issued a lifetime health advisory level of $3.0 \mu \mathrm{g} / \mathrm{L}$ for atrazine (U.S. Environmental Protection Agency, written commun., September 1987).

1 Use of trade names in this report is for identification purposes only and does not constitute an endorsement by the U.S. Geological Survey. 


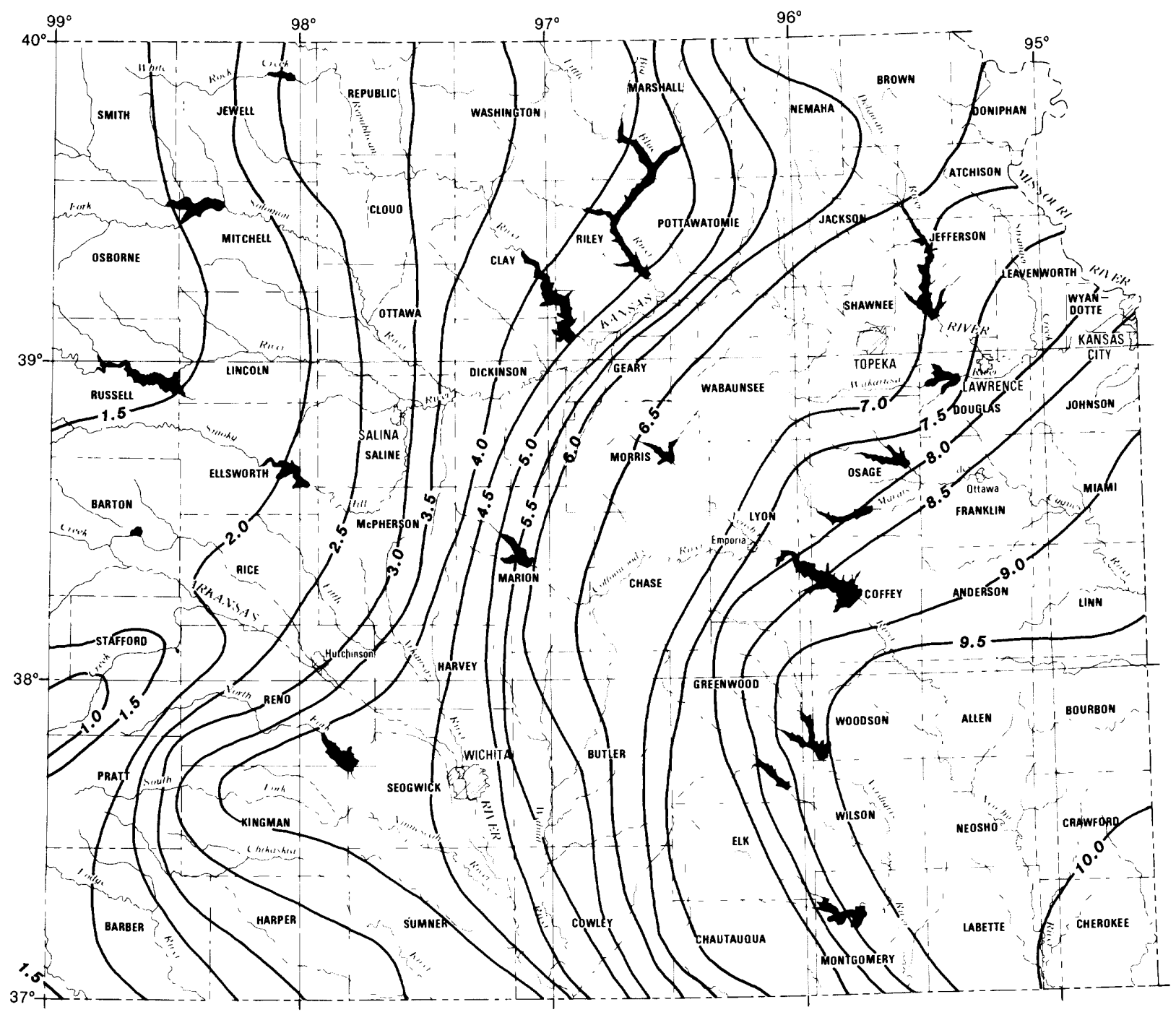

EXPLANATION

-2.0- LINE OF EQUAL RUNOFF--Interval 0.5 inch

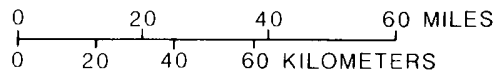

Figure 17. Mean annual runoff in eastern Kansas (modified from Carswell, 1982).

The herbicide cyanazine also was detected in the lake 27S-02E-11BD $(0.3 \mu \mathrm{g} / \mathrm{L})$. Cyanazine is sold under the trade name Bladex and is used as a preplant, preemergent, or postemergent herbicide for the control of weeds in field corn or for preemergent control of weeds in sorghum. Cyanazine is very soluble in water at $171 \mathrm{mg} / \mathrm{L}$ and persists in soil for about 1 year. The U.S. Environmental Protection Agency has issued a lifetime health advisory level of $9.0 \mu \mathrm{g} / \mathrm{L}$ for cyanazine (U.S. Environmental Protection Agency, written commun., August 1987).

Two lakes were sampled in parts of the county where the Ninnescah Shale occurs at or near the surface (26S-03W-19AC and 29S-04W$4 \mathrm{DC}$ ). These lakes were less than 9 feet deep and were very turbid, with transparencies of 2.5 inches. Calcium and bicarbonate were the principal dissolved constituents, and concentrations of dissolved solids were less than $45 \mathrm{mg} / \mathrm{L}$. The herbicides atrazine $(1.1 \mu \mathrm{g} / \mathrm{L})$, propazine $(0.1 \mu \mathrm{g} / \mathrm{L})$, and a degradation product of the insecticide heptachlor (heptachlor epoxide $=0.01 \mu \mathrm{g} / \mathrm{l})$ were detected in lake $26 \mathrm{~S}-03 \mathrm{~W}$ 19AC.

Propazine is sold under the trade names Milogard and Propazine and is used as a preemergent and preplant incorporated 


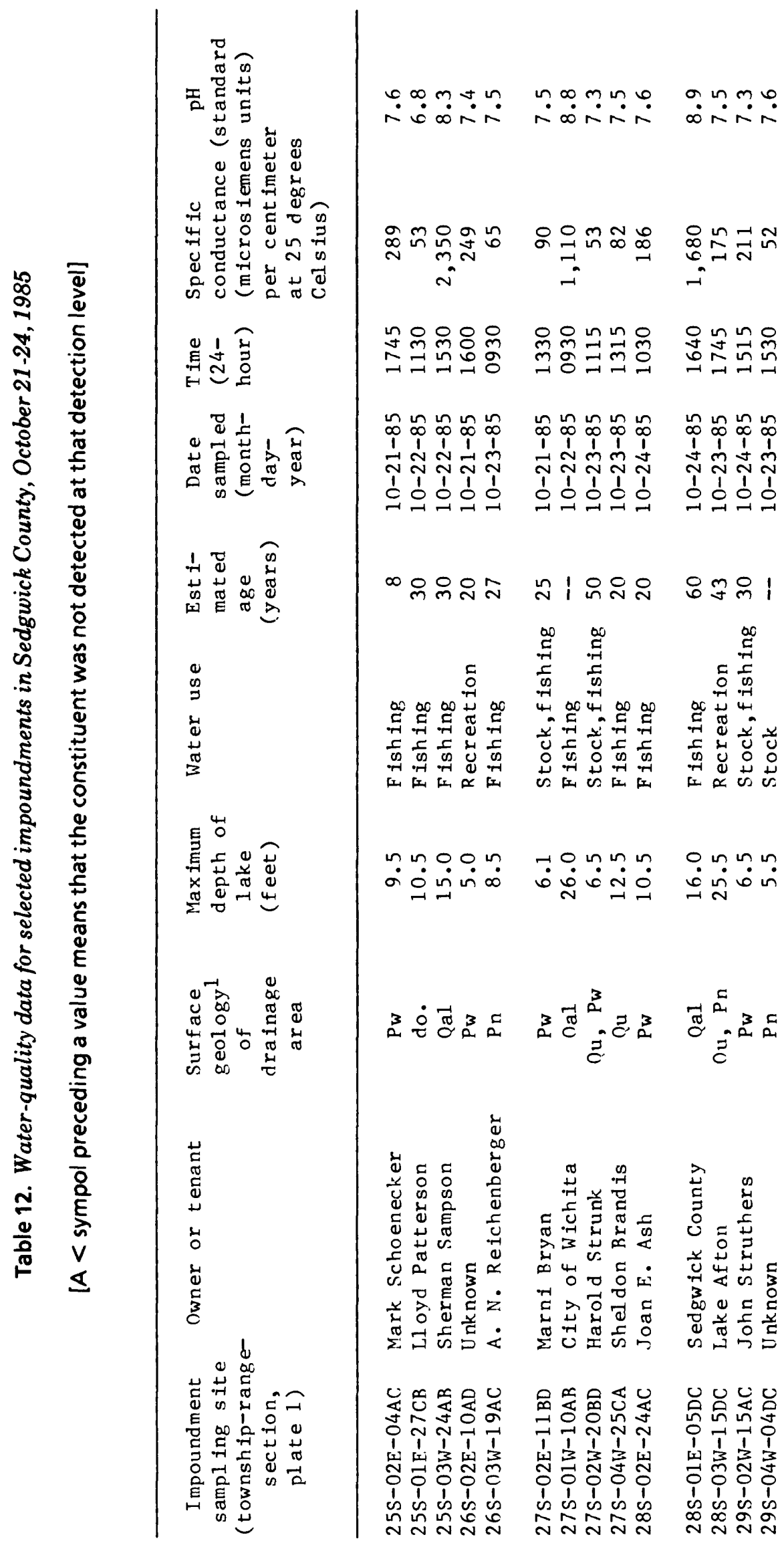




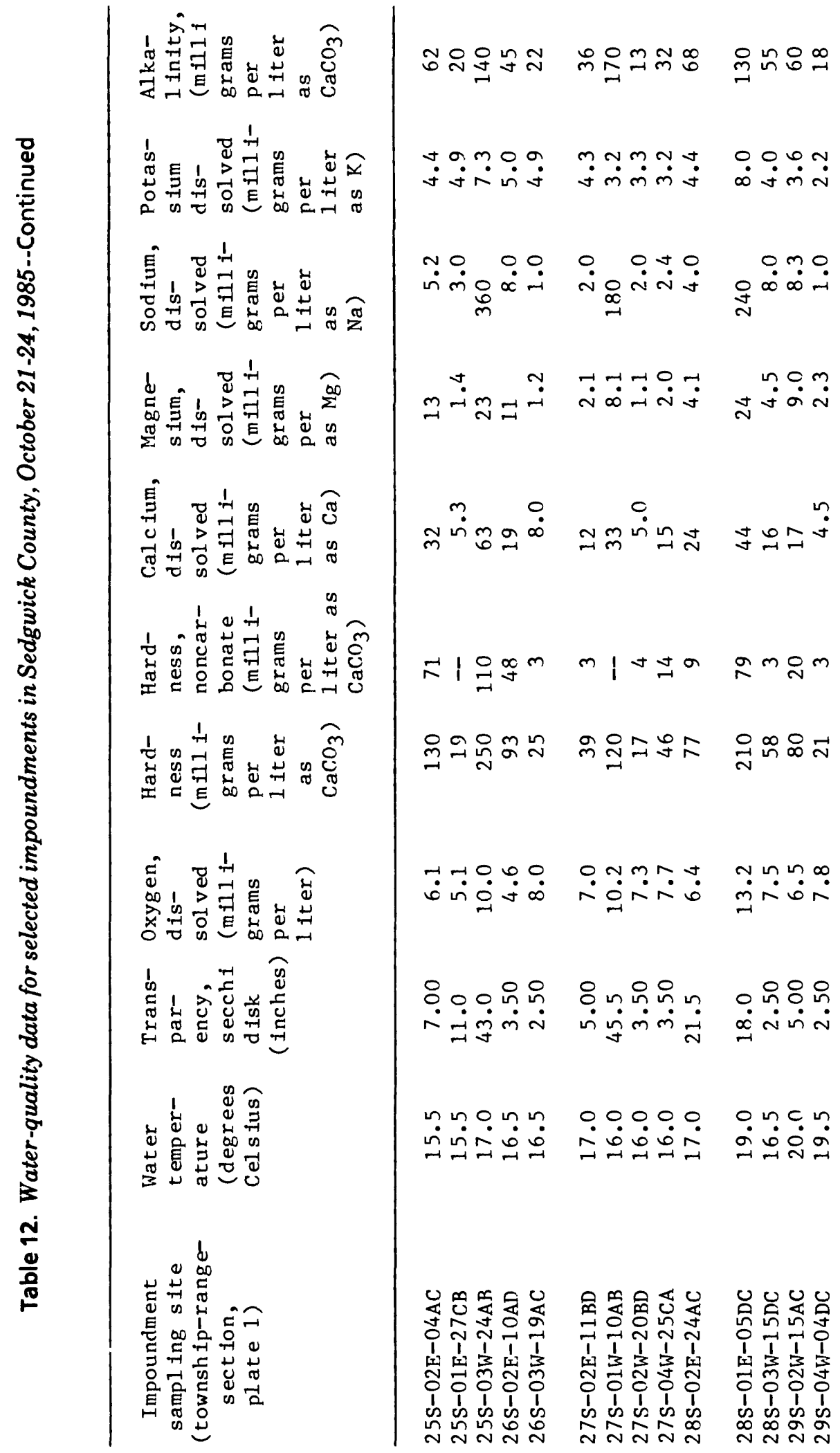




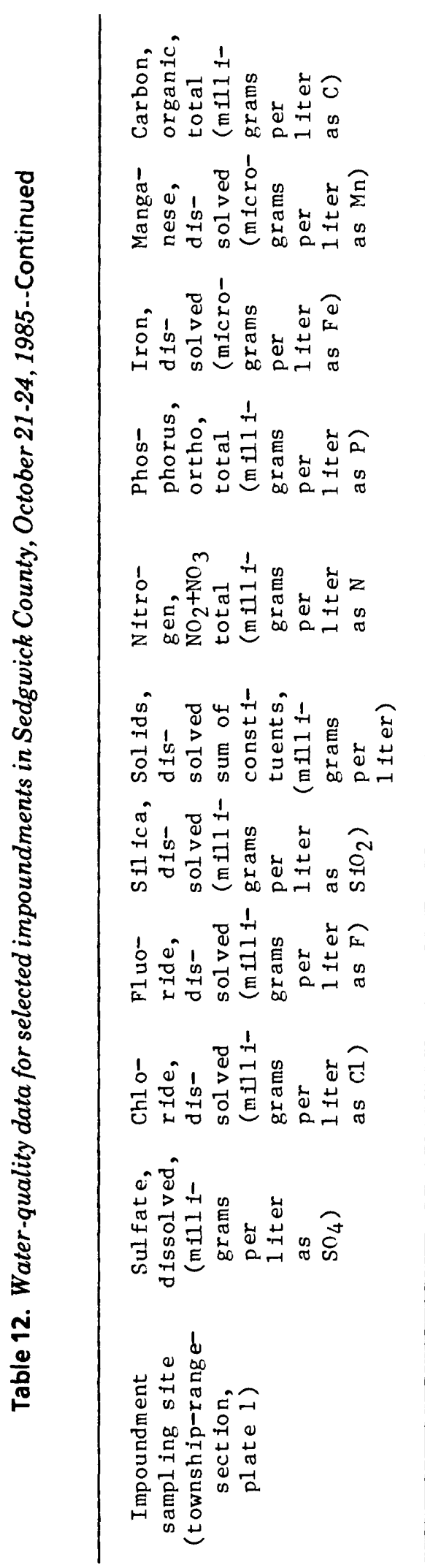

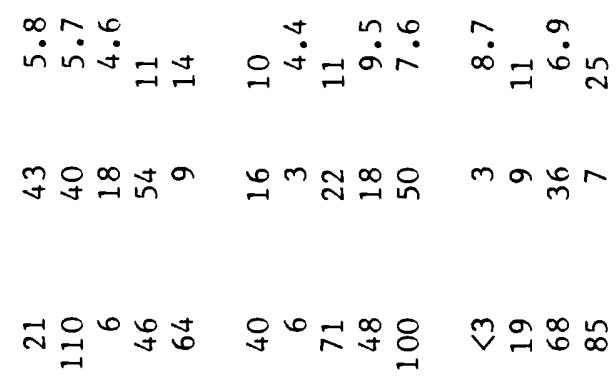

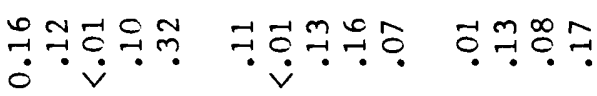

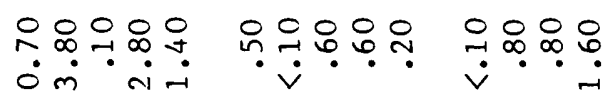

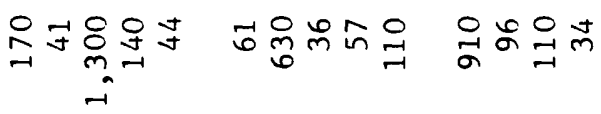

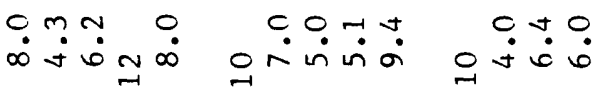

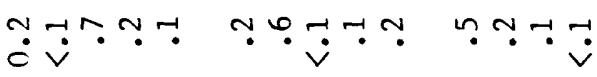

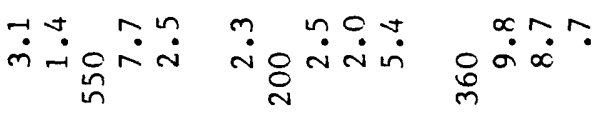

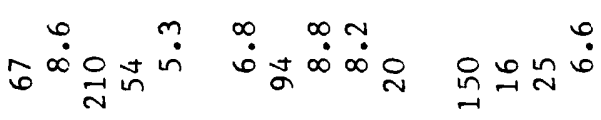

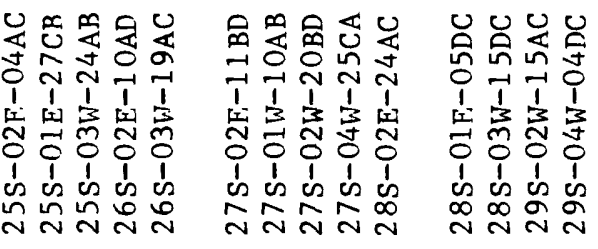




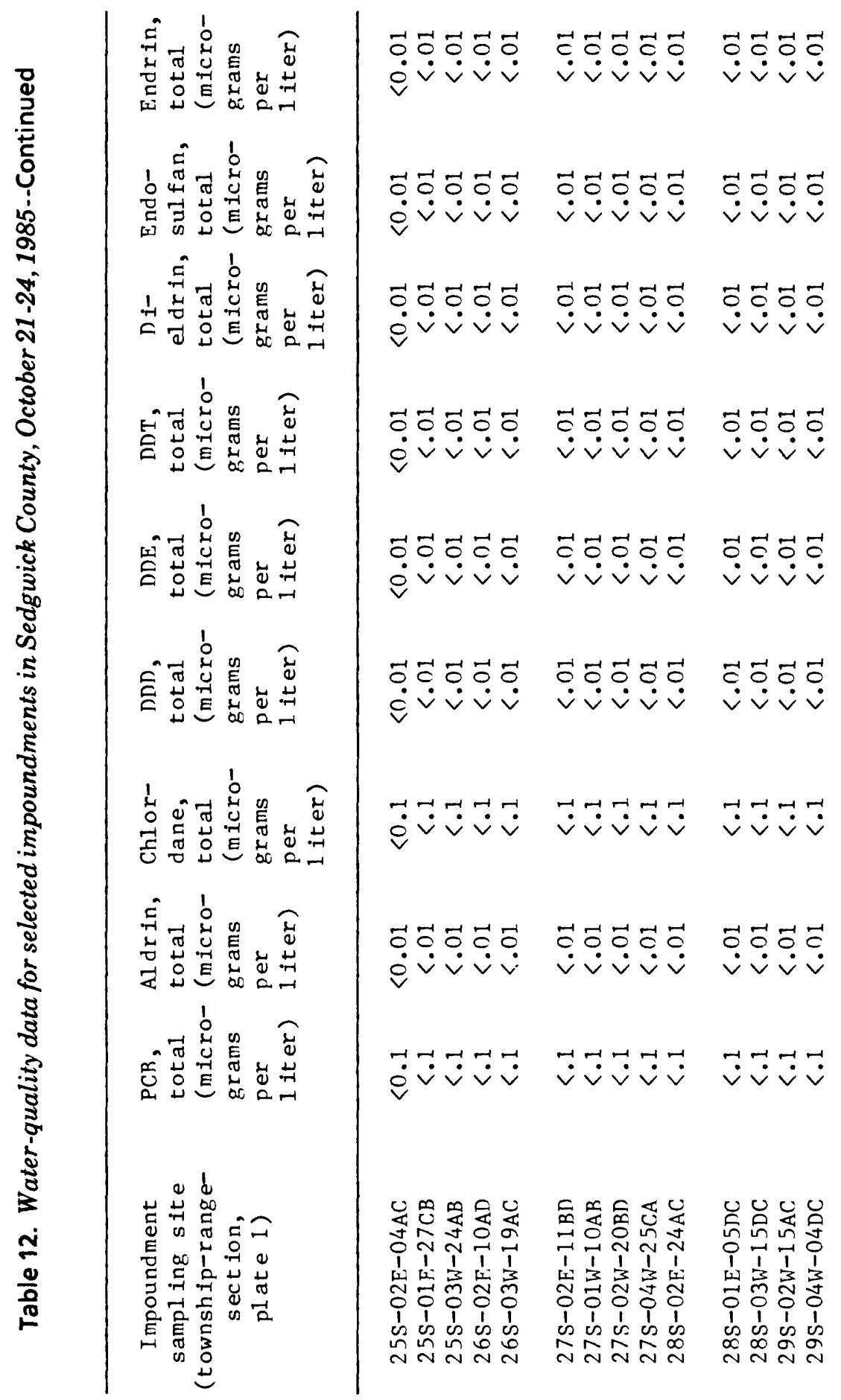




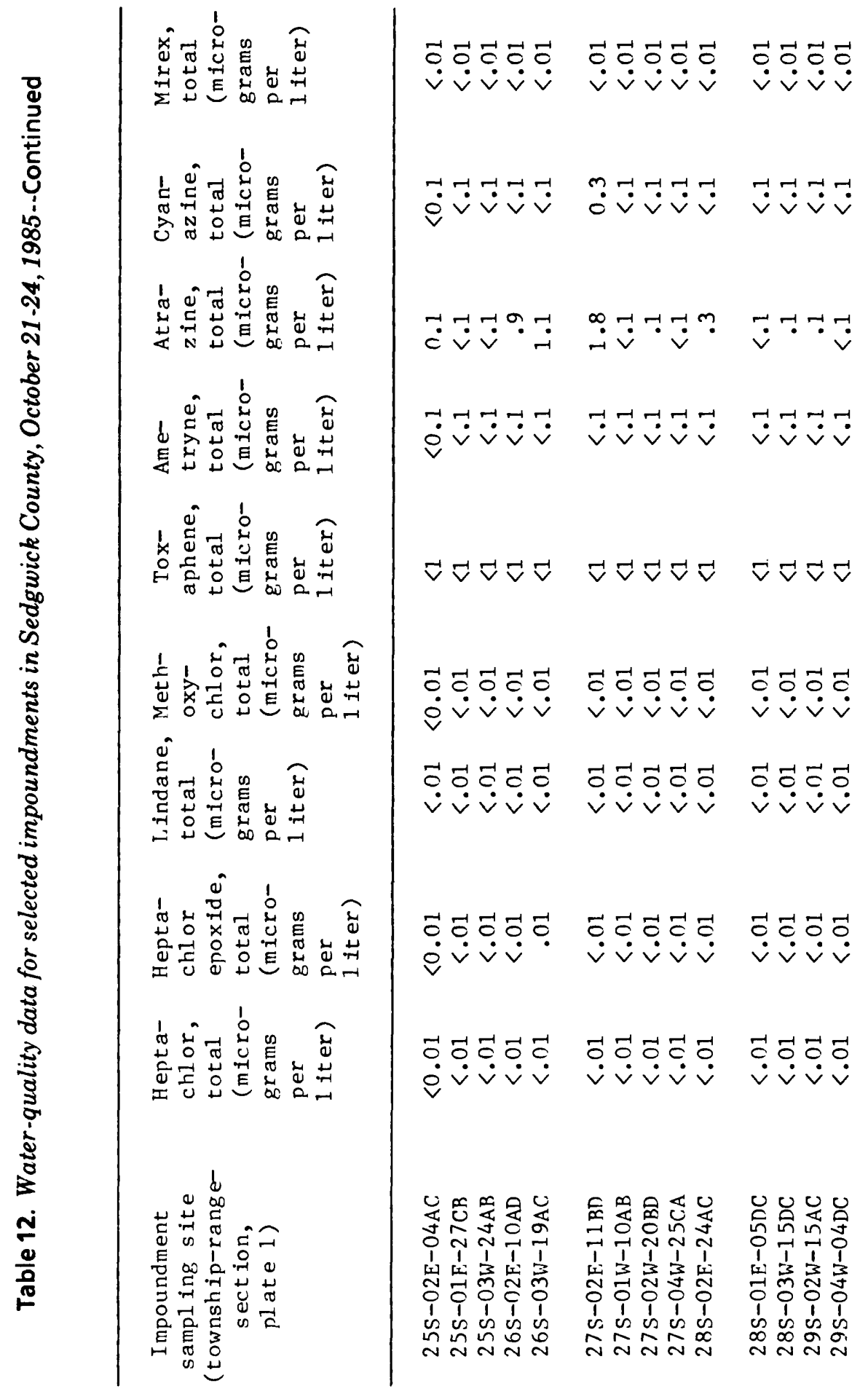




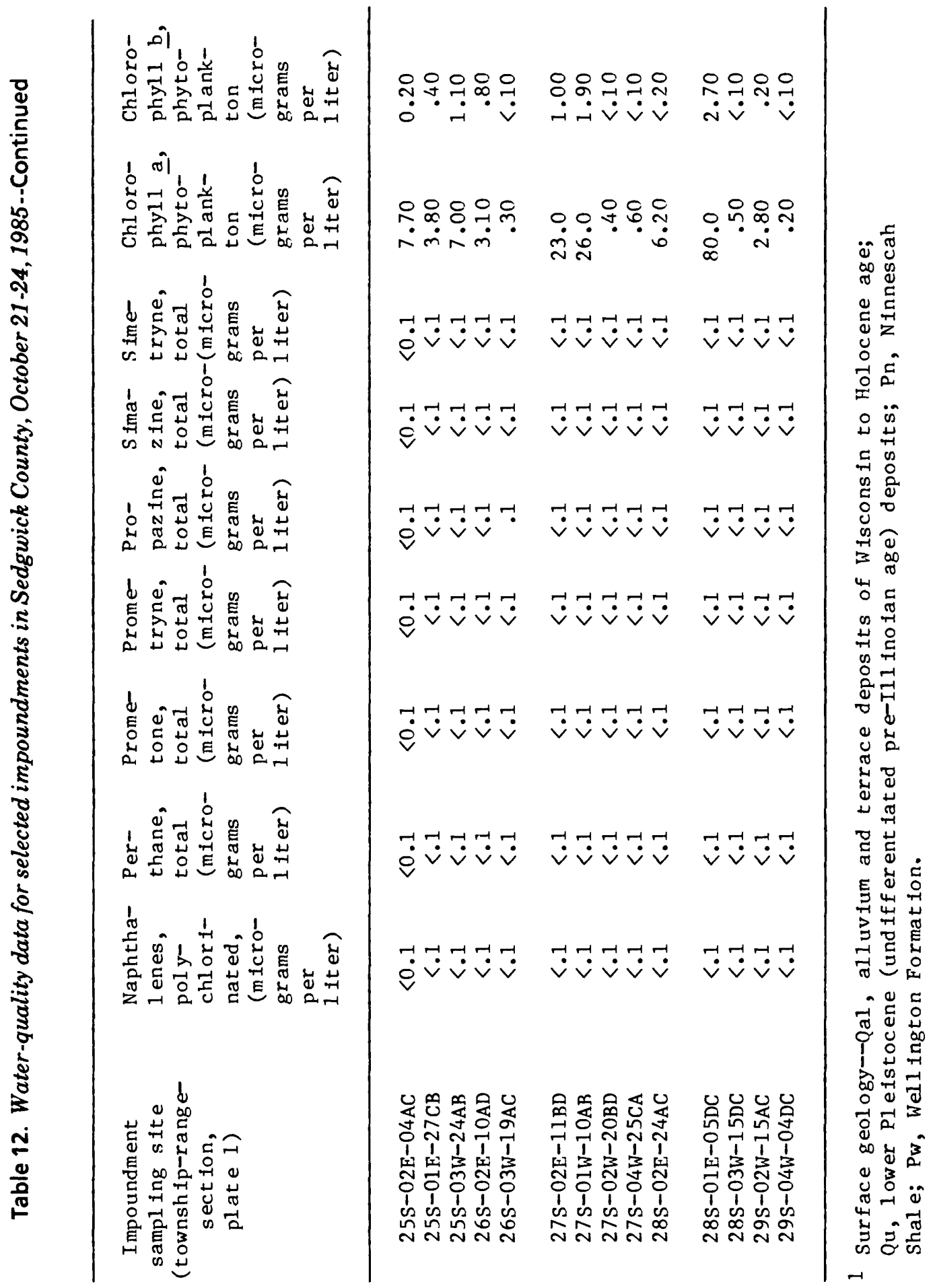


sorghum. Propazine is soluble in water at 8.6 $\mathrm{mg} / \mathrm{L}$ and persists in soil for 1 year or longer. The U.S. Environmental Protection Agency has issued a lifetime health advisory level of $14 \mu \mathrm{g} / \mathrm{L}$ for herbicide for the control of most annual broadleaf weeds and grasses in milo and sweet propazine (U.S. Environmental Protection Agency, written commun., August 1987).

Heptachlor is sold under the trade names Drinox H-34, Gold Crest H-60, Heptamul, and Heptox. It is used as an insecticide for subterranean termite control and some agricultural applications. Heptachlor is practically insoluble in water and persists in soil for as long as 3 years. The public-water supply criteria for heptachlor is $0.002 \mu \mathrm{g} / \mathrm{L}$ and for heptachlor epoxide is $0.1 \mu \mathrm{g} / \mathrm{L}$ (see table 2).

Three of the sampled lakes (27S-02W-20BD, 27S-04W-25CA, and 28S-03W-15DC or Lake Afton) receive most of their drainage from areas underlain by lower Pleistocene (undifferentiated pre-Illinoian age) deposits. These lakes ranged in depth from 6.5 feet (27S-02W-20BD) to 25.5 feet (Lake Afton) and were turbid, with transparencies of 3.5 inches or less. Calcium and bicarbonate were the principal dissolved constituents, and concentrations of dissolved solids ranged from $36 \mathrm{mg} / \mathrm{L}$ (27S-02W-20BD) and $57 \mathrm{mg} / \mathrm{L}(27 \mathrm{~S}-04 \mathrm{~W}-25 \mathrm{CA}$ ) to $96 \mathrm{mg} / \mathrm{L}$ (Lake Afton). Lake Afton probably receives more ground-water discharge, which results in a larger concentration of dissolved solids. The herbicide atrazine was detected in lake 27S02W-20BD $(0.1 \mu \mathrm{g} / \mathrm{L})$ and in Lake Afton $(0.1$ $\mu \mathrm{g} / \mathrm{L})$.

Three sandpit lakes (25S-03W-24AB, 27S$01 \mathrm{~W}-10 \mathrm{AB}$, and 28S-01E-05DC) were sampled in the vicinity of the Arkansas River. These lakes occur in areas underlain by alluvium and terrace deposits of Wisconsin to Holocene age. The sandpit lakes were quite different from other lakes sampled in the county. All of the other lakes that were sampled were formed by the construction of earthfill dams across stream channels, whereas the sandpit lakes were dug in areas where the ground water was shallow. Consequently, the sandpit lakes receive little surface runoff and contain mostly ground water. These lakes generally were deeper than most of the other lakes sampled, with depths ranging from 15 to 26 feet, and were relatively clear, with secchi disk depths ranging from 18 to 45.5 inches. The transparency values of these sandpit lakes are large because they receive little surface runoff to transport suspended sediment into them. The lake with the smallest transparency value (28S-01E-05DC) had a very significant density of phytoplankton, as evidenced by the chlorophyll- $a$ concentration of $80 \mu \mathrm{g} / \mathrm{L}$, which was three times larger than any other sampled lake and caused the decreased transparency. The sandpit lakes contained sodium chloride type water, with concentrations of dissolved solids that ranged from $630 \mathrm{mg} / \mathrm{L}(27 \mathrm{~S}-01 \mathrm{~W}$ $10 \mathrm{AB})$ to $1,300 \mathrm{mg} / \mathrm{L}(25 \mathrm{~S}-03 \mathrm{~W}-24 \mathrm{AB})$. Concentrations of nitrite plus nitrate as nitrogen and orthophosphorus were smaller in the sandpit lakes than in the other lakes sampled possibly because these nutrients often are introduced by surface runoff or because of nutrient uptake by phytoplankton and macrophytes. No pesticides were detected in these lakes.

Estimated water-quality characteristics of hypothetical impoundments on Little Arkansas and South Fork Ninnescah Rivers

The Little Arkansas and South Fork Ninnescah Rivers have long been considered as sources of water supplies for residents of the city of Wichita and Sedgwick County. Although the median and ranges of constituent concentrations that occur in these streams as presented in the section on "Statistical Summary of WaterQuality Properties and Constituents" are adequate for describing the water-quality characteristics of streams, those values are not representative of water-quality characteristics for impoundments that might be constructed on the streams. The maximum and minimum values of constituent concentrations observed in the streams would not occur in impoundments because they would be integrated with the continum of stream constituent concentrations as the water is impounded. The median constituent concentrations observed in the stream would correspond to values that occur during median streamflow if the data are representative. However, most of the impounded water would result from high streamflow.

The water-quality characteristics that can be used for determining the adequacy of an impoundment for water supplies are the mean concentration of dissolved solids and the rate of 
sediment deposition. The mean concentration of dissolved solids is a good general indicator of the quality of the impounded water.

An estimate of the mean concentration of dissolved solids that would occur in impoundments on the Little Arkansas River at Valley Center and the South Fork Ninnescah River near Murdock can be calculated by dividing the mean annual discharge of dissolved solids (provided in table 10) by the corresponding mean annual streamflow. The mean annual discharge of dissolved solids for the Little Arkansas River at Valley Center of 79,600 tons $\left(7.22 \times 10^{13}\right.$ milligrams) divided by the mean annual streamflow of $1.15 \times 10^{10}$ cubic feet (3.26 $\mathrm{X} 10^{11}$ liters) gives a mean annual dissolvedsolids concentration of about $220 \mathrm{mg} / \mathrm{L}$ that would occur in an impoundment, assuming that all the streamflow is impounded. The mean annual discharge of dissolved solids for the South Fork Ninnescah River near Murdock of 112,000 tons (1.02 $\times 10^{14}$ milligrams) divided by the mean annual streamflow of $6.46 \times 10^{9}$ cubic feet (1.83 X $10^{11}$ liters) gives a mean annual dissolved-solids concentration of about $560 \mathrm{mg} / \mathrm{L}$. These computed concentrations are significantly smaller than the observed median concentrations for the Little Arkansas River at Valley Center $(480 \mathrm{mg} / \mathrm{L})$ and the South Fork Ninnescah River near Murdock $(760 \mathrm{mg} / \mathrm{L})$. Of course not all of the flow will be impounded, but regulation of the impoundments can cause concentrations of dissolved solids to remain smaller than median concentrations in the contributing streams.

The mean annual discharge of suspended sediment for the Little Arkansas River at Valley Center (299,000 tons) and the South Fork Ninnescah River near Murdock (107,000 tons), presented in table 10, can be used to estimate the sedimentation rate of impoundments on these streams. Sedimentation decreases the amount of storage in an impoundment and, in Kansas, is the limiting factor in determining the duration of the impoundment's effective use for storage of water supplies. Assuming a 90percent sediment-trap efficiency, an impoundment on the Little Arkansas River at Valley Center would accumulate sediment at a rate of about 269,000 tons per year, and an impoundment on the South Fork Ninnescah River near Murdock would accumulate sediment at a rate of about 96,300 tons per year. Assuming that most of the sediment in these streams is clay and silt, the specific weight of the sediments would range between about 40 and 75 pounds per cubic foot after 50 years of accumulation (Linsley and others, 1975). Therefore, an impoundment on the Little Arkansas River at Valley Center could lose about 160 to 310 acre-feet of storage per year, and an impoundment on the South Fork Ninnescah River near Murdock could lose about 59 to 110 acre-feet of storage per year.

\section{Cheney Reservoir}

Cheney Reservoir, which is located on the North Fork Ninnescah River primarily in southeastern Reno County (fig. 1), is a principal source of public-water supplies for Wichita and for adjacent communities and rural water districts served by the Wichita Water Utility. The reservoir was completed in 1964 by the U.S. Bureau of Reclamation. The dam is approximately 20 miles west of Wichita and controls runoff from 901 square miles, of which probably only 664 square miles contribute. The reservoir has a total storage capacity of 566,300 acre-feet of water. The controlled storage total is 247,950 acre-feet and is allocated for sediment storage (980 acre-feet), fish and wildlife $(14,310$ acre-feet), conservation pool (151,800 acre-feet), and flood-control pool $(80,860$ acre-feet). When the reservoir is filled to the top of the conservation pool, it has a surface area of 9,540 acres; at the top of the flood-control pool, the reservoir has a surface area of 12,420 acres (U.S. Army Corps of Engineers, 1973). The capacity table for this reservoir, which relates the elevation of water to reservoir content, is based on a 1965 survey by the U.S. Bureau of Reclamation. More than 20 years of sediment deposition undoubtedly has changed this rating. If the same assumptions are used as in the preceding section concerning hypothetical reservoirs, approximately 290 to 530 acre-feet of storage may have been lost due to sedimentation during 1965 through 1986 (22 years). This is only a rough approximation, and a new survey would be required to accurately determine the amount of sediment deposition.

The city of Wichita has appropriated rights to annually withdraw as much as $\mathbf{5 2 , 6 0 0}$ acre-feet of water from Cheney Reservoir for 
public-water supplies. During 1985, Wichita withdrew about 18,300 acre-feet of water from the reservoir (data from city of Wichita). From 1966, when Wichita began withdrawing water from the reservoir, through 1985 , the city of Wichita had withdrawn a total of about 322,610 acre-feet of water from Cheney Reservoir. It is estimated that during a 2-year drought the yield from the reservoir would be limited to about 42,600 acre-feet per year (Lorenz and others, 1985).

Raw water from Cheney Reservoir and the Wichita well field are mixed prior to treatment at the Wichita water-treatment plant. Because of the relatively high turbidity of water from Cheney Reservoir, a mixture of 30-percent Cheney Reservoir water and 70-percent Wichita well field water is considered the optimum blend prior to treatment (Lorenz and others, 1985). The appropriated water right from the well field is about 40,000 acre-feet per year. To achieve the optimum blend of water at the water-treatment plant requires that only about 17,000 acre-feet of water from Cheney Reservoir be used on an annual basis if the total appropriated right from the well field is used. This is the current (1986) situation. A pretreatment facility to remove sediment from Cheney Reservoir water prior to blending with well-field water would allow much more of the appropriated water right from the reservoir to be used.

The water-quality characteristics of Cheney Reservoir are indicated by the mean values of selected water-quality properties and constituents given in table 13. The U.S. Geological Survey data are analyses of 14 samples collected from the North Fork Ninnescah River at Cheney Dam while water was being released from Cheney Reservoir during October 1965 through September 1985. The city of Wichita data are analyses of weekly composite samples (52) collected from the watersupply intake at Cheney Reservoir during 1985. The mean values of chemical constituents for the two data sets are very similar. The water is a sodium chloride type. An estimate of the mean concentration of dissolved solids, based on the mean values of major constituents shown in table 13 , is about $500 \mathrm{mg} / \mathrm{L}$. Potassium, fluoride, and nitrate are not included in the estimate of dissolved-solids concentration; however, concentrations of these constituents generally are very small, and the error introduced by excluding them probably is very small.

\section{GROUND-WATER RESOURCES}

\section{Occurrence and Availability}

Although ground water is present in the subsurface throughout Sedgwick County, the hydrogeologic properties of rocks determine the availability of water. In general, saturated unconsolidated deposits yield much greater quantities of water than saturated bedrock in the county. Most of the bedrock consists of finegrained shale, silty shale, and siltstone. The fine-grained consolidated nature of the bedrock hinders the movement of water and limits recharge and yields to wells.

The Wellington Formation of Permian age is present throughout the county. Where it occurs at or near the surface, on both sides of the Arkansas River valley, it is utilized as a source of self-supplied domestic and stock water. Wells completed in shale of the Wellington Formation generally yield less than 10 gallons per minute. However, in areas where the weathered upper surface of the Wellington Formation is saturated, yields may be greater. Moderately large yields, as much as $\mathbf{3 5 0}$ gallons per minute, can be obtained from wells penetrating gypsum or anhydrite solution channels (Lane and Miller, 1965a). Water in solution channels is usually confined (artesian).

In the area underlying the Arkansas River valley, the Hutchinson Salt Member of the Wellington Formation has been removed by dissolution processes resulting in solution cavities and greatly fractured collapsed beds. This part of the formation has been referred to as the Wellington aquifer and can yield large quantities of very saline water (Gogel, 1981).

The Ninnescah Shale, also of Permian age, occurs at or near the surface in the western one-third of the county. Wells completed in the Ninnescah Shale generally yield only small quantities of water, less than 10 gallons per minute. However, in areas where the upper weathered surface of the Ninnescah Shale is saturated, yields to wells may be greater. The Ninnescah Shale is utilized as a source of selfsupplied domestic and stock water in the western 
Table 13. Mean values of selected properties and concentrations of chemical constituents in water from Cheney Reservoir

[U.S. Geological Survey samples (14) were collected from the Ninnescah River at Cheney Dam during releases from Cheney Reservoir October 1965-September 1985; City of Wichita samples (52) were collected from the water-supply intake at Cheney Reservoir, near the dam, during 1985 and are weekly composite samples]

\begin{tabular}{|c|c|c|c|c|c|c|c|c|c|}
\hline \multirow[t]{2}{*}{ Source of analyses } & \multirow[b]{2}{*}{$\begin{array}{l}\text { Specif ic- } \\
\text { conductance, } \\
\text { in micro- } \\
\text { siemens per } \\
\text { cent imeter } \\
\text { at } 25 \text { degrees } \\
\text { Cels ius }\end{array}$} & \multirow[b]{2}{*}{$\begin{array}{l}\mathrm{pH}, \\
\text { stand- } \\
\text { ard } \\
\text { units }\end{array}$} & \multicolumn{2}{|c|}{ Concentration of } & \multirow{2}{*}{$\frac{\text { chemical }}{\text { Sod ium }}$} & \multirow{2}{*}{$\frac{\text { constituents, in }}{\text { Bicarbonate }}$} & \multicolumn{2}{|c|}{ mill igrams per 1 ite } & \multirow[b]{2}{*}{ S 11 ica } \\
\hline & & & Calc lum & Magnesium & & & Sulfate & ChIoride & \\
\hline $\begin{array}{l}\text { U.S. Geological } \\
\text { Survey }\end{array}$ & 956 & 7.8 & 52 & 15 & 120 & 190 & 51 & 180 & 6.2 \\
\hline City of Wichita & 788 & 7.4 & 54 & 16 & -- & 200 & 51 & 150 & 10 \\
\hline
\end{tabular}

part of Sedgwick County where it is not overlain by saturated unconsolidated alluvium, terrace deposits, or lower Pleistocene deposits (undifferentiated pre-Illinoian age) that are better sources of water (Lane and Miller, 1965a). Lower Pleistocene deposits (undifferentiated preIllinoian age) that occur on the southwardsloping uplands north of the Ninnescah River are utilized as sources of self-supplied domestic and stock water and as a source of public-water supplies for the city of Goddard. These deposits can yield as much as $\mathbf{5 0}$ gallons per minute (Lane and Miller, 1965a). Lower Pleistocene deposits that occur in the Arkansas River valley will be discussed in conjunction with other unconsolidated deposits in the valley.

Unconsolidated deposits in the Arkansas River valley range in age from Pliocene to Holocene. Undifferentiated Pliocene and lower Pleistocene (pre-Illinoian age) deposits generally occur under Illinoian terrace deposits and alluvium and terrace deposits of Wisconsin to Holocene age. Wells that are completed through the entire thickness of the deposits and screened in the more permeable sections can yield as much as 2,000 gallons per minute (Lane and Miller, 1965a). Shallower irrigation, stock, or domestic wells screened only in the Illinoian terrace deposits yield from 500 to 1,000 gallons per minute (Lane and Miller, 1965a). Unconsolidated alluvium and terrace deposits of Wisconsin to Holocene age that occur in the Ninnescah River valley are thinner and generally less permeable than those in the
Arkansas River valley (Lane and Miller, 1965a). Public-supply wells in Illinoian terrace deposits at Clearwater can yield about 270 gallons per minute, and wells in the buried valley located in the southwest corner of Sedgwick County can yield an estimated 50 to 100 gallons per minute.

Unconsolidated deposits of loess and colluvium generally are above the water table. Loess is very fine-grained, well-sorted, and has a small permeability but can yield small quantities of water if it lies below the water table. Colluvium (mainly silt but may contain sand, gravel, and bedrock fragments) can yield small quantities of water if it lies below the water table.

\section{Water Levels and Ground-Water Flow}

Water levels were measured at 335 wells in Sedgwick County during December 1985 and January 1986. The location, depth to water, land-surface elevation, ground-water elevation, and supporting information (owner or tenant, water use, depth of well, geologic source, and pertinent remarks) for these wells are given in table 14. The wells are plotted on plate 2. Plate 2 also shows depth to water and the groundwater elevation for each measured well and has ground-water-level contours (lines of equal ground-water elevation) that were drawn from interpretations of individual well measurements, geology, and topography. 
Table 14. Records of wells where water-level measurements were made during December 1985 and January 1986

\begin{tabular}{|c|c|c|c|c|c|c|c|c|c|c|c|}
\hline \multirow[b]{2}{*}{$\begin{array}{l}\text { Well } \\
\text { number } \\
\text { (township- } \\
\text { range- } \\
\text { section, } \\
\text { plate 2) }\end{array}$} & \multirow{2}{*}{\multicolumn{2}{|c|}{ Owner or tenant }} & \multirow[b]{2}{*}{$\begin{array}{l}\text { Wat er } \\
\text { use } \mathrm{e}^{1}\end{array}$} & \multirow[b]{2}{*}{$\begin{array}{l}\text { Depth } \\
\text { of well } 1 \\
\text { (f eet) }\end{array}$} & \multicolumn{2}{|c|}{$\begin{array}{c}\text { Principal water-bearing } \\
\text { units }\end{array}$} & \multirow[b]{2}{*}{$\begin{array}{l}\text { Date of } \\
\text { measure- } \\
\text { ment } \\
\text { (month- } \\
\text { day- } \\
\text { year) }\end{array}$} & \multirow[b]{2}{*}{$\begin{array}{l}\text { Land- } \\
\text { sur- } \\
\text { face } \\
\text { el eva- } \\
\text { tion } \\
\text { (f eet } \\
\text { above } \\
\text { s ea } \\
\text { level) }\end{array}$} & \multirow[b]{2}{*}{$\begin{array}{l}\text { Depth } \\
\text { to } \\
\text { ground- } \\
\text { wat er } \\
\text { (f eet) } \\
\end{array}$} & \multirow[b]{2}{*}{$\begin{array}{l}\text { Ground- } \\
\text { water } \\
\text { l evel } \\
\text { (f eet } \\
\text { above } \\
\text { sea } \\
\text { level) }\end{array}$} & \multirow[b]{2}{*}{$\begin{array}{c}\text { Remarks } \\
\text { (MW = owner or } \\
\text { tenant monitor } \\
\text { wells; QW = water- } \\
\text { qual ity data in } \\
\text { tabl e } 15 ; \\
\text { gal } / \mathrm{m} \text { in = gallons } \\
\text { per minute) }\end{array}$} \\
\hline & & & & & $\begin{array}{c}\text { Character } \\
\text { of material }\end{array}$ & $\begin{array}{l}\text { Geol og ic } \\
\text { source }\end{array}$ & & & & & \\
\hline $25 \mathrm{~S}-02 \mathrm{E}-22 \mathrm{BBB}$ & Euger & ne Thompson & $\mathrm{D}$ & 90.0 & Shal e & $\mathrm{Pw}$ & $12-06-85$ & 1,400 & 44.3 & 1,356 & \\
\hline $25 S-02 E-31 D D A$ & Harry & y Newsum & $\mathrm{D}$ & 85.0 & Sand, shale & $\mathrm{Q} 1, \mathrm{Pw}_{\mathrm{w}}$ & $12-06-85$ & 1,440 & 15.2 & 1,425 & \\
\hline $25 \mathrm{~S}-01 \mathrm{E}-15 \mathrm{DDC}$ & Wayn & e E Means & $\mathrm{s}$ & 45.0 & do. & do. & $12-06-85$ & 1,432 & 15.2 & 1,417 & \\
\hline $25 \mathrm{~S}-01 \mathrm{E}-18 \mathrm{CDC}$ & Lyle & Kal p & $D$ & 45.0 & do. & do. & $12-06-85$ & 1,382 & 16.7 & 1,365 & \\
\hline $25 \mathrm{~S}-01 \mathrm{E}-24 \mathrm{DCD}$ & Don $\mathrm{T}$ & Tideman & D & 78.0 & Shal e & $\mathrm{Pw}$ & $12-06-85$ & 1,400 & 8.7 & 1,391 & $\begin{array}{l}\text { Yields } 10 \mathrm{gal} / \mathrm{min} \text {; } \\
\text { QW }\end{array}$ \\
\hline $\begin{array}{l}25 S-01 E-29 C B C \\
25 S-01 E-31 C D B\end{array}$ & Georg & ge Bradshaw & $\stackrel{D}{D}$ & 65.0 & $\begin{array}{l}\text { Sand, shal e } \\
\text { Sand }\end{array}$ & $\mathrm{Q} 1, \mathrm{Pw}_{\mathrm{w}}$ & $12-06-85$ & 1,390 & 36.9 & 1,353 & \\
\hline $25 \mathrm{~S}-01 \mathrm{~W}-03 \mathrm{AAA}$ & $\begin{array}{l}\text { Lynn } \\
\text { City }\end{array}$ & of Wichita & $\begin{array}{c}20,0 \\
0\end{array}$ & 25.1 & Sand, gravel & do. & $\begin{array}{l}12-06-85 \\
01-01-86\end{array}$ & $\begin{array}{l}1,341 \\
1,383\end{array}$ & $\begin{array}{r}13.9 \\
8.3\end{array}$ & $\begin{array}{l}1,321 \\
1,375\end{array}$ & MW 825 \\
\hline $25 \mathrm{~S}-01 \mathrm{~W}-05 \mathrm{AAA}$ & & do. & 0 & 18.2 & $\begin{array}{l}\text { do. } \\
\text { do. }\end{array}$ & do. & $01-01-86$ & 1,368 & 10.2 & 1,358 & MW 826 \\
\hline $25 \mathrm{~s}-01 \mathrm{~W}-05 \mathrm{CCC}$ & & do. & 0 & 32.5 & do. & do. & $01-01-86$ & 1,375 & 22.6 & 1,352 & MW 1176 \\
\hline $25 \mathrm{~S}-01 \mathrm{~W}-05 \mathrm{DDD}$ & & do. & 0 & 70.0 & do. & Qal, OT & $01-01-86$ & 1,371 & 19.5 & 1,351 & MW 124 \\
\hline $25 \mathrm{~S}-01 \mathrm{w}-06 \mathrm{CCC}$ & & do. & 0 & 85.0 & do. & do. & $01-01-86$ & 1,380 & 28.3 & 1,352 & MW M34b \\
\hline $25 S-01 w-06 C D D$ & & do. & 0 & 86.0 & do. & do. & $01-01-86$ & 1,382 & 31.4 & 1,351 & MW M35b \\
\hline $25 \mathrm{~S}-01 \mathrm{w}-07 \mathrm{BCC}$ & & do. & 0 & 51.0 & do. & Qal & $01-01-86$ & 1,381 & 30.3 & 1,351 & MW M36b \\
\hline $25 \mathrm{~S}-01 \mathrm{~W}-07 \mathrm{CcC}$ & & do. & 0 & 31.1 & do. & do. & $01-01-86$ & 1,381 & 28.6 & 1,352 & MW 816 \\
\hline $25 s-01 W-10 \mathrm{ccc}$ & & do. & 0 & 68.5 & do. & Qa1, QT & $01-01-86$ & 1,361 & 11.6 & 1,349 & MW 125 \\
\hline $25 \mathrm{~S}-01 \mathrm{~W}-17 \mathrm{AAA}$ & & do. & 0 & 30.7 & do. & Qal & $01-01-86$ & 1,370 & 21.3 & 1,349 & MW 815 \\
\hline $25 \mathrm{~S}-01 \mathrm{~W}-17 \mathrm{CBB}$ & & do. & 0 & 52.0 & do. & do. & $01-01-86$ & 1,371 & 21.8 & 1,349 & MW M39b \\
\hline $25 \mathrm{~s}-01 \mathrm{~W}-17 \mathrm{CCC}$ & & do. & 0 & 43.0 & do. & do. & $01-01-86$ & 1,370 & 20.1 & 1,350 & MW $\mathrm{M} 40 \mathrm{~b}$ \\
\hline $25 S-01 W-18 A A A$ & & do. & 0 & 48.0 & do. & do. & $01-01-86$ & 1,375 & 28.5 & 1,346 & MW $M 38 b$ \\
\hline $25 \mathrm{~S}-01 \mathrm{~W}-18 \mathrm{ABB}$ & & do. & 0 & 52.5 & do. & do. & $01-01-86$ & 1,375 & 26.1 & 1,349 & MW M37b \\
\hline $25 S-01 W-20 \mathrm{ccc}$ & & do. & 0 & 38.5 & do. & do. & $01-01-86$ & 1,371 & 15.8 & 1,355 & MW 117 \\
\hline $25 \mathrm{~S}-01 \mathrm{~W}-22 \mathrm{BBB}$ & & do. & 0 & 40.4 & do. & do. & $01-01-86$ & 1,359 & 13.1 & 1,346 & MW 126 \\
\hline $25 \mathrm{~S}-01 \mathrm{~W}-25 \mathrm{DDA}$ & Valle & ey Center School & o1 NU & 45.0 & do. & do. & $12-05-85$ & 1,348 & 12.4 & 1,336 & \\
\hline $25 \mathrm{~S}-01 \mathrm{~W}-26 \mathrm{DBD}$ & City & of Wichita & 0 & 54.0 & do. & do. & $01-01-86$ & 1,352 & 17.9 & 1,334 & MW 12 \\
\hline $25 \mathrm{~S}-01 \mathrm{~W}-27 \mathrm{BBB}$ & & do. & 0 & 25.3 & do. & do. & $01-01-86$ & 1,362 & 16.7 & 1,345 & MW 812 \\
\hline $25 \mathrm{~S}-01 \mathrm{~W}-31 \mathrm{AAA}$ & Mike & Ra jewsk 1 & D & 35.0 & do. & do. & $12-05-85$ & 1,365 & 12.3 & 1,353 & Yields $100 \mathrm{gal} / \mathrm{min}$ \\
\hline $25 \mathrm{~s}-01 \mathrm{w}-34 \mathrm{DCC}$ & Lou is & s Hendy & $\mathrm{D}$ & -- & do. & do. & $12-05-85$ & 1,352 & 11.6 & 1,340 & \\
\hline $25 S-01 W-35 D A A$ & City & of Wichita & 0 & 24.8 & do. & do. & $01-01-86$ & 1,347 & 15.9 & 1,331 & MW 810 \\
\hline $25 \mathrm{~S}-01 \mathrm{~W}-36 \mathrm{AAB}$ & Lel an & nd Johnson & $L \& G$ & 50.0 & Sand & do. & $12-05-85$ & 1,347 & 16.3 & 1,331 & \\
\hline $25 \mathrm{~S}-02 \mathrm{~W}-01 \mathrm{ADD}$ & City & of Wichita & 0 & 75.0 & Sand, gravel & Qal, QT & $01-01-86$ & 1,379 & 27.0 & 1,352 & MW M3 3b \\
\hline $25 \mathrm{~S}-02 \mathrm{~W}-01 \mathrm{BAA}$ & & do. & 0 & 51.0 & do. & Oal & $01-01-86$ & 1,384 & 28.2 & 1,356 & MW M25b \\
\hline $25 \mathrm{~S}-02 \mathrm{~W}-01 \mathrm{CBB}$ & & do. & 0 & 92.0 & do. & Qal, QT & $01-01-86$ & 1,388 & 31.5 & 1,356 & MW 307 \\
\hline $25 s-02 W-02 A B B$ & & do. & 0 & 82.0 & do. & do. & $01-01-86$ & 1,390 & 34.2 & 1,356 & MW M28b \\
\hline $25 \mathrm{~S}-02 \mathrm{~W}-03 \mathrm{AAA}$ & & do. & 0 & 80.0 & do. & do. & $01-01-86$ & 1,393 & 32.8 & 1,360 & MW M27b \\
\hline $25 \mathrm{~S}-02 \mathrm{~W}-03 \mathrm{CCC}$ & City & of Wichita & 0 & 26.0 & Sand, gravel & Qal & $01-01-86$ & 1,395 & 16.3 & 1,379 & MW 840 \\
\hline $25 \mathrm{~S}-02 \mathrm{~W}-04 \mathrm{AAA}$ & & do, & 0 & 20.1 & do. & do. & $01-01-86$ & 1,400 & 25.3 & 1,375 & MW 1171 \\
\hline $25 \mathrm{~S}-02 \mathrm{~W}-05 \mathrm{BBB}$ & & do. & 0 & 39.0 & do. & do. & $01-01-86$ & 1,408 & 11.9 & 1,396 & MW M51b \\
\hline $25 S-02 W-05 B C C$ & & do. & 0 & 40.3 & do. & do. & $01-01-86$ & 1,408 & 13.8 & 1,394 & MW M52b \\
\hline $25 S-02 W-05 C C D$ & & do. & 0 & 37.0 & do. & do. & $01-01-86$ & 1,402 & 12.6 & 1,389 & MW M $53 b$ \\
\hline $25 S-02 W-05 D B B$ & & do. & 0 & 40.0 & do. & do. & $01-01-86$ & 1,404 & 17.8 & 1,386 & MW M54b \\
\hline $25 \mathrm{~S}-02 \mathrm{~W}-05 \mathrm{DCD}$ & & do. & 0 & 40.0 & do. & do. & $01-01-86$ & 1,402 & 15.8 & 1,386 & MW M5 5b \\
\hline $25 \mathrm{~S}-02 \mathrm{~W}-07 \mathrm{AAA}$ & & do. & 0 & 32.0 & do. & do. & $01-01-86$ & 1,402 & 10.0 & 1,392 & MW 114 \\
\hline $25 \mathrm{~S}-02 \mathrm{~W}-11 \mathrm{ABB}$ & & do. & 0 & 61.0 & do. & do. & $01-01-86$ & 1,387 & 29.5 & 1,357 & $\mathrm{MW} \mathrm{M} 30 \mathrm{~b}$ \\
\hline $25 \mathrm{~s}-02 \mathrm{~W}-11 \mathrm{BBB}$ & & do. & 0 & 103.0 & do. & $\mathrm{Q} \mathbf{a} 1, \mathrm{QT}$ & $01-01-86$ & 1,391 & 27.0 & 1,364 & $M W M 29 b$ \\
\hline $25 S-02 W-12 B B A$ & & do. & 0 & 62.0 & do. & Qal & $01-01-86$ & 1,386 & 30.2 & 1,356 & MW M31b \\
\hline $25 \mathrm{~S}-02 \mathrm{~W}-12 \mathrm{BAA}$ & & do. & 0 & 61.0 & do. & do. & $01-01-86$ & 1,383 & 30.3 & 1,353 & MW $\mathrm{M} 32 \mathrm{~b}$ \\
\hline $25 \mathrm{~S}-02 \mathrm{~W}-13 \mathrm{BBC}$ & & do. & 0 & 65.0 & do. & do. & $01-01-86$ & 1,383 & 19.1 & 1,364 & MW 3045 \\
\hline $25 \mathrm{~S}-02 \mathrm{~W}-14 \mathrm{CCC}$ & & do. & 0 & 24.0 & do. & do. & $01-01-86$ & 1,384 & 7.7 & 1,376 & MW 3044 \\
\hline $25 \mathrm{~S}-02 \mathrm{~W}-16 \mathrm{BBB}$ & & do. & 0 & 15.0 & do. & do. & $01-01-86$ & 1,397 & 9.7 & 1,387 & MW 842 \\
\hline $25 \mathrm{~S}-02 \mathrm{~W}-18 \mathrm{AAB}$ & & do. & 0 & 19.0 & do. & do. & $01-01-86$ & 1,404 & 12.2 & 1,392 & MW 870 \\
\hline $25 \mathrm{~S}-02 \mathrm{~W}-22 \mathrm{BBB}$ & & do. & 0 & 32.0 & do. & do. & $01-01-86$ & 1,389 & 7.8 & 1,381 & MW 115 \\
\hline $25 \mathrm{~S}-02 \mathrm{~W}-22 \mathrm{DAA}$ & David & d Jacob & D & 32.0 & do. & do. & $12-04-85$ & 1,384 & 6.2 & 1,378 & \\
\hline $25 S-02 W-24 D D D$ & City & of Wichita & 0 & 20.0 & do. & do. & $01-01-86$ & 1,373 & 10.9 & 1,362 & MW 3050 \\
\hline $25 \mathrm{~S}-02 \mathrm{~W}-26 \mathrm{BAB}$ & Noel & Ramey & $\mathrm{D}$ & 130.0 & do. & Qa1, QT & $12-04-85$ & 1,381 & 6.9 & 1,374 & \\
\hline
\end{tabular}


Table 14. Records of wells where water-level measurements were made during December 1985 and January 1986--Continued

\begin{tabular}{|c|c|c|c|c|c|c|c|c|c|c|}
\hline \multirow[b]{2}{*}{$\begin{array}{l}\text { Wel1 } \\
\text { number } \\
\text { (township- } \\
\text { range- } \\
\text { section, } \\
\text { plate 2) }\end{array}$} & \multirow[b]{2}{*}{ Owner or tenant } & & \multirow[b]{2}{*}{$\begin{array}{l}\text { Depth } \\
\text { of well } 1 \\
\text { ( } f \text { eet) }\end{array}$} & \multicolumn{2}{|c|}{$\begin{array}{c}\text { Principal water-bearing } \\
\text { units }\end{array}$} & \multirow[b]{2}{*}{$\begin{array}{l}\text { Date of } \\
\text { measure- } \\
\text { ment } \\
\text { (month- } \\
\text { day- } \\
\text { year) }\end{array}$} & \multirow[b]{2}{*}{$\begin{array}{l}\text { Land- } \\
\text { sur- } \\
\text { face } \\
\text { el eva- } \\
\text { t lon } \\
\text { (f eet } \\
\text { above } \\
\text { s ea } \\
\text { level) }\end{array}$} & \multirow[b]{2}{*}{$\begin{array}{l}\text { Depth } \\
\text { to } \\
\text { ground- } \\
\text { - water } \\
\text { (f eet) } \\
\\
\text { ) }\end{array}$} & \multirow[b]{2}{*}{$\begin{array}{l}\text { Ground- } \\
\text { water } \\
\text { l evel } \\
\text { (f eet } \\
\text { above } \\
\text { s ea } \\
\text { level) }\end{array}$} & \multirow[b]{2}{*}{$\begin{array}{c}\text { Remarks } \\
\text { (MW = owner or } \\
\text { tenant monitor } \\
\text { wells; QW = water- } \\
\text { qual ity data in } \\
\text { table } 15 ; \\
\text { gal } / \mathrm{m} 1 \mathrm{n}=\text { gal lons } \\
\text { per minute }\end{array}$} \\
\hline & & & & $\begin{array}{l}\text { Character } \\
\text { of material }\end{array}$ & $\begin{array}{l}\text { Geologic } \\
\text { source }\end{array}$ & & & & & \\
\hline $\begin{array}{l}25 s-02 w-26 D D B \\
25 s-02 w-30 C C C \\
25 s-02 w-34 C \\
25 s-03 w-01 D D D \\
25 s-03 w-03 D D D\end{array}$ & $\begin{array}{l}\text { MLF Razier } \\
\text { C1ty of Wichita } \\
\text { Harold Korte } \\
\text { City of Wichita } \\
\text { do. }\end{array}$ & $\begin{array}{l}\mathrm{I} \\
0 \\
\mathrm{I} \\
0 \\
0\end{array}$ & $\begin{array}{l}--- \\
57.0 \\
-- \\
20.0 \\
17.2\end{array}$ & $\begin{array}{l}\text { Sand, gravel } \\
\text { do. } \\
\text { do. } \\
\text { do. } \\
\text { do. }\end{array}$ & $\begin{array}{l}\text { Qal } \\
\text { Qt } \\
\text { do. } \\
\text { Qal } \\
\text { do. }\end{array}$ & $\begin{array}{l}12-05-85 \\
01-01-86 \\
12-04-85 \\
01-01-86 \\
01-01-86\end{array}$ & $\begin{array}{l}1,374 \\
1,418 \\
1,381 \\
1,409 \\
1,423\end{array}$ & $\begin{array}{r}6.4 \\
28.9 \\
9.0 \\
10.8 \\
10.1\end{array}$ & $\begin{array}{l}1,368 \\
1,389 \\
1,372 \\
1,398 \\
1,413\end{array}$ & $\begin{array}{l}\text { MW } 830 \\
\text { MW } 3004 \\
\text { MW } 3041\end{array}$ \\
\hline $\begin{array}{l}25 s-03 w-05 B A B \\
25 s-03 w-08 D D D \\
25 s-03 w-09 C C C \\
25 s-03 w-14 C C C \\
25 s-03 w-15 C C C\end{array}$ & $\begin{array}{l}\text { Ronnie Young } \\
\text { Dale McCurry } \\
\text { C1ty of Wichita } \\
\text { Mt. Hope Trucking } \\
\text { Bob \& Rayle Ell lott }\end{array}$ & $\begin{array}{l}\mathrm{I} \\
\mathrm{D} \\
0 \\
\mathrm{D} \\
\mathrm{I}\end{array}$ & $\begin{array}{r}80.0 \\
65.0 \\
18.5 \\
59.0 \\
106.0\end{array}$ & $\begin{array}{l}\text { do. } \\
\text { do. } \\
\text { do. } \\
\text { do. } \\
\text { do. }\end{array}$ & $\begin{array}{l}\text { Qal, QT } \\
\text { Qt } \\
\text { do. } \\
\text { do. } \\
\text { Ot, QT }\end{array}$ & $\begin{array}{l}12-03-85 \\
12-03-85 \\
01-01-86 \\
12-02-85 \\
12-02-85\end{array}$ & $\begin{array}{l}1,435 \\
1,430 \\
1,430 \\
1,425 \\
1,428\end{array}$ & $\begin{array}{r}6.7 \\
6.5 \\
10.3 \\
18.1 \\
19.9\end{array}$ & $\begin{array}{l}1,428 \\
1,424 \\
1,420 \\
1,407 \\
1,408\end{array}$ & $\begin{array}{l}\text { QW } \\
\text { Yields } 50 \mathrm{gal} / \mathrm{min} \\
\text { MW } 834 \\
\text { Yields } 50 \mathrm{gal} / \mathrm{min} \\
\text { Ylelds } 2,000 \\
\quad \text { gal } / \mathrm{min}\end{array}$ \\
\hline $\begin{array}{l}25 S-03 W-17 B B C \\
25 s-03 W-21 B A B\end{array}$ & $\begin{array}{l}\text { Irwin Beal } \\
\text { Roger Christenson }\end{array}$ & $\begin{array}{l}\text { I } \\
\text { D }\end{array}$ & $\begin{array}{r}104.0 \\
60.0\end{array}$ & $\begin{array}{l}\text { do. } \\
\text { do. }\end{array}$ & $\begin{array}{l}\text { do. } \\
\text { ?t }\end{array}$ & $\begin{array}{l}12-04-85 \\
12-03-85\end{array}$ & $\begin{array}{l}1,443 \\
1,437\end{array}$ & $\begin{array}{l}19.7 \\
19.2\end{array}$ & $\begin{array}{l}1,423 \\
1,418\end{array}$ & $\begin{array}{l}\text { Yields } 1,200 \\
\text { QW; Yiel ds } 80 \\
\text { gal /m in }\end{array}$ \\
\hline $\begin{array}{l}25 s-03 w-30 B B A \\
25 s-03 w-34 A A A \\
25 s-03 w-36 B B B\end{array}$ & $\begin{array}{l}\text { Steve Beal } \\
\text { Tony and Ph1l Dozien } \\
\text { Joe Raple }\end{array}$ & $\begin{array}{l}\text { I } \\
\text { I } \\
\text { I }\end{array}$ & $\begin{array}{r}71.0 \\
126.0 \\
97.0\end{array}$ & $\begin{array}{l}\text { do. } \\
\text { do. } \\
\text { do. }\end{array}$ & $\begin{array}{l}\text { do. } \\
\text { Qt, QT } \\
\text { do. }\end{array}$ & $\begin{array}{l}12-04-85 \\
12-04-85 \\
12-04-85\end{array}$ & $\begin{array}{l}1,467 \\
1,415 \\
1,406\end{array}$ & $\begin{array}{l}41.3 \\
17.3 \\
12.8\end{array}$ & $\begin{array}{l}1,426 \\
1,398 \\
1,393\end{array}$ & $\begin{array}{l}\text { Y ields } 900 \mathrm{gal} / \mathrm{m} 1 \mathrm{n} \\
\text { Yields } 550 \mathrm{gal} / \mathrm{min} \\
\text { QW; yields } 1,200 \\
\text { gal /min }\end{array}$ \\
\hline $\begin{array}{l}26 S-02 E-10 A B A \\
26 S-02 E-29 A D A \\
26 S-02 E-35 A D A \\
26 S-02 E-36 D D A \\
26 S-01 E-07 C B C\end{array}$ & $\begin{array}{l}\text { R. A. Bagshaw } \\
\text { John Tolbert } \\
\text { Tommy Cagle } \\
\text { Lloyd Creed } \\
\text { Continental Pipel ine } \\
\text { Company }\end{array}$ & $\begin{array}{c}\text { L\&G } \\
L \& G \\
L \& G \\
D \\
D\end{array}$ & $\begin{array}{c}55.0 \\
80.0 \\
-- \\
45.0 \\
35.0\end{array}$ & $\begin{array}{l}\text { Shale } \\
\text { do. } \\
\text { do. } \\
\text { do. }\end{array}$ & $\begin{array}{l}\text { Pw } \\
\text { do. } \\
\text { do. } \\
\text { do. } \\
\text { Qal }\end{array}$ & $\begin{array}{l}12-06-85 \\
12-06-85 \\
12-06-85 \\
12-06-85 \\
12-06-85\end{array}$ & $\begin{array}{l}1,370 \\
1,420 \\
1,353 \\
1,340 \\
1,340\end{array}$ & $\begin{array}{l}22.1 \\
19.3 \\
19.0 \\
15.0 \\
18.4\end{array}$ & $\begin{array}{l}1,348 \\
1,401 \\
1,334 \\
1,325 \\
1,322\end{array}$ & QW \\
\hline $\begin{array}{l}26 S-01 E-11 D D B \\
26 S-01 E-17 C D A \\
26 S-01 E-18 C B D \\
26 S-01 E-19 A B D \\
26 S-01 E-20 B C C\end{array}$ & $\begin{array}{l}\text { Gene Wash 1ngton } \\
\text { Ted Hollis } \\
\text { Bob Burgan } \\
\text { Micheal Owens } \\
\text { Dr. J. C. Short }\end{array}$ & $\begin{array}{c}\text { L\&G } \\
\text { D } \\
\text { L\&G } \\
D \\
\text { L\&G }\end{array}$ & $\begin{array}{l}75.0 \\
40.0 \\
34.0 \\
25.0 \\
45.0\end{array}$ & $\begin{array}{l}\text { Sand, shale } \\
\text { Sand } \\
\text { do. } \\
\text { do. } \\
\text { do. }\end{array}$ & $\begin{array}{l}\text { Ql, Pw } \\
\text { Qal } \\
\text { do. } \\
\text { do. } \\
\text { do. }\end{array}$ & $\begin{array}{l}12-07-85 \\
12-07-85 \\
12-07-85 \\
12-07-85 \\
12-07-85\end{array}$ & $\begin{array}{l}1,393 \\
1,328 \\
1,333 \\
1,330 \\
1,330\end{array}$ & $\begin{array}{l}13.1 \\
12.4 \\
15.2 \\
13.4 \\
16.2\end{array}$ & $\begin{array}{l}1,380 \\
1,316 \\
1,318 \\
1,317 \\
1,314\end{array}$ & $\begin{array}{l}\text { Yields } 50 \mathrm{gal} / \mathrm{min} \\
\text { QW }\end{array}$ \\
\hline $\begin{array}{l}26 S-01 E-29 A B D \\
26 S-01 E-30 D D D \\
26 S-01 E-31 A D C \\
26 S-01 E-32 B D A \\
26 S-01 E-33 C C C\end{array}$ & $\begin{array}{l}\text { Junfor Pruitt } \\
\text { Tom Eddy } \\
\text { Joseph R. Blaha } \\
\text { Ke1th W1rths } \\
\text { KDHE }^{3}\end{array}$ & $\begin{array}{c}\text { L\&G } \\
L \& G \\
\text { L\&G } \\
\text { L\&G } \\
0\end{array}$ & $\begin{array}{l}40.0 \\
40.0 \\
40.0 \\
45.0 \\
17.0\end{array}$ & $\begin{array}{l}\text { do. } \\
\text { do. } \\
\text { do. } \\
\text { do. } \\
\text { do. }\end{array}$ & $\begin{array}{l}\text { do. } \\
\text { do. } \\
\text { do. } \\
\text { do. } \\
\text { do. }\end{array}$ & $\begin{array}{l}12-07-85 \\
12-08-85 \\
12-08-85 \\
12-08-85 \\
12-06-85\end{array}$ & $\begin{array}{l}1,321 \\
1,321 \\
1,320 \\
1,320 \\
1,315\end{array}$ & $\begin{array}{r}9.8 \\
12.5 \\
19.3 \\
14.1 \\
9.0\end{array}$ & $\begin{array}{l}1,311 \\
1,308 \\
1,301 \\
1,306 \\
1,306\end{array}$ & $\mathrm{QW}$ \\
\hline $\begin{array}{l}26 S-01 W-01 D B B \\
26 S-01 W-02 A B B \\
26 S-01 W-05 C A A \\
26 S-01 W-06 D D C \\
26 S-01 W-07 C B C\end{array}$ & $\begin{array}{l}\text { Gary Bolton } \\
\text { Charl es Frazee } \\
\text { Nolan Davis } \\
\text { Hugh Shaft } \\
\text { Dennis Meyer }\end{array}$ & $\begin{array}{c}\text { D } \\
\text { I } \\
0 \\
\text { S } \\
\text { L\&G }\end{array}$ & $\begin{array}{c}50.0 \\
64.0 \\
-- \\
40.0 \\
50.0\end{array}$ & $\begin{array}{c}\text { do. } \\
\text { do. } \\
\text { do. } \\
\text { do. } \\
\text { Sand, gravel }\end{array}$ & $\begin{array}{l}\text { do. } \\
\text { do. } \\
\text { do. } \\
\text { do. } \\
\text { do. }\end{array}$ & $\begin{array}{l}12-08-85 \\
12-06-85 \\
12-05-85 \\
12-05-85 \\
12-05-85\end{array}$ & $\begin{array}{l}1,345 \\
1,348 \\
1,357 \\
1,358 \\
1,360\end{array}$ & $\begin{array}{r}18.8 \\
10.2 \\
10.8 \\
5.7 \\
7.0\end{array}$ & $\begin{array}{l}1,326 \\
1,338 \\
1,346 \\
1,352 \\
1,353\end{array}$ & Yield $100 \mathrm{gal} / \mathrm{min}$ \\
\hline $\begin{array}{l}26 S-01 W-09 A A D \\
26 S-01 W-10 B C B \\
26 S-01 W-12 D C A \\
26 S-01 W-15 B C D \\
26 S-01 W-16 D D D\end{array}$ & $\begin{array}{l}\text { City of Wichita } \\
\text { do. } \\
\text { J.A. Wilson } \\
\text { George Nicholson } \\
\text { City of Wichita }\end{array}$ & $\begin{array}{c}0 \\
0 \\
\text { L\&G } \\
\text { L\&G } \\
0\end{array}$ & $\begin{array}{l}16.2 \\
15.3 \\
50.0 \\
90.0 \\
24.9\end{array}$ & $\begin{array}{c}\text { Sand } \\
\text { do. } \\
\text { do. } \\
\text { Sand, gravel } \\
\text { do. }\end{array}$ & $\begin{array}{l}\text { do. } \\
\text { do. } \\
\text { do. } \\
\text { Qa1, QT } \\
\text { Qa1 }\end{array}$ & $\begin{array}{l}12-05-85 \\
12-06-85 \\
12-06-85 \\
12-06-85 \\
01-01-86\end{array}$ & $\begin{array}{l}1,347 \\
1,348 \\
1,338 \\
1,345 \\
1,342\end{array}$ & $\begin{array}{r}6.9 \\
8.7 \\
15.0 \\
10.4 \\
5.9\end{array}$ & $\begin{array}{l}1,340 \\
1,339 \\
1,323 \\
1,335 \\
1,336\end{array}$ & $\begin{array}{l}\text { MW Wllson } \\
\text { MW York }\end{array}$ \\
\hline $\begin{array}{l}26 S-01 W-18 B C B \\
26 S-01 W-22 B A A \\
26 S-01 W-23 A A B \\
26 S-01 W-24 B B C \\
26 S-01 W-25 A B C\end{array}$ & $\begin{array}{l}\text { Leo R. Wetta } \\
\text { Sam Cox } \\
\text { C1ty of Wichita } \\
\text { do. } \\
\text { do. }\end{array}$ & $\begin{array}{c}D \\
\text { I.\&C } \\
0 \\
0 \\
0\end{array}$ & $\begin{array}{l}44.0 \\
30.0 \\
17.7 \\
19.7 \\
14.5\end{array}$ & $\begin{array}{l}\text { do. } \\
\text { Gravel } \\
\text { Sand do. } \\
\text { do. }\end{array}$ & $\begin{array}{l}\text { do. } \\
\text { do. } \\
\text { do. } \\
\text { do. } \\
\text { do. }\end{array}$ & $\begin{array}{l}12-05-85 \\
12-06-85 \\
12-05-85 \\
12-06-85 \\
12-05-85\end{array}$ & $\begin{array}{l}1,358 \\
1,340 \\
1,334 \\
1,332 \\
1,328\end{array}$ & $\begin{array}{r}8.4 \\
2.5 \\
9.7 \\
11.4 \\
10.0\end{array}$ & $\begin{array}{l}1,350 \\
1,337 \\
1,324 \\
1,321 \\
1,318\end{array}$ & $\begin{array}{l}\text { Ylelds } 50 \mathrm{gal} / \mathrm{m} 1 \mathrm{n} \\
\text { Y lelds } 60 \mathrm{gal} / \mathrm{m} 1 \mathrm{n} \\
\text { MW House } \\
\text { MW N. M dl es } \\
\text { MW Zl eschis }\end{array}$ \\
\hline $\begin{array}{l}26 \mathrm{~S}-01 \mathrm{~W}-27 \mathrm{AAB} \\
26 \mathrm{~S}-01 \mathrm{~W}-31 \mathrm{DAA} \\
26 \mathrm{~S}-01 \mathrm{~W}-36 \mathrm{ADA}\end{array}$ & $\begin{array}{l}\text { D1ck Helt } \\
\text { G. L. Manns } \\
\text { Will lam Reece }\end{array}$ & $\begin{array}{l}\text { L\&C, } \\
D \\
\text { L\&G }\end{array}$ & $\begin{array}{c}28.0 \\
60.0 \\
--\end{array}$ & $\begin{array}{l}\text { do. } \\
\text { do. } \\
\text { do. }\end{array}$ & $\begin{array}{l}\text { do. } \\
\text { ot } \\
\text { nal }\end{array}$ & $\begin{array}{l}12-05-85 \\
12-05-85 \\
12-08-85\end{array}$ & $\begin{array}{l}1,336 \\
1,352 \\
1,320\end{array}$ & $\begin{array}{r}9.4 \\
19.7 \\
12.1\end{array}$ & $\begin{array}{l}1,327 \\
1,332 \\
1,308\end{array}$ & $\begin{array}{l}\text { Y1elds } 85 \mathrm{gal} / \mathrm{m} 1 \mathrm{n} \\
\text { QW }\end{array}$ \\
\hline $26 \mathrm{~S}-02 \mathrm{~W}-04 \mathrm{DDA}$ & Tim Stolz & I & 92.0 & Sand, gravel & $\mathrm{Q}, \mathrm{QT}$ & $12-04-85$ & 1,395 & 30.1 & 1,365 & $\begin{array}{l}\text { Y 1elds } 1,000 \\
\text { gal /min }\end{array}$ \\
\hline $26 \mathrm{~S}-02 \mathrm{~W}-14 \mathrm{CAA}$ & $\begin{array}{l}\text { Kansas Gas and } \\
\text { E1 ectric Company }\end{array}$ & 0 & 185.0 & do. & do. & $12-04-85$ & 1,370 & 13.2 & 1,357 & \\
\hline
\end{tabular}


Table 14. Records of wells where water-level measurements were made during December 1985 and January 1986--Continued

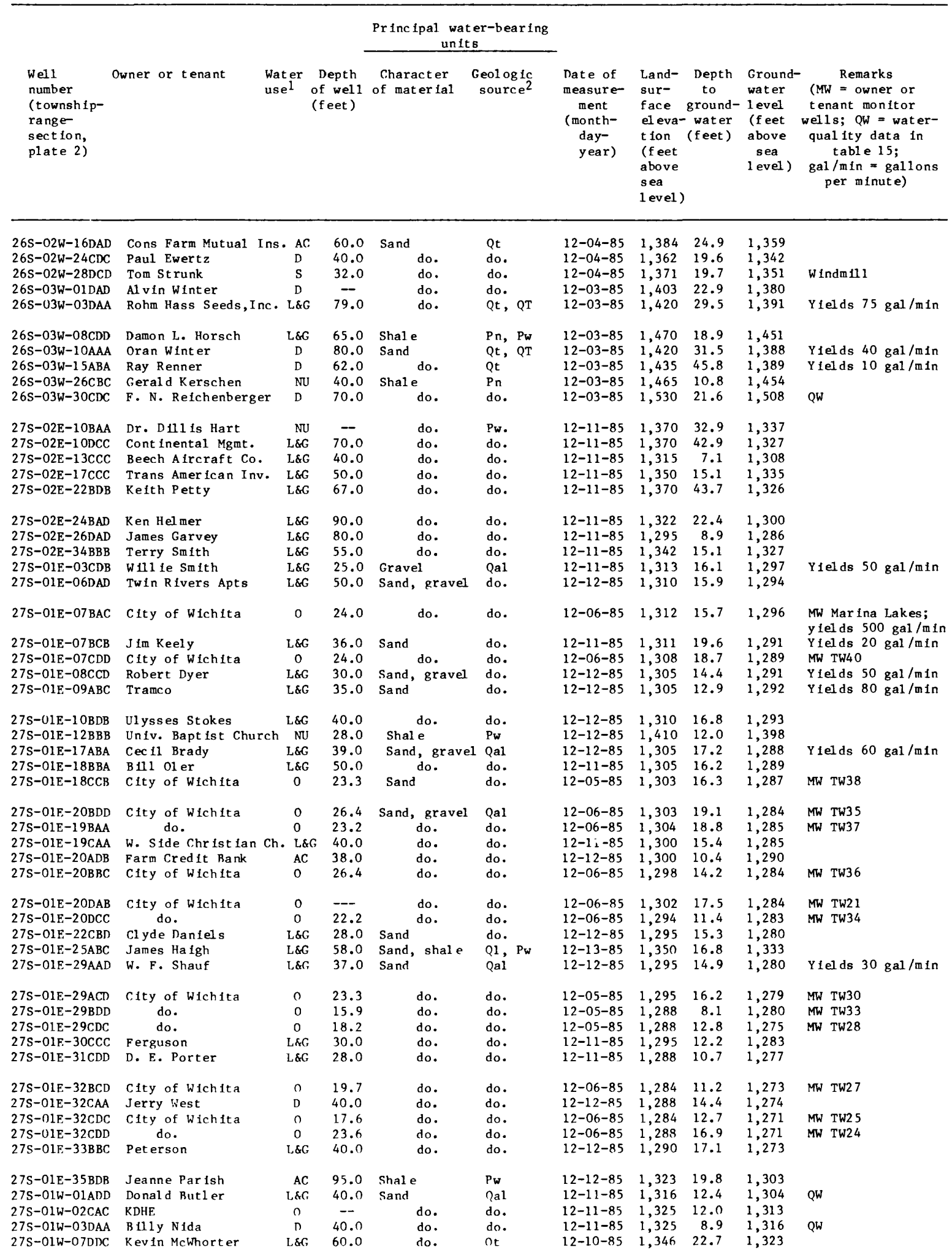


Table 14. Records of wells where water-level measurements were made during December 1985 and January 1986--Continued

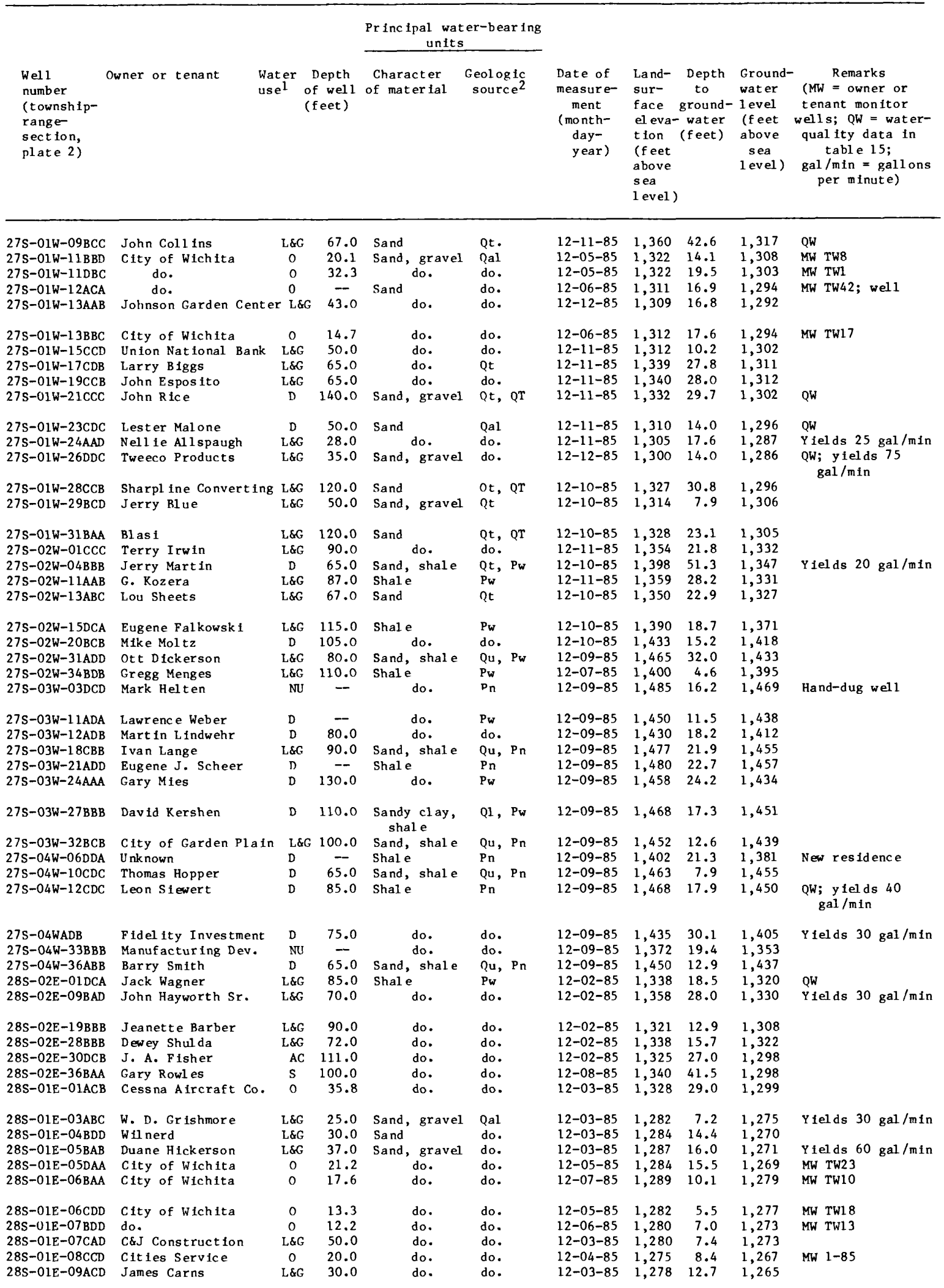


Table 14. Records of wells where water-level measurements were made during December 1985 and January 1986--Continued

\begin{tabular}{|c|c|c|c|c|c|c|c|c|c|c|}
\hline \multirow[b]{2}{*}{$\begin{array}{l}\text { Well } \\
\text { number } \\
\text { (township- } \\
\text { range- } \\
\text { section, } \\
\text { plate 2) }\end{array}$} & \multirow[b]{2}{*}{ Owner or tenant } & \multirow[b]{2}{*}{$\begin{array}{l}\text { Jater } \\
\text { ase }^{1}\end{array}$} & \multirow[b]{2}{*}{$\begin{array}{l}\text { Depth } \\
\text { of wel } 1 \\
\text { (f eet) }\end{array}$} & \multicolumn{2}{|c|}{$\begin{array}{c}\text { Principal water-bearing } \\
\text { units }\end{array}$} & \multirow[b]{2}{*}{$\begin{array}{l}\text { Date of } \\
\text { measure- } \\
\text { ment } \\
\text { (month- } \\
\text { day- } \\
\text { year) }\end{array}$} & \multirow[b]{2}{*}{$\begin{array}{l}\text { Land- } \\
\text { sur- } \\
\text { face } \\
\text { el eva- } \\
\text { t lon } \\
\text { (f eet } \\
\text { above } \\
\text { s ea } \\
\text { l evel) }\end{array}$} & \multirow[b]{2}{*}{$\begin{array}{l}\text { Depth } \\
\text { to } \\
\text { ground- } \\
\text { water } \\
\text { (f eet) } \\
\end{array}$} & \multirow[b]{2}{*}{$\begin{array}{l}\text { Ground- } \\
\text { water } \\
\text { l evel } \\
\text { (f eet } \\
\text { above } \\
\text { sea } \\
\text { l evel) }\end{array}$} & \multirow[b]{2}{*}{$\begin{array}{c}\text { Remarks } \\
\text { (MW = owner or } \\
\text { tenant monitor } \\
\text { wells; QW = water- } \\
\text { qual ity data in } \\
\text { tabl e } 15 ; \\
\text { gal } / \mathrm{m} \text { in }=\text { gallons } \\
\text { per minute) }\end{array}$} \\
\hline & & & & $\begin{array}{c}\text { Character } \\
\text { of material }\end{array}$ & $\begin{array}{l}\text { Geolog ic } \\
\text { source }\end{array}$ & & & & & \\
\hline $28 \mathrm{~S}-01 \mathrm{E}-10 \mathrm{CCC}$ & Landmark Drive In & L\&G & 40.0 & Sand, gravel & 1 Qal & $12-03-85$ & 1,273 & 8.2 & 1,265 & \\
\hline $28 \mathrm{~S}-01 \mathrm{E}-11 \mathrm{BCD}$ & V Ictor Gardner & L\&G & 40.0 & Sand, shale & $\mathrm{Qa1}, \mathrm{Pw}$ & $12-08-85$ & 1,312 & 22.6 & 1,289 & \\
\hline $28 \mathrm{~S}-01 \mathrm{E}-15 \mathrm{BBC}$ & Superfor Nursery & I & 35.0 & Sand & Qal & $12-04-85$ & 1,273 & 7.6 & 1,265 & \\
\hline $28 \mathrm{~S}-01 \mathrm{E}-16 \mathrm{DDA}$ & Vernon Richardson & L\&G & 40.0 & do. & do. & $12-04-85$ & 1,273 & 10.2 & 1,263 & \\
\hline $28 \mathrm{~S}-01 \mathrm{E}-17 \mathrm{CAC}$ & Don Pack & $\mathrm{L} \& \mathrm{G}$ & 28.0 & Sand & do. & $12-04-85$ & 1,276 & 10.5 & 1,266 & \\
\hline $28 \mathrm{~S}-01 \mathrm{E}-20 \mathrm{BCD}$ & $\mathrm{J}$ im Browser & L\&G & 30.0 & Sand, gravel & 1 do. & $12-05-85$ & 1,271 & 5.5 & 1,265 & Yiel ds $10 \mathrm{gal} / \mathrm{min}$ \\
\hline $28 S-01 E-21 A C C$ & $\mathrm{KDHE}^{3 /}$ & 0 & 26.5 & do. & do. & $12-04-85$ & 1,265 & 3.8 & 1,261 & MW 1 \\
\hline $28 \mathrm{~S}-01 \mathrm{E}-23 \mathrm{ABA}$ & Jess Matheny & L\&G & 82.0 & Sand, shale & $\mathrm{Qal}, \mathrm{Pw}$ & $12-07-85$ & 1,302 & 24.4 & 1,278 & \\
\hline $28 S-01 E-27 C B B$ & Lynn Harris & L\&G & 26.0 & Sand, gravel & $1 \quad$ Qal & $12-05-85$ & 1,265 & 14.5 & 1,251 & \\
\hline $28 \mathrm{~S}-01 \mathrm{E}-29 \mathrm{ACC}$ & $\mathrm{KDHE}^{3 /}$ & 0 & & do. & do. & $12-09-85$ & 1,267 & 10.7 & 1,256 & MW K4 \\
\hline $28 \mathrm{~S}-01 \mathrm{E}-31 \mathrm{CBC}$ & Randy Hall & L\&G & 65.0 & Sand & $Q t$ & $12-05-85$ & 1,290 & 36.8 & 1,253 & \\
\hline $28 \mathrm{~S}-01 \mathrm{E}-32 \mathrm{CAA}$ & $\mathrm{KDHE}^{3 /}$ & 0 & 48.0 & do. & Qal & $12-05-85$ & 1,262 & 11.1 & 1,251 & MW 7 \\
\hline $28 S-01 E-33 B D A$ & do. & 0 & 49.0 & do. & do. & $12-05-85$ & 1,267 & 17.0 & 1,250 & MW 11A \\
\hline $28 S-01 E-36 C C B$ & N1ck Belcher & L\&G & 65.0 & Sand, shale & $\mathrm{Qal}, \mathrm{Pw}$ & $12-02-85$ & 1,292 & 30.5 & 1,262 & \\
\hline $28 S-01 W-01 C D D$ & City of Wichita & 0 & 18.0 & Sand & Qal & $12-06-85$ & 1,288 & 8.8 & 1,279 & MW TW14 \\
\hline $28 S-01 W-02 D D C$ & do. & 0 & 25.9 & do. & do. & $12-05-85$ & 1,293 & 14.1 & 1,279 & MW TW16 \\
\hline $28 S-01 W-03 D C B$ & Cessna Aircraft Co. & $L \& G$ & 125.0 & do. & $Q t$ & $12-06-85$ & 1,305 & 20.6 & 1,284 & \\
\hline $28 \mathrm{~S}-01 \mathrm{~W}-09 \mathrm{AAA}$ & Wichita Pol ice Dept. & L\&G & 80.0 & do. & do. & $12-06-85$ & 1,314 & 27.4 & 1,287 & \\
\hline $28 \mathrm{~S}-01 \mathrm{~W}-10 \mathrm{CAC}$ & B 111 McCarthy & $L \& G$ & 60.0 & do. & do. & $12-06-85$ & 1,307 & 30.2 & 1,277 & \\
\hline $28 \mathrm{~S}-01 \mathrm{~W}-12 \mathrm{ABA}$ & Fonken & L\&G & 28.0 & Sand, gravel & $1 \quad$ Qal & $12-06-85$ & 1,287 & 9.8 & 1,277 & Yields $50 \mathrm{gal} / \mathrm{min}$ \\
\hline $28 \mathrm{~S}-01 \mathrm{~W}-17 \mathrm{AAD}$ & Ed B irdwel1 & L\&G & 95.0 & do. & Qt & $12-06-85$ & 1,315 & 42.4 & 1,273 & Ylelds $80 \mathrm{gal} / \mathrm{min}$ \\
\hline $\begin{array}{l}28 \mathrm{~S}-01 \mathrm{~W}-19 \mathrm{ADA} \\
28 \mathrm{~S}-01 \mathrm{~W}-21 \mathrm{CDB}\end{array}$ & $\begin{array}{l}\text { Emmett S imon } \\
\text { Roman Thome }\end{array}$ & $\begin{array}{c}I \\
L \& G\end{array}$ & $\begin{array}{r}104.0 \\
80.0\end{array}$ & $\begin{array}{l}\text { Sand } \\
\text { do. }\end{array}$ & $\begin{array}{l}\text { do. } \\
\text { do. }\end{array}$ & $\begin{array}{l}12-06-85 \\
12-06-85\end{array}$ & $\begin{array}{l}1,322 \\
1,315\end{array}$ & $\begin{array}{l}30.3 \\
46.9\end{array}$ & $\begin{array}{l}1,292 \\
1,268\end{array}$ & Y ields $700 \mathrm{gal} / \mathrm{min}$ \\
\hline $28 \mathrm{~S}-01 \mathrm{~W}-23 \mathrm{CCB}$ & Vulcan Materials & 0 & 35.0 & Sand, gravel & do. & $12-03-85$ & 1,291 & $\begin{array}{l}40.9 \\
24.4\end{array}$ & $\begin{array}{l}1,200 \\
1,267\end{array}$ & MW $11 \mathrm{~S}-\mathrm{AD}$ \\
\hline $28 \mathrm{~S}-01 \mathrm{~W}-23 \mathrm{DCD}$ & do. & 0 & 61.0 & do. & do. & $12-07-85$ & 1,288 & 23.7 & 1,264 & MW $4 S-A D$ \\
\hline $28 \mathrm{~S}-01 \mathrm{~W}-24 \mathrm{BBA}$ & James Wilson & D & 57.0 & Sand & Qal & $12-06-85$ & 1,278 & 10.5 & 1,268 & QW \\
\hline $28 S-01 W-26 B B C$ & St even Peterson & L\&G & 60.0 & do. & Qt & $12-07-85$ & 1,300 & 37.2 & 1,263 & \\
\hline $28 \mathrm{~S}-01 \mathrm{~W}-27 \mathrm{DAA}$ & Vulcan Mater 1als & 0 & 57.5 & Sand, gravel & 1 do. & $12-04-85$ & 1,300 & 35.7 & 1,264 & MW $10 S-A D$ \\
\hline $28 \mathrm{~S}-01 \mathrm{~W}-28 \mathrm{ABA}$ & Tom Bergkamp & I & 127.0 & do. & do. & $12-06-85$ & 1,309 & 42.4 & 1,267 & \\
\hline $28 \mathrm{~S}-01 \mathrm{~W}-33 \mathrm{ADA}$ & Vulcan Materials & 0 & 82.0 & do. & $Q t$ & $12-04-85$ & 1,306 & 48.5 & 1,258 & MW $9 S-A D$ \\
\hline $28 \mathrm{~S}-01 \mathrm{~W}-34 \mathrm{AAD}$ & do. & 0 & 51.0 & do. & do. & $12-03-85$ & 1,301 & 42.1 & 1,259 & MW $13 \mathrm{~S}-\mathrm{AD}$ \\
\hline $28 S-02 W-03 B C C$ & Ron Nelson & D & 36.0 & Sand & Qu & $12-07-85$ & 1,428 & 30.1 & 1,398 & Yields $30 \mathrm{gal} / \mathrm{min}$ \\
\hline $28 \mathrm{~S}-02 \mathrm{~W}-07 \mathrm{CCB}$ & Jim Cooper & D & 130.0 & Sand, shale & $Q_{u}, P_{w}$ & $12-07-85$ & 1,420 & 14.1 & 1,406 & \\
\hline $28 \mathrm{~S}-02 \mathrm{~W}-11 \mathrm{DCC}$ & Ed 0sterman & D & 95.0 & do. & $01, P_{w}$ & $12-08-85$ & 1,370 & 33.7 & 1,336 & \\
\hline $28 \mathrm{~S}-02 \mathrm{~W}-17 \mathrm{BDA}$ & Craig Page & $D$ & 60.0 & do. & $Q u, P w$ & $12-07-85$ & 1,420 & 6.7 & 1,413 & Y1elds $30 \mathrm{gal} / \mathrm{m} 1 \mathrm{n}$ \\
\hline $28 \mathrm{~S}-02 \mathrm{~W}-19 \mathrm{DDC}$ & John Wells & $\mathrm{s}$ & 40.0 & Sand & Ou & $12-07-85$ & 1,405 & 10.1 & 1,395 & \\
\hline $28 \mathrm{~S}-02 \mathrm{~W}-22 \mathrm{CDB}$ & Leroy Webber & L\&G & 50.0 & do. & do. & $12-07-85$ & 1,385 & 12.0 & 1,373 & Yiel ds $11 \mathrm{gal} / \mathrm{min}$ \\
\hline $28 \mathrm{~S}-02 \mathrm{~W}-25 \mathrm{AAD}$ & Roman $\mathrm{K} 1$ ausmeyer & I & 138.0 & Sand, gravel & $1 \mathrm{Qt}, \mathrm{OT}$ & $12-07-85$ & 1,343 & 31.2 & 1,312 & \\
\hline $28 \mathrm{~S}-02 \mathrm{~W}-32 \mathrm{AAA}$ & B1ll Gorges & L\&G & 95.0 & Shal e & $\mathrm{Pw}$ & $12-07-85$ & 1,398 & 17.4 & 1,381 & QW; $\underset{\mathrm{gal} / \mathrm{min}}{\mathrm{y} \text { in ds }} 20$ \\
\hline $28 \mathrm{~S}-03 \mathrm{~W}-10 \mathrm{DAD}$ & Lake Afton Observ. & $\mathbf{P}$ & 90.0 & Sand, shale & $\mathrm{Qu}, \mathrm{Pw}_{\mathbf{w}}$ & $12-09-85$ & 1,393 & 12.6 & 1,380 & \\
\hline $28 \mathrm{~S}-03 \mathrm{~W}-12 \mathrm{AAA}$ & Rebecca Cunningham & D & 50.0 & Sand, gravel & $1 \quad \mathrm{Qu}$ & $12-09-85$ & 1,432 & 9.1 & 1,423 & \\
\hline $28 \mathrm{~S}-03 \mathrm{~W}-14 \mathrm{BAD}$ & Camp Fell owship & $D$ & 110.0 & Shal e & Pw & & 1,390 & 8.5 & 1,382 & \\
\hline $28 \mathrm{~S}-03 \mathrm{~W}-18 \mathrm{CBC}$ & Norbert Berkamp & $\mathrm{s}$ & 128.0 & do. & $\mathrm{Pn}, \mathrm{Pw}_{\mathrm{w}}$ & $12-09-85$ & 1,382 & 34.7 & 1,347 & Y1el ds $11 \mathrm{gal} / \mathrm{m}$ in \\
\hline $28 \mathrm{~S}-03 \mathrm{~W}-2100 \mathrm{D}$ & Chris Mountain & D & 110.0 & do. & do. & $12-09-85$ & 1,365 & 10.3 & 1,355 & \\
\hline $28 \mathrm{~S}-03 \mathrm{~W}-23 \mathrm{ACA}$ & Tipton & L\&G & 125.0 & Sand, shale & $\mathrm{Qu}, \mathrm{Pw}_{\mathrm{w}}$ & $12-09-85$ & 1,395 & 16.0 & 1,379 & \\
\hline $28 \mathrm{~S}-04 \mathrm{~W}-05 \mathrm{CDC}$ & Unif led Sch. Dist.2 & L\&G & 88.0 & Shale & $\mathrm{Pn}$ & $12-09-85$ & 1,385 & 15.0 & 1,370 & \\
\hline $28 \mathrm{~S}-04 \mathrm{~W}-08 \mathrm{BDD}$ & Todd Rosenhagen & $L \& G$ & 74.0 & Sand, shale & $\mathrm{Qc}, \mathrm{Pn}$ & $12-09-85$ & 1,385 & 14.7 & 1,370 & \\
\hline $28 \mathrm{~S}-04 \mathrm{~W}-09 \mathrm{ADB}$ & City of Cheney & 0 & 20.0 & do. & do. & $12-10-85$ & 1,344 & 6.0 & 1,338 & \\
\hline $28 \mathrm{~S}-04 \mathrm{~W}-15 \mathrm{BCB}$ & C. W. Sebits & D & 50.0 & Shale & $\mathrm{Pn}$ & $12-10-85$ & 1,345 & 10.7 & 1,334 & $\mathrm{OW}$ \\
\hline $28 \mathrm{~S}-04 \mathrm{~W}-20 \mathrm{ABA}$ & R. L. Bl akely & D & 74.0 & Sand, shale & Qal, Pn & $02-27-86$ & 1,340 & 7.9 & 1,332 & $Q W$ \\
\hline $28 \mathrm{~S}-04 \mathrm{~W}-20 \mathrm{ABD}$ & R. L. Blakely & $\mathrm{D}$ & 65.0 & do. & do. & $02-27-86$ & 1,337 & 4.0 & 1,333 & QW \\
\hline $29 \mathrm{~S}-02 \mathrm{E}-04 \mathrm{AAD}$ & Elwood Jones & $\mathrm{D}$ & 84.0 & Shal e & $\mathrm{Pw}_{\mathrm{w}}$ & $12-10-85$ & 1,308 & 41.1 & 1,267 & \\
\hline $29 S-02 E-18 A D D$ & George Wayman & D & 90.0 & do. & do. & $12-09-85$ & 1,310 & 53.2 & 1,257 & \\
\hline $29 \mathrm{~S}-02 \mathrm{E}-18 \mathrm{CBC}$ & Harold Matheny & D & 80.0 & Sand, shale & $Q_{t}, P_{w}$ & $12-09-85$ & 1,280 & 43.9 & 1,236 & ield? \\
\hline $29 \mathrm{~S}-02 \mathrm{E}-19 \mathrm{CCD}$ & Meyers Nut Farm & $\mathrm{s}$ & - & Shal e & & $12-10-85$ & 1,263 & 38.5 & 1,225 & Good yield? \\
\hline
\end{tabular}


Table 14. Records of wells where water-level measurements were made during December 1985 and January 1986--Continued

\begin{tabular}{|c|c|c|c|c|c|c|c|c|c|c|}
\hline \multirow[b]{2}{*}{$\begin{array}{l}\text { Well } \\
\text { number } \\
\text { (township- } \\
\text { range- } \\
\text { section, } \\
\text { plate 2) }\end{array}$} & \multirow[b]{2}{*}{ Owner or tenant } & \multirow[b]{2}{*}{$\mathrm{e}^{1}$} & \multirow[b]{2}{*}{$\begin{array}{l}\text { Depth } \\
\text { of wel } 1 \\
\text { (f eet) }\end{array}$} & \multicolumn{2}{|c|}{$\begin{array}{c}\text { Principal wat er-bearing } \\
\text { units }\end{array}$} & \multirow[b]{2}{*}{$\begin{array}{l}\text { Date of } \\
\text { measure- } \\
\text { ment } \\
\text { (month- } \\
\text { day- } \\
\text { year) }\end{array}$} & \multirow[b]{2}{*}{$\begin{array}{l}\text { Land- } \\
\text { sur- } \\
\text { face } \\
\text { el eva- } \\
\text { t ion } \\
\text { (f eet } \\
\text { above } \\
\text { sea } \\
\text { l evel) }\end{array}$} & \multirow[b]{2}{*}{$\begin{array}{l}\text { Depth } \\
\text { to } \\
\text { ground- } \\
- \text { water } \\
\text { (f eet) } \\
\\
\text { ) }\end{array}$} & \multirow[b]{2}{*}{$\begin{array}{l}\text { Ground- } \\
\text { water } \\
1 \text { evel } \\
\text { (f eet } \\
\text { above } \\
\text { sea } \\
1 \text { evel) }\end{array}$} & \multirow[b]{2}{*}{$\begin{array}{c}\text { Remarks } \\
\text { (MW = owner or } \\
\text { tenant monitor } \\
\text { wel1s; QW = water- } \\
\text { qual ity data in } \\
\text { tabl e } 15 \text {; } \\
\text { gal /min = gallons } \\
\text { per minute) }\end{array}$} \\
\hline & & & & $\begin{array}{l}\text { Character } \\
\text { of material }\end{array}$ & $\begin{array}{l}\text { Geolog } 1 \mathrm{c} \\
\text { source }\end{array}$ & & & & & \\
\hline $29 \mathrm{~S}-02 \mathrm{E}-22 \mathrm{BCB}$ & 3 Unknown & -- & - & Shale & $P_{w}$ & $12-10-85$ & 1,315 & 29.2 & 1,286 & \\
\hline $29 \mathrm{~S}-02 \mathrm{E}-23 \mathrm{ABA}$ & Howard Humbol dt & $\mathrm{s}$ & -- & do. & do. & $12-10-85$ & 1,318 & 39.1 & 1,279 & \\
\hline $29 \mathrm{~S}-02 \mathrm{E}-25 \mathrm{BCC}$ & B 111 Reager & D & 78.0 & do. & do. & $12-10-85$ & 1,330 & 49.4 & 1,281 & Yields $20 \mathrm{gal} / \mathrm{min}$ \\
\hline $29 \mathrm{~S}-02 \mathrm{E}-27 \mathrm{BBB}$ & Wright & -- & -- & do. & do. & $12-10-85$ & 1,300 & 31.8 & 1,268 & \\
\hline $29 \mathrm{~S}-02 \mathrm{E}-31 \mathrm{DDD}$ & Roy Dud1 ey & $L \& G$ & 35.0 & Sand & Qa1 & $12-10-85$ & 1,250 & 14.6 & 1,235 & Yields $50 \mathrm{gal} / \mathrm{min}$ \\
\hline $29 \mathrm{~S}-02 \mathrm{E}-32 \mathrm{BAB}$ & Jack Farber & -- & -- & Shal e & $\mathrm{Pw}$ & $12-10-85$ & 1,281 & 38.9 & 1,242 & \\
\hline $29 \mathrm{~S}-01 \mathrm{E}-01 \mathrm{BDC}$ & $\begin{array}{l}\text { Happy P1 ant-Garden } \\
\text { Center }\end{array}$ & $L \& G$ & 60.0 & Sand, shale & $\mathrm{Q} 1, \mathrm{P}_{\mathrm{w}}$ & $12-09-85$ & 1,295 & 40.1 & 1,255 & \\
\hline $29 S-01 E-01 D D A$ & Kermit McGreger & $L \& G$ & 60.0 & do. & do. & $12-09-85$ & 1,295 & 26.4 & 1,269 & \\
\hline $29 \mathrm{~S}-01 \mathrm{E}-02 \mathrm{BBD}$ & N. S. Cornel son & -- & - & Sand, gravel & Qal & $12-08-85$ & 1,255 & 10.2 & 1,245 & \\
\hline $29 \mathrm{~S}-01 \mathrm{E}-03 \mathrm{AAD}$ & $\mathrm{KDHE}^{3}$ & 0 & 22.5 & do. & do. & $12-08-85$ & 1,250 & 8.0 & 1,242 & \\
\hline $29 \mathrm{~S}-01 \mathrm{E}-04 \mathrm{ABB}$ & Valgene Smith & $L \& G$ & 30.0 & Sand & Qa1 & $12-07-85$ & 1,259 & 13.1 & 1,246 & \\
\hline $29 \mathrm{~S}-01 \mathrm{E}-05 \mathrm{BBA}$ & Haysville State Bank & L\&G & 35.0 & do. & do. & $12-07-85$ & 1,260 & 13.4 & 1,247 & Yields $60 \mathrm{gal} / \mathrm{min}$ \\
\hline $29 S-01 E-07 B A B$ & Vivian Howell & D & 59.0 & Sand, gravel & $\mathrm{Qt}$ & $12-06-85$ & 1,290 & 37.1 & 1,253 & \\
\hline 29S-01E-09DAC & Unknown & NU & -- & do. & Oal & $12-07-85$ & 1,250 & 7.1 & 1,243 & \\
\hline 29S-01E-1ODDD & Linden Benson & L\&G & 40.0 & do. & do. & $12-08-85$ & 1,247 & 11.0 & 1,236 & \\
\hline $29 \mathrm{~S}-01 \mathrm{E}-11 \mathrm{ABC}$ & Bob Smith & L\&G & -- & Sand & do. & $12-08-85$ & 1,250 & 12.0 & 1,238 & \\
\hline $29 \mathrm{~S}-01 \mathrm{E}-12 \mathrm{AAC}$ & Mark E1l is & $L \& G$ & -- & Shal e & $P_{\mathbf{w}}$ & $12-09-85$ & 1,275 & 15.3 & 1,260 & \\
\hline $29 \mathrm{~S}-01 \mathrm{E}-13 \mathrm{DBC}$ & $\begin{array}{l}\text { Derby Wast ewater } \\
\text { Treatment Fac } 11 \text { ity }\end{array}$ & NU & -- & Sand, gravel & Qa1 & $12-09-85$ & 1,250 & 14.8 & 1,235 & \\
\hline $29 \mathrm{~S}-01 \mathrm{E}-14 \mathrm{CDA}$ & Lill Ian Harmon & $\mathrm{D}$ & -- & do. & do. & $12-07-85$ & 1,240 & 12.4 & 1,228 & \\
\hline $29 \mathrm{~S}-01 \mathrm{E}-16 \mathrm{DBA}$ & P. V. Brooks & LEG & -- & do. & do. & $12-07-85$ & 1,245 & 8.1 & 1,237 & \\
\hline $29 \mathrm{~S}-01 \mathrm{E}-17 \mathrm{ADD}$ & Jack Henry & -- & - & Sand & do. & $12-06-85$ & 1,245 & 8.8 & 1,236 & \\
\hline $29 \mathrm{~S}-01 \mathrm{E}-21 \mathrm{BBC}$ & James 01 iphant & L\&G & 40.0 & do. & do. & $12-07-85$ & 1,244 & 8.1 & 1,236 & \\
\hline $29 \mathrm{~S}-01 \mathrm{E}-23 \mathrm{BBB}$ & Ed Bachman & I & 50.0 & do. & do. & $12-08-85$ & 1,242 & 11.2 & 1,231 & \\
\hline $29 \mathrm{~S}-01 \mathrm{E}-2 \mathrm{5DCC}$ & Larry W. Bryan & $\mathrm{D}$ & 30.0 & do. & do. & $12-09-85$ & 1,229 & 7.1 & 1,222 & \\
\hline $29 \mathrm{~S}-01 \mathrm{E}-26 \mathrm{DAA}$ & Ol iver Laurie & $\mathbf{I}$ & 45.0 & do. & do. & $12-08-85$ & 1,233 & 12.1 & 1,221 & \\
\hline $29 \mathrm{~S}-01 \mathrm{E}-27 \mathrm{AAA}$ & John Robertson & $L \& G$ & -- & Sand, gravel & do. & $12-07-85$ & 1,235 & 9.0 & 1,226 & \\
\hline $29 S-01 E-29 C B D$ & Charles Ott & I & 51.0 & do. & $0 t$ & $12-07-85$ & 1,270 & 27.5 & 1,242 & Yields $900 \mathrm{gal} / \mathrm{min}$ \\
\hline $29 \mathrm{~S}-01 \mathrm{E}-32 \mathrm{CBC}$ & Hefl berg & I & -- & do. & do. & $12-07-85$ & 1,266 & 30.0 & 1,236 & \\
\hline $29 S-01 E-34 D A D$ & Juanita Bradford & -- & -- & do. & Qal & $12-07-85$ & 1,230 & 11.0 & 1,219 & \\
\hline $29 S-01 E-35 B B B$ & Gal en Ger1 ach & $\mathrm{D}$ & 50.0 & Sand & do. & $12-08-85$ & 1,232 & 10.7 & 1,221 & Yields $800 \mathrm{gal} / \mathrm{min}$ \\
\hline $29 \mathrm{~S}-01 \mathrm{~F}-36 \mathrm{CBC}$ & Melvin Lentz & $D$ & 54.0 & do. & do. & $12-09-85$ & 1,225 & 8.2 & 1,217 & $\begin{array}{c}\text { Y1elds } 1,150 \\
\text { gal /min }\end{array}$ \\
\hline $29 \mathrm{~S}-01 \mathrm{~W}-03 \mathrm{DBA}$ & M. W. Br\|l ey & $\mathrm{D}$ & 60.0 & do. & Qt & $12-05-85$ & 1,291 & 35.1 & 1,256 & \\
\hline $29 \mathrm{~S}-0 I \mathrm{~W}-06 \mathrm{DBB}$ & L. E. Soupene & $\mathrm{D}$ & 33.0 & Sand, gravel & do. & $12-05-85$ & 1,320 & 12.3 & 1,308 & \\
\hline $29 \mathrm{~S}-01 \mathrm{~W}-08 \mathrm{BAA}$ & Al ma Mae Hasl er & - & - & Sand & do. & $12-05-85$ & 1,295 & 14.5 & 1,280 & \\
\hline $29 \mathrm{~S}-01 \mathrm{~W}-11 \mathrm{ADD}$ & Angie Hutchinson & $\mathrm{D}$ & 65.0 & do. & do. & $12-06-85$ & 1,287 & 32.4 & 1,255 & QW \\
\hline $29 \mathrm{~S}-01 \mathrm{w}-20 \mathrm{CCD}$ & J. Bruce Learmont & -- & -- & Sand, gravel & do. & $12-05-85$ & 1,270 & 14.9 & 1,255 & \\
\hline $29 \mathrm{~S}-01 \mathrm{~W}-24 \mathrm{ACA}$ & Gressell Corporation & NU & 60.0 & do. & do. & $12-05-85$ & 1,275 & 33.8 & 1,241 & \\
\hline $29 \mathrm{~S}-01 \mathrm{~W}-25 \mathrm{BBB}$ & Tony Lies & I & 66.0 & do. & do. & $12-06-85$ & 1,276 & 35.2 & 1,241 & \\
\hline $29 \mathrm{~S}-01 \mathrm{~W}-27 \mathrm{BBB}$ & Gl enn Luckner & L\&G, & 44.0 & Sand & do. & $12-06-85$ & 1,258 & 9.8 & 1,248 & QW \\
\hline $29 \mathrm{~S}-01 \mathrm{w}-34 \mathrm{CDD}$ & Leonard Schmeissner & $\mathrm{D}$ & 45.0 & do. & do. & $12-06-85$ & 1,248 & 11.0 & 1,237 & \\
\hline $29 \mathrm{~S}-01 \mathrm{~W}-36 \mathrm{DDD}$ & Ira Dietrich & $\mathrm{D}$ & 60.0 & do. & do. & $12-05-85$ & 1,252 & 21.0 & 1,231 & \\
\hline $29 \mathrm{~S}-02 \mathrm{~W}-03 \mathrm{BBB}$ & Herman Seiter & $\mathrm{D}$ & 60.0 & Sand, shale & Qu, $P_{w}$ & $12-04-85$ & 1,386 & 18.8 & 1,367 & Y 1el ds $35 \mathrm{gal} / \mathrm{m}$ in \\
\hline $29 \mathrm{~S}-02 \mathrm{~W}-16 \mathrm{ABC}$ & Cecil Pletz & $\mathrm{NU}$ & -- & Shal e & $\mathrm{P}_{\mathrm{w}}$ & $12-04-85$ & 1,310 & 9.7 & 1,300 & \\
\hline $29 \mathrm{~S}-02 \mathrm{~W}-17 \mathrm{CBB}$ & Del bert Towns end & $\mathrm{D}$ & 44.0 & Sand, shale & $O c, P_{w}$ & $12-04-85$ & 1,308 & 18.0 & 1,290 & \\
\hline $29 S-02 W-19 D B B$ & Vulcan Materials & 0 & 34.0 & Sand, gravel & २a1 & $12-05-85$ & 1,280 & 9.6 & 1,273 & \\
\hline $29 \mathrm{~S}-02 \mathrm{~W}-20 \mathrm{DDA}$ & Vulcan Materials & 0 & 38.0 & do. & do. & $12-05-85$ & 1,266 & 3.5 & 1,262 & \\
\hline $29 \mathrm{~S}-02 \mathrm{~W}-24 \mathrm{CBC}$ & B 111 Machart & L\&G. & 66.0 & Sand & $Q t$ & $12-05-85$ & 1,290 & 26.2 & 1,264 & \\
\hline $29 \mathrm{~S}-02 \mathrm{~W}-26 \mathrm{ABB}$ & Lou is e $W$ is e & $L \& G$ & 52.0 & do. & Qal & $12-04-85$ & 1,285 & 23.8 & 1,261 & \\
\hline $29 \mathrm{~S}-02 \mathrm{~W}-30 \mathrm{ABC}$ & Vulcan Materials & 0 & 38.0 & Sand, gravel & do. & $12-05-85$ & 1,273 & 5.1 & 1,268 & \\
\hline $29 \mathrm{~S}-02 \mathrm{~W}-30 \mathrm{ADD}$ & Doana Parsons & $\mathrm{s}$ & -- & Shale & $\mathrm{Pw}$ & $12-04-85$ & 1,300 & 25.0 & 1,275 & \\
\hline $29 \mathrm{~S}-02 \mathrm{~W}-35 \mathrm{BCC}$ & Delbert McMillian & -- & -- & Sand & oa1 & $12-04-85$ & 1.260 & 11.6 & 1,248 & \\
\hline $29 \mathrm{~S}-03 \mathrm{~W}-09 \mathrm{ABA}$ & Roy Holder & L\&G & 45.0 & do. & do. & $12-03-85$ & 1,297 & 2.8 & 1,294 & nw \\
\hline $29 \mathrm{~S}-03 \mathrm{~W}-14 \mathrm{CCD}$ & Fl a ine Nighswanger & s & 45.0 & do. & do. & $12-04-85$ & 1,290 & 5.3 & 1,285 & \\
\hline $29 \mathrm{~S}-03 \mathrm{~W}-21 \mathrm{DDA}$ & Gary Porter & L\&G & -- & Shale & $\mathrm{Pn}$ & $12-07-85$ & 1,317 & 8.3 & 1,309 & \\
\hline $29 \mathrm{~S}-03 \mathrm{~W}-23 \mathrm{ABB}$ & Roger Lemon & - & -- & Sand & Qa1 & $12-04-85$ & 1,286 & 11.0 & 1,275 & \\
\hline
\end{tabular}


Table 14. Records of wells where water-level measurements were made during December 1985 and January 1986--Continued

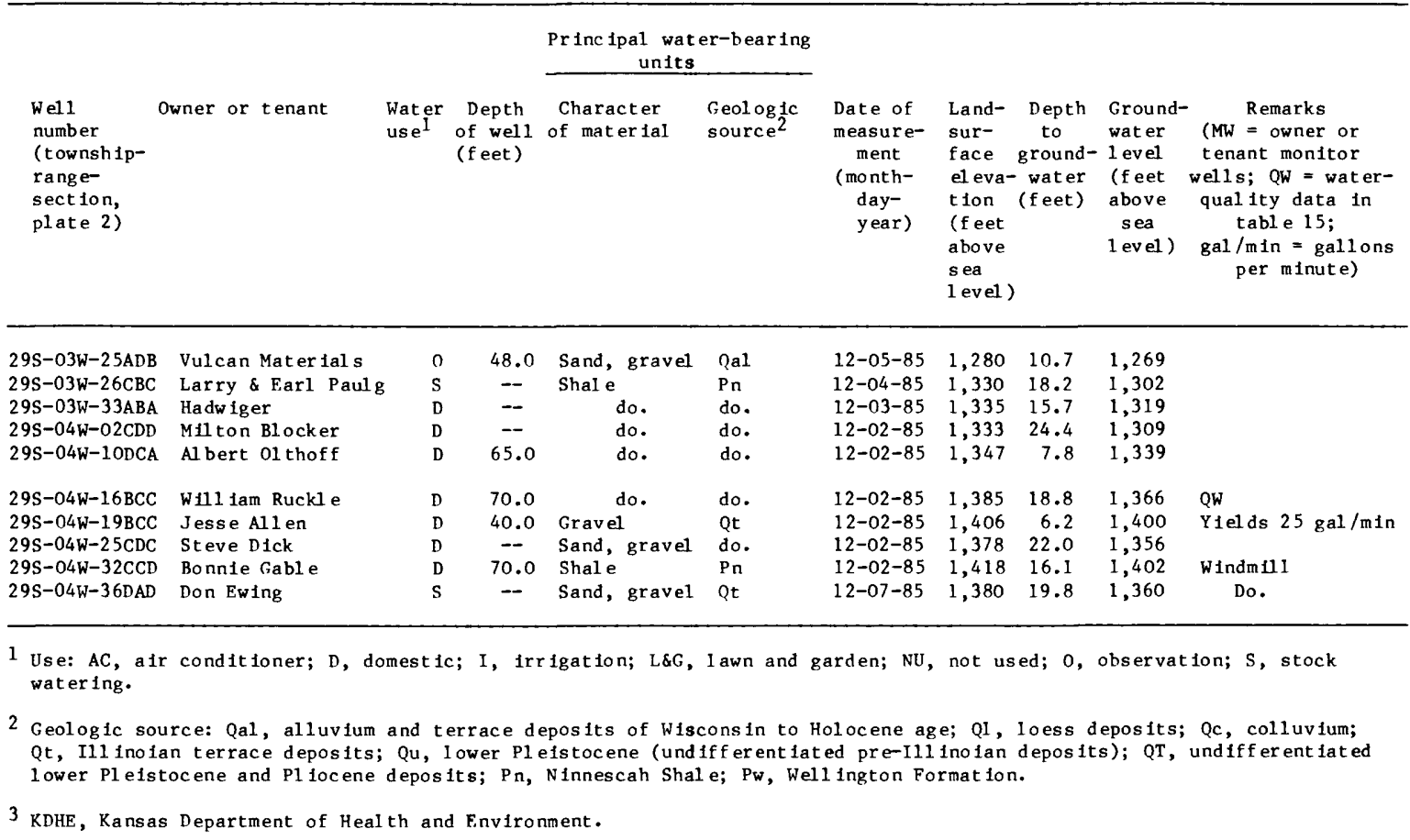

Ground-water-level contours are dashed on plate 2 in areas where either the saturated thickness of unconsolidated deposits is less than 20 feet or where the ground-water elevation is below the bedrock surface. Although shale bedrock that occurs near or at the surface in the eastern part of the county as the Wellington Formation and in the western part of the county as the Ninnescah Shale is not a good aquifer because the fine-grained consolidated rock does not readily transmit water, the bedrock generally is saturated below the ground-waterlevel contours that are shown. Contours are omitted in areas where water-level measurements were not available, such as in the extreme northeast part of the county.

Unconfined ground water flows from higher to lower elevations in the direction that is perpendicular to the ground-water-level contours. The water-level contours generally mirror the surface topographic contours but are more subdued. In upland areas between the Arkansas and Ninnescah Rivers and east of the Little Arkansas River and the Arkansas River south of Wichita, the ground-water divides correspond to the topographic divides and are equivalent to surface-drainage divides between the Ninnescah and Arkansas Rivers and between streams that flow west toward the Little Arkansas and Arkansas Rivers and streams that flow east to the Walnut River in Butler County.

In the North Fork Ninnescah, South Fork Ninnescah, Ninnescah, and Little Arkansas River valleys, ground water flows primarily toward the streams, indicating that these are gaining streams. In the Arkansas River valley, ground water flows primarily down the valley parallel to the stream. Where the water-level contours cross the Arkansas River north of Wichita, they have relatively small random inflections, indicating the stream is approximately in equilibrium with the ground water and is neither gaining nor losing. From Wichita south to the Sumner County line, the water-level contours are inflected in an upstream direction as they cross the Arkansas River, indicating that the stream is gaining water through this reach.

At several locations in the county, the inflection of water-level contours indicates cones of depression caused by ground-water 
withdrawals for industrial and public supplies. The wells were measured in December and January, and the effects of withdrawals for irrigation are not evident. Withdrawals for public supplies from the Wichita well field have created the largest cone of depression, as evidenced by large inflections of water-level contours in the northern one-half of township 25 south, range 2 west and in the northwest quarter of range 1 west. Slight cones of depression from withdrawals for public supplies appear to be present just east of Mount Hope, in the vicinity of Valley Center on the east side of the Little Arkansas River, about 1 mile southwest of Maize, and west of Derby on the west side of the Arkansas River. Withdrawals for public supplies and self-supplied industrial use appear to have caused cones of depression on the east side of the Little Arkansas River about 4 miles southwest of Kechi, and in the southeast part of Haysville. Withdrawals by industry appear to have caused cones of depression northwest of Colwich, between the Arkansas and Little Arkansas Rivers about 4 miles upstream of their confluence with the Arkansas River to about 3 miles upstream, on the east side of the Arkansas River about 2 miles southeast of its confluence with the Little Arkansas River, about 3 miles west of Haysville, about 3 miles south of the Wichita airport, and in the vicinity of the Wichita airport. Most of the cones of depression are not well defined because the spacing between measured wells is too great.

In contrast to the cones of depression caused by ground-water withdrawals, a low-head dam on the Little Arkansas River just upstream from its confluence with the Arkansas River appears to have caused the formation of a mound of ground water under the Little Arkansas River.

\section{Historic Fluctuations in Water Levels}

Water-level measurements have been made at monitoring wells in Sedgwick County on a regular basis since 1938 . These long-term monitoring wells were established to observe effects of the Wichita well field on ground-water levels in alluvium and terrace deposits of the Arkansas and Little Arkansas Rivers in northern Sedgwick County. However, a few monitoring wells were established in southern parts of the Arkansas River valley during the mid-1960's. One of these southern wells (well
28S-01W-11BCB) has a continuous record of water-level measurements and is included in this discussion of historic water-level fluctuations.

Well hydrographs for selected monitoring wells, showing the average seasonal depth to water from 1938 through 1985, are shown in figure 18 in conjunction with graphs showing seasonal precipitation and cumulative departure from average precipitation at Wichita, irrigated acres in Sedgwick County, and annual groundwater withdrawals for public supplies from the Wichita well field. Several of these wells are located far enough from areas where large volumes of ground water are withdrawn that they probably are unaffected by the withdrawals and should be representative of natural fluctuations in ground-water levels. The wells that are not affected by ground-water withdrawals are 25S-01W-14DDD and 25S-03W9CCC. Water levels in these wells are related directly to the cumulative departure from average precipitation. Evidence that water levels are not affected by ground-water withdrawals is given by the observation that these were the only wells with higher water levels in 1985 than in 1938; cumulative departure from average precipitation was also greater in 1985 than in 1938. All of the other wells had lower water levels in 1985 than in 1938.

Well 26S-01E-21BBB is adjacent to areas where large volumes of ground water are withdrawn for public and industrial supplies. However, the water level appears to have been only slightly affected. Wells 26S-01W-16DDD, 25S-03W-33BAA, and 26S-02W-10BBB are located in areas where the ground-water levels have been lowered by irrigation, primarily during the last 20 years. Well $26 \mathrm{~S}-02 \mathrm{~W}-10 \mathrm{BBB}$ is also adjacent to an area where ground water is withdrawn for industrial use and has experienced only a slight decline in the water level.

Wells 25S-02W-04AAA, 25S-02W-16BBB, and 25S-01W-17AAA are located in or adjacent to the Wichita well field. The water level in well 25S-02W-04AAA has declined more than 20 feet since 1941. Water levels in these wells probably are affected also by withdrawals for irrigation.

Well 28S-01W-11BCB has a much shorter 

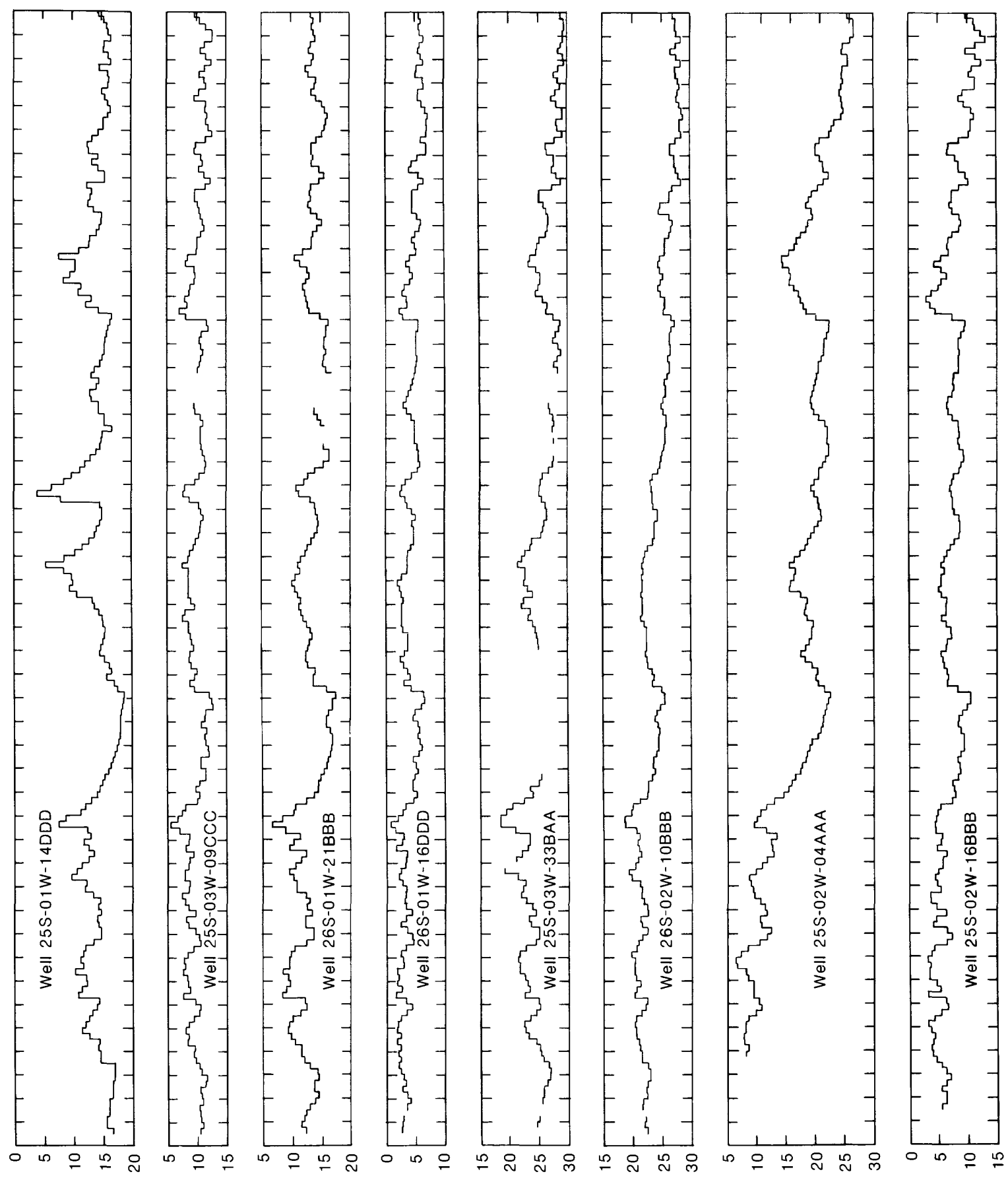

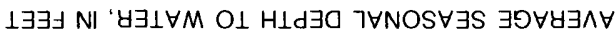



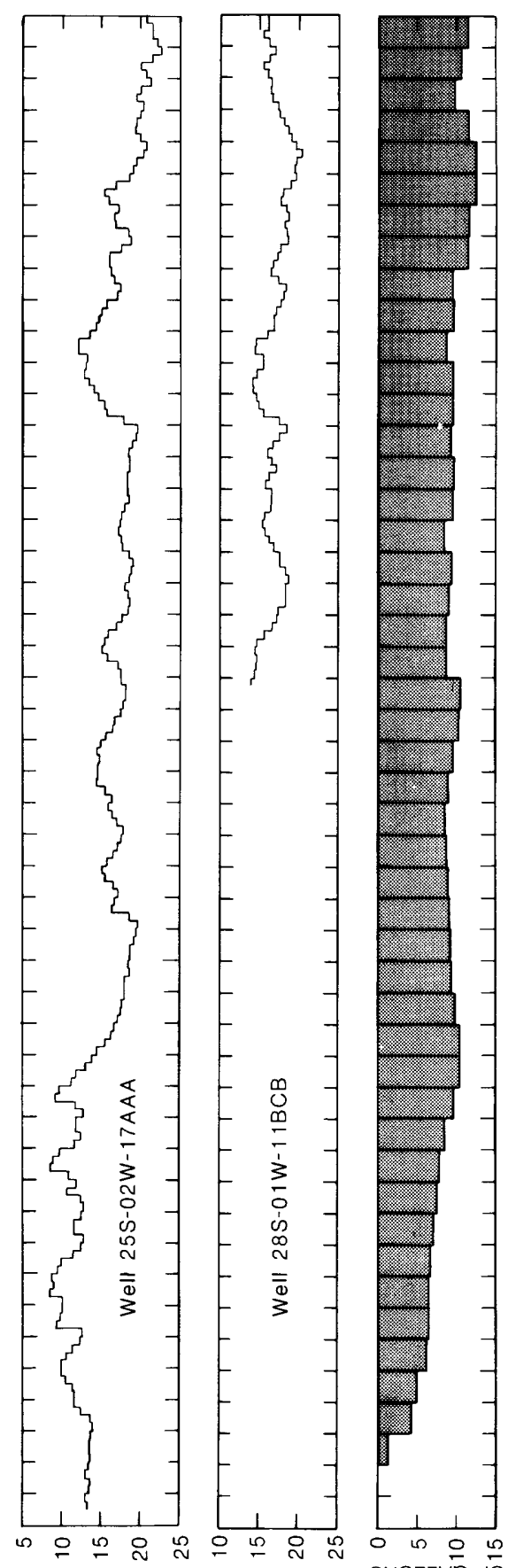
SNOา7Ұ5

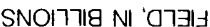
7 ר $\exists$ M $\forall I H O M M$ WOY SาM $\forall \forall O H \perp M \quad \forall \exists \perp \forall M$ - ONกOYD $7 \forall \cap N N \forall$
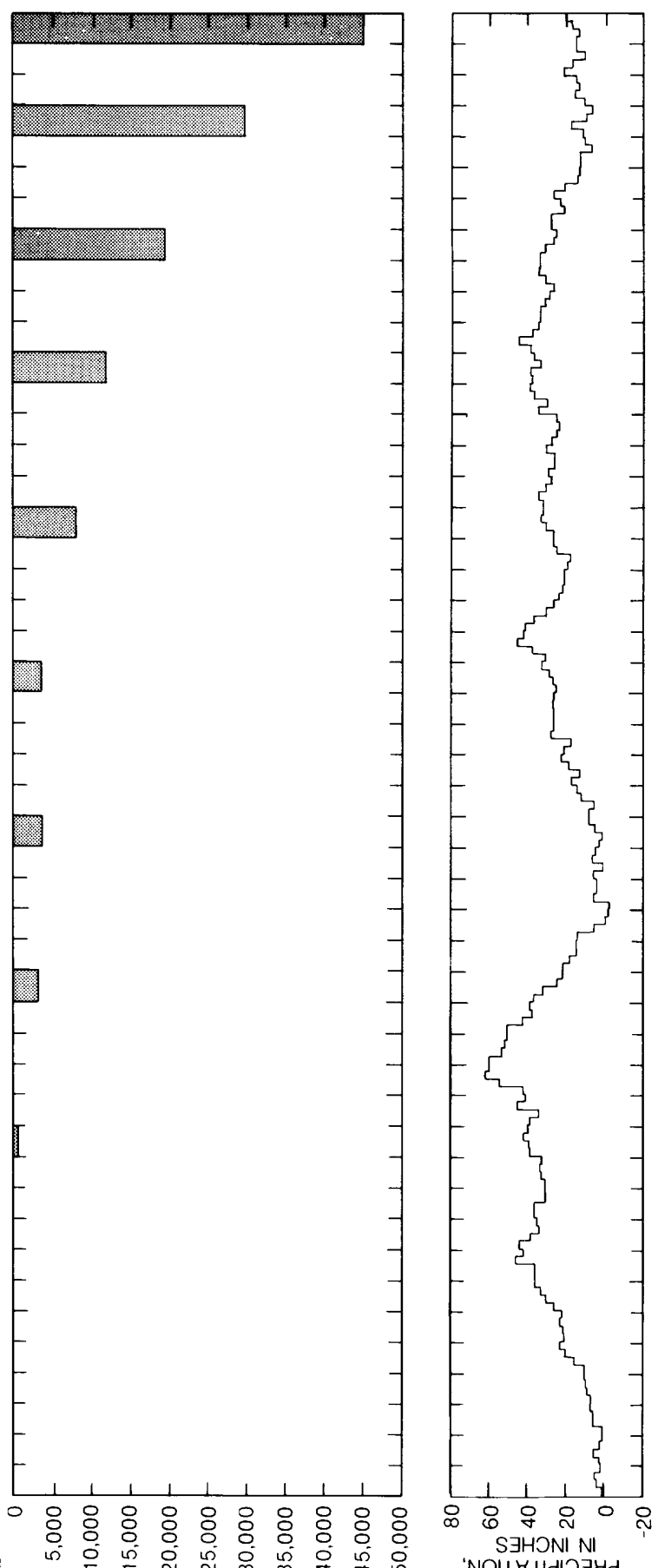
SᄏHONI NI NOII $\forall \perp$ IIOJyd $\exists \supseteq \forall \forall \exists \wedge \forall$ WOY $\exists y \cap \perp \forall \forall d \exists 0$

$\exists \wedge \mid \perp \forall า ก$ กกอ

范

ธ일

을

贾

은

突

잉

๘

$\Phi$

خ⿳⺈⿵冂⿰㐅㐅木

굳음

응

ن

茫

的 
period of record (1965-85) than the wells in the northern part of the county. Although it is located in an area where ground water is withdrawn for industrial supplies, the water level is closely related to cumulative departure from average precipitation and does not appear to have been affected significantly by ground-water withdrawals.

In general, ground-water levels in the area are directly related to cumulative departure from average precipitation. However, those wells located in and adjacent to the Wichita well field and in areas where large volumes of ground water are withdrawn for irrigation supplies have 1985 water levels that are the lowest observed during the period of record. Most of these declines are attributed to ground-water withdrawals. However, cumulative departure from average precipitation has declined also in recent years (since about 1975). An extended period of above-average precipitation, such as occurred during 1940-45, 1948-51, 1957-65, and 1973-75, probably would cause a substantial rise in ground-water levels. An extensive drought, such as occurred during 1952-56, probably would lower ground-water levels substantially.

\section{Depth to Water and Saturated Thickness}

The depth to water at any location is a function of both the ground-water elevation and local topography. The depth to water generally is least in areas adjacent to the Arkansas and Ninnescah Rivers where depth to water is often less than 10 feet and occasionally is less than 5 feet (plate 2). However, in areas adjacent to the Arkansas River in Wichita, depths are greater in areas where ground-water withdrawals have caused cones of depression to develop. In upland areas, the depth to water is greater, exceeding $\mathbf{4 0}$ feet in several of the measured wells.

The saturated thickness of unconsolidated deposits in Sedgwick County is shown in figure 19. The saturated-thickness map was developed by subtracting the altitude of the Permian (Wellington Formation or Ninnescah Shale) bedrock surface (from Lane and Miller, 1965a, plate 3) from the altitude of the ground-water surface, as shown on plate 2 of this report. Lines of equal saturated thickness in figure 19 are shown at 40-foot intervals for saturated thickness ranging from 20 to 220 feet. Areas where the saturated thickness is less than 20 feet are shaded. In the shaded areas, the unconsolidated deposits are thin or absent.

Saturated thickness is greatest in the northwest part of the county in the Arkansas River valley where it exceeds 220 feet in a few areas. Solution of the Hutchinson Salt Member of the Wellington Formation caused collapses and settling of the bedrock surface, resulting in a large closed depression that was subsequently filled with unconsolidated deposits (Lane and Miller, 1965a). Saturated thickness of unconsolidated deposits in the Arkansas River valley south of Wichita generally is less than 60 feet. Saturated thickness of unconsolidated deposits in the Ninnescah River valley ranges from about 40 feet along the river south of Clearwater to about 20 feet in alluvium of the North and South Forks of the Ninnescah River.

\section{Recharge, Storage, and Discharge}

Ground-water recharge occurs from precipitation, ground-water inflow from adjacent areas, and losing stream reaches. Precipitation is the primary source of ground-water recharge in the area. The quantity of recharge from precipitation in any area is a function of the quantity of precipitation, vegetation (interception and subsequent evaporation), seasonal factors (evaporation and evapotranspiration), topography (slope), soil conditions (permeability and antecedent soil moisture), and aquifer characteristics (permeability, porosity, depth to water, and capacity to store the recharge).

The Arkansas River valley unconsolidated aquifer in Sedgwick County is readily recharged by precipitation. The valley receives adequate precipitation (about 28.6 inches per year), is primarily grassland and cropland that intercepts less precipitation than forest vegetation, is relatively flat, which allows for less runoff and more infiltration, has sandy soil that is permeable, and has excellent aquifer characteristics provided by deep deposits of unconsolidated sand and gravel.

An investigation of recharge from precipitation in Harvey County, near Burrton (fig. 1), determined that effective recharge generally occurs only during late winter and spring (these are periods with relatively large amounts of precipitation and slow rates of evapotranspiration) (Sophocleous and Perry, 


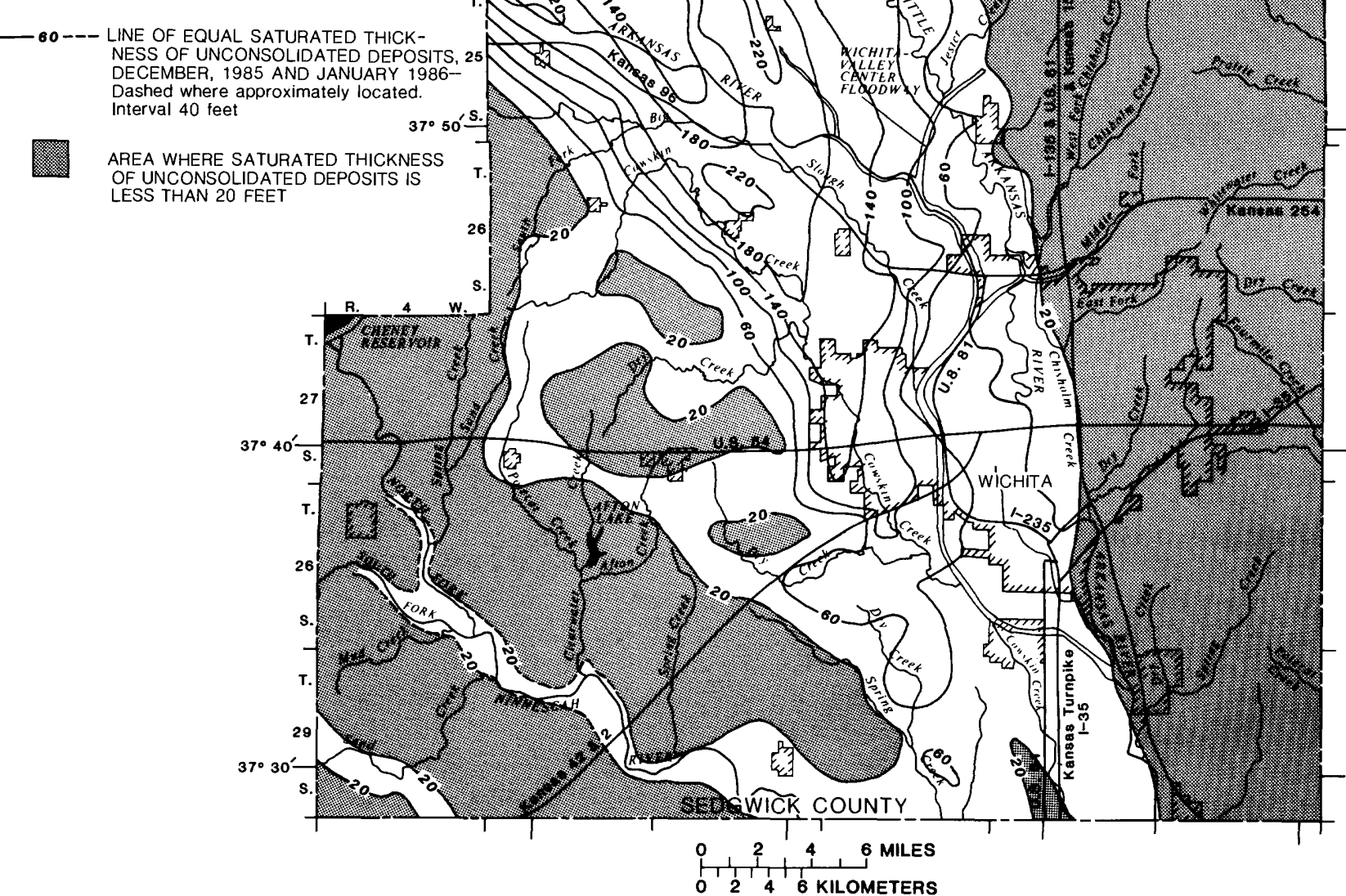

Figure 19. Saturated thickness of unconsolidated deposits in Sedgwick County.

1985). This same investigation indicated that the greater the thickness of the unsaturated zone (or the greater the depth to water) and the less available soil moisture (hydraulic conductivity decreases with decreasing soil moisture), the less recharge occurs (Sophocleous and Perry,1985). The areas investigated by Sophocleous and Perry were obvious recharge areas, sand-dune areas with no surface drainage patterns. In areas where surface runoff occurs, high levels of antecedent soil moisture can impede recharge by precipitation if the soil is near saturation. Recharge from precipitation in the Arkansas River valley of Sedgwick County and adjacent areas was estimated by Williams and Lohman (1949) at 5.32 to 8.37 inches per year, by Stramel (1956) at 3.75 to 8.80 inches per year, by Sophocleous (1983) at 1.6 to 6.4 inches per year, by Sophocleous and Perry (1985) at 6.06 inches per year, and by Spinazola and others (1985) at 0.1 to 5.5 inches per year.

Recharge from ground-water inflow is minimal in Sedgwick County. Water-level contours on plate 2 show that little ground-water inflow occurs along the northern boundary of the county because the contours are approximately normal to the boundary. Ground-water inflow to the Arkansas River valley does occur from uplands to the east and west, as indicated by the water-level contours. However, inflow is probably equal to the outflow indicated by waterlevel contours along the southern boundary of the county.

Recharge by losing streams generally does not occur in the area except during extended periods of high streamflow. The water-level contours on plate 2 indicate that the streams normally are either in relative equilibrium with the ground water (as the Arkansas River north of Wichita) or are gaining. Recharge from streams can occur in areas near the streams where ground-water withdrawals have created cones of depression. 
Storage of ground water with less than $1,000 \mathrm{mg} / \mathrm{L}$ dissolved solids in unconsolidated deposits of the Arkansas, Little Arkansas, and Ninnescah River valleys in Sedgwick County has been estimated to be about 2.88 million acre-feet (Hansen, 1987).

Ground-water discharge in the area is due primarily to gaining streams, evapotranspiration, and ground-water withdrawals. In general, over a long period, ground-water discharge is approximately equal to groundwater recharge, although ground-water withdrawals can upset this balance locally in areas of intensive pumping. In a natural setting (excluding ground-water withdrawals), most of the ground-water discharge occurs through gaining streams followed by evapotranspiration, which generally occurs only in areas where the depth to water is less than 10 feet (Spinazola and others, 1985). Spinazola and others estimated the maximum rate of ground-water discharge by evapotranspiration to be about 3.5 inches per year. In recent years, large ground-water withdrawals (about 112,700 acre-feet in 1985) may be approaching discharge to streams as a primary means of ground-water discharge.

During a low-flow seepage survey in March 1985, the Arkansas River gained only about 126 cubic feet per second between Mount Hope and Mulvane (excluding streamflow provided by the Little Arkansas River, table 11). However, part of the gain was due to sewagetreatment plant effluent from Wichita (probably about 60 cubic feet per second), so only about 66 cubic feet per second were gained. Ground-water withdrawals in Wichita and near Derby probably are decreasing the gain to some extent. The Little Arkansas River gained about 20 cubic feet per second between Sedgwick and 37th Street in Wichita (table 11), although the river is affected by ground-water withdrawals for public and industrial supplies. The Ninnescah River system experienced a gain of about 118 cubic feet per second in its reach through Sedgwick County. If these rates of gain are extrapolated to 1 year, the amount of ground-water loss to major streams in the county would be approximately 148,000 acre-feet per year.

\section{Water-Quality Characteristics}

Water samples for chemical analysis were collected from 99 wells during an areal reconnaissance of ground-water quality in August 1985. Two additional wells were sampled during February 1986. Wells in the reconnaissance network were selected to provide areal coverage and to represent the geology of the county. Where possible, wells with driller's logs describing the stratigraphy and providing other information, such as depth of well, water use, and estimated yield, were sampled. The results of chemical analysis of these samples and other information are provided in table 15. Pie diagrams showing the concentration of dissolved solids and the chemical composition of the water (based on milliequivalents per liter) for each well are plotted on plate 1.

\section{Relationship Between Ground-Water Quality and Geology}

Water-quality characteristics of ground water generally are functions of the mineralogy of the geologic formation containing the water and of the duration of contact between the water and minerals.

Water from wells in the Wellington Formation of Permian age generally is either a calcium sulfate, a calcium bicarbonate sulfate, or a calcium bicarbonate type. Calcium and bicarbonate are derived from the dissolution of impure limestone beds that occur in this formation. Calcium and sulfate are derived from the dissolution of gypsum and anhydrite beds. Concentrations of dissolved solids in the ground water generally increase with depth as the duration of contact between the water and minerals increases. In the Wellington Formation, calcium sulfate type water usually has concentrations of dissolved solids that exceed $1,000 \mathrm{mg} / \mathrm{L}$; calcium bicarbonate sulfate type water has concentrations of dissolved solids ranging from 500 to $1,000 \mathrm{mg} / \mathrm{L}$; and calcium bicarbonate type water has concentrations of dissolved solids that are less than $500 \mathrm{mg} / \mathrm{L}$. Calcium sulfate type water obtained from solution openings in gypsum and anhydrite beds in the extreme eastern part of the county, generally that part drained by eastward-flowing tributaries to the Walnut River, commonly is the most mineralized in the county, with concentrations of dissolved solids sometimes exceeding $2,000 \mathrm{mg} / \mathrm{L}$. Ground water from the 
Table 15. Water-quality data for selected wells in Sedgwick County, August 1985 and February 1986

$[<$ preceding a value indicates the constituent was not detected at that detection level]

WELL CHARACTERISTICS

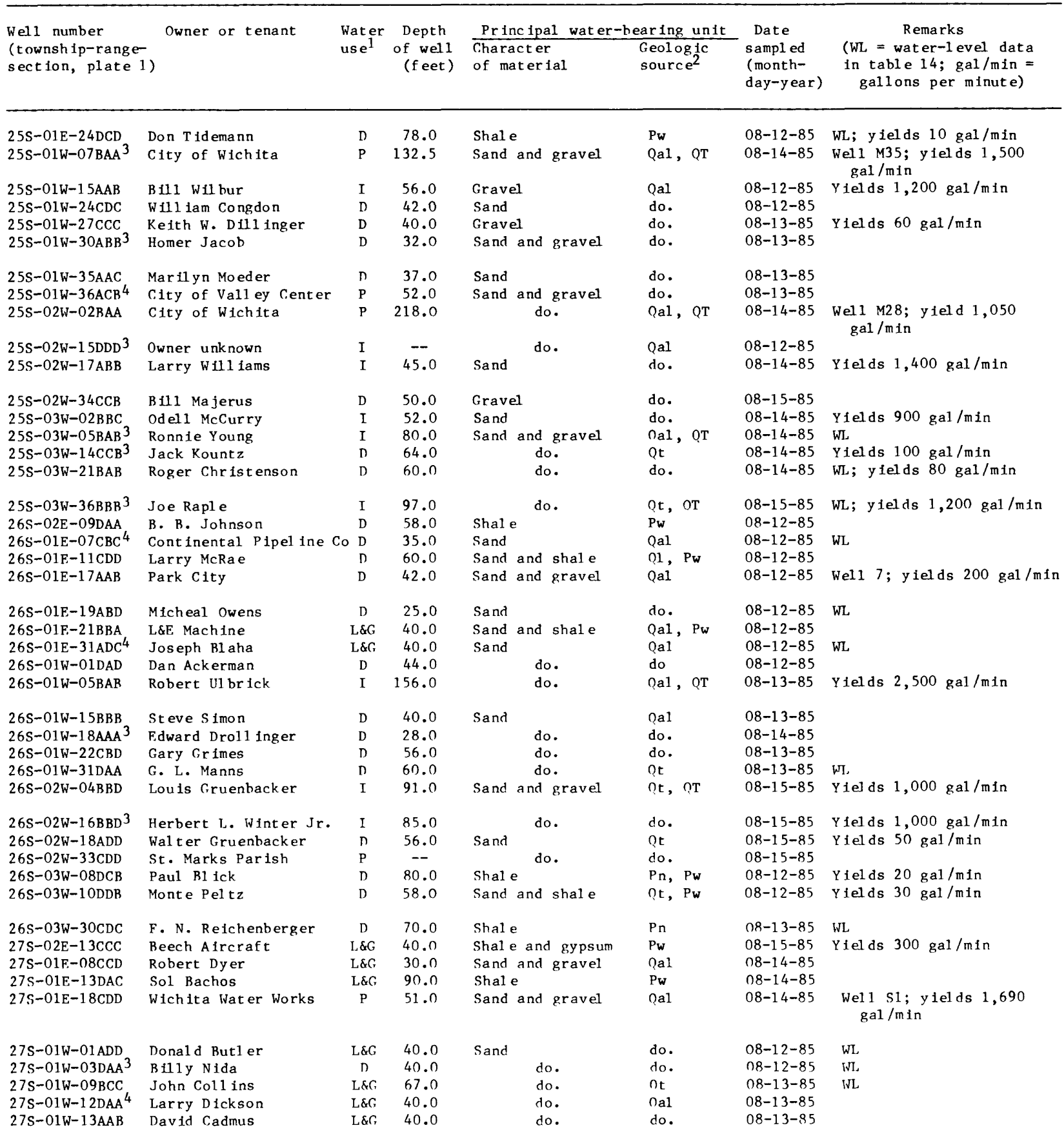


Table 15. Water-quality data for selected wells in Sedgwick County, August 1985 and February 1986 -. Continued

WELL CHARACTERISTICS--Cont Inued

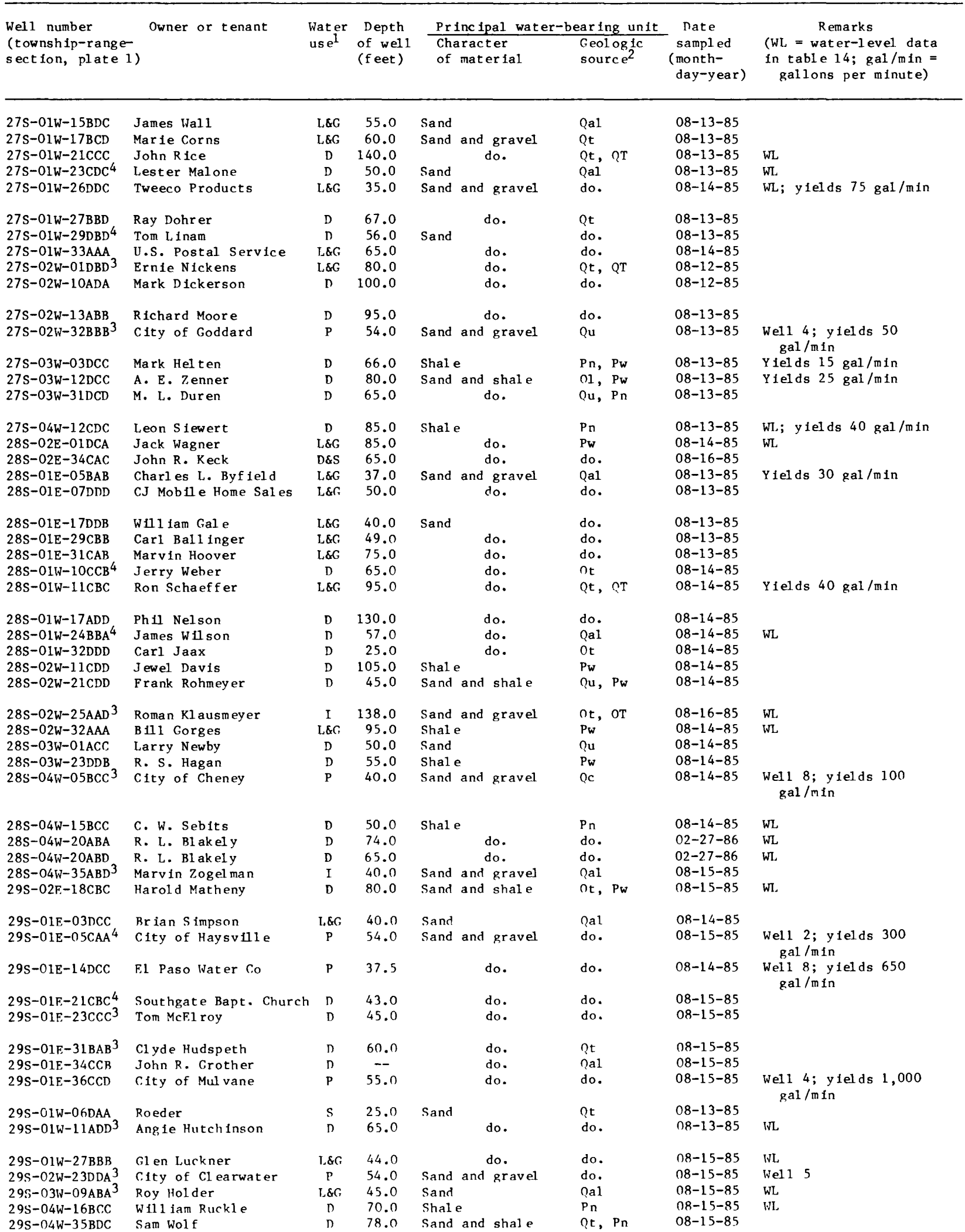


Table 15. Water-quality data for selected wells in Sedgwick County, August 1985 and February 1986 -Continued

PHYSICAL PROPERTIES AND INORGANIC CONSTITUENTS

\begin{tabular}{|c|c|c|c|c|c|c|c|c|c|c|c|}
\hline $\begin{array}{l}\text { Well number } \\
\text { (township-range- } \\
\text { section, plate 1) }\end{array}$ & $\begin{array}{l}\text { Time } \\
(24- \\
\text { hour })\end{array}$ & $\begin{array}{l}\text { Specif ic } \\
\text { conduct- } \\
\text { ance } \\
\text { (micro- } \\
\text { siemens } \\
\text { per cent 1- } \\
\text { meter at } \\
25 \text { degrees } \\
\text { Cel s ius }\end{array}$ & $\begin{array}{l}\quad \mathrm{pH} \\
\text { (stand- } \\
\text { ard } \\
\text { unfts) }\end{array}$ & $\begin{array}{l}\text { Water } \\
\text { temper- } \\
\text { ature } \\
\text { (degrees } \\
\text { Celsius) }\end{array}$ & $\begin{array}{l}\text { Hard- } \\
\text { ness, } \\
\text { (mili i- } \\
\text { grams } \\
\text { per } \\
1 \text { iter } \\
\text { as } \\
\mathrm{CaCO}_{3} \text { ) }\end{array}$ & $\begin{array}{l}\text { Hard- } \\
\text { ness, } \\
\text { noncar- } \\
\text { bonate } \\
\text { (mIl1 1- } \\
\text { grams } \\
\text { per } \\
1 \text { iter } \\
\text { as } \mathrm{CaCO}_{3} \text { ) }\end{array}$ & $\begin{array}{l}\text { Calcium, } \\
\text { dis- } \\
\text { solved } \\
\text { (milli- } \\
\text { grams } \\
\text { per } \\
\text { liter } \\
\text { as } \\
\text { Ca) }\end{array}$ & $\begin{array}{l}\text { Magne- } \\
\text { s lum, } \\
\text { dis- } \\
\text { solved } \\
\text { (milli- } \\
\text { grams } \\
\text { per } \\
1 \text { iter } \\
\text { as Mg) }\end{array}$ & $\begin{array}{l}\text { Sod lum, } \\
\text { dis } \\
\text { solved } \\
\text { (milli- } \\
\text { grams } \\
\text { per } \\
\text { liter } \\
\text { as } \mathrm{Na} \text { ) }\end{array}$ & $\begin{array}{l}\text { Sod lum- } \\
\text { adsorp- } \\
\text { t lon- } \\
\text { rat lo }\end{array}$ & $\begin{array}{l}\text { Potas- } \\
\text { sium, } \\
\text { dis- } \\
\text { solved } \\
\text { (milli- } \\
\text { grams } \\
\text { per } \\
1 \text { it er } \\
\text { as } K \text { ) }\end{array}$ \\
\hline $\begin{array}{l}25 S-01 E-24 D C D \\
25 S-01 W-07 B A A \\
25 S-01 W-15 A A B \\
25 S-01 W-24 C D C \\
25 S-01 W-27 C C C\end{array}$ & $\begin{array}{l}1515 \\
1045 \\
1400 \\
1315 \\
1120\end{array}$ & $\begin{array}{l}570 \\
622 \\
628 \\
630 \\
615\end{array}$ & $\begin{array}{l}7.6 \\
7.3 \\
7.5 \\
7.5 \\
7.3\end{array}$ & $\begin{array}{l}23.5 \\
15.5 \\
14.5 \\
17.0 \\
15.5\end{array}$ & $\begin{array}{l}290 \\
250 \\
240 \\
340 \\
250\end{array}$ & $\begin{array}{l}39 \\
42 \\
-- \\
44 \\
37\end{array}$ & $\begin{array}{r}91 \\
81 \\
75 \\
100 \\
79\end{array}$ & $\begin{array}{l}15 \\
12 \\
14 \\
23 \\
12\end{array}$ & $\begin{array}{l}29 \\
38 \\
24 \\
35 \\
37\end{array}$ & $\begin{array}{l}0.8 \\
1 \\
.7 \\
.9\end{array}$ & $\begin{array}{l}0.5 \\
2.6 \\
1.8 \\
3.7 \\
2.4\end{array}$ \\
\hline $\begin{array}{l}25 S-01 W-30 A B B \\
25 S-01 W-35 A A C \\
25 S-01 W-36 A C B \\
25 S-02 W-02 B A A \\
25 S-02 W-15 D D D\end{array}$ & $\begin{array}{l}1215 \\
0940 \\
1030 \\
1030 \\
1530\end{array}$ & $\begin{array}{l}805 \\
940 \\
822 \\
785 \\
626\end{array}$ & $\begin{array}{l}7.2 \\
7.2 \\
7.2 \\
7.5 \\
8.1\end{array}$ & $\begin{array}{l}15.0 \\
17.5 \\
16.0 \\
16.0 \\
25.0\end{array}$ & $\begin{array}{l}280 \\
460 \\
320 \\
240 \\
200\end{array}$ & $\begin{array}{r}86 \\
170 \\
26 \\
- \\
37\end{array}$ & $\begin{array}{r}89 \\
150 \\
91 \\
76 \\
59\end{array}$ & $\begin{array}{l}13 \\
20 \\
22 \\
13 \\
12\end{array}$ & $\begin{array}{l}51 \\
38 \\
33 \\
78 \\
40\end{array}$ & $\begin{array}{l}.8 \\
.8 \\
1 \\
.8\end{array}$ & $\begin{array}{l}9.7 \\
2.6 \\
2.0 \\
2.9 \\
3.1\end{array}$ \\
\hline $\begin{array}{l}25 S-02 W-17 A B B \\
25 S-02 W-34 C C B \\
25 S-03 W-02 B B C \\
25 S-03 W-05 B A B \\
25 S-03 w-14 C C B\end{array}$ & $\begin{array}{l}1200 \\
1120 \\
1245 \\
1330 \\
1510\end{array}$ & $\begin{array}{r}960 \\
2,990 \\
986 \\
1,180 \\
2,350\end{array}$ & $\begin{array}{l}7.2 \\
7.6 \\
7.2 \\
7.5 \\
7.5\end{array}$ & $\begin{array}{l}14.5 \\
16.0 \\
15.0 \\
15.0 \\
15.0\end{array}$ & $\begin{array}{r}300 \\
27 \\
330 \\
190 \\
420\end{array}$ & $\begin{array}{r}120 \\
-- \\
48 \\
220\end{array}$ & $\begin{array}{c}94 \\
8.3 \\
100 \\
57 \\
120\end{array}$ & $\begin{array}{l}17 \\
1.5 \\
19 \\
11 \\
29\end{array}$ & $\begin{array}{r}77 \\
600 \\
88 \\
140 \\
270\end{array}$ & $\begin{array}{r}2 \\
52 \\
2 \\
5 \\
6\end{array}$ & $\begin{array}{l}3.4 \\
3.0 \\
3.0 \\
2.9 \\
5.5\end{array}$ \\
\hline $\begin{array}{l}25 S-03 W-21 B A B \\
25 S-03 W-36 B B B \\
26 S-02 E-09 D A A \\
26 S-01 E-07 C B C \\
26 S-01 E-11 C D D\end{array}$ & $\begin{array}{l}1415 \\
1345 \\
1300 \\
1200 \\
1400\end{array}$ & $\begin{array}{r}592 \\
1,100 \\
3,100 \\
890 \\
675\end{array}$ & $\begin{array}{l}7.0 \\
7.5 \\
7.0 \\
6.7 \\
7.6\end{array}$ & $\begin{array}{l}16.0 \\
15.0 \\
22.0 \\
22.0 \\
19.0\end{array}$ & $\begin{array}{r}210 \\
190 \\
1,800 \\
330 \\
300\end{array}$ & $\begin{array}{r}-- \\
-- \\
1,600 \\
--\end{array}$ & $\begin{array}{r}64 \\
58 \\
570 \\
100 \\
96\end{array}$ & $\begin{array}{l}13 \\
11 \\
96 \\
20 \\
15\end{array}$ & $\begin{array}{r}50 \\
150 \\
89 \\
61 \\
35\end{array}$ & $\begin{array}{l}2 \\
5 \\
2.9\end{array}$ & $\begin{array}{l}2.9 \\
2.6 \\
4.8 \\
3.4 \\
1.2\end{array}$ \\
\hline $\begin{array}{l}26 S-01 E-17 A A B \\
26 S-01 E-19 A B D \\
26 S-01 E-21 B B A \\
26 S-01 E-31 A D C \\
26 S-01 W-01 D A D\end{array}$ & $\begin{array}{l}1300 \\
1400 \\
1620 \\
1745 \\
1220\end{array}$ & $\begin{array}{r}1,060 \\
1,450 \\
1,160 \\
1,910 \\
653\end{array}$ & $\begin{array}{l}7.1 \\
6.9 \\
7.4 \\
7.2 \\
7.3\end{array}$ & $\begin{array}{l}15.0 \\
16.5 \\
15.0 \\
16.5 \\
17.0\end{array}$ & $\begin{array}{l}390 \\
340 \\
460 \\
340 \\
280\end{array}$ & $\begin{array}{r}36 \\
66 \\
100 \\
91 \\
7\end{array}$ & $\begin{array}{r}100 \\
100 \\
120 \\
97 \\
88\end{array}$ & $\begin{array}{l}33 \\
21 \\
40 \\
24 \\
14\end{array}$ & $\begin{array}{r}48 \\
150 \\
91 \\
240 \\
53\end{array}$ & $\begin{array}{l}1 \\
4 \\
2 \\
6 \\
1\end{array}$ & $\begin{array}{l}2.3 \\
4.0 \\
2.0 \\
5.4 \\
2.3\end{array}$ \\
\hline $\begin{array}{l}26 \mathrm{~S}-01 \mathrm{~W}-05 \mathrm{BAB} \\
26 \mathrm{~S}-01 \mathrm{~W}-15 \mathrm{BBB} \\
26 \mathrm{~S}-01 \mathrm{~W}-18 \mathrm{AAA} \\
26 \mathrm{~S}-01 \mathrm{~W}-22 \mathrm{CBD} \\
26 \mathrm{~S}-01 \mathrm{~W}-31 \mathrm{DAA}\end{array}$ & $\begin{array}{l}1300 \\
1410 \\
1600 \\
1440 \\
1510\end{array}$ & $\begin{array}{r}2,090 \\
2,550 \\
2,130 \\
2,020 \\
580\end{array}$ & $\begin{array}{l}7.4 \\
7.6 \\
7.4 \\
7.3 \\
7.2\end{array}$ & $\begin{array}{l}15.0 \\
19.0 \\
16.0 \\
17.0 \\
16.0\end{array}$ & $\begin{array}{l}420 \\
480 \\
560 \\
550 \\
120\end{array}$ & $\begin{array}{r}230 \\
270 \\
330 \\
350 \\
--\end{array}$ & $\begin{array}{r}130 \\
140 \\
180 \\
170 \\
37\end{array}$ & $\begin{array}{r}24 \\
32 \\
26 \\
31 \\
6.9\end{array}$ & $\begin{array}{r}280 \\
370 \\
230 \\
200 \\
76\end{array}$ & $\begin{array}{l}6 \\
8 \\
4 \\
4 \\
3\end{array}$ & $\begin{array}{l}4.6 \\
6.6 \\
6.1 \\
4.9 \\
2.4\end{array}$ \\
\hline $\begin{array}{l}26 S-02 W-04 B B D \\
26 S-02 W-16 B B D \\
26 S-02 W-18 A D D \\
26 S-02 W-33 C D D \\
26 S-03 W-08 D C B\end{array}$ & $\begin{array}{l}1030 \\
1230 \\
1630 \\
1530 \\
1220\end{array}$ & $\begin{array}{r}1,730 \\
708 \\
515 \\
750 \\
2,250\end{array}$ & $\begin{array}{l}7.4 \\
7.6 \\
7.1 \\
7.3 \\
6.9\end{array}$ & $\begin{array}{l}15.0 \\
15.0 \\
16.0 \\
15.0 \\
15.0\end{array}$ & $\begin{array}{r}480 \\
270 \\
210 \\
230 \\
1,000\end{array}$ & $\begin{array}{c}230 \\
-- \\
-- \\
-- \\
790\end{array}$ & $\begin{array}{r}150 \\
85 \\
65 \\
63 \\
300\end{array}$ & $\begin{array}{l}25 \\
14 \\
11 \\
18 \\
72\end{array}$ & $\begin{array}{r}170 \\
50 \\
35 \\
61 \\
120\end{array}$ & $\begin{array}{l}4 \\
1 \\
1 \\
2 \\
2\end{array}$ & $\begin{array}{l}3.7 \\
2.4 \\
1.8 \\
2.0 \\
2.4\end{array}$ \\
\hline $\begin{array}{l}26 S-03 W-10 D D B \\
26 S-03 W-30 C D C \\
27 S-02 E-13 C C C \\
27 S-01 E-08 C C D \\
27 S-01 E-13 D A C\end{array}$ & $\begin{array}{l}1320 \\
1120 \\
1100 \\
1145 \\
1300\end{array}$ & $\begin{array}{r}665 \\
1,050 \\
2,800 \\
1,150 \\
1,630\end{array}$ & $\begin{array}{l}7.2 \\
7.3 \\
7.4 \\
7.5 \\
7.3\end{array}$ & $\begin{array}{l}16.0 \\
15.5 \\
15.0 \\
20.0 \\
16.5\end{array}$ & $\begin{array}{r}290 \\
370 \\
1,900 \\
300 \\
780\end{array}$ & $\begin{array}{r}16 \\
49 \\
1,600 \\
45 \\
400\end{array}$ & $\begin{array}{r}85 \\
100 \\
600 \\
89 \\
210\end{array}$ & $\begin{array}{l}18 \\
29 \\
89 \\
20 \\
61\end{array}$ & $\begin{array}{r}43 \\
72 \\
68 \\
120 \\
97\end{array}$ & $3_{2}^{1} \cdot 7$ & $\begin{array}{l}1.8 \\
1.7 \\
4.0 \\
4.1 \\
1.2\end{array}$ \\
\hline $\begin{array}{l}27 \mathrm{~S}-01 \mathrm{E}-18 \mathrm{CDD} \\
27 \mathrm{~S}-01 \mathrm{~W}-01 \mathrm{ADD} \\
27 \mathrm{~S}-01 \mathrm{~W}-03 \mathrm{DAA} \\
27 \mathrm{~S}-01 \mathrm{~W}-09 \mathrm{BCC} \\
27 \mathrm{~S}-01 \mathrm{~W}-12 \mathrm{DAA}\end{array}$ & $\begin{array}{l}1100 \\
1600 \\
1700 \\
0945 \\
1030\end{array}$ & $\begin{array}{r}1,570 \\
1,950 \\
1,610 \\
407 \\
1,220\end{array}$ & $\begin{array}{l}7.6 \\
7.4 \\
7.3 \\
6.8 \\
7.2\end{array}$ & $\begin{array}{l}15.5 \\
15.0 \\
15.5 \\
17.5 \\
17.0\end{array}$ & $\begin{array}{l}480 \\
280 \\
270 \\
120 \\
320\end{array}$ & $\begin{array}{r}160 \\
80 \\
130 \\
-- \\
150\end{array}$ & $\begin{array}{r}140 \\
79 \\
82 \\
38 \\
95\end{array}$ & $\begin{array}{l}31 \\
20 \\
15 \\
6.6 \\
21\end{array}$ & $\begin{array}{r}170 \\
280 \\
210 \\
44 \\
120\end{array}$ & $\begin{array}{l}4 \\
8 \\
6 \\
2 \\
3\end{array}$ & $\begin{array}{l}6.4 \\
6.0 \\
4.2 \\
4.6 \\
4.2\end{array}$ \\
\hline $\begin{array}{l}27 \mathrm{~S}-01 \mathrm{~W}-13 \mathrm{AAB} \\
27 \mathrm{~S}-01 \mathrm{~W}-15 \mathrm{BDC} \\
27 \mathrm{~S}-01 \mathrm{~W}-17 \mathrm{BCD} \\
27 \mathrm{~S}-01 \mathrm{~W}-21 \mathrm{CCC} \\
27 \mathrm{~S}-01 \mathrm{~W}-23 \mathrm{CDC}\end{array}$ & $\begin{array}{l}1115 \\
1315 \\
1230 \\
1500 \\
1545\end{array}$ & $\begin{array}{r}1,460 \\
663 \\
691 \\
730 \\
964\end{array}$ & $\begin{array}{l}7.3 \\
6.8 \\
7.0 \\
6.8 \\
7.3\end{array}$ & $\begin{array}{l}16.0 \\
16.0 \\
17.0 \\
15.5 \\
16.0\end{array}$ & $\begin{array}{l}350 \\
160 \\
240 \\
230 \\
140\end{array}$ & $\begin{array}{c}130 \\
-- \\
-- \\
--\end{array}$ & $\begin{array}{r}110 \\
51 \\
76 \\
71 \\
44\end{array}$ & $\begin{array}{l}18 \\
8.1 \\
13 \\
13 \\
8.4\end{array}$ & $\begin{array}{r}190 \\
93 \\
61 \\
77 \\
140\end{array}$ & $\begin{array}{l}5 \\
3 \\
2 \\
2 \\
5\end{array}$ & $\begin{array}{l}3.1 \\
2.6 \\
3.2 \\
2.4 \\
2.5\end{array}$ \\
\hline
\end{tabular}


Table 15. Water-quality data for selected wells in Sedgwick County, August 1985 and February 1986-Continued

PHYSICAL PROPERTIES AND INORGANIC CONSTITUFNTS--Cont inued

\begin{tabular}{|c|c|c|c|c|c|c|c|c|c|c|c|}
\hline $\begin{array}{l}\text { Wel } 1 \text { number } \\
\text { (township-range- } \\
\text { section, plate } 1 \text { ) }\end{array}$ & $\begin{array}{l}\text { T tme } \\
(24- \\
\text { hour) }\end{array}$ & $\begin{array}{l}\text { Spe- } \\
\text { clf ic } \\
\text { conduct- } \\
\text { ance } \\
\text { (micro- } \\
\text { siemens } \\
\text { per cent 1- } \\
\text { meter at } \\
25 \text { degrees } \\
\text { Celsius) }\end{array}$ & $\begin{array}{l}\mathrm{pH} \\
\text { (stand- } \\
\text { ard } \\
\text { untts) } \\
- \\
-\end{array}$ & $\begin{array}{l}\text { Water } \\
\text { temper- } \\
\text { ature } \\
\text { (degrees } \\
\text { Celsius) }\end{array}$ & $\begin{array}{l}\text { Hard- } \\
\text { ness } \\
\text { noncar- } \\
\text { bonate } \\
\text { (mill 1- } \\
\text { grams } \\
\text { per } \\
1 \text { fter as } \\
\mathrm{CaCO}_{3} \text { ) }\end{array}$ & $\begin{array}{l}\text { Hard- } \\
\text { ness } \\
\text { (mill } \mathrm{f}^{-} \\
\text {grams } \\
\text { per } \\
1 \mathrm{fter} \\
\text { as } \\
\mathrm{CaCO}_{3} \text { ) }\end{array}$ & $\begin{array}{l}\text { Calcium, } \\
\text { dis- } \\
\text { solved } \\
\text { (milli- } \\
\text { grams } \\
\text { per } \\
\text { liter } \\
\text { as } \\
\text { Ca) }\end{array}$ & $\begin{array}{l}\text { Magne- } \\
\text { slum, } \\
\text { dis- } \\
\text { solved } \\
\text { (mill 1- } \\
\text { grams } \\
\text { per } \\
\text { liter } \\
\text { as } \mathrm{Mg} \text { ) }\end{array}$ & $\begin{array}{l}\text { Sodtum, } \\
\text { dis- } \\
\text { solved } \\
\text { (mill } 1- \\
\text { grams } \\
\text { per } \\
\text { liter } \\
\text { as } \mathrm{Na} \text { ) }\end{array}$ & $\begin{array}{l}\text { Sodium- } \\
\text { adsorp- } \\
\text { ton- } \\
\text { rat io }\end{array}$ & $\begin{array}{l}\text { Potas- } \\
\text { sium, } \\
\text { dis- } \\
\text { solved } \\
\text { (mill1- } \\
\text { grams } \\
\text { per } \\
1 \text { iter } \\
\text { as } \mathrm{K} \text { ) }\end{array}$ \\
\hline $27 \mathrm{~S}-01 \mathrm{~W}-26 \mathrm{DDC}$ & 1115 & 888 & 7.3 & 17.0 & 220 & - & 70 & 12 & 110 & 3 & 3.0 \\
\hline $27 \mathrm{~s}-01 \mathrm{~W}-27 \mathrm{BBD}$ & 1800 & 845 & 7.1 & 16.0 & 160 & -- & 49 & 8.6 & 140 & 5 & 2.4 \\
\hline $27 S-01 W-29 D B D$ & 1700 & 1,770 & 6.8 & 16.0 & 410 & 130 & 130 & 21 & 210 & 5 & 2.8 \\
\hline $27 \mathrm{~S}-01 \mathrm{~W}-33 \mathrm{AAA}$ & 1000 & 639 & 7.2 & 15.5 & 110 & -- & 34 & 6.1 & 100 & 4 & 2.1 \\
\hline $27 S-02 W-01 D B D$ & 1440 & 1,400 & 7.1 & 16.5 & 400 & 140 & 120 & 25 & 120 & 3 & 3.1 \\
\hline $27 \mathrm{~S}-02 \mathrm{~W}-10 \mathrm{ADA}$ & 1525 & 720 & 7.3 & 14.5 & 230 & -- & 65 & 16 & 74 & 2 & 2.1 \\
\hline $17 \mathrm{~S}-02 \mathrm{~W}-13 \mathrm{ABB}$ & 0850 & 765 & 7.1 & 20.0 & 250 & -- & 73 & 16 & 67 & 2 & 2.2 \\
\hline $27 S-03 W-03 D C C$ & 1245 & 1,190 & 7.1 & 16.5 & 510 & 140 & 170 & 20 & 56 & 1 & 1.6 \\
\hline $27 \mathrm{~S}-03 \mathrm{~W}-12 \mathrm{DCC}$ & 1015 & 1,290 & 7.2 & 16.0 & 420 & 130 & 130 & 24 & 100 & 2 & 1.2 \\
\hline $27 S-03 W-31 D C D$ & 1345 & 355 & 7.4 & 14.5 & 140 & 57 & 41 & 8.5 & 17 & .7 & 1.8 \\
\hline $27 S-04 W-12 C D C$ & 1210 & 1,950 & 7.2 & 15.5 & 750 & 530 & 180 & 72 & 150 & 2 & 2.9 \\
\hline $28 \mathrm{~S}-02 \mathrm{E}-01 \mathrm{DCA}$ & 1530 & 1,890 & 7.1 & 15.5 & 1,200 & 1,000 & 380 & 67 & 45 & .6 & 1.9 \\
\hline $28 \mathrm{~S}-02 \mathrm{E}-34 \mathrm{CAC}$ & 1030 & 1,050 & 7.5 & 19.0 & 610 & 290 & 180 & 40 & 27 & .5 & 1.9 \\
\hline $28 \mathrm{~S}-01 \mathrm{E}-05 \mathrm{BAB}$ & 1730 & 1,900 & 7.2 & 16.5 & 420 & 59 & 130 & 23 & 240 & 5 & 4.2 \\
\hline $28 S-01 E-07 D D D$ & 1030 & 1,550 & 7.1 & 15.0 & 450 & 130 & 140 & 25 & 180 & 4 & 4.7 \\
\hline $28 \mathrm{~S}-01 \mathrm{E}-17 \mathrm{DDB}$ & 1130 & 1,240 & 7.3 & 15.5 & 240 & 38 & 69 & 16 & 160 & 5 & 3.8 \\
\hline $28 \mathrm{~S}-01 \mathrm{E}-29 \mathrm{CBB}$ & 1230 & 1,070 & 7.3 & 16.0 & 340 & 61 & 110 & 16 & 110 & 3 & 4.7 \\
\hline $28 \mathrm{~S}-01 \mathrm{E}-31 \mathrm{CAB}$ & 1300 & 1,000 & 6.9 & 15.5 & 400 & 300 & 120 & 24 & 45 & 1 & 1.7 \\
\hline $28 s-01 W-10 \mathrm{CCB}$ & 1215 & 545 & 7.1 & 15.5 & 150 & - & 47 & 8.4 & 61 & 2 & 2.1 \\
\hline $28 \mathrm{~S}-01 \mathrm{~W}-11 \mathrm{CBC}$ & 1300 & 841 & 7.5 & 15.5 & 83 & - & 26 & 4.3 & 160 & 8 & 1.9 \\
\hline $28 S-01 W-17 A D D$ & 1330 & 960 & 7.3 & 16.0 & 410 & 270 & 110 & 32 & 37 & .8 & 3.1 \\
\hline $28 \mathrm{~S}-01 \mathrm{~W}-24 \mathrm{BBA}$ & 1430 & 1,320 & 7.3 & 15.0 & 300 & 7 & 94 & 15 & 180 & 5 & 3.1 \\
\hline $28 \mathrm{~S}-02 \mathrm{~W}-21 \mathrm{CDD}$ & 1020 & 390 & 7.4 & 15.5 & 130 & -- & 39 & 7.9 & 31 & 1 & 2.0 \\
\hline $28 \mathrm{~S}-02 \mathrm{~W}-25 \mathrm{AAD}$ & 0900 & 1,030 & 7.4 & 15.5 & 350 & 73 & 110 & 19 & 49 & 1 & 3.5 \\
\hline $28 \mathrm{~S}-02 \mathrm{~W}-32 \mathrm{AAA}$ & 1215 & 1,850 & 7.4 & 16.0 & 770 & 560 & 210 & 59 & 140 & 2 & 3.1 \\
\hline $28 \mathrm{~S}-03 \mathrm{~W}-01 \mathrm{ACC}$ & 1510 & 600 & 7.1 & 14.5 & 360 & 1 & 120 & 15 & 39 & .9 & 2.3 \\
\hline $28 S-03 W-23 D D B$ & 1250 & 1,010 & 7.3 & 17.0 & 330 & 150 & 100 & 19 & 81 & 2 & 1.6 \\
\hline $28 S-04 W-05 B C C$ & 1600 & 895 & 7.3 & 16.0 & 390 & 250 & 120 & 21 & 23 & .5 & 3.8 \\
\hline $28 \mathrm{~S}-04 \mathrm{~W}-15 \mathrm{BCC}$ & 1640 & 680 & 7.4 & 18.0 & 320 & 87 & 74 & 32 & 24 & .6 & 2.8 \\
\hline $28 \mathrm{~S}-04 \mathrm{~W}-20 \mathrm{ABA}$ & 1315 & 1,740 & 7.3 & 16.0 & 810 & 690 & 240 & 52 & 75 & 1 & 3.3 \\
\hline $28 S-04 W-20 A B D$ & 1330 & 1,870 & 7.5 & 14.0 & 950 & 830 & 290 & 55 & 77 & 1 & 3.2 \\
\hline $28 S-04 W-35 A B D$ & 1420 & 1,390 & 7.6 & 14.5 & 530 & 340 & 140 & 45 & 60 & 1 & 2.1 \\
\hline $29 \mathrm{~S}-02 \mathrm{E}-18 \mathrm{CBC}$ & 1345 & 650 & 7.5 & 19.5 & 270 & 12 & 86 & 14 & 47 & 1 & 1.4 \\
\hline $29 S-01 E-03 D C C$ & 1730 & 970 & 7.3 & 15.0 & 470 & 160 & 150 & 22 & 38 & .8 & 2.0 \\
\hline $29 \mathrm{~S}-01 \mathrm{E}-05 \mathrm{CAA}$ & 1045 & 1,080 & 7.2 & 15.0 & 330 & 38 & 100 & 19 & 85 & 2 & 3.3 \\
\hline $29 \mathrm{~S}-01 \mathrm{E}-14 \mathrm{DCC}$ & 1630 & 900 & 6.8 & 15.0 & 400 & 120 & 130 & 19 & 61 & 1 & 3.1 \\
\hline $29 S-01 E-21 C B C$ & 1215 & 636 & 7.2 & 16.0 & 250 & - & 79 & 12 & 44 & 1 & 1.9 \\
\hline $29 S-01 E-23 C C C$ & 1800 & 630 & 7.2 & 17.0 & 270 & 49 & 88 & 12 & 36 & 1 & 3.3 \\
\hline $29 S-01 E-31 B A B$ & 1315 & 662 & 7.1 & 16.0 & 220 & 26 & 65 & 13 & 41 & 1 & 2.8 \\
\hline $29 \mathrm{~S}-01 \mathrm{E}-34 \mathrm{CCB}$ & 1700 & 920 & 7.0 & 18.0 & 440 & 140 & 140 & 22 & 26 & .6 & 3.7 \\
\hline $29 \mathrm{~S}-01 \mathrm{E}-36 \mathrm{CCD}$ & 1620 & 780 & 7.2 & 15.0 & 300 & 7 & 96 & 14 & 50 & 1 & 3.1 \\
\hline $29 \mathrm{~S}-01 \mathrm{~W}-06 \mathrm{DAA}$ & 1620 & 900 & 7.3 & 15.0 & 430 & 340 & 130 & 25 & 39 & .9 & 2.0 \\
\hline $29 S-01 W-11 A D D$ & 1400 & 345 & 7.0 & 21.0 & 150 & -- & 47 & 8.7 & 36 & 1 & 2.4 \\
\hline $29 \mathrm{~S}-01 \mathrm{~W}-27 \mathrm{BBB}$ & 1415 & 698 & 7.1 & 16.0 & 250 & 11 & 66 & 21 & 39 & 1 & 1.2 \\
\hline $29 \mathrm{~S}-02 \mathrm{~W}-23 \mathrm{DDA}$ & 1010 & 665 & 7.4 & 16.0 & 270 & 57 & 74 & 20 & 42 & 1 & 2.3 \\
\hline $29 \mathrm{~S}-03 \mathrm{~W}-09 \mathrm{ABA}$ & 1100 & 570 & 7.7 & 14.5 & 270 & 70 & 70 & 23 & 22 & .6 & 1.0 \\
\hline $29 \mathrm{~S}-04 \mathrm{~W}-16 \mathrm{BCC}$ & 1315 & 850 & 7.7 & 17.0 & 5 & -- & 1.5 & .4 & 180 & 35 & .6 \\
\hline $29 \mathrm{~S}-04 \mathrm{~W}-35 \mathrm{BDC}$ & 1230 & 760 & 7.7 & 17.0 & 280 & 95 & 63 & 31 & 42 & 1 & 1.8 \\
\hline
\end{tabular}


Table 15. Water-quality data for selected wells in Sedgwick County, August 1985 and February 1986-Continued

PHYSICAL PROPERTIES AND INORGANIC CONSTITUENTS--CONtinued

\begin{tabular}{|c|c|c|c|c|c|c|c|c|c|c|c|}
\hline $\begin{array}{l}\text { Well number } \\
\text { (township-range- } \\
\text { section, plate } 1 \text { ) }\end{array}$ & $\begin{array}{l}\text { Alka- } \\
1 \text { inity, } \\
\text { (mill i- } \\
\text { grams } \\
\text { per } \\
1 \text { iter } \\
\text { as } \mathrm{CaCO}_{3} \text { ) }\end{array}$ & $\begin{array}{l}\text { Sulfate } \\
\text { dis- } \\
\text { solved } \\
\text { (mill1- } \\
\text { grams } \\
\text { per } \\
1 \text { iter } \\
\text { as } \mathrm{SO}_{4} \text { ) }\end{array}$ & $\begin{array}{l}\text { Chlo- } \\
\text { ride, } \\
\text { dis- } \\
\text { solved } \\
\text { (milli- } \\
\text { grams } \\
\text { per } \\
1 \text { it er } \\
\text { as } C 1 \text { ) }\end{array}$ & $\begin{array}{l}\text { Fluo- } \\
\text { ride, } \\
\text { dis- } \\
\text { solved } \\
\text { (milli- } \\
\text { grams } \\
\text { per } \\
\text { liter } \\
\text { as F) }\end{array}$ & $\begin{array}{l}\text { Rromide, } \\
\text { dis- } \\
\text { solved } \\
\text { (milli- } \\
\text { grams } \\
\text { per } \\
\text { liter } \\
\text { as } \\
\text { Br) }\end{array}$ & $\begin{array}{l}\text { Silica, } \\
\text { dis- } \\
\text { solved } \\
\text { (milli- } \\
\text { grams } \\
\text { per } \\
11 \text { ter } \\
\text { as } \\
\mathrm{SiO}_{2} \text { ) }\end{array}$ & $\begin{array}{l}\text { Solids, } \\
\text { dis- } \\
\text { solved, } \\
\text { sum of } \\
\text { consti- } \\
\text { tuents } \\
\text { (milli- } \\
\text { grams } \\
\text { per } \\
\text { liter) }\end{array}$ & $\begin{array}{l}\text { Nitro- } \\
\text { gen, } \\
\mathrm{NO}_{2}+\mathrm{NO}_{3}, \\
\text { dis- } \\
\text { solved } \\
\text { (milli- } \\
\text { grams } \\
\text { per } \\
\text { liter } \\
\text { as } \mathrm{N} \text { ) }\end{array}$ & $\begin{array}{l}\text { Phos- } \\
\text { phorus, } \\
\text { ortho, } \\
\text { dis- } \\
\text { solved } \\
\text { (mflli- } \\
\text { grams } \\
\text { per } \\
\text { liter } \\
\text { as P) }\end{array}$ & $\begin{array}{l}\text { Iron, } \\
\text { dis- } \\
\text { solved } \\
\text { (micro- } \\
\text { grams } \\
\text { per } \\
1 \text { iter } \\
\text { as Fe) }\end{array}$ & $\begin{array}{l}\text { Manga- } \\
\text { nese, } \\
\text { dis- } \\
\text { solved } \\
\text { (micro- } \\
\text { grams } \\
\text { per } \\
1 \text { iter } \\
\text { as } M n \text { ) }\end{array}$ \\
\hline $25 S-01 E-24 D C D$ & 250 & 41 & 14 & 0.5 & 0.074 & 22 & 370 & 2.10 & 0.07 & 23 & 9 \\
\hline $25 \mathrm{~S}-01 \mathrm{~W}-07 \mathrm{BAA}$ & 210 & 66 & 18 & .4 & .043 & 18 & 370 & 6.30 & .04 & 7 & 44 \\
\hline $25 \mathrm{~S}-01 \mathrm{~W}-15 \mathrm{AAB}$ & 260 & 62 & 7.5 & .3 & .072 & 18 & 360 & 1.80 & .07 & 150 & 120 \\
\hline $25 S-01 W-24 C D C$ & 300 & 91 & 19 & .3 & .095 & 17 & 470 & $<0.10$ & $<.01$ & 4,300 & 120 \\
\hline $25 \mathrm{~S}-01 \mathrm{~W}-27 \mathrm{CCC}$ & 210 & 82 & 16 & .6 & .068 & 16 & 370 & .95 & .02 & $<3$ & 5 \\
\hline $25 \mathrm{~S}-01 \mathrm{~W}-30 \mathrm{ABB}$ & 190 & 60 & 47 & .5 & .087 & 15 & 420 & 21.0 & .02 & $<3$ & $<1$ \\
\hline $25 S-01 W-35 A A C$ & 290 & 170 & 25 & .5 & .038 & 21 & 600 & $<.10$ & $<.01$ & 130 & 75 \\
\hline $25 S-01 W-36 \mathrm{ACB}$ & 292 & 120 & 17 & .4 & .1 & 18 & 480 & 1.40 & .02 & 240 & 89 \\
\hline $25 \mathrm{~S}-02 \mathrm{~W}-02 \mathrm{BAA}$ & 250 & 78 & 60 & .4 & .052 & 23 & 480 & .23 & .02 & 190 & 210 \\
\hline $25 \mathrm{~S}-02 \mathrm{~W}-15 \mathrm{DDD}$ & 160 & 46 & 45 & .5 & .043 & 16 & 330 & 9.20 & .03 & 5 & 7 \\
\hline $25 \mathrm{~S}-02 \mathrm{~W}-17 \mathrm{ABB}$ & 180 & 97 & 110 & .5 & .081 & 18 & 530 & 9.50 & .02 & 25 & 8 \\
\hline $25 S-02 W-34 C C B$ & 260 & 340 & 580 & .8 & .34 & 15 & 1,700 & $<.10$ & .05 & 8 & 41 \\
\hline $25 S-03 W-02 B B C$ & 280 & 110 & 89 & .7 & .12 & 18 & 600 & 1.60 & $<.01$ & 350 & 110 \\
\hline $25 S-03 W-05 B A B$ & 200 & 80 & 200 & .7 & .088 & 16 & 630 & 2.40 & .03 & 13 & 7 \\
\hline $25 S-03 W-14 C C B$ & 200 & 190 & 510 & .5 & .31 & 16 & 1,270 & 3.00 & .03 & 21. & 5 \\
\hline $25 S-03 W-21 B A B$ & 230 & 26 & 41 & .4 & .11 & 23 & 360 & .89 & .04 & 4 & 190 \\
\hline $25 S-03 w-36 B B B$ & 200 & 72 & 200 & .6 & .088 & 18 & 630 & 1.20 & .11 & 10 & 4 \\
\hline $26 S-02 E-09 D A A$ & 190 &, 700 & 120 & .5 & .5 & 13 & 2,770 & $<.10$ & $<.01$ & 540 & 48 \\
\hline $26 \mathrm{~S}-01 \mathrm{E}-07 \mathrm{CBC}$ & 420 & 4.6 & 65 & .4 & .077 & 32 & 550 & $<.10$ & $<.01$ & 3,800 & 4,400 \\
\hline $26 \mathrm{~S}-01 \mathrm{E}-11 \mathrm{CDD}$ & 280 & 48 & 14 & .2 & .036 & 23 & 400 & 6.50 & .01 & 8 & 3 \\
\hline $26 S-01 E-17 A A B$ & 350 & 150 & 42 & .3 & .19 & 18 & 600 & .68 & .04 & 48 & 63 \\
\hline $26 S-01 E-19 A B D$ & 270 & 150 & 220 & .5 & .2 & 17 & 840 & 9.10 & .04 & 8 & 2 \\
\hline $26 S-01 E-21 B B A$ & 360 & 95 & 140 & .5 & .41 & 26 & 730 & .26 & .10 & 240 & 680 \\
\hline $26 S-01 E-31 A D C$ & 250 & 140 & 410 & .5 & .26 & 13 & 1,080 & .15 & $<.01$ & 200 & 24 \\
\hline $26 S-01 W-01 D A D$ & 270 & 89 & 34 & .3 & .17 & 16 & 460 & $<.10$ & .02 & 380 & 120 \\
\hline $26 S-01 W-05 B A B$ & 190 & 170 & 490 & .6 & .32 & 15 & 1,230 & .89 & .01 & 48 & 49 \\
\hline $26 \mathrm{~S}-01 \mathrm{~W}-15 \mathrm{BBB}$ & 210 & 250 & 630 & .5 & .4 & 15 & 1,570 & $<.10$ & .03 & 69 & 9 \\
\hline $26 \mathrm{~S}-01 \mathrm{~W}-18 \mathrm{AAA}$ & 230 & 230 & 410 & .6 & .24 & 16 & 1,240 & $<.10$ & $<.01$ & 1,100 & 430 \\
\hline $26 S-01 W-22 C B D$ & 200 & 220 & 400 & .5 & .18 & 18 & 1,160 & $<.10$ & $<.01$ & 550 & 690 \\
\hline $26 \mathrm{~S}-01 \mathrm{~W}-31 \mathrm{DAA}$ & 160 & 30 & 48 & .5 & .099 & 21 & 320 & 5.60 & .17 & 10 & 4 \\
\hline $26 \mathrm{~S}-02 \mathrm{~W}-04 \mathrm{BBD}$ & 250 & 170 & 310 & .5 & .16 & 16 & 1,000 & 1.30 & .11 & 38 & 400 \\
\hline $26 S-02 W-16 B B D$ & 300 & 24 & 23 & .3 & .074 & 24 & 400 & 2.20 & .15 & 4 & 6 \\
\hline $26 \mathrm{~S}-02 \mathrm{~W}-18 \mathrm{ADD}$ & 220 & 15 & 12 & .2 & .051 & 2.6 & 300 & 2.90 & .13 & 9 & 7 \\
\hline $26 S-02 W-33 C D D$ & 270 & 43 & 37 & .2 & .12 & 22 & 420 & 5.60 & .11 & $<3$ & 3 \\
\hline $26 \mathrm{~S}-03 \mathrm{~W}-08 \mathrm{DCB}$ & 260 & 880 & 130 & .3 & .14 & 21 & 1,690 & 6.30 & $<.01$ & 18 & 15 \\
\hline $26 S-03 W-10 D D B$ & 270 & 44 & 18 & .2 & .13 & 23 & 400 & 5.60 & .09 & 17 & 2 \\
\hline $26 s-03 w-30 C D C$ & 320 & 28 & 94 & .5 & .17 & 23 & 550 & 11.0 & $<.01$ & 110 & 2 \\
\hline $27 \mathrm{~S}-02 \mathrm{E}-13 \mathrm{CCC}$ & 270 &, 500 & 91 & .6 & .025 & 15 & 2,530 & .11 & $<.01$ & 630 & 4 \\
\hline $27 S-01 F-08 C C D$ & 260 & 100 & 150 & .5 & .23 & 16 & 660 & .73 & $<.01$ & 1,700 & 46 \\
\hline $27 \mathrm{~S}-01 \mathrm{E}-1$ 3DAC & 380 & 360 & 160 & .3 & .21 & 15 & 1,130 & .84 & $<.01$ & 51 & 87 \\
\hline $27 \mathrm{~S}-01 \mathrm{E}-18 \mathrm{CDD}$ & 320 & 190 & 240 & .3 & .32 & 19 & 990 & 2.00 & .03 & 13 & 12 \\
\hline $27 \mathrm{~S}-01 \mathrm{~W}-01 \mathrm{ADD}$ & 200 & 140 & 430 & .6 & .27 & 13 & 1,090 & .14 & .02 & 19 & 180 \\
\hline $27 \mathrm{~S}-01 \mathrm{~W}-03 \mathrm{DAA}$ & 140 & 120 & 350 & .5 & .11 & 8.2 & 870 & .20 & .02 & 35 & 28 \\
\hline $27 \mathrm{~S}-01 \mathrm{~W}-09 \mathrm{BCC}$ & 140 & 20 & 12 & .2 & .089 & 27 & 240 & 5.10 & .21 & 25 & 6 \\
\hline $27 \mathrm{~S}-01 \mathrm{~W}-12 \mathrm{DAA}$ & 170 & 150 & 240 & .4 & .15 & 15 & 750 & .84 & .01 & 13 & 150 \\
\hline $27 \mathrm{~S}-01 \mathrm{~W}-13 \mathrm{AAB}$ & 220 & 110 & 300 & .5 & .41 & 16 & 880 & 1.80 & $<.01$ & 42 & 69 \\
\hline $27 s-01 W-15 B D C$ & 170 & 43 & 61 & .3 & .14 & 26 & 400 & 9.00 & .16 & 78 & 12 \\
\hline $27 \mathrm{~S}-01 \mathrm{~W}-17 \mathrm{BCD}$ & 290 & 36 & 49 & .3 & .11 & 20 & 440 & 6.20 & .18 & in & 5 \\
\hline $27 \mathrm{~S}-01 \mathrm{~W}-21 \mathrm{CCC}$ & 270 & 31 & 43 & .3 & .14 & 23 & 430 & 7.10 & .18 & 50 & 1 \\
\hline $27 \mathrm{~S}-01 \mathrm{~W}-23 \mathrm{CDC}$ & 200 & 76 & 150 & .6 & .23 & 18 & 560 & $<.10$ & .09 & 570 & 170 \\
\hline
\end{tabular}


Table 15. Water-quality data for selected wells in Sedgwick County, August 1985 and February 1986-. Continued

PHYSICAL PROPERTIES AND INORGANIC CONSTITUENTS--Cont inued

\begin{tabular}{|c|c|c|c|c|c|c|c|c|c|c|c|}
\hline $\begin{array}{l}\text { Well number } \\
\text { (township-range- } \\
\text { section, plate } 1 \text { ) }\end{array}$ & $\begin{array}{l}\text { Alka- } \\
1 \text { inity, } \\
\text { (milli- } \\
\text { grams } \\
\text { per } \\
1 \text { iter } \\
\text { as } \\
\mathrm{CaCO}_{3} \text { ) }\end{array}$ & $\begin{array}{l}\text { Sulfate, } \\
\text { dis- } \\
\text { solved } \\
\text { (milli- } \\
\text { grams } \\
\text { per } \\
1 \text { iter } \\
\text { as } \mathrm{SO}_{4} \text { ) }\end{array}$ & $\begin{array}{l}\text { Chlo- } \\
\text { ride, } \\
\text { dis- } \\
\text { solved } \\
\text { (milli- } \\
\text { grams } \\
\text { per } \\
\text { liter } \\
\text { as } \mathrm{Cl} \text { ) }\end{array}$ & $\begin{array}{l}\text { Fluo- } \\
\text { ride, } \\
\text { dis- } \\
\text { solved } \\
\text { (milli- } \\
\text { grams } \\
\text { per } \\
\text { liter } \\
\text { as F) }\end{array}$ & $\begin{array}{l}\text { Bromide, } \\
\text { dis- } \\
\text { solved } \\
\text { (milli- } \\
\text { grams } \\
\text { per } \\
1 \text { iter } \\
\text { as Br) }\end{array}$ & $\begin{array}{l}\text { Silica, } \\
\text { dis- } \\
\text { solved } \\
\text { (milli- } \\
\text { grams } \\
\text { per } \\
1 \text { iter } \\
\text { as } \mathrm{SiO}_{2} \text { ) }\end{array}$ & $\begin{array}{l}\text { Sol ids, } \\
\text { sum of } \\
\text { const } \text { I- }^{-} \\
\text {tuents, } \\
\text { dis- } \\
\text { solved } \\
\text { (milli- } \\
\text { grams } \\
\text { per } \\
\text { liter) }\end{array}$ & $\begin{array}{l}\text { Nitro- } \\
\text { gen, } \\
\mathrm{NO}_{2}+\mathrm{NO}_{3} \\
\text { dis- } \\
\text { solved } \\
\text { (mill i- } \\
\text { grams } \\
\text { per } \\
1 \text { iter } \\
\text { as N) }\end{array}$ & $\begin{array}{l}\text { Phos- } \\
\text { phorus, } \\
\text { ortho, } \\
\text { dis- } \\
\text { solved } \\
\text { (milli- } \\
\text { grams } \\
\text { per } \\
\text { liter } \\
\text { as P) }\end{array}$ & $\begin{array}{l}\text { Iron, } \\
\text { dis- } \\
\text { solved } \\
\text { (micro- } \\
\text { grams } \\
\text { per } \\
1 \text { iter } \\
\text { as } \\
\text { Fe) }\end{array}$ & $\begin{array}{l}\text { Manga- } \\
\text { nese, } \\
\text { dis- } \\
\text { solved } \\
\text { (micro- } \\
\text { grams } \\
\text { per } \\
1 \text { iter } \\
\text { as } \mathrm{Mn} \text { ) }\end{array}$ \\
\hline $27 \mathrm{~S}-01 \mathrm{~W}-26 \mathrm{DDC}$ & 240 & 68 & 120 & 0.8 & 0.13 & 19 & 550 & $<0.10$ & 0.03 & 29 & 440 \\
\hline $27 \mathrm{~S}-01 \mathrm{~W}-27 \mathrm{BBD}$ & 290 & 45 & 76 & .4 & .096 & 21 & 520 & 6.10 & - & 20 & 4 \\
\hline $27 \mathrm{~S}-01 \mathrm{~W}-29 \mathrm{DBD}$ & 280 & 61 & 350 & .2 & .18 & 25 & 990 & 16.0 & .14 & 15 & 5 \\
\hline $27 \mathrm{~S}-01 \mathrm{~W}-33 \mathrm{AAA}$ & 220 & 28 & 46 & .4 & .1 & 22 & 370 & 2.80 & .18 & 9 & 1 \\
\hline $27 \mathrm{~S}-02 \mathrm{~W}-01 \mathrm{DBD}$ & 260 & 370 & 100 & .3 & .099 & 24 & 920 & .53 & .09 & 4 & 1 \\
\hline $27 \mathrm{~S}-02 \mathrm{~W}-10 \mathrm{ADA}$ & 300 & 34 & 28 & .3 & .092 & 22 & 420 & 4.50 & .09 & 5 & 2 \\
\hline $27 \mathrm{~S}-02 \mathrm{~W}-13 \mathrm{ABB}$ & 290 & 44 & 38 & .2 & .1 & 25 & 450 & 7.20 & .12 & 7 & 3 \\
\hline $27 \mathrm{~S}-02 \mathrm{~W}-32 \mathrm{BBB}$ & 320 & 85 & 27 & .3 & .058 & 22 & 480 & .98 & .06 & 4 & 2 \\
\hline $27 \mathrm{~S}-03 \mathrm{~W}-03 \mathrm{DCC}$ & 370 & 25 & 110 & .5 & .44 & 25 & 650 & 20.0 & -- & 29 & 2 \\
\hline $27 S-03 W-12 D C C$ & 290 & 71 & 180 & .6 & .67 & 20 & 710 & 16.0 & $<.01$ & 4 & 1 \\
\hline $27 S-03 W-31 D C D$ & 80 & 20 & 9.9 & .2 & .075 & 23 & 180 & 12.0 & .11 & 9 & 3 \\
\hline $27 \mathrm{~S}-04 \mathrm{~W}-12 \mathrm{CDC}$ & 220 & 600 & 180 & .6 & .21 & 17 & 1,340 & 8.90 & .01 & 6 & 5 \\
\hline $28 \mathrm{~S}-02 \mathrm{E}-01 \mathrm{DCA}$ & 200 & 1,000 & 69 & 1.0 & .083 & 5.6 & 1,690 & .17 & $<.01$ & 7 & 6 \\
\hline $28 \mathrm{~S}-02 \mathrm{E}-34 \mathrm{CAC}$ & 320 & 290 & 49 & .4 & .13 & 15 & 800 & 3.20 & $<.01$ & 330 & 5 \\
\hline $28 \mathrm{~S}-01 \mathrm{E}-05 \mathrm{BAB}$ & 360 & 210 & 320 & .5 & .21 & 17 & 1,160 & $<.10$ & $<.01$ & 650 & 240 \\
\hline $28 \mathrm{~S}-01 \mathrm{E}-07 \mathrm{DDD}$ & 320 & 180 & 260 & .6 & .17 & 18 & 1,000 & $<.10$ & $<.01$ & 420 & 540 \\
\hline $28 \mathrm{~S}-01 \mathrm{E}-17 \mathrm{DDB}$ & 200 & 88 & 220 & .8 & .21 & 14 & 690 & $<.10$ & .08 & 1,200 & 330 \\
\hline $28 \mathrm{~S}-01 \mathrm{E}-29 \mathrm{CBB}$ & 280 & 120 & 130 & .7 & .11 & 15 & 680 & $<.10$ & $<.01$ & 25 & 330 \\
\hline $28 \mathrm{~S}-01 \mathrm{~F}-31 \mathrm{CAB}$ & 100 & 160 & 150 & .2 & .24 & 25 & 600 & 8.50 & .06 & $<3$ & 8 \\
\hline $28 \mathrm{~S}-01 \mathrm{~W}-1 \mathrm{OCCB}$ & 220 & 24 & 27 & .3 & .068 & 22 & 330 & 4.90 & .11 & 5 & 6 \\
\hline $28 \mathrm{~S}-01 \mathrm{~W}-11 \mathrm{CBC}$ & 300 & 43 & 77 & .3 & .059 & 20 & 510 & .54 & .10 & 20 & 3 \\
\hline $28 \mathrm{~S}-01 \mathrm{~W}-17 \mathrm{ADD}$ & 140 & 230 & 28 & .4 & .072 & 27 & 550 & .23 & .10 & 53 & 34 \\
\hline $28 \mathrm{~S}-01 \mathrm{~W}-24 \mathrm{BBA}$ & 290 & 150 & 200 & .5 & .17 & 18 & 830 & $<.10$ & .08 & 20 & 230 \\
\hline $28 \mathrm{~S}-01 \mathrm{~W}-32 \mathrm{DDD}$ & 250 & 28 & 9.5 & .3 & .077 & 33 & 390 & 7.20 & .04 & 11 & 8 \\
\hline $28 \mathrm{~S}-02 \mathrm{~W}-11 \mathrm{CDD}$ & 240 & 1,100 & 130 & .3 & .2 & 20 & 2,000 & 3.00 & $<.01$ & 9 & 6 \\
\hline $28 \mathrm{~S}-02 \mathrm{~W}-21 \mathrm{CDD}$ & 130 & 21 & 18 & .3 & .075 & 26 & 230 & 5.10 & .18 & $<3$ & 4 \\
\hline $28 \mathrm{~S}-02 \mathrm{~W}-25 \mathrm{AAD}$ & 280 & 36 & 90 & .3 & .63 & 29 & 530 & 25.0 & .04 & 7 & 3 \\
\hline $28 \mathrm{~S}-02 \mathrm{~W}-32 \mathrm{AAA}$ & 210 & 650 & 190 & .3 & .2 & 16 & 1,400 & 5.30 & $<.01$ & 13 & 3 \\
\hline $28 \mathrm{~S}-03 \mathrm{~W}-01 \mathrm{ACC}$ & 360 & 39 & 32 & .3 & .31 & 23 & 490 & .89 & .01 & 18 & 2 \\
\hline $28 S-03 W-23 D D B$ & 180 & 110 & 160 & 3 & .12 & 21 & 600 & 4.30 & .04 & 7 & 4 \\
\hline $28 \mathrm{~S}-04 \mathrm{~W}-05 \mathrm{BCC}$ & 140 & 18 & 170 & .4 & .59 & 56 & 510 & 9.30 & .19 & $<3$ & 6 \\
\hline $28 \mathrm{~S}-04 \mathrm{~W}-15 \mathrm{BCC}$ & 230 & 51 & 9.6 & .4 & .054 & 16 & 360 & 12.0 & .10 & 29 & 1 \\
\hline $28 \mathrm{~S}-04 \mathrm{~W}-20 \mathrm{ABA}$ & 120 & 870 & 38 & .4 & .075 & 18 & 1,370 & 4.30 & $<.01$ & 12 & 4 \\
\hline $28 \mathrm{~S}-04 \mathrm{~W}-20 \mathrm{ABD}$ & 120 & 830 & 42 & .3 & .079 & 17 & 1,390 & 4.40 & $<.01$ & 510 & 5 \\
\hline $28 \mathrm{~S}-04 \mathrm{~N}-35 \mathrm{ABD}$ & 190 & 470 & 74 & .4 & .098 & 16 & 920 & .33 & $<.01$ & 510 & 600 \\
\hline $29 \mathrm{~S}-02 \mathrm{E}-18 \mathrm{CBC}$ & 260 & 27 & 20 & .2 & .1 & 25 & 390 & 12.0 & .02 & 9 & 7 \\
\hline $29 S-01 F-03 D C C$ & 310 & 74 & 80 & .6 & .18 & 18 & 570 & 5.00 & .03 & 5 & 4 \\
\hline $29 \mathrm{~S}-01 \mathrm{E}-05 \mathrm{CAA}$ & 290 & 160 & 100 & .6 & .19 & 15 & 660 & .36 & $<.01$ & 320 & 170 \\
\hline $29 \mathrm{~S}-01 \mathrm{E}-14 \mathrm{DCC}$ & 280 & 130 & 71 & .7 & .084 & 16 & 600 & 1.20 & .04 & 5 & 180 \\
\hline $29 \mathrm{~S}-01 \mathrm{E}-21 \mathrm{CBC}$ & 250 & 64 & 14 & .4 & .071 & 16 & 380 & $<.10$ & $<.01$ & 560 & 41 \\
\hline $29 \mathrm{~S}-01 \mathrm{E}-23 \mathrm{CCC}$ & 220 & 76 & 28 & .6 & .036 & 15 & 390 & .31 & .01 & 50 & 220 \\
\hline $29 \mathrm{~S}-01 \varepsilon-31 \mathrm{BAB}$ & 190 & 46 & 52 & .3 & .17 & 23 & 360 & 4.50 & .11 & 29 & 4 \\
\hline $29 \mathrm{~S}-01 \mathrm{E}-34 \mathrm{CCB}$ & 300 & 130 & 32 & .6 & - & 13 & 550 & 5.10 & $<.01$ & 72 & 140 \\
\hline $29 \mathrm{~S}-01 \mathrm{E}-36 \mathrm{CCn}$ & 290 & 84 & 47 & .6 & .039 & 16 & 480 & .56 & .03 & 13 & 440 \\
\hline $29 \mathrm{~S}-01 \mathrm{~W}-06 \mathrm{DAA}$ & 92 & 270 & 64 & .2 & .095 & 22 & 620 & 9.40 & .02 & 27 & 4 \\
\hline $29 \mathrm{~S}-01 \mathrm{w}-11 \mathrm{ADD}$ & 190 & 23 & 13 & .3 & .046 & 25 & 270 & 1.70 & .14 & 6 & $<1$ \\
\hline $29 \mathrm{~S}-01 \mathrm{w}-27 \mathrm{BBB}$ & 240 & 56 & 20 & .3 & .14 & 24 & 370 & 11.0 & .13 & 8 & 3 \\
\hline $29 \mathrm{~S}-02 \mathrm{~W}-23 \mathrm{DDA}$ & 210 & 53 & 43 & .5 & .091 & 25 & 390 & 6.60 & .11 & 16 & 4 \\
\hline $29 \mathrm{~S}-03 \mathrm{~W}-09 \mathrm{ABA}$ & 200 & 77 & 13 & .5 & .061 & 18 & 350 & 1.30 & .07 & 16 & 35 \\
\hline $29 \mathrm{~S}-04 \mathrm{~W}-16 \mathrm{BCC}$ & 250 & 83 & 33 & .4 & .11 & 19 & 480 & 7.20 & $<. n 1$ & 5 & $<1$ \\
\hline $29 S-04 W-35 B D C$ & 190 & 51 & 51 & .2 & .12 & 19 & 390 & 15.0 & .02 & 5 & 1 \\
\hline
\end{tabular}


Table 15. Water-quality data for selected wells in Sedgwick County, August 1985 and February 1986-Continued

ORGANIC CONSTITUENTS - HERRICIDES

\begin{tabular}{|c|c|c|c|c|c|c|c|c|c|}
\hline $\begin{array}{l}\text { Well number } \\
\text { (township-range- } \\
\text { section, plate } 1 \text { ) }\end{array}$ & $\begin{array}{l}\text { Ame- } \\
\text { tryne, } \\
\text { total } \\
\text { (micro- } \\
\text { grams } \\
\text { per } \\
1 \text { it er) }\end{array}$ & $\begin{array}{l}\text { Atra- } \\
\text { zine, } \\
\text { total } \\
\text { (micro- } \\
\text { grams } \\
\text { per } \\
\text { liter) }\end{array}$ & $\begin{array}{l}\text { Cyan- } \\
\text { azine, } \\
\text { total } \\
\text { (micro- } \\
\text { grams } \\
\text { per } \\
1 \text { iter) }\end{array}$ & $\begin{array}{l}\text { Metola- } \\
\text { chlor, } \\
\text { total } \\
\text { (micro- } \\
\text { grams } \\
\text { per } \\
\text { liter) }\end{array}$ & $\begin{array}{l}\text { Prome- } \\
\text { tone, } \\
\text { total } \\
\text { (micro- } \\
\text { grams } \\
\text { per } \\
1 \text { iter) }\end{array}$ & $\begin{array}{l}\text { Prome- } \\
\text { tryne, } \\
\text { total } \\
\text { (micro- } \\
\text { grams } \\
\text { per } \\
1 \text { 1ter) }\end{array}$ & $\begin{array}{l}\text { Pro- } \\
\text { pazine, } \\
\text { total } \\
\text { (micro- } \\
\text { grams } \\
\text { per } \\
1 \text { iter) }\end{array}$ & $\begin{array}{l}\text { Sima- } \\
\text { zine, } \\
\text { total } \\
\text { (micro- } \\
\text { grams } \\
\text { per } \\
\text { liter) }\end{array}$ & $\begin{array}{l}\text { Sime- } \\
\text { tryne, } \\
\text { total } \\
\text { (micro- } \\
\text { grams } \\
\text { per } \\
\text { liter) }\end{array}$ \\
\hline $\begin{array}{l}25 s-01 W-07 B A A \\
25 s-01 W-30 A B B \\
25 s-02 w-15 D D D \\
25 S-03 w-05 B A B \\
25 S-03 w-14 C C B\end{array}$ & $\begin{array}{l}<0.1 \\
<.1 \\
<.1 \\
<.1 \\
<.1\end{array}$ & $\begin{array}{r}0.3 \\
.2 \\
.4 \\
<.1 \\
<.1\end{array}$ & $\begin{array}{l}<0.1 \\
<.1 \\
<.1 \\
<.1 \\
<.1\end{array}$ & $\begin{array}{l}6 \\
-- \\
--\end{array}$ & $\begin{array}{l}<0.1 \\
<.1 \\
<.1 \\
<.1 \\
<.1\end{array}$ & $\begin{array}{l}<0.1 \\
<.1 \\
<.1 \\
<.1 \\
<.1\end{array}$ & $\begin{array}{l}<0.1 \\
<.1 \\
<.1 \\
<.1 \\
<.1\end{array}$ & $\begin{array}{l}<0.1 \\
<.1 \\
<.1 \\
<.1 \\
<.1\end{array}$ & $\begin{array}{l}<0.1 \\
<.1 \\
<.1 \\
<.1 \\
<.1\end{array}$ \\
\hline $\begin{array}{l}25 S-03 W-36 B B B \\
26 S-01 W-18 A A A \\
26 S-02 W-16 B B D \\
27 S-01 W-03 D A A \\
27 S-02 W-01 D B D\end{array}$ & $\begin{array}{l}<.1 \\
<.1 \\
<.1 \\
<.1 \\
<.1\end{array}$ & $\begin{array}{l}<.1 \\
<.1 \\
<.1 \\
.2 \\
<.1\end{array}$ & $\begin{array}{l}<.1 \\
<.1 \\
<.1 \\
<.1 \\
<.1\end{array}$ & $\begin{array}{l}-- \\
-- \\
- \\
--\end{array}$ & $\begin{array}{l}<.1 \\
<.1 \\
<.1 \\
<.1 \\
<.1\end{array}$ & $\begin{array}{l}<.1 \\
<.1 \\
<.1 \\
<.1 \\
<.1\end{array}$ & $\begin{array}{l}<.1 \\
<.1 \\
<.1 \\
.2 \\
<.1\end{array}$ & $\begin{array}{l}<.1 \\
<.1 \\
<.1 \\
.1 \\
<.1\end{array}$ & $\begin{array}{l}<.1 \\
<.1 \\
<.1 \\
<.1 \\
<.1\end{array}$ \\
\hline $\begin{array}{l}27 S-02 W-32 B B B \\
28 S-02 W-25 A A D \\
28 S-04 W-05 B C C \\
28 S-04 W-35 A B D \\
29 S-01 E-23 C C C\end{array}$ & $\begin{array}{l}<.1 \\
<.1 \\
<.1 \\
<.1 \\
<.1\end{array}$ & $\begin{array}{l}<.1 \\
<.1 \\
<.1 \\
<.1 \\
<.1\end{array}$ & $\begin{array}{l}<.1 \\
<.1 \\
<.1 \\
<.1 \\
<.1\end{array}$ & $\begin{array}{l}-- \\
-- \\
-- \\
--\end{array}$ & $\begin{array}{l}<.1 \\
<.1 \\
<.1 \\
<.1 \\
<.1\end{array}$ & $\begin{array}{l}<.1 \\
<.1 \\
<.1 \\
<.1 \\
<.1\end{array}$ & $\begin{array}{l}<.1 \\
<.1 \\
<.1 \\
<.1 \\
<.1\end{array}$ & $\begin{array}{l}<.1 \\
<.1 \\
<.1 \\
<.1 \\
<.1\end{array}$ & $\begin{array}{l}<.1 \\
<.1 \\
<.1 \\
<.1 \\
<.1\end{array}$ \\
\hline $\begin{array}{l}29 S-01 E-31 B A B \\
29 S-01 W-11 A D D \\
29 S-02 W-23 D D A \\
29 S-03 W-09 A B A\end{array}$ & $\begin{array}{l}<.1 \\
<.1 \\
<.1 \\
<.1\end{array}$ & $\begin{array}{l}.1 \\
<.1 \\
<.1 \\
<.1\end{array}$ & $\begin{array}{l}<.1 \\
<.1 \\
<.1 \\
<.1\end{array}$ & $\begin{array}{l}- \\
-- \\
-\end{array}$ & $\begin{array}{l}<.1 \\
<.1 \\
<.1 \\
<.1\end{array}$ & $\begin{array}{l}<.1 \\
<.1 \\
<.1 \\
<.1\end{array}$ & $\begin{array}{l}<.1 \\
<.1 \\
<.1 \\
<.1\end{array}$ & $\begin{array}{l}<.1 \\
<.1 \\
<.1 \\
<.1\end{array}$ & $\begin{array}{l}<.1 \\
<.1 \\
<.1 \\
<.1\end{array}$ \\
\hline
\end{tabular}

ORGANIC CONSTITUENTS - VOLATILE ORGANIC COMPOUNDS

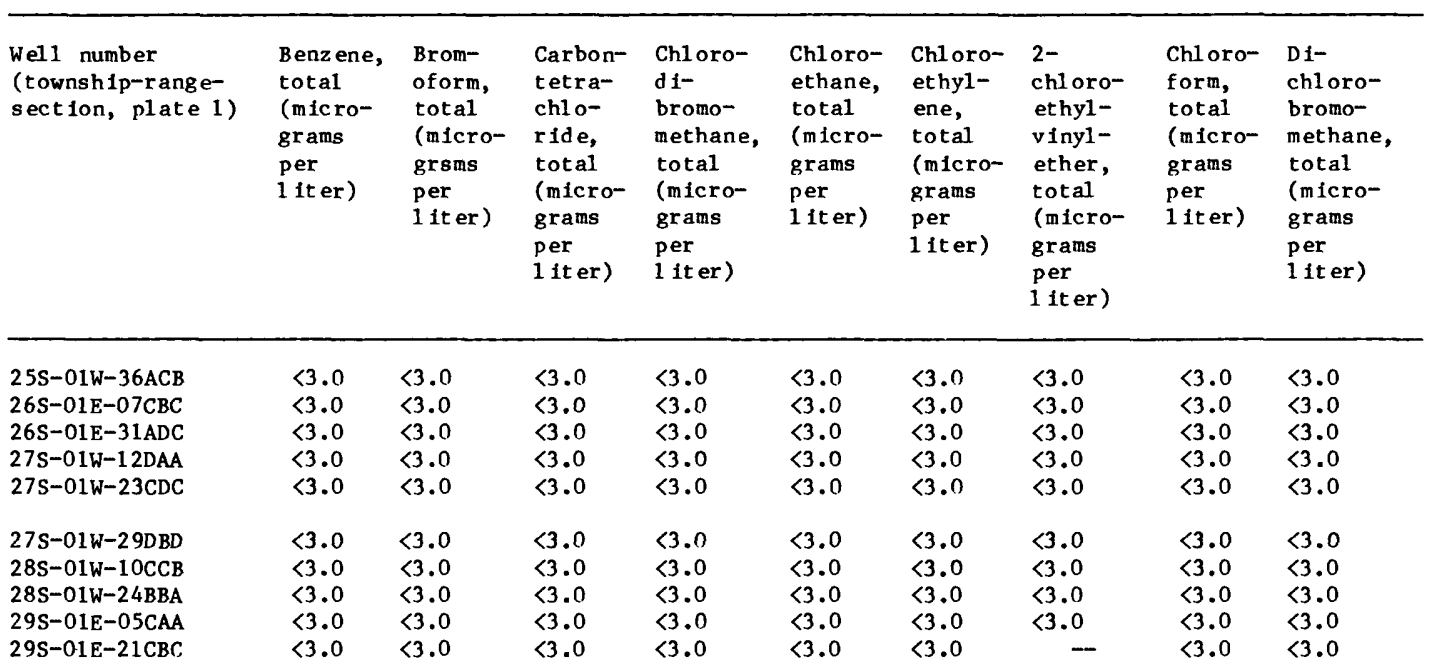


Table 15. Water-quality data for selected wells in Sedgwick County, August 1985 and February 1986-Continued

ORGANIC CONSTITUENTS - VOLATILE ORGANIC COMPOUNDS--Cont inued

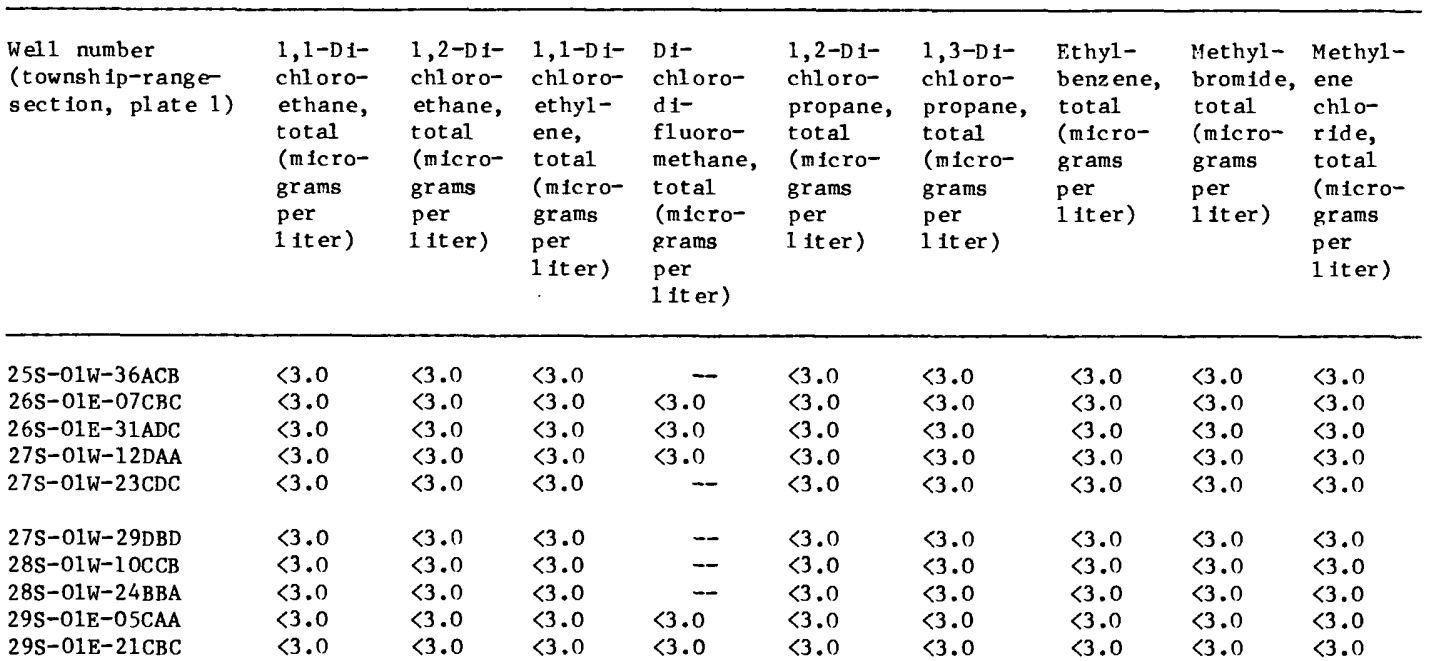

\begin{tabular}{|c|c|c|c|c|c|c|c|c|}
\hline $\begin{array}{l}\text { Wel1 number } \\
\text { (township-range- } \\
\text { section, plate } 1 \text { ) }\end{array}$ & $\begin{array}{l}1,1,2,2 \\
\text { tetra- } \\
\text { chloro- } \\
\text { ethane, } \\
\text { total } \\
\text { (micro- } \\
\text { grams } \\
\text { per } \\
1 \text { iter) }\end{array}$ & $\begin{array}{l}\text { Tetra- } \\
\text { chloro- } \\
\text { ethyl- } \\
\text { ene, } \\
\text { total } \\
\text { (micro- } \\
\text { grams } \\
\text { per } \\
\text { liter) }\end{array}$ & $\begin{array}{l}\text { Toluene, } \\
\text { total } \\
\text { (micro- } \\
\text { grams } \\
\text { per } \\
1 \text { 1t er) }\end{array}$ & $\begin{array}{l}1,1,1- \\
\text { Tri- } \\
\text { chloro- } \\
\text { ethane, } \\
\text { total } \\
\text { (micro- } \\
\text { grams } \\
\text { per } \\
\text { liter) }\end{array}$ & $\begin{array}{l}1,1,2- \\
\text { Tri- } \\
\text { chloro- } \\
\text { ethane, } \\
\text { total } \\
\text { (micro- } \\
\text { grams } \\
\text { per } \\
1 \text { it er) }\end{array}$ & $\begin{array}{l}\text { Tri- } \\
\text { ch1oro- } \\
\text { ethyl- } \\
\text { ene, } \\
\text { total } \\
\text { (micro- } \\
\text { grams } \\
\text { per } \\
\text { liter) }\end{array}$ & $\begin{array}{l}\text { Tri- } \\
\text { chl oro- } \\
\text { flouro- } \\
\text { methane, } \\
\text { total } \\
\text { (micro- } \\
\text { grams } \\
\text { per } \\
1 \text { it er) }\end{array}$ & $\begin{array}{l}\text { V inyl } \\
\text { chlo- } \\
\text { ride, } \\
\text { total } \\
\text { (micro- } \\
\text { grams } \\
\text { per } \\
\text { liter) }\end{array}$ \\
\hline $25 S-01 W-36 A C B$ & $<3.0$ & $<3.0$ & $<3.0$ & $<3.0$ & $<3.0$ & $<3.0$ & $<3.0$ & $<3.0$ \\
\hline $26 \mathrm{~S}-01 \mathrm{E}-07 \mathrm{CBC}$ & $<3.0$ & $<3.0$ & $<3.0$ & $<3.0$ & $<3.0$ & $<3.0$ & $<3.0$ & $<3.0$ \\
\hline $26 \mathrm{~S}-01 \mathrm{E}-31 \mathrm{ADC}$ & $<3.0$ & $<3.0$ & $<3.0$ & $<3.0$ & $<3.0$ & $<3.0$ & $<3.0$ & $<3.0$ \\
\hline $27 \mathrm{~S}-01 \mathrm{~W}-12 \mathrm{DAA}$ & $<3.0$ & $<3.0$ & $<3.0$ & $<3.0$ & $<3.0$ & $<3.0$ & $<3.0$ & $<3.0$ \\
\hline $27 \mathrm{~S}-01 \mathrm{w}-23 \mathrm{CDC}$ & $<3.0$ & $<3.0$ & $<3.0$ & $<3.0$ & $<3.0$ & $<3.0$ & $<3.0$ & $<3.0$ \\
\hline $27 S-01 W-29 D B D$ & $<3.0$ & $<3.0$ & $<3.0$ & $<3.0$ & $<3.0$ & $<3.0$ & $<3.0$ & $<3.0$ \\
\hline $28 \mathrm{~S}-01 \mathrm{~W}-10 \mathrm{CCB}$ & $<3.0$ & $<3.0$ & $<3.0$ & $<3.0$ & $<3.0$ & 8.2 & $<3.0$ & $<3.0$ \\
\hline $28 S-01 W-24 B B A$ & $<3.0$ & $<3.0$ & $<3.0$ & $<3.0$ & $<3.0$ & $<3.0$ & $<3.0$ & $<3.0$ \\
\hline $29 \mathrm{~S}-01 \mathrm{E}-05 \mathrm{CAA}$ & $<3.0$ & $<3.0$ & $<3.0$ & $<3.0$ & $<3.0$ & $<3.0$ & $<3.0$ & $<3.0$ \\
\hline $29 \mathrm{~S}-01 \mathrm{E}-21 \mathrm{CBC}$ & $<3.0$ & $<3.0$ & $<3.0$ & $<3.0$ & $<3.0$ & $<3.0$ & $<3.0$ & $<3.0$ \\
\hline
\end{tabular}

1 Water use: D, domest ic; I, Irrigat ion; L\&G, 1 awn and garden; P, publ ic supply; S, stock.

2 Geologic source: Qal, Holocene alluvium and Wisconsin terrace deposits; Q1, 1oess deposits; Qc, colluvium; Qt, Illinoian terrace deposits; Qu, lower P1e1stocene (undifferent lated pre-Ill inolan) deposits; QT, und ifferent lated lower P1 eistocene and P1 locene deposits; Pn, Ninnescah Shale; Pw, Wellington Formation.

3 Samples analyzed for selected herbicides.

4 Samples analyzed for selected vol at 11 e organic compounds. 
the Burrton oilfield adjacent to the Arkansas River, about 2 miles upstream of Sedgwick County in Reno County, could have contributed brine to the Arkansas River, which subsequently infiltrated into the alluvium sometime in the past. Water samples collected from the Arkansas River during this investigation (see stream water-quality data, table 11) did not have sodium:chloride ratios that indicate contamination by oilfield brine.

A sodium:chloride ratio less than 0.60 was detected in water from well 26S-01E-31ADC, which is adjacent to the Little Arkansas River in north Wichita. There are oilfield activities upgradient (north) of this well. South of Wichita, sodium:chloride ratios less than 0.60 are present in wells 28S-01E-31CAD and 29S-01E-03DCC. These wells are in alluvium and terrace deposits of Wisconsin to Holocene age in an area known to be contaminated by oilfield activities in the Gladys oilfield, which is just north of Haysville (Whittemore, 1982). Well 28S-04W-05BCC, just north of Cheney, is adjacent to an oilfield and had a sodium:chloride ratio that was less than 0.60. Other wells with sodium:chloride ratios less than 0.60 were in areas with no apparent oilfield activities (27S-03W-03DCC, 27S-03W12DCC, 28S-02E-34CAC, 28S-02W-25AAD, and 28S-03W-23DDB).

\section{Nitrogen}

Nitrogen can be introduced into ground water by the leaching of fertilizers, by sewage disposal (septic fields and infiltration of sewagetreatment plant effluent), and by surface runoff with fertilizer residues or animal wastes entering improperly constructed wells. Nitriteplus-nitrate as nitrogen concentrations that exceed $10 \mathrm{mg} / \mathrm{L}$, the water-quality criterion for nitrate as nitrogen (U.S. Environmental Protection Agency, 1986c) were detected in 11 wells (25S-01W-30ABB, 26S-03W-30CDC, 27S01W-29DBD, 27S-03W-03DCC, 27S-03W12DCC, 27S-03W-31 DCD, 28S-02W-25AAD, 28S-04W-15BCB, 29S-02E-18CBC, 29S-01W27BBB, and 29S-04W-35BDC). The criterion for nitrate as nitrogen was used because nitrite is unstable and is oxidized to nitrate and because the criteria for nitrite is more strict than for nitrate. Exceedences of the nitrate-as-nitrogen criterion occur randomly throughout the county and probably result from local sources of contamination, such as surface runoff into improperly constructed wells or infiltration from septic fields.

\section{Iron and manganese}

Concentrations of iron that exceed the water-quality criterion of $300 \mathrm{\mu g} / \mathrm{L}$ (U.S. Environmental Protection Agency, 1986b) were detected in samples from 18 wells (see table 15). These wells are scattered randomly throughout the county, and the large concentrations of iron may be due to corroded steel or galvanized well casings. Iron causes no significant health effects but can be objectionable because of taste, staining of laundry and porcelain fixtures, and deposits in plumbing.

Concentrations of manganese that exceed the water-quality criterion of $50 \mu \mathrm{g} / \mathrm{L}$ (U.S. Environmental Protection Agency, 1986b) were detected in 31 wells. All but one of the wells are located in alluvium or terrace deposits. This indicates that the manganese probably is derived from organic matter in soil and then is leached by percolation of precipitation through the unconsolidated sand and gravel into the ground water. Manganese produces no significant health effects but can be objectionable because of taste, staining of porcelain fixtures, and deposits in plumbing.

\section{Herbicides}

Water-quality samples from 19 wells in alluvium and terrace deposits of the Ninnescah and Arkansas River valleys were analyzed for selected herbicides (ametryne, atrazine, cyanazine, metolachlor, prometone, prometryne, propazine, simazine, and simetryne) (see table 15). None of the herbicides were detected in water samples from the four wells in the Ninnescah River valley. However, of the 15 wells sampled in the Arkansas River valley, herbicides were detected in five. Atrazine (0.3 $\mu \mathrm{g} / \mathrm{L})$ and metolachlor $(6 \mu \mathrm{g} / \mathrm{L})$ were detected in well 25S-01W-07BAA. Atrazine also was detected in wells $25 \mathrm{~S}-01 \mathrm{~W}-30 \mathrm{ABB}(0.2 \mu \mathrm{g} / \mathrm{L})$, 25S-02W-15DDD $(0.4 \mu \mathrm{g} / \mathrm{L})$, and 29S-01E$31 \mathrm{BAB}(0.1 \mu \mathrm{g} / \mathrm{L})$. Atrazine $(0.2 \mu \mathrm{g} / \mathrm{L})$, propazine $(0.2 \mu \mathrm{g} / \mathrm{L})$, and simazine $(0.1 \mu \mathrm{g} / \mathrm{L})$ were detected in well 27S-01W-03DAA. These herbicides may have entered the ground water either by being leached from the surface, through runoff into 
improperly constructed wells, or, if the process of chemigation is practiced (chemicals applied in irrigation water), they may have been siphoned down the well.

The uses of atrazine and propazine and the implications of their occurrence in water were discussed previously in the "Results of WaterQuality Reconnaissance" part of the "Impoundment" section. The U.S. Environmental Protection Agency has issued a lifetime health advisory level of $3 \mu \mathrm{g} / \mathrm{L}$ for atrazine and $14 \mu \mathrm{g} / \mathrm{L}$ for propazine (U.S. Environmental Protection Agency, written commun., August and September 1987).

Metolachlor is used as a preemergent and preplant incorporated weed control in corn, soybeans, and grain sorghum. It is soluble in water at $530 \mathrm{mg} / \mathrm{L}$ and has a half-life in soil of from 15 to 50 days. The U.S. Environmental Protection Agency has issued a lifetime health advisory level of $10.0 \mu \mathrm{g} / \mathrm{L}$ for metolachlor (U.S. Environmental Protection Agency, written commun., August 1987).

Simazine is is used to control most annual broadleaf weeds and grasses in corn, alfalfa, fruits, nursery stock, and turf-grass production. It is soluble in water at $3.5 \mathrm{mg} / \mathrm{L}$ and persists in soil for 1 year or longer. The U.S. Environmental Protection Agency has issued a lifetime health advisory level of $35 \mu \mathrm{g} / \mathrm{L}$ for simazine (U.S. Environmental Protection Agency, written commun., August 1987).

Although the detected concentrations of these herbicides were quite small, they may pose health threats because of the mutagens and degradation products that they produce, the possible synergistic effects that might result from the occurrence of more than one of the herbicides, and the widespread nature of herbicide application. Many other pesticides (both insecticides and herbicides) probably are used in Sedgwick County. The insecticide chlordane has been detected in tissue of bottomfeeding fish in the Arkansas River at Wichita (Fromm and Daley, 1986).

\section{Volatile organic compounds}

Analysis of volatile organic compounds (also known as purgeable organic compounds) was made on water samples from 10 wells in the Little Arkansas and Arkansas River valleys (see table 15). Volatile organic compounds are ingredients in many household, commercial, and industrial products, including spot removers, drain openers, solvents, and degreasers; and may enter ground water through septic fields, spills, leaks, or disposal from industrial processes. The volatile organic compound trichloroethylene was detected in well 28S-01W-10CBB at a concentration of $8.2 \mu \mathrm{g} / \mathrm{L}$; the water-quality criterion is $27 \mu \mathrm{g} / \mathrm{L}$ (U.S. Environmental Protection Agency, 1986a). Trichloroethylene is a suspected carcinogen and can cause centralnervous-system depression and heart damage.

Volatile organic compounds also have been detected by the U.S. Geological Survey (Hart and Spruill, 1988), the Kansas Department of Health and Environment (Wichita-Eagle Beacon, June 11, 1985; Sept. 9, 1985; Jan. 15, 1986), and the U.S. Environmental Protection Agency (WichitaEagle Beacon, Jan. 18, 1985). Although volatile organic compounds have been detected in ground water at several sites in Sedgwick County, the contaminated areas are localized and do not represent a widespread water-quality problem.

\section{Statistical Summary of Historic Water- Quality Data for Selected Wells}

There are several wells in Sedgwick County where water-quality data have been collected for a relatively long time, generally during the last 30 years. Statistical summaries of water-quality data for six of these wells are presented in table 16. Five of the wells are public-supply wells (Valley Center, Wichita, Park City, Goddard, and Clearwater). All of the wells produce water from unconsolidated deposits ranging in age from Pliocene to Holocene.

The Valley Center public-supply well 5 (25S-01W-36ACB) is 52.0 feet deep and yields water from alluvium of the Little Arkansas River valley. Water from this well is a calcium bicarbonate type, with a median dissolved-solids concentration of $524 \mathrm{mg} / \mathrm{L}$. The water has a median concentration of hardness as calcium carbonate of $380 \mathrm{mg} / \mathrm{L}$. Concentrations of manganese (median concentration, $130 \mu \mathrm{g} / \mathrm{L}$ ) 
Wellington Formation generally has hardness as calcium carbonate approaching or exceeding $1,000 \mathrm{mg} / \mathrm{L}$ (most of which is noncarbonate hardness) in calcium sulfate type water.

Water from wells in the Ninnescah Shale of Permian age, which occurs in the western part of the county, generally is not as mineralized as water from the Wellington Formation because the Ninnescah Shale does not contain as many readily soluble minerals and because the occurrence of unconsolidated loess, colluvium, or lower Pleistocene (undifferentiated pre-Illinoian age) deposits over the Ninnescah Shale improves recharge conditions and probably allows dilution of water in the bedrock (Lane and Miller, 1965a). Shallow wells in the upper weathered part of the Ninnescah Shale generally yield calcium bicarbonate water, with dissolved-solids concentrations less than $1,000 \mathrm{mg} / \mathrm{L}$. Mineralization of water increases with depth in the Ninnescah Shale, and where thin beds of gypsum are encountered, the water is a calcium sulfate type, with concentrations of dissolved solids often exceeding $1,000 \mathrm{mg} / \mathrm{L}$. Water samples from the Ninnescah Shale had from 5 to $1,000 \mathrm{mg} / \mathrm{L}$ of hardness as calcium carbonate. The largest concentrations of hardness occur primarily as noncarbonate hardness in calcium sulfate type water.

Unconsolidated deposits ranging in age from Pliocene to Holocene generally are the best sources of ground water in the county with respect to both the quantity and quality of water available. These deposits of clay, silt, sand, and gravel are erosional remnants that have few readily soluble minerals; they are recharged rapidly by precipitation and transmit ground water at a faster rate than bedrock. However, unconsolidated deposits generally are more susceptible to contamination.

Lower Pleistocene (undifferentiated preIllinoian age) deposits that occur in upland areas north of the Ninnescah River yield calcium bicarbonate type water, with less than $500 \mathrm{mg} / \mathrm{L}$ dissolved solids. Hardness as calcium carbonate in water samples ranges from 130 to $360 \mathrm{mg} / \mathrm{L}$. Terrace deposits of Illinoian age that occur along the western side of the Arkansas River valley, in the vicinity of Clearwater, and in a small buried valley in the southwest corner of the county generally yield calcium bicarbonate water, with less than $500 \mathrm{mg} / \mathrm{L}$ dissolved solids. Northwest of Wichita, Illinoian terrace deposits occur over unconsolidated lower Pleistocene and Pliocene and deposits (Lane and Miller, 1965a). Along the eastern edge of the Illinoian terrace deposits, generally between Cowskin Creek and Big Slough Creek from about 6 miles southeast of Mount Hope to where Cowskin Creek intersects the Wichita-Valley Center floodway, there is an area where calcium bicarbonate water from the Illinoian terrace deposits is mixing with sodium chloride water from the Arkansas River terrace and alluvial deposits of Holocene age. In this mixing zone, water types include calcium bicarbonate, calcium sodium bicarbonate, calcium sodium chloride, sodium bicarbonate, sodium bicarbonate chloride, and sodium chloride. In this area, concentrations of dissolved solids are less than $1,000 \mathrm{mg} / \mathrm{L}$ and usually less than $500 \mathrm{mg} / \mathrm{L}$. Hardness as calcium carbonate in water samples from Illinoian terrace deposits ranges from 83 to $480 \mathrm{mg} / \mathrm{L}$.

Alluvium and terrace deposits of Wisconsin to Holocene age occur in the Ninnescah, Little Arkansas, and Arkansas River valleys. Older unconsolidated deposits of undifferentiated early Pleistocene and Pliocene age occur at the basal part of the valley-fill deposits northwest of Wichita (Lane and Miller, 1965a). Water-quality data are limited for the alluvium and terrace deposits of the Ninnescah River. The Ninnescah River is a gaining stream throughout its reach, and water in the alluvium may be similar to that in adjacent bedrock, probably calcium sulfate or calcium bicarbonate type water with less than $1,000 \mathrm{mg} / \mathrm{L}$ dissolved solids. Large-capacity wells could induce infiltration of stream water into the alluvium and yield sodium chloride type water with less than $1,000 \mathrm{mg} / \mathrm{L}$ dissolved solids.

Water in alluvium and terrace deposits of Wisconsin to Holocene age in the Little Arkansas River valley north of Wichita generally is a calcium bicarbonate type, with less than $500 \mathrm{mg} / \mathrm{L}$ dissolved solids although concentrations of dissolved solids can exceed 500 $\mathrm{mg} / \mathrm{L}$. In northern Wichita, the Little Arkansas River alluvium and terrace deposits contain sodium calcium chloride bicarbonate type water, with concentrations of dissolved solids exceeding $500 \mathrm{mg} / \mathrm{L}$, or sodium chloride type water, with concentrations of dissolved solids exceeding 
$1,000 \mathrm{mg} / \mathrm{L}$. The Little Arkansas River is the primary drain for ground water in alluvium and terrace deposits in northern Sedgwick County. Sodium chloride type water from the Arkansas River has moved through the alluvium to areas adjacent to the Little Arkansas River in northern Wichita.

Sodium chloride type water generally is present in alluvium and terrace deposits of Wisconsin to Holocene age that occur along the west side of the Arkansas River in Sedgwick County north of the confluence of the Arkansas River and the Wichita-Valley Center floodway. The source of this sodium chloride type water is the Arkansas River. From Mount Hope to Wichita, concentrations of dissolved solids generally exceed $1,000 \mathrm{mg} / \mathrm{L}$. Concentrations of dissolved solids generally are less than 1,000 $\mathrm{mg} / \mathrm{L}$ from north Wichita to the confluence of the Arkansas River and the Wichita-Valley Center floodway near Derby.

A narrow band (probably less than 2 miles wide) of sodium chloride type water, with dissolved-solids concentrations exceeding 1,000 $\mathrm{mg} / \mathrm{L}$, occurs along the east side of the Arkansas River north of Wichita. However, most of the area of alluvium and terrace deposits between the Arkansas and Little Arkansas Rivers north of Wichita has calcium bicarbonate type water, with less than $500 \mathrm{mg} / \mathrm{L}$ dissolved solids.

South of Wichita, alluvium and terrace deposits of Wisconsin to Holocene age contain calcium bicarbonate water, with concentrations of dissolved solids less than $1,000 \mathrm{mg} / \mathrm{L}$ and sometimes less than $500 \mathrm{mg} / \mathrm{L}$. Although sodium chloride water was not observed in wells sampled within one-half mile of the Arkansas River south of Wichita, primarily because the river is gaining, large-capacity wells adjacent to the river could induce the infiltration of saline river water and yield sodium chloride water. Water samples from alluvium and terrace deposits of Wisconsin to Holocene age had hardness as calcium carbonate ranging from 27 to $560 \mathrm{mg} / \mathrm{L}$.

\section{Contaminants in Ground Water}

Contaminants can be introduced into ground water by natural process, human activities, and sometimes are introduced into wells by surface runoff or materials used in constructing the well. Analyses of a limited number of constituents for water-quality samples (table 15) collected from only 101 wells are not adequate for determining all types and areas of contamination in Sedgwick County. However, many of the representative types of ground-water contaminants in the county were detected.

\section{$\underline{\text { Salinity }}$}

Sources of salinity in Sedgwick County include dissolution of naturally occurring soluble minerals in rocks of the county, infiltration of sodium chloride water from the Arkansas River into adjacent alluvium and terrace deposits, and the disposal of brine recovered during the production of oil.

All water samples from wells in the Wellington Formation and Ninnescah Shale that had concentrations of dissolved solids equal to or greater than $1,000 \mathrm{mg} / \mathrm{L}$ were calcium sulfate type water (table 15 and plate 1). These wells are producing water from stratigraphic beds with deposits of gypsum and anhydrite.

Water samples from alluvium and terrace deposits of Wisconsin to Holocene age adjacent to the Arkansas River north of Wichita had sodium chloride type water, with $1,000 \mathrm{mg} / \mathrm{L}$ or more dissolved solids. The source of this sodium chloride type water is the Arkansas River, which receives saline ground water discharged from Permian rocks (primarily contributed by Rattlesnake Creek in Reno County) and has received brine from salt and oil production.

Contamination of ground water by oilfield brines often is indicated by a sodium:chloride (both in milligrams per liter) ratio that is less than 0.60 . Sodium:chloride ratios less than 0.60 were detected in several wells completed in Wisconsin to Holocene alluvium and terrace deposits adjacent to the Arkansas River from Mount Hope to its confluence with the Little Arkansas River (25S-03W-14CCB, 26S-01W05BAB, 26S-01W-15BBB, 26S-01W-18AAA, 26S-01W-22CBD, 26S-02W-04BBD, and 27S01W-12DAA). All of these wells except 26S$01 \mathrm{~W}-05 \mathrm{BAB}$ are on the west side of the river. There are no oilfield activities in this part of the county except just upstream of well 27S-01 W12DAA. It is possible that oilfield activities in 
Table 16. Statistical summary of water-quality data from selected wells in Sedgwick County with longterm records

[Values are given in microsiemens per centimeter at 25 degrees Celsius, $\mu \mathrm{S} / \mathrm{cm}$; milligrams per liter, $\mathrm{mg} / \mathrm{L}$; and micrograms per liter, $\mu \mathrm{g} / \mathrm{L}$. ND means constituent was not detected]

City of Valley Center public-supply well 5

$$
\text { (25S-01W-36ACB, } 52.0 \text { f eet deep) }
$$

Period of record: $1952,1956-58,1960-64,1967,1970,1984-86$

Property or constituent
Number of Median Maximum Minimum sampl es

\begin{tabular}{|c|c|c|c|c|}
\hline Specific conductance, $\mu \mathrm{S} / \mathrm{cm}$ & 13 & 822 & 927 & 700 \\
\hline $\mathrm{pH}$, standard units & 15 & 7.3 & 8.0 & 7.0 \\
\hline Hardness, as $\mathrm{CaCO}_{3}, \mathrm{mg} / \mathrm{L}$ & 14 & 380 & 430 & 310 \\
\hline Hardness, noncarbonate as $\mathrm{CaCO}_{3}, \mathrm{mg} / \mathrm{L}$ & 14 & 74 & 110 & 24 \\
\hline Bicarbonate as $\mathrm{HCO}_{3}, \mathrm{mg} / \mathrm{L}$ & 11 & 380 & 400 & 340 \\
\hline Calcium, dissolved as $\mathrm{Ca}, \mathrm{mg} / \mathrm{L}$ & 14 & 120 & 120 & 91 \\
\hline Magnes ium, dissol ved as $\mathrm{Mg}, \mathrm{mg} / \mathrm{L}$ & 14 & 24 & 31 & 21 \\
\hline Sodium, dissolved as $\mathrm{Na}, \mathrm{mg} / \mathrm{L}$ & 14 & 35 & 43 & 29 \\
\hline Potassium, dissolved as $\mathrm{K}, \mathrm{mg} / \mathrm{L}$ & 7 & 2.2 & 2.9 & 1.7 \\
\hline Sulfate, dissolved as $\mathrm{SO}_{4}, \mathrm{mg} / \mathrm{L}$ & 14 & 120 & 150 & 74 \\
\hline Chloride, dissolved as $\mathrm{Cl}, \mathrm{mg} / \mathrm{L}$ & 14 & 17 & 21 & 9.0 \\
\hline Fluoride, dissolved as $\mathrm{F}, \mathrm{mg} / \mathrm{L}$ & 14 & .4 & .6 & .2 \\
\hline Sil ica, dissolved as $\mathrm{SiO}_{2}$, $\mathrm{mg} / \mathrm{L}$ & 14 & 16 & 18 & 14 \\
\hline Solids, dissol ved, $\mathrm{mg} / \mathrm{L}$ & 14 & 524 & 555 & 420 \\
\hline Nitrate, dissolved as $\mathrm{N}, \mathrm{mg} / \mathrm{L}$ & 10 & 1.3 & 3.0 & .23 \\
\hline $\begin{array}{l}\text { Phosphate, ortho, dissolved } \\
\text { as } \mathrm{PO}_{4}, \mathrm{mg} / \mathrm{L}\end{array}$ & 1 & -- & .06 & - \\
\hline Arsenic, dissolved as As, $\mu \mathrm{g} / \mathrm{L}$ & 2 & -- & 13 & 2 \\
\hline Barlum, dissolved as $\mathrm{Ba}, \mu \mathrm{g} / \mathrm{L}$ & 2 & -- & 160 & 80 \\
\hline Cadmium, dissolved as $\mathrm{Cd}, \mu \mathrm{g} / \mathrm{L}$ & 2 & -- & ND & -- \\
\hline Chromium, dissolved as $\mathrm{Cr}, \mu \mathrm{g} / \mathrm{L}$ & 2 & & 30 & 10 \\
\hline Copper, dissolved as $\mathrm{Cu}, \mu \mathrm{g} / \mathrm{L}$ & 2 & & 20 & ND \\
\hline Iron, dissolved as $\mathrm{Fe}, \mu \mathrm{g} / \mathrm{L}$ & 3 & 250 & 280 & 240 \\
\hline Lead, dissol ved as $\mathrm{Pb}, \mu \mathrm{g} / \mathrm{L}$ & 2 & - & ND & -- \\
\hline Manganese, dissol ved as $\mathrm{Mn}, \mu \mathrm{g} / \mathrm{L}$ & 13 & 130 & 220 & 80 \\
\hline Mercury, dissolved as $\mathrm{Hg}, \mu \mathrm{g} / \mathrm{L}$ & 2 & -- & ND & -- \\
\hline Sel enium, dissolved as Se, $\mu \mathrm{g} / \mathrm{L}$ & 2 & -- & 5 & ND \\
\hline $\mathrm{Z}$ inc, dissolved as $\mathrm{Zn}, \mu \mathrm{g} / \mathrm{L}$ & 2 & -- & 10 & ND \\
\hline
\end{tabular}


Table 16. Statistical summary of water-quality data from selected wells in Sedgwick County with longterm records--Continued

City of Wichita public-supply well M28

$$
\text { (25S-02W-02BAA, } 218 \text { feet deep) }
$$

Period of record: $1948-50,1952,1957-68,1971-72,1985$

Property or constituent

Number of sampl es
Median Maximum

Minimum

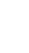

\section{Specif ic conductance, $\mu \mathrm{S} / \mathrm{cm}$}

$\mathrm{pH}$, standard units

Hardness, as $\mathrm{CaCO}_{3}, \mathrm{mg} / \mathrm{L}$

Hardness, noncarbonate as $\mathrm{CaCO}_{3}, \mathrm{mg} / \mathrm{L}$

B icarbonate as $\mathrm{HCO}_{3}, \mathrm{mg} / \mathrm{L}$

Calcium, dissolved as $\mathrm{Ca}, \mathrm{mg} / \mathrm{L}$

Magnesium, $d$ issol ved as $\mathrm{Mg}, \mathrm{mg} / \mathrm{L}$

Sodium, dissolved as $\mathrm{Na}$, $\mathrm{mg} / \mathrm{L}$

Potassium, dissolved as $\mathrm{K}, \mathrm{mg} / \mathrm{L}$

Sulfate, dissolved as $\mathrm{SO}_{4}, \mathrm{mg} / \mathrm{L}$

Chloride, dissolved as $\mathrm{Cl}, \mathrm{mg} / \mathrm{L}$

Fluoride, dissolved as $\mathrm{F}, \mathrm{mg} / \mathrm{L}$

$\mathrm{S} 11$ ica, dissolved as $\mathrm{Sin}_{2}, \mathrm{mg} / \mathrm{I}$.

Sol ids, dissolved, $\mathrm{mg} / \mathrm{L}$

Nitrate, dissolved as $\mathrm{N}, \mathrm{mg} / \mathrm{L}$

Phosphate, ortho, dissolved as $\mathrm{PO}_{4}, \mathrm{mg} / \mathrm{L}$

Iron, dissolved as $\mathrm{Fe}, \mu \mathrm{g} / \mathrm{L}$

Manganese, dissol ved as $\mathrm{Mn}, \mu \mathrm{g} / \mathrm{L}$
4

7

19

19

19

13

13

13

1

16

19

3

6

13

1

1

1

7
675

7.4

240

0

300

75

13

65

--

100

60

.4

16

450

--

$-$

$--$

190
785

8.2

250

0

320

80

16

78

2.9

100

75

.4

37

520

2.3

.06

190

220
550

7.2

180

0

220

64

7.5

44

--

78

27

. 3

1.0

323

--

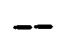

50 
Table 16. Statistical summary of water-quality data from selected wells in Sedgwick County with longterm records--Continued

Park City public-supply well 7

(26S-01E-17AAB, 42.0 feet deep)

Period of record: 1953, 1954, 1960, 1964, 1968, 1984-86

Property or constituent

Number of

Median

Maximum

Minimum samples

Specif ic conductance, $\mu \mathrm{S} / \mathrm{cm}$

$\mathrm{pH}$, standard units

Hardness, as $\mathrm{CaCO}_{3}, \mathrm{mg} / \mathrm{L}$

Hardness, noncarbonate as $\mathrm{CaCO}_{3}, \mathrm{mg} / \mathrm{L} 8$

B icarbonate as $\mathrm{HCO}_{3}, \mathrm{mg} / \mathrm{L}$

Calc ium, dissolved as $\mathrm{Ca}, \mathrm{mg} / \mathrm{L}$

Magnes ium, dissol ved as $\mathrm{Mg}$, $\mathrm{mg} / \mathrm{L}$

Sodium, dissolved as $\mathrm{Na}, \mathrm{mg} / \mathrm{L}$

Potassium, dissolved as $\mathrm{K}$, mg/L

Sulfate, dissolved as $\mathrm{SO}_{4}, \mathrm{mg} / \mathrm{L}$

Chloride, dissolved as $\mathrm{Cl}, \mathrm{mg} / \mathrm{L}$

Fluoride, dissolved as $F, \mathrm{mg} / \mathrm{L}$

$\mathrm{Sil}$ ica, dissol ved as $\mathrm{SiO}_{2}, \mathrm{mg} / \mathrm{L}$

Sol ids, dissolved, $\mathrm{mg} / \mathrm{L}$

Nitrate, dissolved as $\mathrm{N}, \mathrm{mg} / \mathrm{L}$

Phosphate, ortho, dissolved as $\mathrm{PO}_{4}, \mathrm{mg} / \mathrm{L}$

Iron, dissolved as $\mathrm{Fe}, \mu \mathrm{g} / \mathrm{L}$

Manganese, dissol ved as $\mathrm{Mn}, \mu \mathrm{g} / \mathrm{L}$
1,000

7.3

400

99

410

110

32

40

2.3

140

22

.3

18

572

.27

48

150
1,140

7.4

470

210

440

130

41

51

2.4

170

42

.5

19

640

.34

.12

60

450
810

7.1

260

36

260

77

17

29

1.5

83

13

16

369

.14

$\begin{array}{llll}3 & 150 & 450 & 20 \\ 7 & 150\end{array}$


Table 16. Statistical summary of water-quality data from selected wells in Sedgwick County with longterm records--Continued

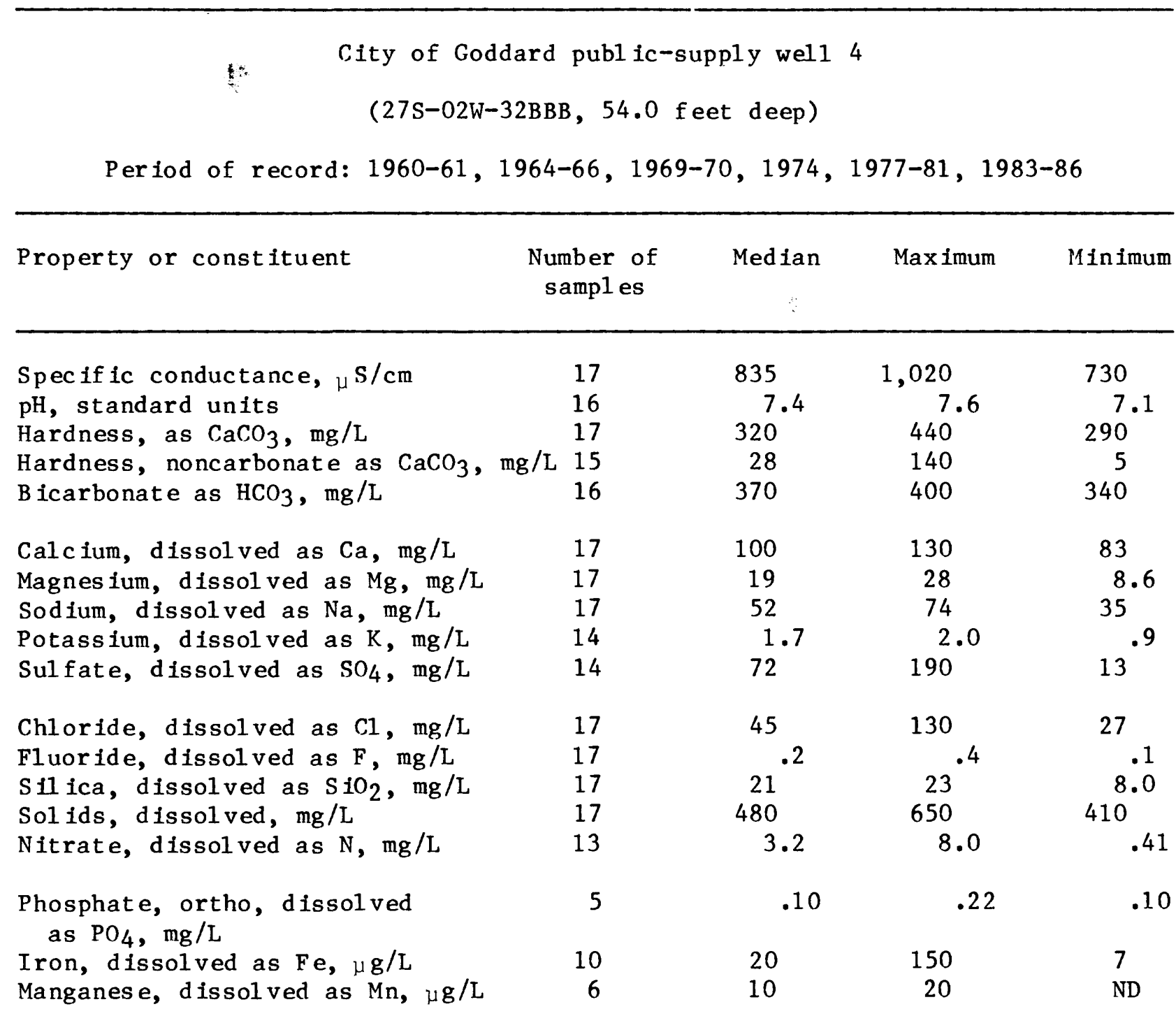


Table 16. Statistical summary of water-quality data from selected wells in Sedgwick County with longterm records.-.Continued

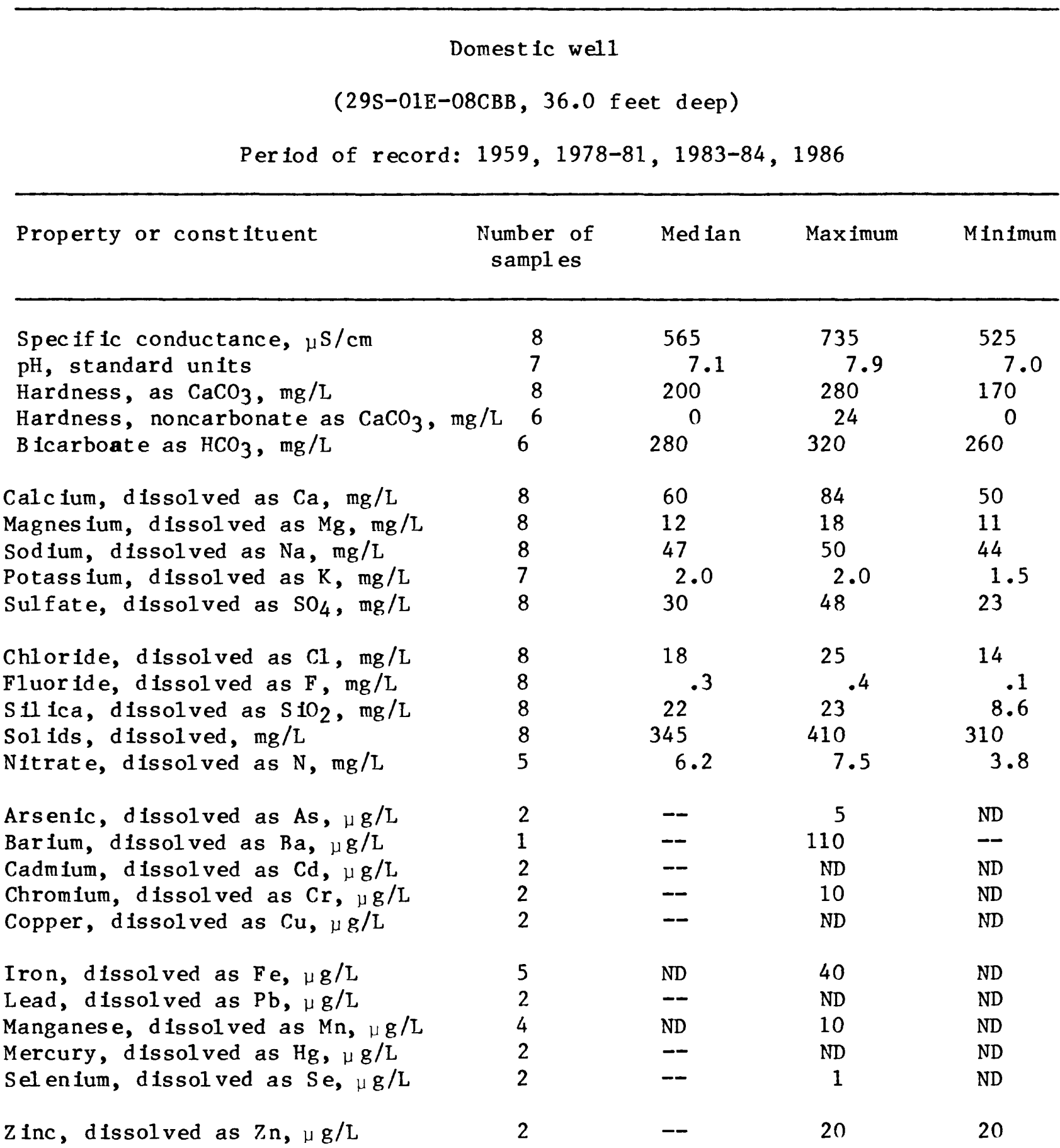


Table 16. Statistical summary of water-quality data from selected wells in Sedgwick County with longterm records--Continued

City of $\mathrm{Cl}$ earwater public-supply well 5

(29S-02W-23DDA, 54.0 feet deep)

Period of record: $1961-62,1964-65,1967,1970,1972,1974,1977-81,1983-85$

\begin{tabular}{|c|c|c|c|c|}
\hline Property or constituent & $\begin{array}{c}\text { Number of } \\
\text { sampl es }\end{array}$ & Median & Maximum & Minimum \\
\hline $\begin{array}{l}\text { Specif ic conductance, } \mu \mathrm{S} / \mathrm{cm} \\
\mathrm{pH} \text {, standard units } \\
\text { Hardness, as } \mathrm{CaCO}_{3}, \mathrm{mg} / \mathrm{L} \\
\text { Hardness, noncarbonate as } \mathrm{CaCO}_{3} \text {, } \\
\text { B icarbonate as } \mathrm{HCO}_{3}, \mathrm{mg} / \mathrm{L}\end{array}$ & $\begin{array}{r}16 \\
16 \\
16 \\
16 \\
14\end{array}$ & $\begin{array}{r}725 \\
7.15 \\
290 \\
85 \\
260\end{array}$ & $\begin{array}{l}820 \\
7.5 \\
330 \\
110 \\
300\end{array}$ & $\begin{array}{l}550 \\
6.8 \\
210 \\
0 \\
230\end{array}$ \\
\hline $\begin{array}{l}\text { Calcium, dissolved as } \mathrm{Ca}, \mathrm{mg} / \mathrm{L} \\
\text { Magnesium, dissol ved as } \mathrm{Mg}, \mathrm{mg} / \mathrm{L} \\
\text { Sodium, dissolved as } \mathrm{Na}, \mathrm{mg} / \mathrm{L} \\
\text { Potassium, dissolved as } \mathrm{K}, \mathrm{mg} / \mathrm{L} \\
\text { Sulfate, dissolved as } \mathrm{SO}_{4}, \mathrm{mg} / \mathrm{L}\end{array}$ & $\begin{array}{l}16 \\
16 \\
16 \\
14 \\
16\end{array}$ & $\begin{array}{l}72 \\
26 \\
39 \\
2.2 \\
58\end{array}$ & $\begin{array}{l}80 \\
33 \\
52 \\
6.0 \\
87\end{array}$ & $\begin{array}{l}64 \\
11 \\
32 \\
2.0 \\
26\end{array}$ \\
\hline $\begin{array}{l}\text { Chloride, dissolved as } \mathrm{C} 1, \mathrm{mg} / \mathrm{L} \\
\text { Fluoride, dissolved as } \mathrm{F}, \mathrm{mg} / \mathrm{L} \\
\mathrm{S} \text { il ica, dissolved as } \mathrm{SiO}, \mathrm{mg} / \mathrm{L} \\
\text { Sol ids, dissolved, } \mathrm{mg} / \mathrm{L} \\
\text { Nitrate, dissolved as } \mathrm{N}, \mathrm{mg} / \mathrm{L}\end{array}$ & $\begin{array}{l}16 \\
16 \\
16 \\
16 \\
13\end{array}$ & $\begin{array}{l}51 \\
24 \\
425 \\
7.2\end{array}$ & $\begin{array}{c}85 \\
2.8 \\
29 \\
500 \\
9.1\end{array}$ & $\begin{array}{r}17 \\
.1 \\
8.0 \\
340 \\
3.3\end{array}$ \\
\hline $\begin{array}{l}\text { Phosphate, ortho, dissolved } \\
\quad \text { as } \mathrm{PO}_{4}, \mathrm{mg} / \mathrm{L} \\
\text { Arsenic, dissolved as } \mathrm{As}, \mu \mathrm{g} / \mathrm{L} \\
\text { Rarium, } \mathrm{d} \text { issol ved as } \mathrm{Ba}, \mu \mathrm{g} / \mathrm{L} \\
\text { Cadmium, dissolved as } \mathrm{Cd}, \mu \mathrm{g} / \mathrm{L} \\
\text { Chromium, dissol ved as } \mathrm{Cr}, \mu \mathrm{g} / \mathrm{L}\end{array}$ & $\begin{array}{l}4 \\
2 \\
4 \\
4\end{array}$ & $\begin{array}{r}4 \\
-- \\
\text { ND } \\
\text { ND }\end{array}$ & $\begin{array}{r}6 \\
170 \\
\text { ND } \\
10\end{array}$ & $\begin{array}{l}-- \\
\text { ND } \\
60 \\
\text { ND } \\
\text { ND }\end{array}$ \\
\hline $\begin{array}{l}\text { Copper, dissolved as } \mathrm{Cu}, \mu \mathrm{g} / \mathrm{L} \\
\text { Iron, dissolved as } \mathrm{Fe}, \mu \mathrm{g} / \mathrm{L} \\
\text { Lead, dissolved as } \mathrm{Pb}, \mu \mathrm{g} / \mathrm{L} \\
\text { Manganese, dissolved as } \mathrm{Mn}, \mu \mathrm{g} / \mathrm{L} \\
\text { Mercury, dissolved as } \mathrm{Hg}, \mu \mathrm{g} / \mathrm{L}\end{array}$ & $\begin{array}{r}4 \\
11 \\
4 \\
4 \\
4\end{array}$ & $\begin{array}{l}20 \\
20 \\
\text { ND } \\
\text { ND } \\
\text { ND }\end{array}$ & $\begin{array}{l}40 \\
70 \\
\text { ND } \\
4 \\
1.1\end{array}$ & $\begin{array}{l}10 \\
10 \\
\text { ND } \\
\text { ND } \\
\text { ND }\end{array}$ \\
\hline $\begin{array}{l}\text { Sel enium, dissol ved as } \mathrm{Se}, \mu \mathrm{g} / \mathrm{L} \\
\mathrm{Z} \text { inc, dissolved as } \mathrm{Zn}, \mu \mathrm{g} / \mathrm{L}\end{array}$ & $\begin{array}{l}4 \\
4\end{array}$ & $\begin{array}{r}2 \\
40\end{array}$ & $\begin{array}{r}5 \\
80\end{array}$ & $\begin{array}{l}\text { ND } \\
\text { ND }\end{array}$ \\
\hline
\end{tabular}


generally exceed the water-quality criterion (U.S. Environmental Protection Agency, 1986b).

City of Wichita public-supply well M28 (25S-02W-02BAA) is 218 feet deep and yields water from unconsolidated deposits in the Equus beds aquifer ranging in age from Pliocene to Holocene. Water from this well is a calcium sodium bicarbonate type, with a median dissolved-solids concentration of $450 \mathrm{mg} / \mathrm{L}$. The water has a median concentration of hardness as calcium carbonate of $240 \mathrm{mg} / \mathrm{L}$. Concentrations of manganese (median concentration, $190 \mu \mathrm{g} / \mathrm{L}$ ) generally exceed the water-quality criterion.

Park City public-supply well 7 (26S-01E$17 \mathrm{AAB}$ ) is 42.0 feet deep and yields water from alluvium and terrace deposits of the Little Arkansas River. The water from this well is a calcium bicarbonate type, with a median dissolved-solids concentration of $572 \mathrm{mg} / \mathrm{L}$. The water has a median concentration of hardness as calcium carbonate of $400 \mathrm{mg} / \mathrm{L}$. Concentrations of manganese (median concentration, $150 \mu \mathrm{g} / \mathrm{L}$ ) generally exceed the water-quality criterion.

Goddard public-supply well 4 (27S-02W32BBB) is 54.0 feet deep and yields water from unconsolidated deposits of pre-Illinoian age. The water is a calcium bicarbonate type, with a median dissolved-solids concentration of 480 $\mathrm{mg} / \mathrm{L}$. The water has a median concentration of hardness as calcium carbonate of $320 \mathrm{mg} / \mathrm{L}$.

Long-term water-quality data also are available for a domestic well (29S-01E-08CBB) that is 36.0 feet deep and yields water from alluvium and terrace deposits of Wisconsin to Holocene age in the Arkansas River valley. Water from this well is a calcium bicarbonate type, with a median dissolved-solids concentration of $345 \mathrm{mg} / \mathrm{L}$. The water has a median concentration of hardness as calcium carbonate of $200 \mathrm{mg} / \mathrm{L}$.

Clearwater public-supply well 5 (29S02W-23DDA) is 54.0 feet deep and yields water from terrace deposits of Illinoian age. The water is a calcium bicarbonate type, with a median dissolved-solids concentration of $425 \mathrm{mg} / \mathrm{L}$. The water has a median concentration of hardness as calcium carbonate of $290 \mathrm{mg} / \mathrm{L}$. Mercury (maximum concentration, $1.1 \mu \mathrm{g} / \mathrm{L}$ ) has exceeded the water-quality criterion (U.S. Environmental Protection Agency, 1986c).

\section{Wichita Well Field}

The Wichita well field in southwest Harvey County (in parts of township 23 south, range 2 west and township 24 south, ranges 2 and 3 west) and northwest Sedgwick County (in parts of township 25 south, ranges 1 and 2 west) yields water for public supplies from the Equus beds aquifer. The original well field, located in Harvey County, was established in 1940 when 25 wells were used to withdraw about 3,900 acrefeet of water. The current (1986) public-supply and observation-well network of the Wichita well field is shown in figure 20. During 1985, nearly 35,200 acre-feet of water were withdrawn from 55 wells in the well field. During 1940 through 1985 , a total of approximately $1,268,400$ acre-feet of water have been withdrawn from the well field for public supplies (data from city of Wichita). The city of Wichita currently has appropriated ground-water rights to withdraw about 40,000 acre-feet annually (Lorenz and others, 1985).

\section{Water Yield}

A previous investigation determined that the Wichita well field had a potential perennial yield of about 40,000 acre-feet (Williams and Lohman, 1947). The perennial yield was defined as being equivalent to the sum of all natural recharge (precipitation and inflow), assuming that the water table was lowered to a degree that all natural recharge could be intercepted. This estimate of potential perennial yield was used to develop the ground-water appropriation for the well field. Williams and Lohman (1947) also determined that in order for all natural recharge to be intercepted that about 200,000 acre-feet of water would have to be removed from storage. By the end of 1950, more than 200,000 acre-feet of water had been withdrawn from the well field although annual withdrawals had increased to only about 26,000 acre-feet. If the estimate of perennial yield by Williams and Lohman (1947) was accurate, the water-level declines in the well field should have stabilized by about 1950 . However, this has not occurred as can be seen by comparing water-level declines in the well field during selected time intervals (fig. 20). 


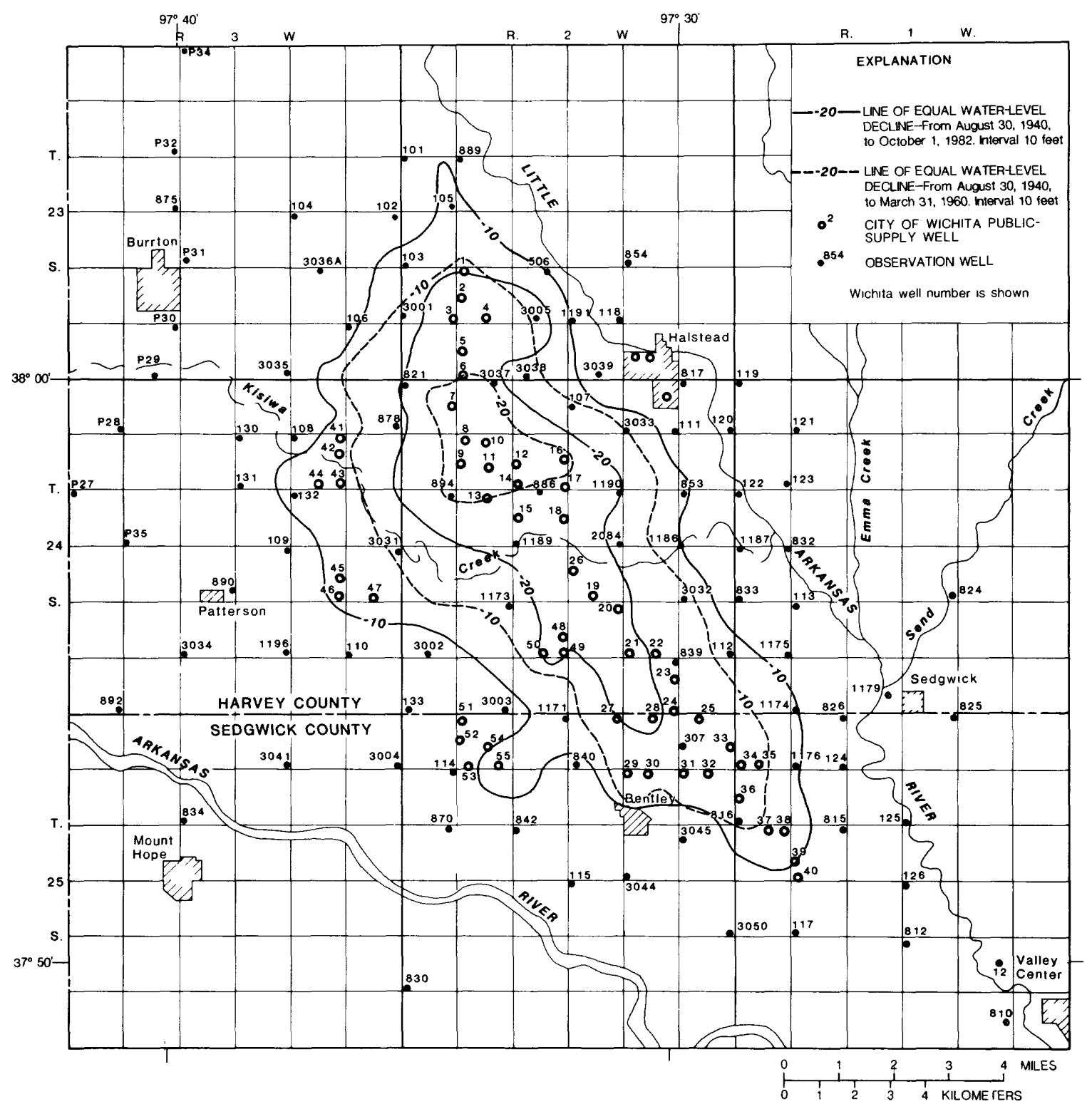

Figure 20. Wichita well field in southwest Harvey and northwest Sedgwick Counties, public-supply and observation-well network, and water-level declines from August 30, 1940, to March 31, 1960, and from August 30, 1940, to October 1, 1982.

The water-level declines shown in figure 20 represent declines that occurred from the base period of 1940 to 1960 and from 1940 to 1982. The years 1960 and 1982 were selected for comparison because the cumulative departure from average precipitation, shown previously in figure 18 , indicates that precipitation was about average during 1940,1960 , and 1980 , and that the cumulative departures from average precipitation were nearly equivalent. Because the climatic conditions were similar during these years, any change in water levels in the well field would be caused by withdrawals. The area where water levels had declined 20 feet or more had increased by approximately four times between 1960 and 1982, and the area where water-level declines were 10 feet or more also had increased substantially even though less than 40,000 acre-feet of ground water were withdrawn in 1982 . However, increasing groundwater withdrawals for irrigation in the vicinity of the well field since 1960 probably have contributed to the decline of water levels since then. 
Williams and Lohman (1947) estimated that natural recharge to the well field from precipitation was about 6 inches. A more recent ground-water modeling investigation used annual recharge from precipitation ranging from 2.5 to 4.0 inches (Spinazola and others, 1985). If a value of 3.25 inches (averaged used by Spinazola) were used in the computation by Williams and Lohman, the estimated perennial yield would decrease from 40,000 acre-feet to less than 30,000 acre-feet. This difference in recharge from precipitation may be the reason that water levels in the well field have continued to decline, although withdrawals for irrigation are also a major factor. Assuming recharge by precipitation of 3.25 inches per year, the area affected by the well field would have to exceed 155 square miles before the water levels would stabilize. By 1982, water-level declines of 2 feet or more had occurred in a 135-square-mile area in and adjacent to the well field. In recent years since 1982, the areas of water-level decline in the well field have been relatively stable.

Although water-level declines greater than 25 feet occasionally have been observed in localized parts of the well field, the saturated thickness of unconsolidated deposits ranged from about 140 to 250 feet in 1980 (Spinazola and others, 1985). Spinazola used a threedimensional finite-difference ground-water flow model to project the effects of ground-water withdrawals in the Equus beds aquifer, including the Wichita well field. He estimated that continued withdrawals from the well field at the rate observed during the 1970's (about 30,000 acre-feet per year) would cause additional waterlevel declines of about 15 feet during 1980-2020, assuming that withdrawals for irrigation also remained constant. If withdrawals were doubled (including irrigation), water levels in the well field would decline an additional 40 feet during 1980-2020, and the saturated thickness of unconsolidated deposits would range from about 95 to 210 feet by 2020 .

\section{Water Quality}

Water-quality data collected since 1980 from the vicinity of the Wichita well field are presented in table 17. These data were compiled from reports of the Kansas Geological Survey (Hathaway and others, 1981), the Burrton Task Force (1984), and from data files of the U.S.
Geological Survey (including data collected during this investigation).

Water from wells in the Wichita well field generally is a calcium bicarbonate type, with less than $500 \mathrm{mg} / \mathrm{L}$ dissolved solids. Water with concentrations of dissolved solids exceeding $\mathbf{5 0 0}$ $\mathrm{mg} / \mathrm{L}$ in the vicinity of the well field usually has relatively large concentrations of sodium, sulfate, or chloride. Concentrations of nitrate as nitrogen occasionally exceed the water-quality criterion of $10 \mathrm{mg} / \mathrm{L}$ (U.S. Environmental Protection Agency, 1986c), and concentrations of iron and manganese in water from many wells in the area exceed public-supply criteria of 300 and 50 g/L (U.S. Environmental Protection Agency, $1986 \mathrm{~b})$, respectively.

Sodium chloride type ground water, with large concentrations of dissolved solids (exceeding $1,000 \mathrm{mg} / \mathrm{L}$ ), occurs in areas adjacent to the western edge of the well field. The sodium chloride water is derived from dissolution of salt beds in Permian rocks and from past disposal of oilfield brine in the Burrton oilfield. The Wellington Formation of Permian age underlies the unconsolidated deposits in the well field. The Hutchinson Salt Member of the Wellington Formation has been dissolved by ground water in areas south and west of the well field, resulting in the formation of a discontinuous zone of solution cavities and collapsed beds that is referred to as the Wellington aquifer (Gogel, 1981). Digital flow modeling by Gogel (1981) predicted that the potentiometric surface of water in the Wellington aquifer is higher than the potentiometric surface in the overlying unconsolidated deposits in an area adjacent to Kisiwa Creek south of Burrton. Also, because less than $\mathbf{1 0 0}$ feet of shale is present between the Wellington aquifer and the unconsolidated deposits, there is potential for the upward movement of halite-solution brine into the freshwater aquifer in this area. Relatively large concentrations of chloride ions and sodium:chloride ratios greater than 0.60 in several wells in the vicinity of Patterson (fig. 1) may be due to upward movement of brine from the Wellington aquifer. However, a detailed investigation in this area is needed before any conclusions can be drawn.

The Arkansas River receives sodium chloride water from ground water discharged by 
Table 17. Water-quality data for wells in vicinity of Wichita well field, 1980-85.

\begin{tabular}{|c|c|c|c|c|c|c|c|c|c|c|c|c|c|}
\hline \multirow{3}{*}{$\begin{array}{l}\text { Well } \\
\text { number } \\
\text { (township- } \\
\text { range-section, } \\
\text { f1g. 22) }\end{array}$} & \multirow{3}{*}{$\begin{array}{l}\text { Date } \\
\text { sampled } \\
\text { (month- } \\
\text { day-year) }\end{array}$} & \multirow{3}{*}{$\begin{array}{l}\text { Depth } \\
\text { of well, } \\
\text { in feet }\end{array}$} & \multicolumn{8}{|c|}{$\begin{array}{l}\text { Concentration of constituent, in } \\
\text { milligrams per liter; ND, not detected }\end{array}$} & \multirow{3}{*}{$\begin{array}{l}\text { Sodium: } \\
\text { chloride } \\
\text { ratiol } \\
(\mathrm{Na} / \mathrm{Cl})\end{array}$} & \multirow{2}{*}{\multicolumn{2}{|c|}{$\begin{array}{l}\text { Concentration } \\
\text { of constituent, } \\
\text { in micrograms } \\
\text { per liter }\end{array}$}} \\
\hline & & & $\begin{array}{l}\text { Hard- } \\
\text { ness, } \\
\text { as }\end{array}$ & $\begin{array}{l}\text { Cal- } \\
\text { cium, } \\
\text { as Ca }\end{array}$ & $\begin{array}{l}\text { Sod- } \\
\text { ium, } \\
\text { as }\end{array}$ & $\begin{array}{l}\text { Bicar- } \\
\text { bon- } \\
\text { ate, }\end{array}$ & $\begin{array}{l}\text { Sul- } \\
\text { fate, } \\
\text { as }\end{array}$ & $\begin{array}{l}\text { Chlo- } \\
\text { ride, } \\
\text { as }\end{array}$ & $\begin{array}{l}\text { Dis- } \\
\text { solved } \\
\text { solids }\end{array}$ & $\begin{array}{l}\text { Nitrate, } \\
\text { as } \mathrm{N}\end{array}$ & & & \\
\hline & & & & & & $\begin{array}{l}\text { as } \\
\mathrm{HCO}_{3}\end{array}$ & $\mathrm{SO}_{4}$ & & & & & $\begin{array}{l}\text { Iron, } \\
\text { as } \mathrm{Fe}\end{array}$ & $\begin{array}{l}\text { Manganese, } \\
\text { as Mn }\end{array}$ \\
\hline $23 S-02 W-29 B^{2} C^{2}$ & $07-29-80$ & -- & 110 & 35 & 31 & 180 & 18 & 6.0 & 230 & 0.02 & -- & 10 & 260 \\
\hline $23 \mathrm{~S}-02 \mathrm{~W}-29 \mathrm{CDD}^{3}$ & $08-01-85$ & 237 & 120 & 39 & 26 & 190 & 21 & 7.8 & 220 & .09 & -- & 60 & 300 \\
\hline $23 \mathrm{~S}-03 \mathrm{~W}-04 \mathrm{BBB}^{4}$ & $10-15-82$ & 78 & -- & -- & -- & - & $-\infty$ & 3.0 & -- & -- & -- & -- & -- \\
\hline $23 S-03 W-07 D^{2} A^{4}$ & $12-14-82$ & 20 & 410 & 130 & 39 & 32 & 6.5 & 310 & -- & 2.2 & 0.12 & -- & -- \\
\hline $23 \mathrm{~S}-03 \mathrm{~W}-08 \mathrm{BBB}^{4}$ & $10-15-82$ & 146 & -- & - & -- & - & -- & 4.0 & -- & -- & -- & -- & -- \\
\hline $23 S-03 w-08 D^{2} D^{4}$ & $10-15-82$ & 89 & -- & -- & -- & -- & -- & 6.0 & -- & -- & -- & - & -- \\
\hline $23 \mathrm{~S}-03 \mathrm{~W}-10 \mathrm{BBB}^{4}$ & $12-14-82$ & 50 & -- & - & -- & -- & -- & 8.0 & -- & -- & -- & -- & -- \\
\hline $23 \mathrm{~S}-03 \mathrm{~W}-10 \mathrm{CCA}^{4}$ & $10-15-82$ & 137 & -- & -- & - & - & - & 5.0 & -- & -- & -- & -- & -- \\
\hline $23 \mathrm{~S}-03 \mathrm{~W}-16 \mathrm{DDB}^{2}$ & $07-29-80$ & -- & 130 & 40 & 44 & 220 & 19 & 10 & 260 & .11 & -- & 770 & 350 \\
\hline $23 \mathrm{~S}-03 \mathrm{~W}-17 \mathrm{AAB}^{4}$ & $12-14-82$ & 25 & 12 & 35 & 13 & 43 & 28 & 18 & -- & 12 & -- & -- & -- \\
\hline $23 \mathrm{~S}-03 \mathrm{~W}-19 \mathrm{BBB}^{4}$ & $10-23-82$ & 175 & -- & -- & -- & - & - & 10 & -- & - & -- & -- & -- \\
\hline $23 s-03 w-19 D C c^{4}$ & $01-20-83$ & 124 & 470 & 140 & 130 & 170 & 36 & 400 & -- & .5 & .32 & -- & -- \\
\hline $23 S-03 W-19 D D D^{4}$ & $12-14-82$ & 110 & 1,670 & 520 & 490 & 73 & 54 & 1,830 & -- & $\mathrm{ND}$ & .27 & -- & -- \\
\hline $23 S-03 w-20 D B C 4$ & $12-14-82$ & 33 & - & - & -- & - & -- & 150 & -- & -- & -- & -- & -- \\
\hline $23 S-03 W-21 A D C^{2}$ & $07-29-80$ & -- & 440 & 140 & 97 & 89 & 21 & 400 & 780 & .77 & .24 & 2,100 & 190 \\
\hline $23 s-03 w-21 \operatorname{ccc}^{4}$ & $12-14-82$ & 65 & 820 & 240 & 480 & 99 & 32 & 1,220 & -- & ND & .39 & -- & -- \\
\hline $23 \mathrm{~S}-03 \mathrm{~W}-22 \mathrm{BBB}^{4}$ & $12-14-82$ & 53 & 530 & 170 & 240 & 60 & 25 & 660 & -- & 5.00 & .36 & -- & -- \\
\hline $23 \mathrm{~S}-03 \mathrm{~W}-22 \mathrm{DBD}^{2}$ & $07-29-80$ & -- & 100 & 32 & 29 & 160 & 15 & 12 & 200 & -- & -- & -- & 250 \\
\hline $23 S-03 W-23 B_{B B}^{4}$ & $10-15-82$ & 140 & -- & -- & -- & -- & -- & 5 & -- & - & -- & -- & -- \\
\hline $23 S-03 W-26 B_{B B}^{4}$ & $10-14-82$ & 66 & -- & -- & -- & -- & -- & 190 & -- & - & -- & -- & -- \\
\hline $23 s-03 w-27 B C c^{4}$ & $12-14-82$ & 100 & 650 & 200 & 380 & 120 & 52 & 920 & -- & .1 & .41 & -- & -- \\
\hline $23 S-03 w-28 B^{4}$ & $12-14-82$ & 29 & 270 & 80 & 77 & 180 & 163 & 160 & -- & 2.6 & .48 & -- & -- \\
\hline $23 S-03 W-29 D_{B D}^{3}$ & $08-01-85$ & -- & 250 & 74 & 67 & 190 & 76 & 100 & 460 & 4.42 & -- & 90 & 10 \\
\hline $23 S-03 W-32 A A A^{4}$ & $12-14-82$ & 128 & 970 & 300 & 430 & 210 & 32 & 1,180 & -- & .2 & .36 & -- & -- \\
\hline $23 S-03 W-34 D_{B B}^{4}$ & $12-14-82$ & 130 & 380 & 120 & 67 & 240 & 39 & 220 & -- & ND & .30 & -- & -- \\
\hline $23 S-03 W-34 D^{4} D^{4}$ & $12-14-82$ & 125 & -- & -- & - & -- & - & 29 & -- & -- & -- & -- & -- \\
\hline $23 S-03 W-36 A B C^{2}$ & $07-29-80$ & -- & 120 & 36 & 26 & 130 & 31 & 16 & 240 & 5.9 & -- & 84 & 27 \\
\hline $24 \mathrm{~S}-01 \mathrm{~W}-18 \mathrm{CCA}^{2}$ & $07-29-80$ & -- & 140 & 64 & 58 & 310 & 44 & 21 & 370 & .04 & -- & 1,900 & 480 \\
\hline $24 S-01 W-29$ B BC $^{2}$ & $07-29-80$ & -- & 270 & 84 & 98 & 370 & 140 & 28 & 570 & .02 & -- & 770 & 630 \\
\hline $24 \mathrm{~S}-02 \mathrm{~W}-02 \mathrm{AAC}^{3}$ & $09-23-80$ & 20 & 190 & 62 & 45 & 220 & 76 & 21 & 360 & 2.7 & - & -- & -- \\
\hline $24 S-02 W-05 D D D A^{2}$ & $07-29-80$ & -- & 110 & 36 & 44 & 200 & 23 & 11 & 240 & .05 & -- & 510 & 250 \\
\hline $24 \mathrm{~S}-02 \mathrm{~W}-06 \mathrm{DBD} 2$ & $07-29-80$ & -- & 160 & 51 & 34 & 200 & 61 & 14 & 310 & .02 & -- & 2,300 & 190 \\
\hline $24 \mathrm{~S}-02 \mathrm{~W}-12 \mathrm{CCC}^{2}$ & $07-29-80$ & -- & 200 & 65 & 60 & 280 & 90 & 10 & 390 & .04 & -- & 2,200 & 360 \\
\hline $24 \mathrm{~S}-02 \mathrm{~W}-17 \mathrm{CAA}^{2}$ & $07-29-80$ & -- & 320 & 100 & 91 & 280 & 170 & 73 & 600 & .04 & -- & 1,800 & 330 \\
\hline $24 \mathrm{~S}-02 \mathrm{~W}-23 \mathrm{~B} \mathrm{BC}^{2}$ & $07-29-80$ & -- & 350 & 110 & 49 & 200 & 260 & 12 & 600 & .75 & -- & 4,100 & 530 \\
\hline $24 \mathrm{~S}-02 \mathrm{~W}-23 \mathrm{BD} C^{2}$ & $07-29-80$ & -- & 200 & 62 & 35 & 170 & 93 & 19 & 340 & 2.1 & -- & 3,400 & 430 \\
\hline $24 \mathrm{~S}-02 \mathrm{~W}-23 \mathrm{BBB}^{3}$ & $09-23-80$ & 80 & 340 & 110 & 48 & 210 & 240 & 15 & 560 & 9 & -- & -- & -- \\
\hline $24 S-02 W-27 C^{2}$ & $07-29-80$ & -- & 280 & 86 & 69 & 280 & 160 & 22 & 480 & .04 & -- & 3,500 & 560 \\
\hline $24 S-02 W-29 D D B^{2}$ & $07-29-80$ & -- & 270 & 82 & 76 & 310 & 110 & 54 & 490 & .04 & -- & 660 & 520 \\
\hline $24 S-03 W-01 B B B A^{4}$ & $12-14-82$ & 90 & -- & -- & -- & - & -- & 71 & -- & - & -- & -- & -- \\
\hline $24 S-03 W-01 D^{4} D^{4}$ & $12-14-82$ & 44 & -- & -- & -- & -- & -- & 35 & -- & -- & -- & -- & -- \\
\hline $24 S-03 W-03 D D C^{4}$ & $12-14-82$ & 31 & -- & -- & -- & -- & -- & 63 & -- & - & -- & -- & -- \\
\hline $24 \mathrm{~S}-03 \mathrm{~W}-04 \mathrm{BAA}^{4}$ & $12-14-82$ & 63 & -- & -- & -- & -- & -- & 52 & -- & -- & - & -- & -- \\
\hline $24 \mathrm{~S}-03 \mathrm{~W}-05 \mathrm{ACC} \mathrm{C}^{2}$ & $07-29-80$ & -- & 260 & 76 & 74 & 230 & 60 & 110 & 490 & .25 & .67 & 1,100 & 42 \\
\hline $24 S-03 w-07 B^{-1} C^{4}$ & $12-13-82$ & 35 & 1,050 & 340 & 120 & 370 & 230 & 240 & -- & 105 & .50 & -- & -- \\
\hline $24 S-03 w-07 C D D D^{4}$ & $12-14-82$ & 37 & -- & -- & -- & - & -- & 170 & -- & -- & $-\infty$ & -- & -- \\
\hline $24 S-03 W-08 D_{B B}^{2}$ & $07-29-80$ & -- & 270 & 80 & 89 & 290 & 90 & 90 & 530 & .61 & -- & 910 & 150 \\
\hline $24 \mathrm{~S}-03 \mathrm{~W}-11 \mathrm{DDD}^{4}$ & $12-14-82$ & 54 & -- & -- & - & -- & -- & 92 & -- & -- & - & -- & -- \\
\hline $24 S-03 W-13 D A A^{4}$ & $12-13-82$ & 130 & 5 & 2.0 & 230 & 290 & 150 & 93 & -- & .6 & -- & -- & -- \\
\hline $24 S-03 W-15 D^{2} A^{4}$ & $12-14-82$ & 30 & 30 & 9.5 & 130 & 20 & 79 & 170 & -- & ND & .76 & -- & -- \\
\hline $24 S-03 W-15 D C D^{2}$ & $07-29-80$ & -- & 390 & 120 & 100 & 360 & 150 & 110 & 690 & .45 & .91 & 1,300 & 290 \\
\hline $24 S-03 W-17 D D D^{4}$ & $12-13-82$ & 80 & 190 & 56 & 95 & 140 & 39 & 170 & -- & .9 & .56 & -- & - \\
\hline $24 \mathrm{~S}-03 \mathrm{~W}-20 \mathrm{BBD}^{2}$ & $07-29-80$ & -- & 340 & 110 & 100 & 320 & 110 & 110 & 550 & 2.5 & .91 & 87 & 81 \\
\hline $24 S-03 W-22 C^{2} B^{2}$ & $07-29-80$ & -- & 360 & 110 & 130 & 330 & 160 & 140 & 710 & .52 & .93 & 750 & 200 \\
\hline $24 S-03 W-24 C^{2}$ & $07-29-80$ & -- & 290 & 89 & 62 & 310 & 100 & 46 & 480 & 1.1 & -- & 280 & 43 \\
\hline $24 S-03 W-26 A^{2} A^{3}$ & $08-01-85$ & 75 & 170 & 150 & 120 & 400 & 250 & 110 & 890 & ND & 1.09 & 2,700 & 210 \\
\hline $24 \mathrm{~S}-03 \mathrm{~W}-26 \mathrm{~B}^{2}$ & $07-29-80$ & -- & 350 & 109 & 3.7 & 370 & 84 & 86 & 590 & 5.4 & -- & 380 & 76 \\
\hline $24 S-03 W-26 C D D^{4}$ & $12-14-82$ & -- & -- & -- & - & $-\infty$ & -- & 92 & -- & - & - & -- & -- \\
\hline $24 S-03 W-29 B B A^{4}$ & $12-14-82$ & 47 & -- & -- & -- & -- & -- & 91 & -- & -- & -- & -- & -- \\
\hline $24 S-03 W-30 C B B^{4}$ & $12-14-82$ & 35 & 360 & 120 & 83 & 280 & 77 & 130 & -- & 9.0 & .64 & -- & -- \\
\hline
\end{tabular}


Table 17. Water-quality data for wells in vicinity of Wichita well field, 1980-85--Continued

\begin{tabular}{|c|c|c|c|c|c|c|c|c|c|c|c|c|c|}
\hline \multirow{3}{*}{$\begin{array}{l}\text { Well } \\
\text { number } \\
\text { (township- } \\
\text { range-section, } \\
\text { fig. 22) }\end{array}$} & \multirow{3}{*}{$\begin{array}{l}\text { Date } \\
\text { sampled } \\
\text { (month- } \\
\text { day-year) }\end{array}$} & \multirow{3}{*}{$\begin{array}{l}\text { Depth } \\
\text { of well, } \\
\text { in feet }\end{array}$} & \multicolumn{8}{|c|}{$\begin{array}{l}\text { Concentration of constituent, in } \\
\text { milligrams per liter; ND, not detected }\end{array}$} & \multirow{3}{*}{$\begin{array}{l}\text { Sodium: } \\
\text { chloride } \\
\text { ratiol } \\
(\mathrm{Na} / \mathrm{Cl})\end{array}$} & \multirow{2}{*}{\multicolumn{2}{|c|}{$\begin{array}{l}\text { Concentration } \\
\text { of constituent, } \\
\text { in micrograms } \\
\text { per liter }\end{array}$}} \\
\hline & & & $\begin{array}{l}\text { Hard- } \\
\text { ness, } \\
\text { as }\end{array}$ & $\begin{array}{l}\text { Cal- } \\
\text { cium, } \\
\text { as Ca }\end{array}$ & $\begin{array}{l}\text { Sod- } \\
\text { lum, } \\
\text { as }\end{array}$ & $\begin{array}{l}\text { Bicar- } \\
\text { bon- } \\
\text { ate, }\end{array}$ & $\begin{array}{l}\text { Sul- } \\
\text { fate, } \\
\text { as }\end{array}$ & $\begin{array}{l}\text { Chlo- } \\
\text { ride, } \\
\text { as }\end{array}$ & $\begin{array}{l}\text { Dis- } \\
\text { solved } \\
\text { solids }\end{array}$ & $\begin{array}{l}\text { Nitrate, } \\
\text { as } \mathrm{N}\end{array}$ & & & \\
\hline & & & $\mathrm{CaCO}_{3}$ & & & $\begin{array}{l}\text { as } \\
\mathrm{HCO}_{3} \\
\end{array}$ & $\mathrm{SO}_{4}$ & & & & & $\begin{array}{l}\text { Iron, } \\
\text { as } \mathrm{Fe}\end{array}$ & $\begin{array}{l}\text { Manganese, } \\
\text { as Mn }\end{array}$ \\
\hline $24 S-03 W-32 B^{2}$ & $07-29-80$ & -- & 230 & 70 & 120 & 280 & 65 & 150 & 560 & 1.2 & 0.80 & $<8$ & $<3$ \\
\hline $24 S-03 w-33 B^{4} D^{4}$ & $12-14-82$ & 50 & - & - & - & - & - & 120 & - & -- & -- & - & - \\
\hline $25 S-01 W-06 D_{B B}^{2}$ & $07-29-80$ & -- & 230 & 71 & 55 & 270 & 88 & 27 & 400 & .93 & -- & 480 & 120 \\
\hline $25 \mathrm{~S}-01 \mathrm{~W}-07 \mathrm{BAA}^{3}$ & $08-14-85$ & 130 & 250 & 81 & 38 & 260 & 66 & 18 & 360 & 6.3 & -- & 7 & 44 \\
\hline $25 S-01 W-21 B^{2}$ & $07-29-80$ & -- & 310 & 97 & 58 & 370 & 88 & 32 & 480 & .04 & -- & 250 & 190 \\
\hline $25 S-01 W-27 A B C^{2}$ & $07-29-80$ & -- & 340 & 100 & 50 & 350 & 110 & 30 & 490 & .86 & -- & 160 & 280 \\
\hline $25 S-01 w-27 \operatorname{ccc}^{3}$ & $08-13-85$ & 40 & 250 & 79 & 37 & 260 & 82 & 16 & 370 & .95 & -- & $<3$ & 5 \\
\hline $25 \mathrm{~S}-01 \mathrm{~W}-30 \mathrm{ABB}^{3}$ & $08-13-85$ & 32 & 280 & 89 & 51 & 230 & 60 & 47 & 400 & 21.0 & -- & $<3$ & $<1$ \\
\hline $25 \mathrm{~S}-01 \mathrm{~W}-31 \mathrm{~B}^{2}$ & $07-29-80$ & - & 270 & 81 & 100 & 300 & 69 & 130 & 580 & .73 & .77 & $<8$ & $<3$ \\
\hline $25 \mathrm{~S}-01 \mathrm{~W}-32 \mathrm{BCB} 2$ & $07-29-80$ & - & 300 & 90 & 130 & 180 & 120 & 220 & 750 & 8.4 & .59 & $<8$ & $<3$ \\
\hline $25 S-01 w-32 \mathrm{CDA}^{2}$ & $07-29-80$ & - & 360 & 110 & 110 & 270 & 79 & 220 & 710 & 1.2 & .50 & 8 & $<3$ \\
\hline $25 S-01 W-35 A^{2} C^{3}$ & $08-13-85$ & 37 & 460 & 150 & 38 & 350 & 170 & 25 & 600 & $<.10$ & -- & 130 & 75 \\
\hline $25 S-02 W-02 B^{3} A^{3}$ & $08-14-85$ & 218 & 240 & 76 & 78 & 300 & 78 & 60 & 480 & .23 & -- & 190 & 210 \\
\hline $25 S-02 w-03 D D^{2}$ & $07-29-80$ & -- & 280 & 90 & 43 & 290 & 65 & 26 & 430 & 7.5 & -- & $<8$ & 20 \\
\hline $25 s-02 w-07 D c^{2}$ & $07-29-80$ & -- & 220 & 67 & 86 & 240 & 62 & 89 & 490 & 7.3 & -- & $<8$ & $<3$ \\
\hline $25 S-02 W-10 A A B^{2}$ & $07-29-80$ & - & 260 & 83 & 47 & 280 & 45 & 30 & 430 & 9.1 & -- & $<8$ & 12 \\
\hline $25 S-02 W-12 D_{B D}^{2}$ & $07-29-80$ & - & 200 & 63 & 43 & 220 & 53 & 30 & 360 & 3.4 & - & $<8$ & 150 \\
\hline $25 \mathrm{~S}-02 \mathrm{~W}-15 \mathrm{ABB}^{2}$ & $07-29-80$ & - & 220 & 68 & 68 & 300 & 56 & 39 & 410 & .02 & - & 300 & 110 \\
\hline $25 S-02 w-15 c^{2}$ & $07-29-80$ & - & 210 & 63 & 47 & 200 & 40 & 44 & 380 & 13 & -- & $<8$ & $<3$ \\
\hline $25 s-02 w-15 D D D^{3}$ & $08-12-85$ & -- & 200 & 59 & 40 & 200 & 46 & 45 & 320 & 9.2 & -- & 5 & 7 \\
\hline $25 \mathrm{~S}-02 \mathrm{~W}-17 \mathrm{ABB}^{3}$ & $08-14-85$ & 45 & 300 & 94 & 77 & 220 & 97 & 110 & 530 & 9.5 & .70 & 25 & 8 \\
\hline $25 S-02 W-22 B^{2} A^{2}$ & $07-29-80$ & - & 390 & 120 & 120 & 280 & 110 & 200 & 770 & 7.0 & .60 & $<8$ & $<3$ \\
\hline $25 \mathrm{~S}-02 \mathrm{~W}-22 \mathrm{DAA}^{2}$ & $07-29-80$ & -- & 340 & 100 & 110 & 270 & 89 & 160 & 670 & 7.5 & .69 & $<8$ & $<3$ \\
\hline $25 S-02 W-36 A_{B B}^{2}$ & $07-29-80$ & -- & 520 & 160 & 270 & 270 & 220 & 480 & 1,330 & 2.0 & .56 & 20 & 4 \\
\hline $25 S-03 \omega-02 B_{B C}^{3}$ & $08-14-85$ & 52 & 330 & 100 & 88 & 340 & 110 & 89 & 600 & 1.6 & -- & 350 & 110 \\
\hline $25 \mathrm{~S}-03 \mathrm{~W}-02 \mathrm{CCB}^{2}$ & $07-29-80$ & -- & 290 & 88 & 72 & 240 & 62 & 100 & 520 & 11 & - & $<8$ & $<3$ \\
\hline $25 s-03 w-03 D^{2}$ & $07-29-80$ & -- & 230 & 66 & 120 & 280 & 65 & 130 & 560 & 1.3 & .92 & $<8$ & 64 \\
\hline $25 S-03 w-05 \mathrm{BAB}^{3}$ & $08-14-85$ & 80 & 190 & 57 & 140 & 240 & 80 & 200 & 630 & 2.4 & .70 & 13 & 5 \\
\hline $25 S-03 w-06 A^{2}$ & $07-29-80$ & -- & 290 & 87 & 140 & 270 & 130 & 170 & 700 & 1.2 & .82 & $<8$ & 8 \\
\hline $25 s-03 w-11 C B D^{2}$ & $07-29-80$ & - & 430 & 130 & 170 & 340 & 200 & 220 & 940 & .25 & .77 & 1,000 & 780 \\
\hline
\end{tabular}

1 Sodium:chloride ratio computed if chloride concentration exceeded 100 milligrams per liter and if sodium and chloride data were available. The sodium:chloride ratio is dimensionless.

2 Data from Hathaway and others, 1981.

3 Data from files of U.S. Geological Survey (1980-85).

4 Data from Burrton Task Force (1984). 
Permian rocks in Reno and Stafford Counties, from salt-production activities at Lyons and Hutchinson, and from past oilfield activities. The Arkansas River alluvium contains sodium chloride type water in a narrow band that is generally less than 2 miles wide along both sides of the river and serves as a line source of sodium chloride water to adjacent unconsolidated deposits. The Burrton oilfield, which is located north and west of Burrton, is a source of sodium chloride ground water from oilfield activities, primarily the past disposal of brine in shallow evaporation pits that leaked and early attempts at pressurized disposal of brine in shallow injection wells.

Geochemical evidence based on sodium:chloride, bromide:chloride, and sulfate:chloride ratios indicates that the main source of salinity in the Burrton area is oilfield brine (Whittemore and Basel, 1982). Iodide:chloride ratios were interpreted to suggest that the saltwater originated at the surface and flowed downward through the freshwater aquifer, indicating that the shallow evaporation pits are the primary source of the oilfield brine (Burrton Task Force, 1984). The downward movement of brine in the Burrton area is illustrated in figure 21. Adjacent observation wells, located in township 23 south, range 3 west, section $21 \mathrm{CCC}$, are screened at depths of 38 and 64.5 feet. Large concentrations of chloride were first observed in the shallower well and then migrated downward to the deeper well, which now has larger concentrations of chloride than the shallower well.

Concentrations of chloride from table 17 are plotted on a map of the Wichita well-field area (fig. 22). In addition to large concentrations of chloride in the Burrton area, a band of sodium chloride water along the north side of the Arkansas River is also apparent. Sodium:chloride ratios shown in table 17 for wells with water having greater than $100 \mathrm{mg} / \mathrm{L}$ of chloride generally are less than 0.60 in the vicinity of Burrton, indicating contamination from oilfield brine, and greater than 0.60 in the area adjacent to the Arkansas River, indicating contamination by halite solution from Permian rocks upstream.

A two-dimensional solute-transport model was used to simulate the movement of chloride ions in this area (Spinazola and others, 1985). The model was used to project the effects of three rates of ground-water withdrawals (one-half of the 1971-79 withdrawal rate, the 1971-79 withdrawal rate, and two times the 1971-79 withdrawal rate) on the distribution of chloride concentrations. Results indicated that chloride concentrations would increase in direct proportion to projected withdrawal rates. Changes in chloride concentrations projected by withdrawal rates at one-half and equal to the 1971-79 rate were relatively small for the northern part of the well field that is affected by oilfield brine. However, the southern part of the well field experienced much greater increases in chloride concentrations for these withdrawal rates, indicating that the continuous line source of chloride from the Arkansas River will have a greater effect on increasing chloride concentrations in the well field than residual oilfield brines north and west of the well field. Lines of equal chloride concentration projected for ground-water-withdrawal rates of twice the 1971-79 rate are shown for 2020 in figure 22 (Spinazola and others, 1985).

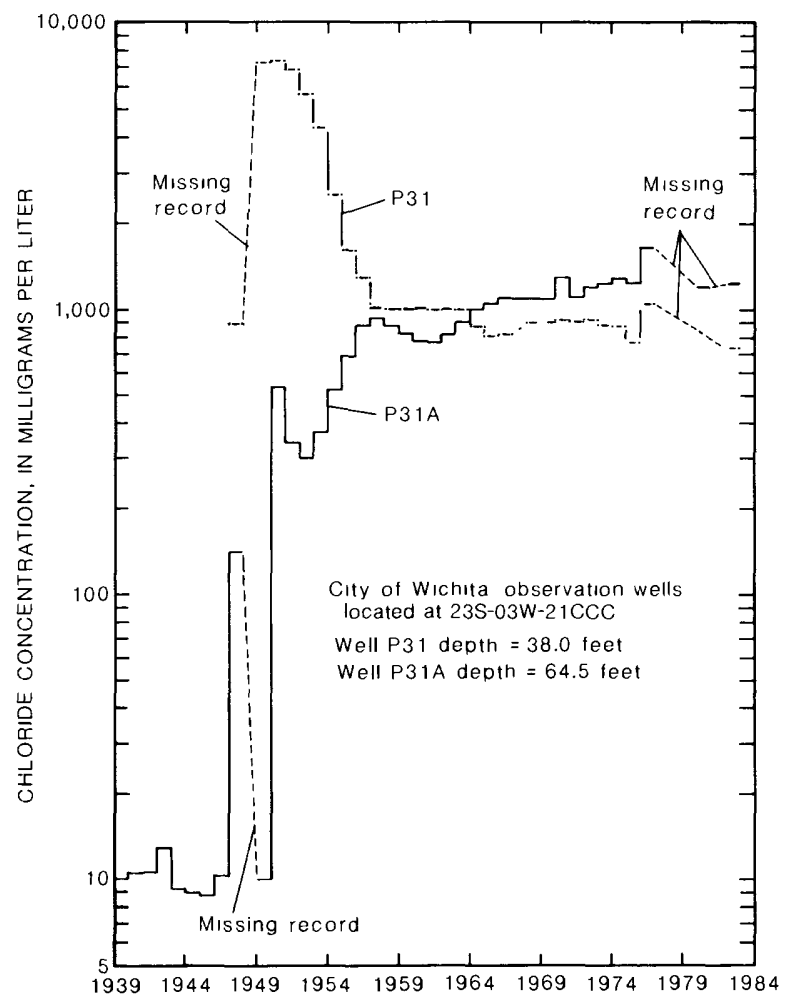

Figure 21. Chloride concentrations in adjacent wells indicating downward movement of brine from shallow evaporation pits in vicinity of Wichita well field, 1939-83. 


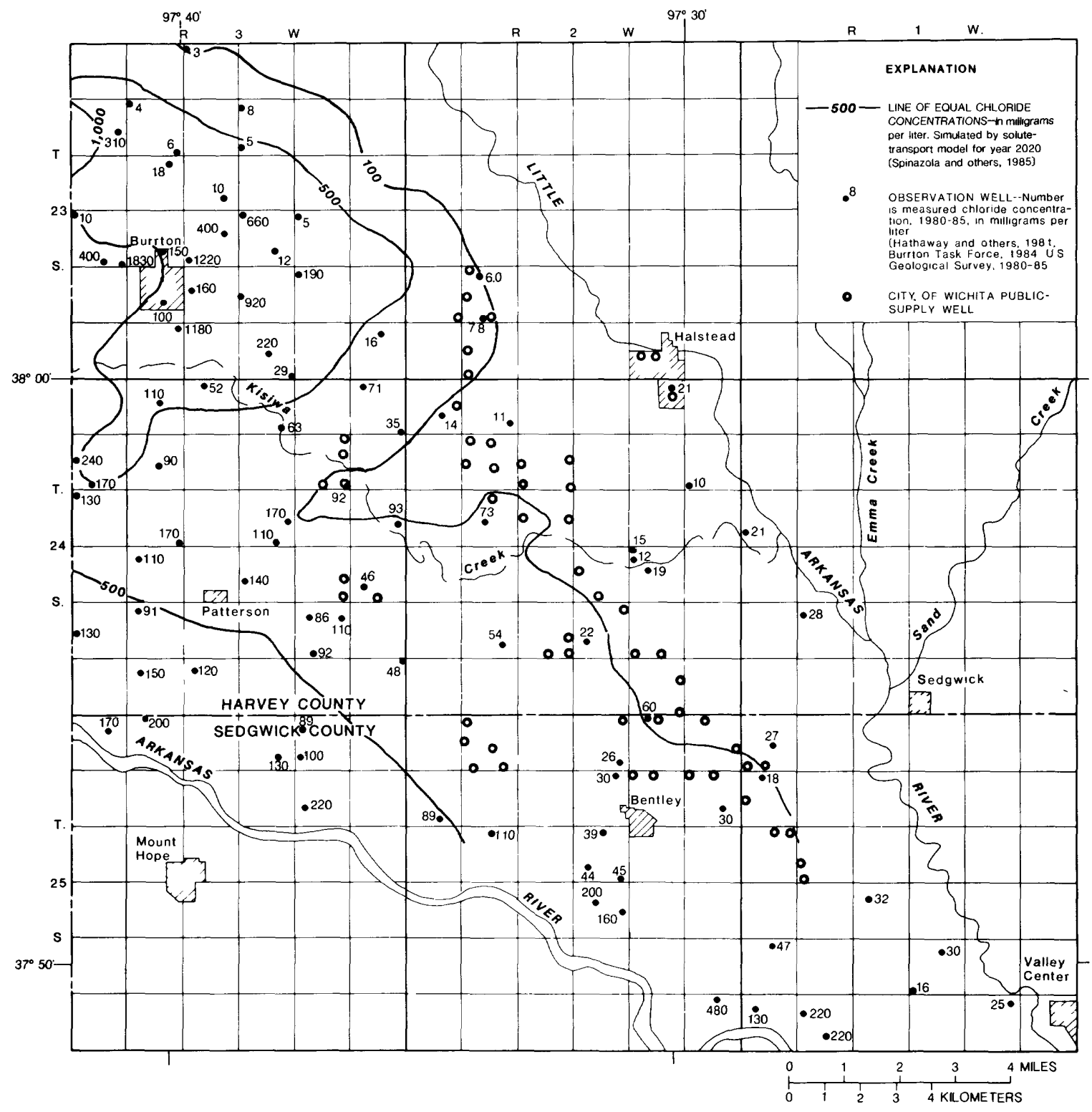

Figure 22. Chloride concentrations in vicinity of Wichita well field, 1980-85.

STREAM-AQUIFER INTERACTION IN ARKANSAS AND LITTLE ARKANSAS RIVER BASINS NEAR WICHITA

\section{Rationale for Evaluating Stream- Aquifer Interaction}

Unconsolidated valley-fill deposits that occur in the Arkansas and Little Arkansas River valleys north of Wichita are primary sources of ground water for public, irrigation, and industrial supplies. Although the rivers generally are not used as sources of water supplies, instream uses of water for wildlife habitat, recreation, and assimilation of municipal and industrial wastes are important; also, the rivers are potential sources of future water supplies.

A principal limiting factor in determining the suitability of rivers as sources of water supplies, or for selected instream uses, is the availability of base flow. The availability of base flow, or streamflow provided by ground-water discharge that sustains streamflow during periods of little or no surface runoff, is a function of both the hydrogeologic characteristics (hydraulic properties and extent) of the aquifer 
providing the base flow and the interaction between the stream and the aquifer.

Although digital models can be used to quantify stream-aquifer interaction, representative values of aquifer properties are needed to calibrate the models. Traditional methods of obtaining values of aquifer properties by pump or slug tests of wells generally are not applicable to definitions of stream-aquifer interaction because (1) the values represent only local conditions in the vicinity of the test wells and (2) stream-channel characteristics, such as depth and particle size of sediments forming the banks and bed, also affect stream-aquifer interaction. An alternative method for defining stream-aquifer interaction is based on the evaluation of base-flow recession.

A quantitative analytical method of determining stream-aquifer interaction by evaluating the slopes of selected base-flow recession curves was used to develop representative areal values of aquifer properties as they relate to stream-aquifer interaction in the Arkansas and Little Arkansas River valleys near Wichita.

\section{Definition of Selected Ground-Water Terms}

Ground-water terms used in the evaluation of stream-aquifer interaction are defined in the following paragraphs to aid in the understanding of the concepts presented (Lohman and others, 1972).

Hydraulic conductivity $(K)$--The volume of water at the existing viscosity that will move during a unit time under a unit hydraulic gradient through a unit area of the aquifer that is normal to the direction of flow, expressed in units of length per time (feet per day).

Hydraulic diffusivity (T/S)--The conductivity of the saturated aquifer when the unit volume of water moving horizontally is that involved in changing the hydraulic head a unit amount in a unit volume of aquifer, expressed in units of area per time (feet squared per day). In any isotropic homogeneous aquifer, the time involved for a given head change to occur at a particular point in response to a greater change in head at another point, such as an observation well affected by a pumping well, is inversely proportional to the hydraulic diffusivity of the aquifer.

Specific yield (Sy)--The volume of water an unconfined aquifer releases from or takes into storage per unit surface area of the aquifer per unit change in head, expressed as a dimensionless value. Specific yield is only an approximate measure of the relation between storage and hydraulic head in an unconfined aquifer because its definition implies that gravity drainage is complete.

Storage coefficient (S)--The volume of water released from or taken into storage per unit surface area of the aquifer per unit change in head,expressed as a dimensionless value. In an unconfined aquifer, the storage coefficient is virtually equal to the specific yield.

Transmissivity $(T)$--The rate at which water at the existing viscosity will move through a unit width of the aquifer under a unit hydraulic gradient, expressed in units of area per time (feet squared per day). Transmissivity is equal to an integration of hydraulic-conductivity values across the saturated part of the aquifer that is normal to the direction of flow and can be computed by multiplying the hydraulic conductivity by the saturated thickness.

\section{Relationship Between Stream- Aquifer Interaction and Base-Flow Recession}

The methodology used to define streamaquifer interaction by evaluating base-flow recessions of streams is based on an equation developed to determine the hydraulic diffusivity $(T / S)$ of an aquifer from the slope of a water-level recession in an observation well (Rorabaugh, 1960).

$$
\frac{T}{S}=\frac{0.933 a^{2} \log \left(h_{1}-h_{2}\right)}{t_{2}-t_{1}}
$$

where

$$
\begin{aligned}
& T=\begin{array}{l}
\text { transmissivity, in feet squared per } \\
\text { day; }
\end{array} \\
& S=\text { storage coefficient, dimensionless; }
\end{aligned}
$$


$a=$ half-width of the aquifer, in feet;

$h_{1}=$ initial water level, in feet, at time $t_{1}$, in days; and $h_{2}=\begin{aligned} & \text { water level, in feet, at time } t_{2} \text {, in } \\ & \text { days. }\end{aligned}$

Because base flow in a stream is provided by ground-water discharge, equation 2 can be modified to determine stream-aquifer interaction from the slope of a base-flow recession curve. After overland runoff has ceased and streamflow has declined to a point where it is being provided only by ground-water discharge, the base-flow recession curve will decline exponentially with time. If streamflow is plotted on a log scale and time on an arithmetic scale, the base-flow recession will plot as a straight line that declines through time. Furthermore, if the time required for base flow to decline exponentially through one log cycle is determined, equation 2 can be rewritten as (Rorabaugh and Simmons, 1966):

$$
\frac{T}{S}=\frac{a^{2}(0.933)}{\Delta t / \log \text { cycle }}
$$

where

$$
\begin{aligned}
& \Delta t / \log \text { cycle }=\text { the time required for the } \\
& \text { base flow to decline } \\
& \text { through one log cycle, in } \\
& \text { days; and } \\
& a=\quad \text { the aquifer half-width } \\
& \text { (which is equivalent to } \\
& \text { the average distance } \\
& \text { from the stream to the } \\
& \text { ground-water divides), } \\
& \text { in feet. }
\end{aligned}
$$

In order to apply equation 3 for the purpose of defining stream-aquifer interaction, it is necessary to determine slopes of base-flow recession curves that result from the interaction of the stream and aquifer and are not being affected by extraneous natural or humaninduced factors. Extraneous natural factors include runoff from precipitation or snowmelt and water loss by evapotranspiration or leakage. Extraneous human-induced factors include regulation by reservoirs, withdrawals of ground or surface water for water supplies, and return flows.

\section{Estimating Hydraulic Diffusivity}

Hydraulic diffusivity can be estimated from equation 3 if adequate streamflow records are available for determining the slope of the base-flow recession within the framework of required assumptions and if a reasonable value of the aquifer half-width can be determined. If periods of record are selected that are not affected by runoff, evapotranspiration, or human-induced factors and the base flow declines exponentially with time, forming a straight line on semilog graph paper, the required assumptions have been met. If the aquifer is leaky, the recession will not decline as a straight line, but the slope will increase with time, and the curve will bend downward.

\section{Determining Slope of Base-Flow Recession}

Proper selection of streamflow records can eliminate the effects of natural and humaninduced extraneous factors on base-flow recession. Streamflow regulation by reservoirs is not a factor in the area because the only reservoirs in the Arkansas River basin upstream from Wichita are in Colorado, and the Little Arkansas River basin has no large reservoirs. Small scattered ponds and lakes have little effect on base flow. Effects of runoff were avoided by examining climatological records in the area to determine that significant precipitation or snowmelt had not occurred during the base-flow recessions. Effects of irrigation (withdrawals and return flows) and evapotranspiration were avoided by evaluating base-flow recessions that occurred during periods of record prior to largescale development of irrigation and during the nongrowing season.

Effects of withdrawals for industrial and municipal supplies and subsequent return flows were harder to avoid because they had been occurring for a long time in the vicinity of Wichita and are not seasonal. Records of streamflow-gaging stations in Wichita and Derby were not used because of these effects.

Periods of streamflow for the Arkansas River near Hutchinson and the Little Arkansas River at Valley Center were adequate for 
analysis. Streamflow records for the Arkansas River near Hutchinson were evaluated from the beginning of record (1959) through 1965. Irrigation in the area increased rapidly after 1965 , so streamflow records after 1965 were avoided. There probably is a slight effect on the base-flow recessions caused by sewage-treatment plant effluent from Hutchinson and other upstream municipalities. However, these towns are not large, and the slopes of recessions that were examined did not appear to be affected significantly. Streamflow records for the Little Arkansas River at Valley Center were evaluated from the beginning of record (1921) through 1939. The Wichita well field began operation in 1940 and probably affects base-flow recession. Sedgwick and a few other small towns discharge sewage-treatment plant effluent into the Little Arkansas River, but the effects are minimal.

Analysis of base-flow recessions during periods of record selected according to guidelines presented in the preceding discussion determined that the slopes of the base-flow recessions were approximately 750 days per log cycle for the Arkansas River near Hutchinson and 1,000 days per log cycle for the Little Arkansas River at Valley Center. Although these values appear to be very large, it should be remembered that they represent base-flow recessions that result only from interaction between the streams and their aquifers and are not affected by extraneous natural or humaninduced factors. The lesser slope of the base-flow recession in the Little Arkansas River is due primarily to the deeper channel of that stream compared to the Arkansas River.

\section{Determining Aquifer Half-Width}

The aquifer half-width, or average distance from the stream to the ground-water divide, was determined for the Arkansas and Little Arkansas Rivers from water-level maps for the periods of streamflow record that were analyzed. The unconsolidated aquifer of the Arkansas River near Hutchinson was delineated from a map showing water-level contours in the High Plains aquifer during 1965 (Pabst and Stullken, 1982). The upstream extent of the Arkansas River unconsolidated aquifer was determined to be at Garden City, about 200 miles west of Wichita, where it became a gaining stream, as indicated by the water-level contours. The width of the Arkansas River unconsolidated aquifer was limited either to ground-water divides shown by the water-level contours, to points where the saturated thickness approaches zero, or to the extent of the unconsolidated deposits (also shown on the water-level map).

The unconsolidated aquifer of the Little Arkansas River at Valley Center was delineated from a map showing pre-1950 water levels in the High Plains aquifer (Stullken and Pabst, 1982). The upstream extent of the Little Arkansas River unconsolidated aquifer was determined to be about 6 miles northeast of Hutchinson where the saturated thickness approaches zero. The aquifer width was limited either to ground-water divides, as shown by water-level contours, to points where the saturated thickness approaches zero, or to the extent of the unconsolidated deposits.

Measurements of the aquifer widths, at right angles to the streams, were made at regular intervals along the unconsolidated stream aquifers. The average half-width $(a)$ of the Arkansas River unconsolidated aquifer was determined to be about 37,000 feet, and the average half-width of the Little Arkansas River unconsolidated aquifer was determined to be about 50,000 feet. The greater width of the Little Arkansas River unconsolidated aquifer is caused by the inclusion of Equus beds aquifer in Harvey and southern McPherson Counties.

\section{Computation of Hydraulic Diffusivity}

Hydraulic diffusivity was computed by entering values of the base-flow recession slopes and aquifer half-widths determined in the preceding sections into equation 3 . The computed hydraulic diffusivity is approximately $1.6 \times 10^{6}$ feet squared per day for the unconsolidated aquifer of the Arkansas River near Hutchinson and $2.2 \times 10^{6}$ feet squared per day for the unconsolidated aquifer of the Little Arkansas River at Valley Center. The greater hydraulic diffusivity for the Little Arkansas River unconsolidated aquifer is primarily the result of its greater aquifer half-width. 
Comparison of Stream-Aquifer Properties with Aquifer Properties Determined by Previous Investigations

Values of transmissivity, storage coefficient, and hydraulic diffusivity for unconsolidated aquifers of the Arkansas and Little Arkansas River that were determined by previous investigations or developed from information provided by previous investigations are presented in table 18. Williams and Lohman (1949) determined values of transmissibility, an obsolete term, for 25 selected wells in the Wichita well field. The transmissibility values were converted to transmissivity (divided by 7.48 ) and ranged from 6,100 to 44,000 feet squared per day. Specific-yield values provided by Williams and Lohman were determined by laboratory tests of core samples from test holes. These specific-yield values were assumed to be equivalent to storage coefficients and ranged from 0.08 to 0.38 . The range of hydraulic diffusivity values shown by Williams and Lohman (1.6 $\times 10^{4}$ to $5.5 \times 10^{5}$ feet squared per day) was computed by dividing the minimum transmissivity by the maximum storage coefficient and vice versa.

Values of transmissibility shown on a map of Sedgwick County by Lane and Miller (1965a) were determined from permeability values obtained from pump tests in conjunction with sand and gravel thickness determined from well logs. The transmissibility values were converted to transmissivity, which ranged from 3,300 to 33,000 feet squared per day. The transmissivity values were divided by an average value of specific yield (0.20), assumed to be equivalent to the storage coefficient given in the text, to compute the range of hydraulic diffusivity shown ( $1.6 \times 10^{4}$ to $1.6 \times 10^{5}$ feet squared per day).

Values of transmissivity and storage coefficient presented by Reed and Burnett (1985) were determined by pump tests in unconsolidated aquifers of the Arkansas and Little Arkansas Rivers in Reno, Harvey, and Sedgwick Counties although some of the storage coefficients were estimated. The very small minimum storage coefficient $(0.0004)$ represents confined conditions in deeper parts of the aquifers. The range in hydraulic-diffusivity values $\left(4.1 \times 10^{4}\right.$ to $4.2 \times 10^{7}$ feet squared per day) represents actual observed values because the storage-coefficient $(0.0004$ to 0.16$)$ and transmissivity $(4,900$ to 34,000 feet squared per day) values were from the same pump tests.

Spinazola and others (1985) presented maps of hydraulic conductivity and saturated thickness. Transmissivity values ranging from 500 to 200,000 feet squared per day were determined from these maps. The transmissivity values then were divided by an average value of specific yield presented in the text $(0.15)$ that was assumed to be equal to the storage coefficient. The range in hydraulic diffusivity $\left(2.5 \times 10^{3}\right.$ to $1.3 \times 10^{6}$ feet squared per day) was estimated by dividing the minimum and maximum transmissivity values by the average storage coefficient.

Values of hydraulic diffusivity estimated by stream-aquifer interaction in the Arkansas River valley $\left(1.6 \times 10^{6}\right.$ feet squared per day) and the Little Arkansas River valley $\left(2.2 \times 10^{6}\right.$ feet squared per day) are within the range of those shown in table 18 but are larger than most. This could be because many of the wells on which pump tests were performed (Williams and Lohman, 1949) were deep, 200 feet or greater, and were screened at the bottom where deposits in the area are of Pleistocene and Late Pliocene age and are less permeable than the Holocene alluvium adjacent to the river (Lane and Miller, 1965a). If an average storage coefficient of 0.15 is assumed, the stream-aquifer transmissivity ranges from 240,000 feet squared per day in the Arkansas River valley to 330,000 feet squared per day in the Little Arkansas River valley. These values and the hydraulic diffusivity are reasonably close to the maximum values determined from data used in modeling groundwater flow (Spinazola and others, 1985).

\section{SUMMARY AND CONCLUSIONS}

The study area, which includes Sedgwick County and Wichita, has a large population and diverse economy. Most of the population and economic activity are centered in Wichita, the largest city in the State. Personal income is derived primarily from private, nonfarm activities that include manufacturing (fabricated metal, machinery, aircraft, food products, chemicals, and petroleum products), trade, and service industries. However, agricultural 
Table 18. Values of transmissivity (T), storage coefficient (S), and hydraulic diffusivity (T/S) for unconsolidated aquifers of the Arkansas and Little Arkansas Rivers in Reno, Harvey, and Sedgwick Counties, compiled from previous investigations

\begin{tabular}{|c|c|c|c|c|c|c|}
\hline \multirow[t]{2}{*}{ Source of data } & \multicolumn{2}{|c|}{$\begin{array}{c}\mathrm{T} \text {, in feet squared } \\
\text { per day }\end{array}$} & \multicolumn{2}{|c|}{ s, dimens ionl ess } & \multicolumn{2}{|c|}{$\begin{array}{c}\mathrm{T} / \mathrm{S} \text {, in feet squared } \\
\text { per day }\end{array}$} \\
\hline & Minimum & Maximum & Minimum & Maximum & Minimum & Maximum \\
\hline Will iams and Lohman, 19491 & 6,100 & 44,000 & 0.08 & 0.38 & $1.6 \times 10^{4}$ & $5.5 \times 10^{5}$ \\
\hline Lane and Miller, $1965 \mathrm{a}^{2}$ & 3,300 & 33,000 & .20 & .20 & $1.6 \times 10^{4}$ & $1.6 \times 10^{5}$ \\
\hline Reed and Burnett, $1985^{3}$ & 4,900 & 34,000 & .0004 & .16 & $4.1 \times 10^{4}$ & $4.2 \times 10^{7}$ \\
\hline Spinazola and others, $1985^{4}$ & 500 & 200,000 & .15 & .15 & $2.5 \times 10^{3}$ & $1.3 \times 10^{6}$ \\
\hline
\end{tabular}

1 Values of transmissibility, an obsolete term, were converted to transmissivity, and values of specific yleld were assumed to be virtually equal to the storage coefficient, as is the case in an unconfined aquifer. Values of transmissibil ity had been determined by pump tests, and specific yields were determined by laboratory analysis of core samples. Maximum hydraulic diffusivity was estimated by dividing maximum observed $T$ by minimum observed S, and minimum hydraulic diffusivity was estimated by dividing minimum $T$ by maximum $\mathrm{S}$.

2 values of transmissibility were determined from a map in the report and converted to transmissivity. An average specific-yield value given in the report was assumed to be virtually equal to the storage coefficient. Maximum hydraulic diffusivity was estimated by dividing the maximum observed $T$ by the average $S$, and minimum hydraulic diffustuity was estimated by dividing minimum observed $\mathrm{T}$ by the average $\mathrm{S}$.

3 These values represent results of pump tests used to determine $T$ and $S$. In some cases, $S$ values were estimated.

4 Transmissivity was estimated from maps showing hydraulic conductivity and saturated thickness. The storage coefficient is equivalent to an average specific yield presented in the report. Maximum hydraul ic diffusivity was estimated by dividing maximum $T$ by average $S$, and minimum hydraul ic diffusivity was estimated by dividing minimum $T$ by average $S$. 
activities are also important as the Sedgwick County ranked first in the State in number of farms, third in acres harvested, and 10th in crop value during 1984. During 1985 , about 45,000 acres were irrigated. The large population and diverse economy of the study area need adequate water supplies.

During 1985, an estimated 134,200 acrefeet of water were used for public supplies (42 percent), irrigation (40 percent), self-supplied industrial use (14 percent), and self-supplied domestic use (4 percent). About 84 percent of the water used was ground water. The city of Wichita, which has annual water-rights appropriations of 40,000 acre-feet from a well field in the Equus beds aquifer, 17,900 acre-feet from a local well field, and 52,600 acre-feet from Cheney Reservoir, used 53,500 acre-feet of water during 1985 . If the city could fully utilize these existing water rights, public supplies should meet demand until at least 2015.

The Arkansas, Little Arkansas, North Fork Ninnescah, South Fork Ninnescah, and Ninnescah Rivers are the principal streams in the county. Streamflow in the area is directly related to cumulative departure from average precipitation, except for the Ninnescah and North Fork Ninnescah Rivers which are regulated by Cheney Reservoir. In recent years (1975-85), precipitation and streamflow have been near average, except for the Arkansas River where streamflow has declined since 1980 , possibly because of increased irrigation or other agricultural practices such as terracing. The streams are sustained by ground-water discharge during times of little or no surface runoff, except for the North Fork Ninnescah River upstream of Cheney Reservoir, which flows primarily in response to surface runoff, and the North Fork Ninnescah River downstream from Cheney Reservoir, which is controlled by the reservoir. Streamflow in the Ninnescah River has been decreased by Cheney Reservoir.

The Arkansas River is in approximate equilibrium with the ground water in the valleyfill deposits north of Wichita but becomes a gaining stream at Wichita. The Little Arkansas and Ninnescah Rivers are gaining streams through the county. However, effects of groundwater withdrawals for public and industrial supplies have decreased gains in localized reaches.

Water in the Arkansas River is a sodium chloride type, with a median dissolved-solids concentration of $1,700 \mathrm{mg} / \mathrm{L}$ at Hutchinson and $1,200 \mathrm{mg} / \mathrm{L}$ at Derby. The Little Arkansas River has a calcium bicarbonate type water, with a median dissolved-solids concentration of $\mathbf{4 8 0}$ $\mathrm{mg} / \mathrm{L}$. The North Fork Ninnescah, South Fork Ninnescah, and Ninnescah Rivers have a sodium chloride type water, with median dissolvedsolids concentrations ranging from $590 \mathrm{mg} / \mathrm{L}$ for the North Fork Ninnescah River at Cheney Dam to $760 \mathrm{mg} / \mathrm{L}$ for the South Fork Ninnescah River near Murdock. The source of sodium and chloride in the Arkansas, North Fork Ninnescah, South Fork Ninnescah, and Ninnescah Rivers is ground water from Permian rocks west of Sedgwick County. Concentrations of principal dissolved constituents in the streams are inversely related to streamflow rates, whereas the concentration of suspended sediment is directly related to streamflow rate.

Chemical and physical erosion rates in major stream basins were estimated from annual loads of dissolved solids and suspended sediment. The Arkansas River basin upstream of Hutchinson has the smallest annual rate of chemical erosion (16.8 tons dissolved solids per square mile) and physical erosion (12.8 tons suspended sediment per square mile). The South Fork Ninnescah River has the largest annual rate of chemical erosion, 206 tons dissolved solids per square mile. The Little Arkansas River has the largest annual rate of physical erosion, 239 tons suspended sediment per square mile.

A low-flow seepage and water-quality survey of area streams was conducted in March 1985. The data indicate that the Arkansas River was losing water in its reaches between 4 miles east of Maize and 21st Street in Wichita and between Derby and Mulvane, possibly because of nearby ground-water withdrawals for industrial and public supplies. Water in the Arkansas River was a sodium chloride type, and concentrations of dissolved solids decreased through the county from $1,800 \mathrm{mg} / \mathrm{L}$ near Mount Hope to $1,000 \mathrm{mg} / \mathrm{L}$ at Mulvane. The Little Arkansas River gained water in the reach from the town of Sedgwick to its confluence with the Arkansas River in Wichita. Concentrations of 
dissolved solids increased slightly from $350 \mathrm{mg} / \mathrm{L}$ near Sedgwick to $400 \mathrm{mg} / \mathrm{L}$ at $37 \mathrm{th}$ Street in Wichita. The increase in dissolved solids was caused by sodium chloride water from the Arkansas River moving through the alluvium and into the Little Arkansas River in north Wichita. Water in the Little Arkansas River was a calcium bicarbonate type, except near its confluence with the Arkansas River where it was a mixed calcium sodium bicarbonate chloride type.

The Ninnescah River generally gained streamflow, and concentrations of dissolved solids decreased through the county (water was not being released from Cheney Reservoir), except between Kansas Highway 42 and Clearwater, where streamflow and concentrations of dissolved solids remained constant. Large withdrawals of ground water for industrial supplies west of Clearwater could have caused a local loss of streamflow. Water in the Ninnescah River is a sodium chloride type.

Small streams draining the area generally had water-quality characteristics that were related to the rock types that provided base flow. Streams draining the Wellington Formation, where it occurs at or near the surface east of the Arkansas River, commonly had calcium sulfate type water, with concentrations of dissolved solids greater than $1,000 \mathrm{mg} / \mathrm{L}$. However, small tributary streams to the Little Arkansas River generally had calcium bicarbonate type water, with less than $500 \mathrm{mg} / \mathrm{L}$ dissolved solids. Streams draining the uplands between the Arkansas and Ninnescah Rivers, where the Ninnescah Shale and Wellington Formation are overlain by lower Pleistocene (undifferentiated pre-Illinoian age) deposits, and (or) loess and colluvium, generally had calcium bicarbonate type water, with less than $500 \mathrm{mg} / \mathrm{L}$ dissolved solids. In the vicinity of the Wichita-Valley Center floodway in west Wichita, water in small streams became a mixed type as sodium chloride type water from the Arkansas River alluvium was gained. Small streams draining the southwest corner of the county, where the Ninnescah Shale is overlain by colluvium, had mixed-ion type water, with less than $1,000 \mathrm{mg} / \mathrm{L}$ dissolved solids.

Sewage-treatment plant effluent resulted in increased concentrations of ammonia as nitrogen in the Arkansas River at Derby (1.70 $\mathrm{mg} / \mathrm{L})$ and Mulvane $(1.5 \mathrm{mg} / \mathrm{L})$, in the Little Arkansas River near Sedgwick $(0.62 \mathrm{mg} / \mathrm{L})$, in Cowskin Creek near Maize $(0.74 \mathrm{mg} / \mathrm{L})$ and at the Sumner County line $(1.20 \mathrm{mg} / \mathrm{L})$, and in West Fork Chisholm Creek near Park City (0.39 $\mathrm{mg} / \mathrm{L}$ ). Evidence of contamination by oilfield brine was detected in the Wichita-Valley Center floodway near Haysville, Prairie Creek 4 miles southeast of Furley, and Whitewater Creek at the Butler County line.

Water-quality data were collected from 14 selected impoundments during October 1985. About two weeks prior to sampling, a large storm had produced considerable runoff, and the impoundments were relatively full. Those in upland areas were turbid and generally had calcium bicarbonate type water, with very small concentrations of dissolved solids, generally less than $100 \mathrm{mg} / \mathrm{L}$. However, agricultural pesticides (atrazine, cyanazine, propazine, and a degradation product, heptachlor epoxide) were detected in 8 of the 14 impoundments. Three sandpit impoundments near the Arkansas River were relatively clear because they receive little runoff and contain primarily ground water. However, they contained sodium chloride type water, with concentrations of dissolved solids ranging from 630 to $1,300 \mathrm{mg} / \mathrm{L}$.

Water-quality characteristics of hypothetical impoundments on the Little Arkansas River at Valley Center and the South Fork Ninnescah River near Murdock were estimated from stream data. An impoundment on the Little Arkansas River would have water with a mean dissolved-solids concentration of about $220 \mathrm{mg} / \mathrm{L}$ and would lose about 160 to 310 acre-feet of storage per year to sedimentation. An impoundment on the South Fork Ninnescah River would have water with a mean dissolvedsolids concentration of about $560 \mathrm{mg} / \mathrm{L}$ and would lose about 59 to 110 acre-feet of storage per year to sedimentation.

Cheney Reservoir contains water that is a sodium chloride type and has a mean dissolvedsolids concentration of about $500 \mathrm{mg} / \mathrm{L}$. The reservoir has lost approximately 290 to 530 acrefeet of storage due to sedimentation during 1964 through 1986. During 1985, the city of Wichita withdrew 18,300 acre-feet of water from Cheney Reservoir for public supplies. From 1966 
through 1985, Wichita has withdrawn a total of 322,610 acre-feet of water from Cheney Reservoir.

Ground water occurs throughout the study area. The principal aquifer is unconsolidated deposits in the Arkansas River valley that are locally more than 200 feet thick and can yield as much as 2,000 gallons per minute to wells. Unconsolidated deposits in the Ninnescah River valley are thinner, less permeable, and yield less than 500 gallons per minute. Wells in the undifferentiated pre-Illinoian deposits on uplands north of the Ninnescah River yield as much as 50 gallons per minute. Wells in the Ninnescah Shale generally yield less than 10 gallons per minute, as do wells in the Wellington Formation, except when gypsum or anhydrite solution channels are encountered and yields of as much as 350 gallons per minute can be obtained.

Ground water in the county generally moves from upland areas towards streams. In the Arkansas River valley north of Wichita, the ground water moves in the same direction and with the same gradient as the Arkansas River. South of Wichita, ground water moves toward the Arkansas River, as it does in the Little Arkansas River and Ninnescah River valleys. In several areas of the county, particularly in the vicinity of the Wichita well field, ground-water withdrawals have caused cones of depression to form. Upstream from its confluence with the Arkansas River, a low-head dam on the Little Arkansas River has caused the formation of a ground-water mound. With the exception of the Wichita well field, effects of ground-water withdrawals on water levels are minor and localized. Ground-water levels are closely related to cumulative departure from average precipitation.

Ground-water recharge in the area primarily occurs from precipitation and is estimated to average from 0.1 to 8.8 inches per year, depending on local conditions. Approximately 2.88 million acre-feet of water with less than $1,000 \mathrm{mg} / \mathrm{L}$ dissolved solids are stored in unconsolidated deposits of the Arkansas, Little Arkansas, and Ninnescah River valleys in Sedgwick County. Ground-water discharge occurs principally through gaining streams (the Arkansas River south of Wichita, the Little Arkansas River, and the Ninnescah River) and is estimated to be about 148,000 acrefeet per year. Ground-water discharge caused by well withdrawals was estimated to be about 112,700 acre-feet during 1985 . The maximum rate of ground-water loss through evapotranspiration is estimated to be 3.5 inches per year. However, evapotranspiration from the saturated zone generally occurs only when the depth to water is less than 10 feet.

Analyses of water-quality data collected from 101 wells in Sedgwick County demonstrate the close relationship between geology and water-quality characteristics and indicate some of the potential sources of contamination in the area.

Water from wells in the Wellington Formation commonly is a calcium sulfate type, with more than $1,000 \mathrm{mg} / \mathrm{L}$ dissolved solids. The calcium and sulfate are derived primarily from the dissolution of gypsum and anhydrite. Hardness as calcium carbonate commonly approaches or exceeds $1,000 \mathrm{mg} / \mathrm{L}$ (primarily as noncarbonate hardness). Water from wells in the Ninnescah Shale is less mineralized and generally has less than $1,000 \mathrm{mg} / \mathrm{L}$ dissolved solids because the shale contains less soluble minerals. Dissolved-solids concentrations in water from wells completed in bedrock generally increase with depth because duration of contact between the water and minerals increases. Unconsolidated deposits generally yield calcium bicarbonate water, with less than $500 \mathrm{mg} / \mathrm{L}$ dissolved solids, except alluvium adjacent to the Arkansas River north of Wichita where sodium chloride water with more than $1,000 \mathrm{mg} / \mathrm{L}$ dissolved solids occurs. Unconsolidated deposits are erosional remnants with few soluble minerals. However, they are more susceptible to contamination from surface sources, such as infiltration of saline water from the Arkansas River north of Wichita.

Ground-water contamination by oilfield brine was indicated in water from 16 wells sampled in the county. These wells generally are in areas of past or present oilfield activities, such as the Gladys oilfield in southern Wichita. Concentrations of nitrite plus nitrate as nitrogen were greater than $10 \mathrm{mg} / \mathrm{L}$ in ground water from about 10 percent of the wells sampled. These wells are scattered randomly throughout the 
county, and the large concentrations probably result from local contamination (surface runoff or infiltration of nitrogen fertilizer, septic fields, or animal wastes). Iron concentrations exceeding $300 \mu \mathrm{g} / \mathrm{L}$ were detected in water from 18 wells. Most of the large concentrations of iron probably can be attributed to corroded steel or galvanized well casings. Manganese concentrations exceeding $50 \mu \mathrm{g} / \mathrm{L}$ were detected in water from 31 wells. All but one of the wells are completed in alluvium or terrace deposits, indicating that the source of manganese probably is organic material in the soil. Herbicides (atrazine, metolachlor, propazine, and simazine) were detected in water from 5 of the 19 wells from which water samples were collected for herbicide analysis. Although none of the herbicides exceeded available U.S. Environmental Protection Agency health advisory levels, the occurrence of several herbicides in water from any well may cause synergistic effects. Volatile organic compounds were analyzed in water samples from only 10 wells. Trichloroethylene was detected in water from one well, but the concentration did not exceed the water-quality criterion. Several other areas in the county have local ground-water contamination caused by volatile organic compounds.

The city of Wichita withdrew about 35,200 acre-feet of water from the Wichita well field during 1985 . Since 1940 , the city has withdrawn a total of $1,268,400$ acre-feet of water from the well field. Earlier investigations estimated a perennial yield of 40,000 acre-feet from the well field, based on an average recharge by precipitation of about 6 inches per year. A recent ground-water modeling investigation indicates that average recharge by precipitation may be only about 3.25 inches, which would decrease the perennial yield to less than 30,000 acre-feet. Recent investigations using ground-water flow and solute-transport models predict that withdrawals at the 1971-79 rate (about 30,000 acre-feet per year) during 1980-2020 would have little effect on ground-water quality in the well field, but water levels would decline about 15 feet. Withdrawals at twice the 1971-79 rate during 1980-2020 would lower water levels an additional 40 feet and significantly increase chloride concentrations in the southern part of the well field. These models indicate that the continuous line source of sodium chloride water in the Arkansas River is a greater threat to the well field than brine contamination from the Burrton oilfield.
Analysis of base-flow recession curves was used to develop estimates of hydraulic diffusivity in the Arkansas River valley (1.6 x 106 feet squared per day) and the Little Arkansas River valley $\left(2.2 \times 10^{6}\right.$ feet squared per day). These hydraulic-diffusivity values are within the range of values determined by aquifer tests during previous investigations.

\section{REFERENCES CITED}

Brady, N.C., 1974, The nature and properties of soils, 8th ed.: New York, Macmillan Publishing Co., Inc., 639 p.

Burrton Task Force, 1984, Report to chief engineer-director of the Kansas State Board of Agriculture concerning the proposed Burrton intensive groundwater use control area: $103 \mathrm{p}$.

Carswell, W.J., Jr., 1982, Storage requirements to sustain gross reservoir outflow from small basins in Kansas: Kansas Water Office Technical Report 16, $40 \mathrm{p}$.

Eagleman, J.R., 1973, Visualization of climate: Lawrence, Kansas, Environmental Publications, $144 \mathrm{p}$.

Ellis, D.W., and others, 1963, Floods at Wichita, Kansas: U.S. Geological Survey Hydrologic Investigations Atlas HA-63, scale 1:24,000, 5 sheets.

Engineering Enterprises, Inc., 1982, South Wichita chloride study: Topeka, Interim Report, Phase I, for the Kansas Department of Health and Environment, $62 \mathrm{p}$.

Fromm, Carla, and Daley, Douglas, eds., 1986, Kansas water quality 1984-1986: Topeka, Kansas Department of Health and Environment Water Quality Assessment Report, 85 p.

Furness, L.W., 1962, Kansas streamflow characteristics, part 4--Storage requirements to sustain gross reservoir outflow: Kansas Water Resources Board Technical Report 4, $177 \mathrm{p}$. 
Gogel, Tony, 1981, Discharge of saltwater from Permian rocks to major stream-aquifer systems in central Kansas: Kansas Geological Survey Chemical Quality Series 9,60 p.

Green, D.W., and Pogge, E.C., 1977, Computer modeling of the Equus beds aquifer system in south-central Kansas: Lawrence, University of Kansas Center for Research, Inc., $53 \mathrm{p}$.

Hammond, E.H., 1964, Classes of land-surface form in the forty-eight States, in The National Atlas of the United States of America, 1970: Department of the Interior, U.S. Geological Survey, p. 62-63.

Hansen, C.V., 1987, Estimates of freshwater storage and potential natural recharge for principal aquifers in Kansas: U.S. Geological Survey Water-Resources Investigations Report 87-4230, 31 p., 4 plates.

Hargadine, Gerald, and Luehring, Jo Ann, 1978, Mineral intrusion in Kansas surface water--A summary and management report: Topeka, Kansas Department of Health and Environment, Kansas WaterQuality Management Plan 1978, 44 p.

Hart, R.J., and Spruill, T.B., 1988, Description and hydrogeologic evaluation of nine potential hazardous-waste sites in Kansas, 1984-86: U.S. Geological Survey Water-Resources Investigations Report 88-4015, 73 p.

Hathaway, L.R., Waugh, T.C., Galle, O.K., and Dickey, H.P., 1981, Chemical quality of irrigation waters in the Equus beds area, south-central Kansas: Kansas Geological Survey Chemical Quality Series 10,45 p.

James, I.C., II, 1967, Flood runoff from partially urbanized areas, Wichita, Kansas, Report No. 1--Analysis of initial conditions: Lawrence, Kansas, U.S. Geological Survey open-file report, $62 \mathrm{p}$.
Kansas State Board of Agriculture, 1986, Kansas farm facts 1986: Topeka, Kansas State Board of Agriculture, Division of Statistics, $110 \mathrm{p}$.

Lane, C.W., and Miller, D.E., 1965a, Geohydrology of Sedgwick County, Kansas: Kansas Geological Survey Bulletin 176, 100 p.

1965b, Logs of wells and test holes in Sedgwick County, Kansas: Kansas Geological Survey Special Distribution Publication $22,175 p$.

Lane, C.W., Reavis, E.L., and Stramel, G.J., 1962, Emergency water supplies in the Wichita area, Kansas: U.S. Geological Survey Hydrologic Investigations Atlas HA-58, scale 1:250,000, 1 sheet.

Leonard, R.B., and Kleinschmidt, M.K., 1976, Saline water in the Little Arkansas River basin area, south-central Kansas: Kansas Geological Survey Chemical Quality Series 3, 24 p.

Linsley, R.K., Jr., Kohler, M.A., and Paulhus, J.L.H., 1975, Hydrology for engineers, 2nd ed.: New York, McGraw-Hill, Series in Water Resources and Environmental Engineering, $487 \mathrm{p}$.

Lohman, S.W., and Frye, J.C., 1940, Geology and ground-water resources of the Equus beds area in south-central Kansas: Economic Geology, v. 35, no. 7, p. 839-866.

Lohman, S.W., and others, 1972, Definitions of selected ground-water terms--Revisions and conceptual refinements: U.S. Geological Survey Water-Supply Paper 1988, $21 \mathrm{p}$.

Lorenz, J.B., Gray, J.P., Hardten, R.D., and Gallagher, J.A., 1985, Report on condition and operation of the Wichita Water Utility, Wichita, Kansas: Kansas City, Missouri, Black and Veatch EngineersArchitects, unnumbered pages. 
Meinzer, O.E., 1914, Preliminary report on ground water for irrigation in the vicinity of Wichita, Kansas: U.S. Geological Survey Water-Supply Paper 345-A, p. 1-9.

Meister, R.T., and others, 1984, Farm chemicals handbook: Willoughby, Ohio, Meister Publishing Company, $520 \mathrm{p}$.

Murray, W.A., 1985, Kansas statistical abstract 1984-85: Lawrence, University of Kansas, Institute for Public Policy and Business Research, $258 \mathrm{p}$.

National Academy of Sciences and National Academy of Engineering, 1973, Water quality criteria 1972: U.S. Environmental Protection Agency Ecological Research Series, EPA/R3/73/033, March 1973, 594 p.

National Oceanic and Atmospheric Administration, 1888-1985, Climatological data, Kansas: Asheville, N.C., National Climatic Center, monthly reports.

Pabst, M.E., and Stullken L.E., 1982, Altitude and configuration of the water table in the High Plains aquifer in Kansas, 1965: U.S. Geological Survey Open-File Report 82449 , scale $1: 500,000,1$ sheet.

Parker, H.N., 1911, Quality of the water supplies of Kansas: U.S. Geological Survey WaterSupply Paper 273, p. 180-181 and 269-293.

Peek, C.O., and Jordan, P.R., 1978, Determination of peak discharge from rainfall data for urbanized basins, Wichita, Kansas: U.S. Geological Survey Open-File Report 78-974, 49 p.

Penner, H.L., and Wehmueller, W.A., 1979, Soil survey of Sedgwick County, Kansas: U.S. Department of Agriculture, Soil Conservation Service, $126 \mathrm{p}$.

Perry, C.A., and Hart, R. J., 1984, Flood-

frequency estimates for five gaged basins in Wichita, Kansas: U.S. Geological Survey Water-Resources Investigations Report 84-4038, 23 p.

Petri, L.R., Lane, C.W., and Furness, L.W., 1964, Water resources of the Wichita area,
Kansas: U.S. Geological Survey WaterSupply Paper 1499-I, 69 p.

Reed, T.B., and Burnett, R.D., 1985, Compilation and analyses of aquifer performance tests in eastern Kansas: U.S. Geological Survey Open- File Report 85-200, 125 p.

Richards, D.B., 1971, Flood runoff from partially urbanized areas, Wichita, Kansas, Report No. 2--Analysis of progressing conditions: Lawrence, Kansas, U.S. Geological Survey open-file report, $62 \mathrm{p}$.

Richards, D.B., and Dunaway, T.W., 1972, Geohydrologic data for numerical modeling of ground-water withdrawals in the Little Arkansas River basin area, south-central Kansas: Lawrence, Kansas, U.S. Geological Survey open-file report, $426 \mathrm{p}$.

Rorabaugh, M.I., 1960, Use of water levels in estimating aquifer constants in a finite aquifer: International Association of Scientific Hydrology Commission of Subterranean Waters, Publication 52, p. 314-323.

Rorabaugh, M.I., and Simmons, W.D., 1966, Exploration of methods relating ground water to surface water, Columbia River basin--Second phase: U.S. Geological Survey open-file report, $62 \mathrm{p}$.

Schoewe, W.H., 1949, The geography of Kansas, part 2--Physical geography: Transactions of the Kansas Academy of Sciences, v. 52, no. 3, p. 261-333.

Sophocleous, M.A., 1983, Water quality modeling of the Equus beds aquifer in south-central Kansas: Kansas Geological Survey Open-File Report 83-1, 75 p.

Sophocleous, M.A., and Perry, C.A., 1985, Experimental studies in natural groundwater-recharge dynamics--The analysis of observed recharge: Journal of Hydrology, v. 81, p. 297-332.

Spinazola, J.M., Gillespie, J.B., and Hart, R.J., 1985, Ground-water flow and solute transport in the Equus beds area, southcentral Kansas, 1940-79: U.S. Geological Survey Water-Resources Investigations Report 85-4336, 68 p. 
Stoner, J.D., 1985, Dissolved solids in the Arkansas River basin, in National Water Summary, 1984: U.S. Geological Survey Water-Supply Paper 2275, p. 79-84.

Stramel, G.J., 1956, Progress report on the ground-water hydrology of the Equus beds area, Kansas: Kansas Geological Survey Bulletin 119, Part 1, 59 p.

_1962a, A review of the geology and hydrology of the Wichita well field: City of Wichita Water Department, $29 \mathrm{p}$.

1962b, A preliminary review of artificial recharge potential in the area between Hutchinson and Wichita, Kansas: City of Wichita Water Department, 21 p.

1967, Progress report on the ground-water hydrology of the Equus beds area, Kansas--1966: Kansas Geological Survey Bulletin 187, Part 2, 27 p.

Stullken, L.E., and Pabst, M.E., 1982, Altitude and configuration of the water table in the High Plains aquifer of Kansas, pre-1950: U.S. Geological Survey Open-File Report 82-117, scale 1:500,000, 1 sheet.

U.S. Army Corps of Engineers, 1973, Kansas water resources development: Dallas, Texas, U.S. Army Corps of Engineers Southwestern Division, $57 \mathrm{p}$.

U.S. Environmental Protection Agency, 1977, Quality criteria for water 1976: U.S. Environmental Protection Agency, 256 p.

1986a, Quality criteria for water 1986: U.S. Environmental Protection Agency, EPA 440/5-86-001.

$1986 \mathrm{~b}$, Secondary maximum contaminant levels (section 143.3 of part 143, National secondary drinking-water regulations): U.S. Code of Federal Regulations, Title 40, Parts 100 to 149 , revised as of July 1 , 1986 , p. 587-590.

1986c, Maximum contaminant levels (subpart B of part 141, National interim primary drinking-water regulations): U.S. Code of Federal Regulations, Title 40, Parts 100 to 149 , revised as of July 1, 1986, p. 524-528.
U.S. Geological Survey, 1980, Water resources data for Kansas, volume 2--Arkansas River basin: U.S. Geological Survey Water Data Report KS-80-2, 340 p.

1985, Water resources data for Kansas, water year 1985: U.S. Geological Survey Water Data Report KS-85-1, 478 p.

U.S. Soil Conservation Service, 1967, Distribution of principal kinds of soils--Orders, suborders, and great groups, in The National Atlas of the United States of America, 1970: Department of the Interior, U.S. Geological Survey, p. 85-88.

U.S. Water Resources Council, 1981, Guidelines for determining flood frequency: Hydrology Committee, Water Resources Council Bulletin 17B, p. 12-15.

Whittemore, D.O., 1982, Identification of saltwater sources affecting ground-water in the Blood orchards area, Sedgwick County, Kansas: Kansas Geological Survey Open-File Report 82-9, 16 p.

1984, Geochemical identification of salinity sources, in Proceedings of the 1983 International Symposium on State-of-theArt Control of Salinity, July 13-15, 1983, Salt Lake City, Utah, Richard H. French, ed.: Boston, Massachusetts, Butterworth Publishers, p. 505-514.

Whittemore, D.O., and Basel, C.L., 1982, Identification of saltwater sources affecting groundwater in the Burrton area, Harvey County, Kansas, initial report: Kansas Geological Survey Open-File Report 82-5, $11 \mathrm{p}$.

Williams, C.C., and Lohman, S.W., 1947, Methods used in estimating the groundwater supply in the Wichita, Kansas well-field area: Trans- actions of the American Geophysical Union, v. 28, no. 1, p. 120-131.

1949, Geology and ground-water resources of a part of south-central Kansas, with special references to the Wichita municipal water supply: Kansas Geological Survey Bulletin 79, $455 \mathrm{p}$. 